Photodissociation Dynamics of Polyatomic Molecules

by

Zhao, Hequan

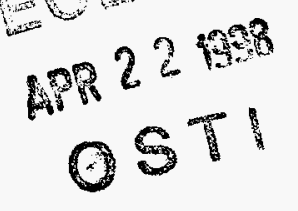

PHD Thesis submitted to Iowa state University

Ames Laboratory, U.S. DOE

Iowa state University

Ames, Iowa 50011

Date Transmitted: February 23, 1998

PREPARED FOR THE U.S. DEPARTMENT OF ENERGY

UNDER CONTRACT NO. W-7405-ENg-82.

DISTRIBUTION OF THIS DOCUMENT IS UNLMTED 


\section{DISCLAIMER}

This report was prepared as an account of work sponsored by an agency of the United States Government. Neither the United States Government nor any agency thereof, nor any of their employees, makes any warranty, express or implied, or assumes any legal liability or responsibility for the accuracy, completeness, or usefulness of any information, apparatus, product, or process disclosed, or represents that its use would not infringe privately owned rights. Reference herein to any specific commercial product, process, or service by trade name, trademark, manufacturer, or otherwise does not necessarily constitute or imply its endorsement, recommendation, or favoring by the United States Government or any agency thereof. The views and opinions of authors expressed herein do not necessarily state or reflect those of the United States Government or any agency thereof. 


\section{DISCLAIMER}

Portions of this document may be illegible electronic image products. Images are produced from the best available original document. 


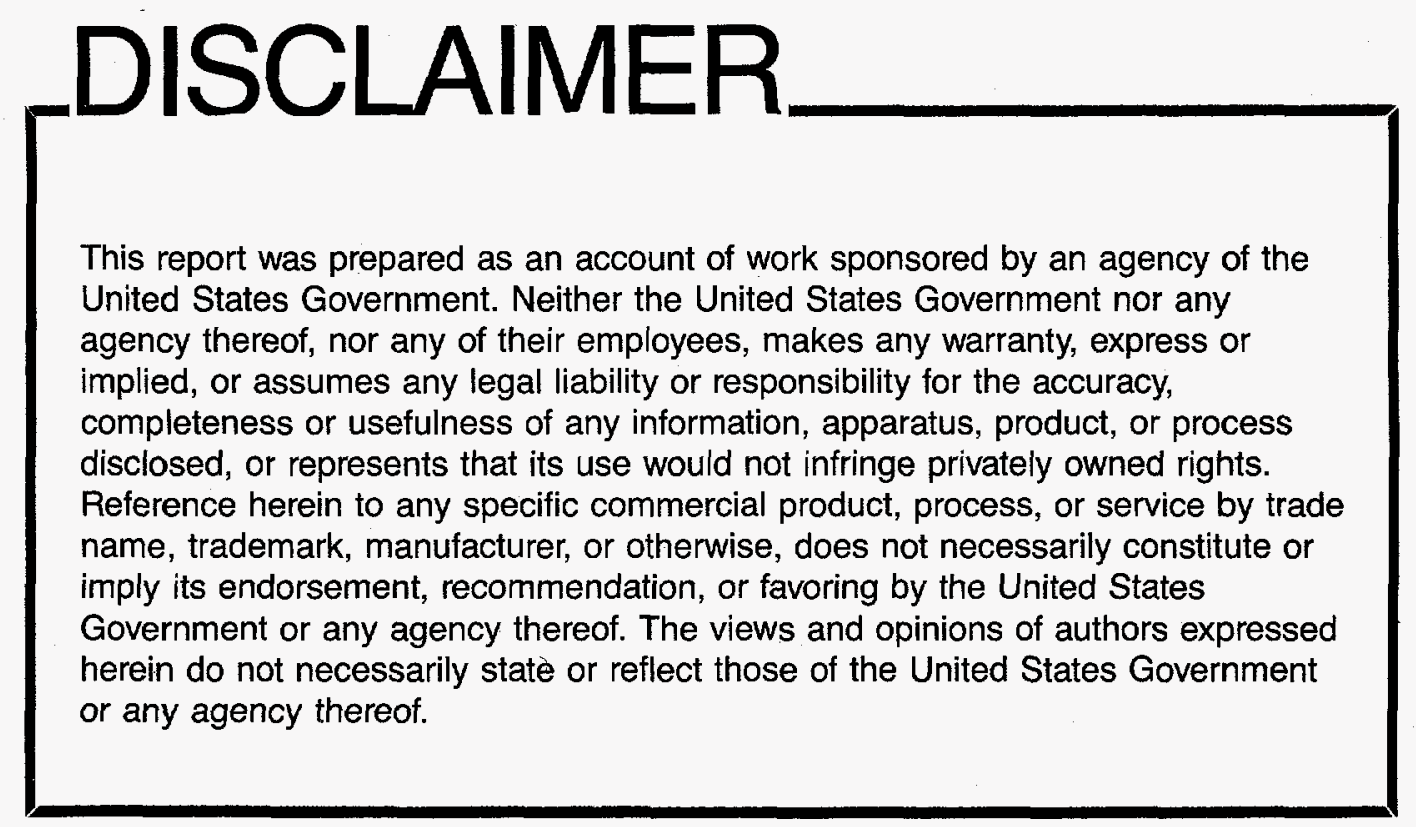

This report has been reproduced directly from the best available copy.

AVAILABILITY:

TO DOE and DOE contractors: Office of Scientific and Technical Information P.O. Box 62

Oak Ridge, TN 37831

prices available from: (615) $576-8401$

FTS: $626-8401$

To the public:

National Technical Information Service

U.S. Department of Commerce

5285 Port Royal Road

Springfield, VA 22161 


\title{
Photodissociation dynamics of polyatomic molecules
}

\author{
Hequan Zhao
}

\author{
Major Professor: Cheuk-Yiu Ng \\ Iowa State University
}

In the photodissociation of acetophenone $\left(\mathrm{C}_{6} \mathrm{H}_{5} \mathrm{COCH}_{3}\right)$ at $193 \mathrm{~nm}$, two major primary

processes, $\mathrm{C}_{6} \mathrm{H}_{5} \mathrm{COCH}_{3}+\mathrm{hv} \rightarrow \mathrm{C}_{6} \mathrm{H}_{5} \mathrm{CO}+\mathrm{CH}_{3}$ (process 1) and $\mathrm{C}_{6} \mathrm{H}_{5}+\mathrm{COCH}_{3}$ (process 2), are observed. Data analysis shows that excited $\mathrm{C}_{6} \mathrm{H}_{5} \mathrm{CO}$ and $\mathrm{CH}_{3} \mathrm{CO}$ thus formed further decompose, yielding secondary products $\mathrm{C}_{6} \mathrm{H}_{5}+\mathrm{CO}$ and $\mathrm{CH}_{3}+\mathrm{CO}$, respectively. For $248 \mathrm{~nm}$ excitation, the $\mathrm{C}_{6} \mathrm{H}_{5} \mathrm{CO}-\mathrm{CH}_{3}$ bond energy has been determined to be $80.2 \pm 3 \mathrm{kcal} / \mathrm{mol}$. Evidence is also found that the dissociation reaction $\mathrm{C}_{6} \mathrm{H}_{5} \mathrm{COCH}_{3}+\mathrm{hv} \rightarrow \mathrm{C}_{6} \mathrm{H}_{5} \mathrm{CH}_{3}+\mathrm{CO}$ occurs for excitation at both 193 and $248 \mathrm{~nm}$.

In the photodissociation of dimethylsulfoxide $\left[\left(\mathrm{CH}_{3}\right)_{2} \mathrm{SO}\right]$ at $193.3 \mathrm{~nm}$, in addition to $\mathrm{CH}_{3}$ and $\mathrm{SO}, \mathrm{CH}_{3} \mathrm{SO}$ is observed as a stable primary product, indicating that $\mathrm{CH}_{3} \mathrm{SO}+\mathrm{CH}_{3}$ is an important product process. Analysis of the TOF data provides evidence that SO is formed via a stepwise mechanism: $\left(\mathrm{CH}_{3}\right)_{2} \mathrm{SO}+\mathrm{hv}(193.3 \mathrm{~nm}) \rightarrow \mathrm{CH}_{3} \mathrm{SO}+\mathrm{CH}_{3} \rightarrow 2 \mathrm{CH}_{3}+$ SO.

In the photodissociation of $\mathrm{HSCH}_{2} \mathrm{CH}_{2} \mathrm{SH}$ at $193.3 \mathrm{~nm}$, on the basis of the observed maximum kinetic energy for the formation of $\mathrm{HS}+\mathrm{CH}_{2} \mathrm{CH}_{2} \mathrm{SH}$, a value of $74 \pm 2 \mathrm{kcal} / \mathrm{mol}$ is derived for the bond dissociation energy of $\mathrm{HS}-\mathrm{CH}_{2} \mathrm{CH}_{2} \mathrm{SH}$ at $0 \mathrm{~K}\left[\mathrm{D}_{0}\left(\mathrm{HS}-\mathrm{CH}_{2} \mathrm{CH}_{2} \mathrm{SH}\right]\right.$. 
Angular distribution measurements for $\mathrm{SH}$ yield an anisotropic parameter $\beta=-0.4 \pm 0.1$ for the $\mathrm{HS}+\mathrm{CH}_{2} \mathrm{CH}_{2} \mathrm{SH}$ process, indicating that the $\mathrm{C}-\mathrm{S}$ bond fission is fast with respect to molecular rotation.

In the photodissociation of thiophene at $193.3 \mathrm{~nm}$, the thiophene biradical decay dynamics has been studied as the primary laser photofragmentation product. The derived $\mathrm{P}\left(\mathrm{E}_{\mathrm{c} . \mathrm{m}}\right)$ for these processes show characteristics of unimolecular decay.

In the scattering cross section measurements for $\mathrm{O}\left({ }^{3} \mathrm{P}\right)\left[\mathrm{SO}\left(\mathrm{X},{ }^{3} \Sigma^{*}\right)\right]+\mathrm{He}[\mathrm{Ne}, \mathrm{Ar}, \mathrm{Kr}]$, the scattering behavior for $\mathrm{O}\left({ }^{3} \mathrm{P}\right)+\mathrm{He}[\mathrm{Ne}, \mathrm{Ar}, \mathrm{Kr}]$ obeys the rigid sphere model at high velocities. The measurements for $\mathrm{SO}\left(\mathrm{X}^{3} \Sigma^{*}\right)+\mathrm{He}[\mathrm{Ne}, \mathrm{Ar}, \mathrm{Kr}]$ show that the interaction potential is of the form $V(r)= \pm C_{n} / r^{n}$. Values for $C_{n}$ and $n$ were also determined. 
Photodissociation dynamics of polyatomic molecules

by

Hequan Zhao

A dissertation submitted to the graduate faculty in partial fulfillment of the requirements for the degree of DOCTOR OF PHILOSOPHY

Major: Physical Chemistry

Major Professor: Cheuk-Yiu Ng

Iowa State University

Ames, Iowa

1997 
Graduate College

Iowa State University

This is to certify that the Doctoral dissertation of

Hequan Zhao

has met the dissertation requirements of Iowa State University
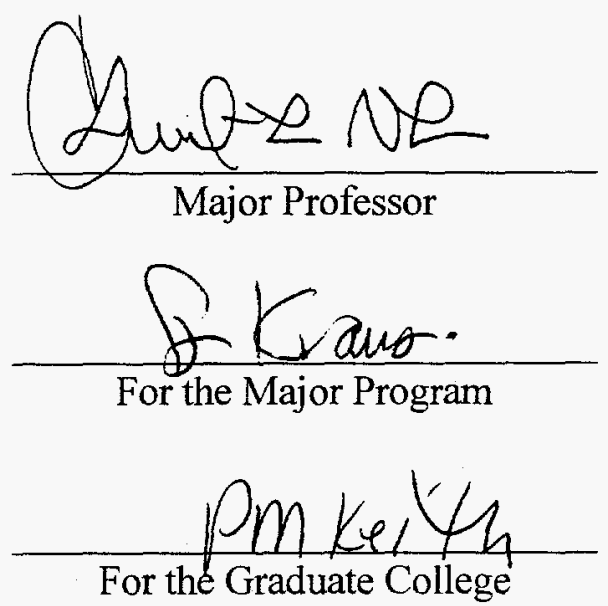


\section{TABLE OF CONTENTS}

GENERAL INTRODUCTION

Introduction

Dissertation Organization

References

A LASER PHOTOFRAGMENTATION TIME-OF-FLIGHT MASS

SPECTROMETRIC STUDY OF ACETOPHENONE AT 193 AND 248 NM Abstract

Introduction

Experimental and Theoretical Methods

Results and Discussion

Conclusion

References

A 193 NM LASER PHOTOFRAGMENTATION TIME-OF-FLIGHT MASS SPECTROMETRIC STUDY OF DIMETHYLSULFOXIDE

Abstract

Introduction

Experimental and Theoretical Methods

Results and Discussion

Conclusion

References

193 NM LASER PHOTOFRAGMENTATION TIME-OF-FLIGHT MASS SPECTROMETRIC STUDY OF $\mathrm{HSCH}_{2} \mathrm{CH}_{2} \mathrm{SH}$

Abstract

Introduction

Experimental and Theoretical Methods

Results and Discussion

Conclusion

References 
THIOPHENE BIRADICAL DECAY OF THE PRIMARY LASER

PHOTOFRAGMENTATION PRODUCT AT 193 NM

Abstract

Introduction

111

Experimental

Results and Discussion

Conclusion

References

SCATTERING CROSS SECTIONS FOR O $\left({ }^{3} \mathrm{P}\right)\left[\mathrm{SO}\left(\mathrm{X},{ }^{3} \Sigma^{*}\right)\right]+$ $\mathrm{HE}[\mathrm{NE}, \mathrm{AR}, \mathrm{KR}]$

Abstract

136

Introduction

136

Experimental

141

Results and Data Analysis

141

Discussion

Conclusion 153

References

134

GENERAL CONCLUSION 


\section{ACKNOWLEDGMENTS}

Many people have assisted me during my $\mathrm{Ph} . \mathrm{D}$. studies at Iowa State University. At this time, I would like to express my cordial appreciation.

First, I deeply thank Dr. Cheuk-Yiu Ng for his support, understanding and assistance in my research. I am strongly impressed by his insight in science and his enthusiastiasm for work. I have greatly benefited from his guidance.

I would like to thank Dr. Chung-Lin Liao and Mr. Chu-Xiong Liao for their assistance to my experiments. We worked together to repair the excimer laser to increase laser energy. I am grateful to Mr. Jerry Flesch for helping me to use the mass spectrometer and the leak detector. I also thank Mr. Eldon Ness, Terry Soseman, and Dick Egger in the chemistry machine shop for their invaluable service. I am grateful to Y.-S. Cheung for conducting the $a b$ initio calculations in order to explain my experimental data. I also thank Dave Baran, Dan Heck and Troy Tetzlaff for editing my writing. I have enjoyed my time with them.

Finally, I deeply thank my family for their support and understanding. My wife, Guijuan Wang, took a lot of time to take care of our son. Whenever I felt upset about my experiments, she always encouraged me. 


\section{GENERAL INTRODUCTION}

\section{Introduction}

The study of the photodissociation dynamics of polyatomic molecules has attracted great interest. The measurement of maximum translational energy release can be used to calculate the specific bond energy of molecules, which is essential in determining the chemical reaction enthalpy. ${ }^{1}$ The pathway identifications of photodissociation molecules provide information for the photochemical reaction mechanisms. Furthermore, photodissociation can produce radicals in a pure state to be used in studies of the interactions or reactions between radicals and molecules.

Photodissociation of polyatomic molecules generally involves more than one product process, resulting from the multi-dimensional nature of the excited potential energy surfaces and the efficient energy redistribution between the internal degrees of motion of the excited precursor molecules. Because of the accessibility of multi-channel dissociation pathways, the identification of nascent products, as well as data analysis for such dissociation processes, poses a great challenge to experimentalists. ${ }^{2}$

Photodissociation of acetophenone (a model of the polyatomic molecule ) at $193 \mathrm{~nm}$ and $248 \mathrm{~nm}$ has been conducted. Due to two unequivalent $\mathrm{C}-\mathrm{C}$ bonds, two primary processes have been observed.

For a symmetric molecule, such as acetone $\left[\left(\mathrm{CH}_{3}\right)_{2} \mathrm{CO}\right]$, two equivalent $\mathrm{C}-\mathrm{C}$ bonds can be broken. In this case the question of whether the products $\mathrm{CH}_{3}+\mathrm{CO}+\mathrm{CH}_{3}$ are formed sequentially or concertedly ${ }^{3}$ needs to be answered. ${ }^{4-6}$ Dimethylsulfoxide $\left[\left(\mathrm{CH}_{3}\right)_{2} \mathrm{SO}\right]$ is a sulfur analog of acetone $\left[\left(\mathrm{CH}_{3}\right)_{2} \mathrm{CO}\right]$. Being the simplest sulfoxide, the 
photochemistry of $\left(\mathrm{CH}_{3}\right)_{2} \mathrm{SO}$ represents a model system for understanding sulfoxide photochemistry. Therfore, we choose DMSO as another model for the study of the photodissociation dynamics of polyatomic molecules. ${ }^{7}$

\section{Dissertation Organization}

The thesis is composed of five papers prepared in a format ready for publication. The tables, figures, and references mentioned in each paper pertain only to that paper. The first paper is a typical example for studies of photodissociation of polyatomic molecules. In this paper, photodissociation studies of acetophene $\left(\mathrm{C}_{6} \mathrm{H}_{5} \mathrm{COCH}_{3}\right)$ at 193 $\mathrm{nm}$ and $248 \mathrm{~nm}$ are presented. Due to the multi-process property, experimental and data fitting techniques were applied to identify the processes. The second paper is the photodissociation study of dimethylsulfoxide [DMSO, $\left(\mathrm{CH}_{3}\right)_{2} \mathrm{SO}$ ] at $193 \mathrm{~nm}$. DMSO is a sulfur analog of acetone in which two chemical bonds may be broken with one photon. In this study, the $\mathrm{CH}_{3} \mathrm{SO}$ radical was directly detected. Evidently, this is a stepwise dissociation process. The third paper is the photodissociation study of $\mathrm{HSCH}_{2} \mathrm{CH}_{2} \mathrm{SH}$. The C-S bond energy of this compound is reported for the first time. The fourth paper is the photodissociation of thiophene $\left(\mathrm{C}_{4} \mathrm{H}_{4} \mathrm{~S}\right)$, which is a cyclic organic molecule containing a sulfur atom. Since the primary dissociation products cannot be observed due to the kinematic constraints, the biradical $(\bullet \mathrm{C} 4 \mathrm{H} 4 \mathrm{~S} \bullet)$ decay dynamics were studied. The fifth paper is a study of the radical and atomic interactions using the photodissociation products obtained from the photodissociation of $\mathrm{SO}_{2}$. 


\section{References}

(1) H.-Q Zhao, Y.-S. Cheung, C.-X. Liao, C. Y. Ng, Wai-Kee Li, and See-Wing, J. Chem. Phys. 104, 130(1996).

(2) C.-W. Hsu, C.-L. Liao, Z.-X. Ma, and C. Y. Ng, J. Phys. Chem. 99, 1760 (1995).

(3) C. E. M. Strauss and P. L. Houston, J. Phys. Chem. 94, 8751 (1990).

(4) K. A. Trentelman, S. H. Kable, D. B. Moss, and P. L. Houston, J. Chem. Phys. 91, 7498 (1989).

(5) S. W. North, D. A. Blank, J. D. Gezelter, C. A. Longfellow, and Y. T. Lee, J. Chem. Phys. 102, 4447 (1995).

(6) S. K. Kim, S. Pederson, and A. H. Zewail, J. Chem. Phys. 103, 477 (1995).

(7) H.-Q. Zhao, Y.-S.Cheung, D. P. Heck, C. Y. Ng, T. Tetzlaff, and W. Jenks, J. Chem. Phys. 106, 86 (1997). 


\author{
A LASER PHOTOFRAGMENTATION TIME-OF-FLIGHT \\ MASS SPECTOROMETRIC STUDY OF ACETOPHENONE AT 193 AND 248 NM \\ A paper accepted by the Journal of chemical Physics \\ Zhao, H.Q., Cheung, Y-S., Liao, C-L., Liao, C-X., Ng, C.Y.
}

\begin{abstract}
The photodissociation of acetophenone $\left(\mathrm{C}_{6} \mathrm{H}_{5} \mathrm{COCH}_{3}\right)$ at 193 and $248 \mathrm{~nm}$ has been studied using the time-of-flight (TOF) mass spectrometric technique. For hv=193 nm, two major primary processes, $\mathrm{C}_{6} \mathrm{H}_{5} \mathrm{COCl}_{3}-\mathrm{n} v \rightarrow \mathrm{C}_{6} \mathrm{H}_{5} \mathrm{CO}-\mathrm{CH}_{3}$ [process (1)] and $\mathrm{C}_{0} \mathrm{H}_{5}-\mathrm{CH}_{5} \mathrm{CO}$ [process (2)], are observed with comparable cross sections. Data analysis shows that $\approx 30-50 \%$ of primary $\mathrm{C}_{6} \mathrm{H}_{5} \mathrm{CO}$ and $\mathrm{CH}_{3} \mathrm{CO}$ radicals further decomposes, yielding secondary products $\mathrm{C}_{6} \mathrm{H}_{5}$ $+\mathrm{CO}$ and $\mathrm{CH}_{3}+\mathrm{CO}$, respectiveiy. The translational energy release measurements indicate that for both processes (1) and (2) at $193 \mathrm{~nm}, \approx 25-30 \%$ of the available energy is channeled into kinetic energies of the primary photofragments. Measurements at $h v=248 \mathrm{~nm}$ reveal that the branching ratio of process (2) to process ( 1 ) is $\approx 0.01$. For process ( 1 ) at $h v=248 \mathrm{~nm}, \approx 42 \%$ of the available energy is directed as the kinetic energy of the photofragments. The observed maximum kinetic energy reiease for process (1) at $248 \mathrm{~nm}$ yields a value of $85.0 \pm 2.2 \mathrm{kcal} / \mathrm{mol}$ for the $\mathrm{C}_{6} \mathrm{H}_{5} \mathrm{CO}-\mathrm{CH}_{3}$ bond dissociation energy at $0 \mathrm{~K}\left(\mathrm{D}_{0}\right)$. The photofragment angular distributions are found to be isotropic for both processes (1) and (2) at $\mathrm{hv}=193 \mathrm{~nm}$ and for process (1) at $\mathrm{hv}=$ $248 \mathrm{~nm}$. A minor photodissociation process $\mathrm{C}_{6} \mathrm{H}_{5} \mathrm{COCH}_{3}+\mathrm{hv} \rightarrow \mathrm{C}_{6} \mathrm{H}_{5} \mathrm{CH}_{3}+\mathrm{CO}$ is identified at both $h v=193$ and $248 \mathrm{~nm}$. The energetics for the dissociation reactions of acetophenone have also been investigated using $a b$ initio Gaussian-2-type procedures. The heats of formation at $0 \mathrm{~K}$
\end{abstract}


$\left(\Delta_{\mathrm{f}} \mathrm{H}_{0}^{\circ}\right)$ for $\mathrm{C}_{6} \mathrm{H}_{5} \mathrm{CO}$ and $\mathrm{C}_{6} \mathrm{H}_{5}$ calculated using the isodesmic reaction scheme are $33.9 \pm 1.3$ and $87.6 \pm 1.0 \mathrm{kcal} / \mathrm{mol}$, respectively. These results suggest that the literature $\Delta_{\mathrm{f}} \mathrm{H}^{\circ}{ }_{0}$ values for $\mathrm{C}_{6} \mathrm{H}_{5} \mathrm{CO}$ and $\mathrm{C}_{6} \mathrm{H}_{5}$ are likely to be high by $3-4 \mathrm{kcal} / \mathrm{mol}$. These theoretical $\Delta_{\mathrm{f}} \mathrm{H}^{\circ}$ values for $\mathrm{C}_{6} \mathrm{H}_{5} \mathrm{CO}$ and $\mathrm{C}_{6} \mathrm{H}_{5}$ yield a theoretical $\mathrm{D}_{0}\left(\mathrm{C}_{6} \mathrm{H}_{5} \mathrm{CO}-\mathrm{CH}_{3}\right)$ value of $85.1 \pm 1.4 \mathrm{kcal} / \mathrm{mol}$, which is in excellent accord with the experimental results obtained in the present study.

\section{Introduction}

The ultraviolet (UV) photochemistry of alkyl ketones ${ }^{1-5}$ and related molecules ${ }^{5-9}$ has been the subject of many recent laser excitation studies. Upon absorption of a UV photon, ketone is known to dissociate efficiently via C-CO bond cleavage, resulting in acyl and alkyl radicals. ${ }^{1-5,10}$ Since the $\mathrm{C}-\mathrm{CO}$ bond of an acyl radical is weak, excited acyl radicals formed at a sufficiently high internal energy have been found to undergo further decomposition, producing $\mathrm{CO}$ and alkyl radicals. ${ }^{1,5,7,11}$ Acyl and alkyl radicals are important intermediates in combustion and atmospheric process. ${ }^{12}$ The knowledge of the UV photochemistry of ketone is relevant for the preparation of these radicals for spectroscopic and reactivity studies. Recent excimer laser photofragmentation time-of-flight (TOF) mass spectrometric experiments have provided detailed information concerning the dissociation mechanism of acetone $\left(\mathrm{CH}_{3} \mathrm{COCH}_{3}\right) \cdot{ }^{1,2}$ Both acetyl $\left(\mathrm{CH}_{3} \mathrm{CO}\right)$ and methyl $\left(\mathrm{CH}_{3}\right)$ radicals are observed in the $248 \mathrm{~nm}$ photodissociation of $\mathrm{CH}_{3} \mathrm{COCH}_{3}$, whereas $\mathrm{CO}$ $+2 \mathrm{CH}_{3}$ are identified to be products at $193 \mathrm{~nm}^{1}$ A analysis of the TOF spectra for $\mathrm{CH}_{3}$ and $\mathrm{CO}$ has established that the formation of $\mathrm{CO}+2 \mathrm{CH}_{3}$ from $\mathrm{CH}_{3} \mathrm{COCH}_{3}$ at $193 \mathrm{~nm}$ is governed by a stepwise mechanism. ${ }^{1}$ 
The photochemistry of acetophenone $\left(\mathrm{C}_{6} \mathrm{H}_{5} \mathrm{COCH}_{3}\right)$, the simplest aromatic ketone, has received little attention compared to that of $\mathrm{CH}_{3} \mathrm{COCH}_{3}$. Early photochemical studies of acetophenone were motivated by the search for a convenient source of phenol radicals. ${ }^{13,14}$ The gas phase absorption spectrum for $\mathrm{C}_{6} \mathrm{H}_{5} \mathrm{COCH}_{3}$ in the region of $210-380 \mathrm{~nm}$ exhibits three broad peaks centered at 325,275 , and $230 \mathrm{~nm}$, which are assigned to the $S_{0} \rightarrow S_{1}, S_{0} \rightarrow S_{2}$, and $S_{0} \rightarrow$ $S_{3}$ transitions, respectively. ${ }^{10,15}$ The absorption cross section for the $S_{0} \rightarrow S_{3}$ peak is significantly stronger than that of the $S_{0} \rightarrow S_{2}$ peak, which is in turn stronger than that of the $S_{0} \rightarrow S_{1}$ peak. The first excited singlet $\mathrm{S}_{1}$ or ${ }^{1}\left(n, \pi^{*}\right)$ state of acetophenone is formed by an electron from the nonbonding orbital $(n)$ localized at the $O$ atom being excited to the antibonding $\pi^{*}$ orbital of the carbonyl group. The existence of an aromatic ring adjacent to the carbonyl group in simple aromatic ketones, such as acetophenone, is likely to facilitate intramolecular energy transfer, and hence inhibits the dissociative channels. Due to a small energy gap between the $S_{1}$ and $T_{1}$ [or ${ }^{3}(n$, $\left.\pi^{*}\right)$ ] states, the $S_{1}$ states of simple aromatic ketones are known to undergo rapid intersystem crossing to the $T_{1}$ state, resulting in high phosphorescence quantum yields. ${ }^{10,15}$ Similar intersystem crossing processes are expected to follow the $S_{2}$ and $S_{3}$ states. Thus, the photochemistry of $S_{1}$ as well as $S_{2}$ and $S_{3}$ states may actually take place from triplet potential energy surfaces.

The present work deals with the measurement and analysis of photofragment translational energy distributions and recoil anisotropies for the photodissociation of acetophenone at $193 \mathrm{~nm}$ and $248 \mathrm{~nm}$. The photon wavelength of $248 \mathrm{~nm}$ falls between the $S_{0} \rightarrow S_{2}$ and $S_{0} \rightarrow S_{3}$ absorption peaks. ${ }^{15}$ The previous kinetic study concluded that following $S_{0} \rightarrow S_{2}$ excitation, 
triplet acetophenone dissociates exclusively into $\mathrm{C}_{6} \mathrm{H}_{5} \mathrm{CO}$ (benzoyl radical) $+\mathrm{CH}_{3}{ }^{15}$ The absorption cross section for acetophenone at $193 \mathrm{~nm}$ is not available. However, judging from the trend of the absorption cross sections measured near $210 \mathrm{~nm}$, the absorption cross section at 193 $n m$ is likely to be much higher than that for the $S_{0} \rightarrow S_{3}$ peak. Excited states higher than $S_{3}$ are likely responsible for the photohemistry of acetophenone at $193 \mathrm{~nm}$. In accordance with the known UV photochemistry of ketone,,$^{1-5,10,15}$ we find that the dissociation of $\mathrm{C}_{6} \mathrm{H}_{5} \mathrm{COCH}_{3}$ at 193 and $248 \mathrm{~nm}$ is dominated by processes (1) and (2).

$$
\begin{aligned}
\mathrm{C}_{6} \mathrm{H}_{5} \mathrm{COCH}_{3}+\mathrm{hv} & \rightarrow \mathrm{C}_{6} \mathrm{H}_{5} \mathrm{CO}+\mathrm{CH}_{3} \\
& \rightarrow \mathrm{C}_{6} \mathrm{H}_{5}+\mathrm{CH}_{3} \mathrm{CO} \\
& \rightarrow \mathrm{C}_{6} \mathrm{H}_{5} \mathrm{CH}_{3}+\mathrm{CO}
\end{aligned}
$$

Evidence is found for the very minor occurrence of process (3).

Accurate energetic information about process (1) and (2) is essential for the analysis of the photofragment TOF spectra observed in this experiment. The heats of formation at $0 \mathrm{~K}$ (298K), $\mathrm{D}_{\mathrm{f}} \mathrm{H}^{\circ}\left(\mathrm{D}_{\mathrm{f}} \mathrm{H}^{\circ}{ }_{298}\right)$ for the radical fragments formed in processes (1) and (2) are not wellestablished. Thus, we have conducted a theoretical study of the energetics of $\mathrm{C}_{6} \mathrm{H}_{5} \mathrm{CO}, \mathrm{C}_{6} \mathrm{H}_{5}$, and $\mathrm{CH}_{3} \mathrm{CO}$ using established $a b$ initio quantum chemical schemes, such as the Gaussian-2 (G2) theory and its variances. ${ }^{16-19}$ We note that the G2 and G2(MP2) calculations of the heat of formation for the acetyl radical has been reported previously. ${ }^{20}$ The errors associated with G2 predictions for $\mathrm{D}_{\mathrm{f}} \mathrm{H}_{0}^{\circ}\left(\mathrm{D}_{\mathrm{f}} \mathrm{H}^{\circ}{ }_{298}\right)$ values of larger polyatomic species, such as $\mathrm{C}_{6} \mathrm{H}_{5} \mathrm{CO}$ and 
$\mathrm{C}_{6} \mathrm{H}_{5}$, may be higher than that of $\mathrm{CH}_{3} \mathrm{CO}^{20}$ Recent $\mathrm{G} 2$-type schemes, which combine the G2-type calculations and appropriate isodesmic reactions, have shown to provide accurate $\mathrm{D}_{\mathrm{f}} \mathrm{H}^{\circ}{ }_{0}\left(\mathrm{D}_{\mathrm{f}} \mathrm{H}^{\circ}{ }_{298}\right)$ predictions even for large polyatomic species. ${ }^{21-24}$

\section{Experimental And Theoretical Methods}

\section{A. Experiment}

The rotatable beam source laser photofragmentation TOF apparatus used in this study has been described in detail. ${ }^{25-28}$ The apparatus consists of three main components: an ArF excimer laser, a photodissociation chamber in which a rotatable supersonic molecular beam intersects with the excimer laser beam, and a linearly movable ultrahigh vacuum electron ionization quadrupole mass spectrometer (QMS).

A continuous molecular beam of $\mathrm{C}_{6} \mathrm{H}_{5} \mathrm{COCH}_{3}$ (about $3 \%$ seeded in $\mathrm{He}$ ) was produced by supersonic expansion through a nozzle $($ diameter $=0.125 \mathrm{~mm})$ at a total stagnation pressure $\left(\mathrm{P}_{\mathrm{o}}\right)$ of 360 Torr for $193 \mathrm{~nm}$ excitation and 560 Torr for $248 \mathrm{~nm}$ excitation. For the TOF measurement of $\mathrm{C}_{6} \mathrm{H}_{5}$ formed at $248 \mathrm{~nm}$ and $\theta_{\mathrm{lab}}$ (the angle between the molecular beam and the detector axis) $=10^{\circ}, P_{o}$ was reduced to 260 Torr in order to minimize the influence of dimers and clusters. The nozzle stagnation temperature $\left(T_{0}\right)$ was maintained at $\approx 180^{\circ} \mathrm{C}$ for $193 \mathrm{~nm}$ measurements and at $\approx 130^{\circ} \mathrm{C}$ for $248 \mathrm{~nm}$ measurements. During the experiment, the beam source, differential pumping, and photodissociation chambers were maintained at pressures of $\approx 1 \times 10^{-4}, 2 \times 10^{-6}$, and $\leq 1 \times 10^{-7}$ Torr, respectively. 
The energy of the excimer laser (Questek model 2460) used was in the range of 60-80 $\mathrm{mJ} /$ pulse at $193 \mathrm{~nm}$ or $100-140 \mathrm{~mJ} / \mathrm{pulse}$ at $248 \mathrm{~nm}$. The laser beam entered the photodissociation chamber through a $\mathrm{MgF}_{2}$ focusing lens and intersected the seeded $\mathrm{C}_{6} \mathrm{H}_{5} \mathrm{COCH}_{3}$ beam and the central axis of the QMS at $90^{\circ}$. The spot size of the excimer laser beam was estimated to be $\approx 5 \mathrm{~mm}^{2}$ at the photodissociation region.

The electron energy and emission current of the ionizer used were $75 \mathrm{eV}$ and $1.2 \mathrm{~mA}$, respectively. During the experiment, the ionization chamber pressure was maintained at $\leq 5 \times 10^{-11}$ Torr. Unless specified, the TOF spectra were taken at a flight path (the distance between the photodissociation region and the ionizer) of $65.5 \mathrm{~cm}$. The TOF spectra were recorded on a multichannel scaler (Stanford Research model SRT430), which was usually set to a channel width of $1.28 \mu \mathrm{s}$.

The velocity distribution of the parent $\mathrm{C}_{6} \mathrm{H}_{5} \mathrm{COCH}_{3}$ molecular beam was measured by recording the laser hole burning spectra at the mass corresponding to $\mathrm{C}_{6} \mathrm{H}_{5} \mathrm{COCH}_{3}{ }^{+}\left(\right.$or $\left.\mathrm{C}_{6} \mathrm{H}_{5}{ }^{+}\right)$at $\theta_{\mathrm{lab}}=0^{\circ}$. The measured speed profile of a species was then fitted to an assumed functional form, $f(v) \sim v^{2} \exp \left[-\left(v-v_{0}\right)^{2} / \alpha^{2}\right]$, where $v_{o}$ is the most probable speed and $\alpha$ is a measure of the width of the speed profile. ${ }^{25,29}$ For $193 \mathrm{~nm}$ excitation, these constants were determined to be $\mathrm{v}_{\mathrm{o}}=$ $1.79 \times 10^{5} \mathrm{~cm} / \mathrm{s}$ and $\alpha=0.91 \times 10^{4} \mathrm{~cm} / \mathrm{s}$. In the case of $248 \mathrm{~nm}$ excitation, $v_{0}=1.73 \times 10^{5} \mathrm{~cm} / \mathrm{s}$ and $\alpha=0.79 \times 104 \mathrm{~cm} / \mathrm{s}$ for $P_{0}=560$ Torr, while $V_{0}=1.44 \times 10^{5} \mathrm{~cm} / \mathrm{s}$ and $\alpha=1.15 \times 10^{5} \mathrm{~cm} / \mathrm{s}$ for $P_{o}=$ 260 Torr.

The ion drift times through the quadrupole mass filter were determined in a hole burming experiment. By recording the hole burning spectra of different ions, $\mathrm{C}_{6} \mathrm{H}_{5} \mathrm{COCH}_{3}{ }^{+}, \mathrm{C}_{6} \mathrm{H}_{5} \mathrm{CO}^{+}$, 
$\mathrm{CH}_{3} \mathrm{CO}^{+}, \mathrm{C}_{6} \mathrm{H}_{5}^{+}$, and $\mathrm{CH}_{3}^{+}$formed in electron impact ionization of $\mathrm{C}_{6} \mathrm{H}_{5} \mathrm{COCH}_{3}$, the corresponding arrival times $(\mathrm{t})$ and masses $(\mathrm{m})$ of these ions were used to fit the equation: $t=\mathrm{Am}^{1 / 2}+t_{0}$, where $t_{0}$ is the flight time of $\mathrm{C}_{6} \mathrm{H}_{5} \mathrm{COCH}_{3}$ from the photodissociation region to the ionizer and $\mathrm{A}$ is a constant. The procedure yielded a value of 4.114 for $\mathrm{A}$. That is, the ion drift time through the QMS is determined as $4.114 \mathrm{~m}^{1 / 2} \mu \mathrm{s}$. The actual flight times of photofragments were corrected for the corresponding ion drift times.

The analysis of the TOF data was performed by a forward simulation method. ${ }^{30,31}$ Briefly, the procedure began with a trial kinetic energy distribution $\mathrm{P}\left(\mathrm{E}_{\mathrm{c} . \mathrm{m}}\right)$, which was transformed to a TOF spectrum for comparison with the experimental TOF spectrum. Here, $E_{c . m}$ represents the center-of-mass kinetic energy of the photofragment. The $P\left(E_{c, m}\right)$ distribution was adjusted until satisfactory agreement between the experimental and calculated TOF data was obtained. For the determination of the threshold (maximum) $\mathrm{E}_{\mathrm{c} . \mathrm{m}}$ threshold of a dissociation process, the $P\left(E_{c . m}\right)$ distribution near the $E_{c . m}$ onset was also obtained by direct transformation ${ }^{25}$ of the TOF data.

In the measurements of the angular distribution, the laser light was polarized by a stack of ten quartz plates set at the Brewster angle. The electric vector $\mathbf{E}$ of the polarized laser beam was set perpendicular to the detector and then rotated to the desired angle with a $193 \mathrm{~nm}$ (or $248 \mathrm{~nm}$ ) half-wave retarder. The laser energy was measured by a pyroelectric detector, and was kept at $10 \mathrm{~mJ} /$ pulse at $193 \mathrm{~nm}$ and $15 \mathrm{~mJ} /$ pulse at $248 \mathrm{~nm}$.

\section{B. Ab initio calculations}

The G2 $a b$ initio theoretical procedure has been described in detail by Curtiss et $a l^{16}$ 
It is effectively corresponds to the QCISD(T)/6-311+G(3df,2p)//MP2/6-31G(d) level of theory. Briefly, at the G2 level of theory, molecular structures are optimized with the Hartree-Fock (HF) approach and the second-order Møller-Plesset perturbation theory (MP2), with all electrons included using the 6-31G(d) basis set [i.e., at the HF/6-31G(d) and MP2(full)/6-31G(d) levels]. Harmonic vibrational frequencies are calculated at the HF/6$31 G(d)$ geometries for stationary point characterization. All subsequent single-point calculations at higher levels involved are based on the MP2/6-31G(d) optimized structures. Approximations of $\mathrm{QCISD}(\mathrm{T}) / 6-311+\mathrm{G}(3 \mathrm{df}, 2 \mathrm{p})$ energies are obtained with frozen-core single-point calculations at the QCISD(T)/6-311G(d,p), MP4/6-311G(d,p), MP4/6$311+G(d, p)$, MP4/6-311G(2df,p), and MP2/6-311+G(3df,2p) levels. A small semiempirical correction is applied to account for high level correlation effects to obtain the total electronic energy $\left(\mathrm{E}_{\mathrm{e}}\right)$. The $\mathrm{HF} / 6-31 \mathrm{G}(\mathrm{d})$ harmonic vibrational frequencies, scaled by 0.8929 , are used for zero-point vibrational energy (ZPVE) correction. The total energy at $0 \mathrm{~K}\left(\mathrm{E}_{0}\right)$ is equal to $E_{e}+$ ZPVE. $^{33}$ All calculations are performed on IBM RS6000-320h and RS6000/340 workstations using the Gaussian 94 package of program. ${ }^{32}$ Unless specified, the $\mathrm{D}_{\mathrm{f}} \mathrm{H}^{\circ}$ and $\mathrm{D}_{\mathrm{f}} \mathrm{H}^{\circ}{ }_{298}$ values for the molecules are derived by evaluating the atomization energies and using the known experimental $\mathrm{D}_{\mathrm{f}} \mathrm{H}^{\circ}$ values of $\mathrm{C}(170.0 \mathrm{kcal} / \mathrm{mol}), \mathrm{O}\left({ }^{3} \mathrm{P}\right)(59.0 \mathrm{kcal} / \mathrm{mol})$, and $\mathrm{H}(51.63$ $\mathrm{kcal} / \mathrm{mol}){ }^{21,33}$

The G2(MP2) theory ${ }^{17}$ is a variation of the G2 procedure in which the single-point energies are calculated only at the QCISD(T)/6-311G(d,p) and MP2/6-311+G(3df,2p) levels. In this study, we have obtained $\mathrm{E}_{0}[\mathrm{G} 2(\mathrm{MP} 2)]$ values for $\mathrm{C}_{6} \mathrm{H}_{5}, \mathrm{CH}_{3} \mathrm{CO}, \mathrm{CH}_{3}$ and $\mathrm{CO}$. 
In view of the large size of $\mathrm{C}_{6} \mathrm{H}_{5} \mathrm{COCH}_{3}$ and $\mathrm{C}_{6} \mathrm{H}_{5} \mathrm{CO}$, the $\mathrm{QCISD}(\mathrm{T}) / 6-311 \mathrm{G}(\mathrm{d}, \mathrm{p})$ singlepoint energy calculations are computationally very demanding. Here, we have calculated the $\mathrm{E}_{0}$ values for $\mathrm{C}_{6} \mathrm{H}_{5} \mathrm{COCH}_{3}, \mathrm{C}_{6} \mathrm{H}_{5} \mathrm{CO}, \mathrm{CH}_{3} \mathrm{CO}, \mathrm{CH}_{3}$ and $\mathrm{CO}$ using the approximated G2(MP2,SVP) scheme introduced by Radom and co-workers. ${ }^{34}$ In the G2(MP2,SVP) scheme, the $\mathrm{QCISD}(\mathrm{T}) / 6-311 \mathrm{G}+(3 \mathrm{~d}, 2 \mathrm{p})$ energies are calculated using an additivity approximation, $\mathrm{E}[\mathrm{QCISD}(\mathrm{T}) / 6-311 \mathrm{G}+(3 \mathrm{df}, 2 \mathrm{p})]$ $\approx \mathrm{E}[\mathrm{QCISD}(\mathrm{T}) / 6-31 \mathrm{G}(\mathrm{d})]+\mathrm{E}[\mathrm{MP} 2 / 6-311+\mathrm{G}(3 \mathrm{df}, 2 \mathrm{p})]-\mathrm{E}[\mathrm{MP} 2 / 6-31 \mathrm{G}(\mathrm{d})]$

The G2(MP2,SVP) calculations have been shown to reproduce proton affinities for a set of reference molecules to within the $\mathrm{G} 2$ target accuracy of $2 \mathrm{kcal} / \mathrm{mol}$ but at significantly lower computational cost. Surprisingly, it is found that G2(MP2,SVP) performs better than G2

for hydrocarbons and radicals. ${ }^{34,35}$ Thus, we have applied the G2(MP2,SVP) procedure to calculate the $\mathrm{D}_{\mathrm{f}} \mathrm{H}_{0}^{\circ}\left(\mathrm{D}_{\mathrm{f}} \mathrm{H}_{298}^{\circ}\right)$ values of $\mathrm{C}_{6} \mathrm{H}_{5} \mathrm{COCH}_{3}, \mathrm{C}_{6} \mathrm{H}_{5} \mathrm{CO}, \mathrm{C}_{6} \mathrm{H}_{5}, \mathrm{CH}_{3} \mathrm{CO}, \mathrm{CH}_{3}$, and $\mathrm{CO}$.

\section{Results and Discussion}

\section{A. Thermochemistry}

The theoretical $\mathrm{E}_{0}, \mathrm{D}_{\mathrm{f}} \mathrm{H}^{\circ}$, and $\mathrm{D}_{\mathrm{f}} \mathrm{H}^{\circ}{ }_{298}$ values for $\mathrm{C}_{6} \mathrm{H}_{5} \mathrm{COCH}_{3}, \mathrm{C}_{6} \mathrm{H}_{5} \mathrm{CO}, \mathrm{C}_{6} \mathrm{H}_{5}$, $\mathrm{CH}_{3} \mathrm{CO}, \mathrm{CH}_{3}$, and $\mathrm{CO}$ obtained here and in previous calculations ${ }^{20,33}$ at the G2, G2(MP2), and G2(MP2,SVP) levels of theory are compared with the experimental ${ }^{21,22,36}$ values in Table I. In the case when only the $\mathrm{D}_{\mathrm{f}} \mathrm{H}^{\circ}{ }_{0}\left(\mathrm{D}_{\mathrm{f}} \mathrm{H}^{\circ}{ }_{298}\right)$ value for a species is known, the corresponding $\mathrm{D}_{\mathrm{f}} \mathrm{H}^{\circ}{ }_{298}\left(\mathrm{D}_{\mathrm{f}} \mathrm{H}^{\circ}\right)$ value are obtained using the calculated $\mathrm{HF} / 6-31 \mathrm{G}(\mathrm{d})$ vibrational frequencies. 
The $\mathrm{D}_{\mathrm{f}} \mathrm{H}^{\circ}(-0.55 \pm 0.6 \mathrm{kcal} / \mathrm{mol})$ and $\mathrm{D}_{\mathrm{f}} \mathrm{H}^{\circ} 298(-2.2 \pm 0.6 \mathrm{kcal} / \mathrm{mol})$ values for $\mathrm{CH}_{3} \mathrm{CO}$ have been determined at high levels of theory using an isodesmic reaction. ${ }^{20}$ This calculation supports the recent experimental $\mathrm{D}_{\mathrm{f}} \mathrm{H}^{\circ}{ }_{298}$ value of $-2.39 \pm 0.29 \mathrm{kcal} / \mathrm{mol}$ for $\mathrm{CH}_{3} \mathrm{CO}^{22}$ The $\mathrm{D}_{\mathrm{f}} \mathrm{H}^{\circ}{ }_{0}\left(\mathrm{D}_{\mathrm{f}} \mathrm{H}^{\circ}{ }_{298}\right)$ values calculated for $\mathrm{CH}_{3} \mathrm{CO}$ following the normal G2, G2(MP2), and G2(MP2,SVP) procedures are in satisfactory agreement with those of Ref. 20, with the G2(MP2,SVP) $\mathrm{D}_{\mathrm{f}} \mathrm{H}^{\circ}{ }_{0}\left(\mathrm{D}_{\mathrm{f}} \mathrm{H}^{\circ}{ }_{298}\right)$ value closest to the experimental finding. The G2(MP2,SVP) $\mathrm{D}_{\mathrm{f}} \mathrm{H}^{\circ}{ }_{298}$ value of $-20.8 \mathrm{kcal} / \mathrm{mol}$ for $\mathrm{C}_{6} \mathrm{H}_{5} \mathrm{COCH}_{3}$ is essentially identical to the literature value. ${ }^{21}$ However, the G2(MP2,SVP) $\mathrm{D}_{\mathrm{f}} \mathrm{H}^{\circ}{ }_{0}\left(\mathrm{D}_{\mathrm{f}} \mathrm{H}^{\circ}{ }_{298}\right)$ value of $32.5(29.9) \mathrm{kcal} / \mathrm{mol}$ for $\mathrm{C}_{6} \mathrm{H}_{5} \mathrm{CO}$ is higher than the experimental value of $30 \pm 2(26 \pm 2) \mathrm{kcal} / \mathrm{mol}$ by $\approx 3 \mathrm{kcal} / \mathrm{mol}$. In a recent study of the C-H bond energy of benzene, values of $84.3 \pm 0.6$ and $81.2 \pm 0.6 \mathrm{kcal} / \mathrm{mol}$ are recommended for $\mathrm{D}_{\mathbf{f}} \mathrm{H}_{0}^{\circ}\left(\mathrm{C}_{6} \mathrm{H}_{5}\right)$ and $\mathrm{D}_{\mathrm{f}} \mathrm{H}^{\circ}{ }_{298}\left(\mathrm{C}_{6} \mathrm{H}_{5}\right)$, respectively. ${ }^{36}$ These latter values are significantly lower than the corresponding G2(MP2) $\mathrm{D}_{\mathrm{f}} \mathrm{H}^{\circ}(93.0 \mathrm{kcal} / \mathrm{mol})$ and $\mathrm{D}_{\mathrm{f}} \mathrm{H}^{\circ}{ }_{298}$ $(90.3 \mathrm{kcal} / \mathrm{mol})$ values for $\mathrm{C}_{6} \mathrm{H}_{5}$. It is known that there is an accumulation of errors in the application of G2-type approaches to larger molecules. ${ }^{34,35,37,38}$ For example, the $\mathrm{D}_{\mathrm{f}} \mathrm{H}^{\circ}{ }_{0}$ and $\mathrm{D}_{\mathrm{f}} \mathrm{H}^{\circ}{ }_{298}$ values for benzene $\left(\mathrm{C}_{6} \mathrm{H}_{6}\right)$ are too low compared to known experimental values by 3.9 and $5.1 \mathrm{kcal} / \mathrm{mol}$, respectively. ${ }^{34,38} \mathrm{It}$ is interesting that the $\mathrm{D}_{\mathrm{f}} \mathrm{H}^{\circ}{ }_{0}[\mathrm{G} 2(\mathrm{MP} 2, \mathrm{SVP})](87.7$ $\mathrm{kcal} / \mathrm{mol})$ and $\mathrm{D}_{\mathrm{f}} \mathrm{H}^{\circ}{ }_{298}[\mathrm{G} 2(\mathrm{MP} 2, \mathrm{SVP})](85.0 \mathrm{kcal} / \mathrm{mol})$ values for $\mathrm{C}_{6} \mathrm{H}_{5}$, though still higher, are in better agreement with the experimental values. This observation is consistent with the previous finding that G2(MP2,SVP) performs better than G2 for hydrocarbons and radicals. ${ }^{35}$ 
Table I. $E_{0}[G 2(M P 2)], \Delta_{\mathrm{f}} \mathrm{H}^{\circ}{ }_{0}$ [G2(MP2)], $\Delta_{\mathrm{f}} \mathrm{H}^{\circ}{ }_{298}$ [G2(MP2)], $\Delta_{\mathrm{f}} \mathrm{H}^{\circ}{ }_{0}$ [G2(MP2,SVP)], $\Delta_{\mathrm{f}} \mathrm{H}^{\circ}{ }_{298}[\mathrm{G} 2(\mathrm{MP} 2, \mathrm{SVP})]$, and $\Delta_{\mathrm{f}} \mathrm{H}^{\circ}{ }_{0}$ (expt) values for $\mathrm{C}_{6} \mathrm{H}_{5} \mathrm{COCH}_{3}, \mathrm{C}_{6} \mathrm{H}_{5} \mathrm{CO}, \mathrm{C}_{6} \mathrm{H}_{5}$, $\mathrm{CH}_{3} \mathrm{CO}$, and $\mathrm{CH}_{3}$.

\begin{tabular}{|c|c|c|c|c|c|}
\hline \multirow[b]{2}{*}{ Species } & \multicolumn{2}{|l|}{ Theory ${ }^{a}$} & \multicolumn{3}{|c|}{ Experiment $^{b}$} \\
\hline & $\begin{array}{l}\mathrm{E}_{0} \\
\text { (hartree) }\end{array}$ & $\begin{array}{c}\Delta_{\mathrm{f}} \mathrm{H}^{\circ} \\
(\mathrm{kcal} / \mathrm{mol})\end{array}$ & $\begin{array}{l}\Delta_{\mathrm{H}} \mathrm{H}_{298} \\
(\mathrm{kcal} / \mathrm{mol})\end{array}$ & $\begin{array}{c}\Delta_{\mathrm{f}} \mathrm{H}^{\circ} \\
(\mathrm{kcal} / \mathrm{mol})\end{array}$ & $\begin{array}{l}\Delta_{\mathrm{f}}{ }^{\circ} 298 \\
(\mathrm{kcal} / \mathrm{mol})\end{array}$ \\
\hline $\mathrm{C}_{6} \mathrm{H}_{5} \mathrm{COCH}_{3}$ & -384.18059 & $-16.0^{c}$ & $-20.8^{c}$ & -15.9 & $-20.7 \pm 0.4$ \\
\hline $\mathrm{C}_{6} \mathrm{H}_{5} \mathrm{CH}_{3}$ & - & - & - & $17.5 \pm 0.1$ & $12.0 \pm 0.1$ \\
\hline $\mathrm{C}_{6} \mathrm{H}_{5} \mathrm{CO}$ & -344.30374 & $\begin{array}{l}32.5^{\mathrm{c}} \\
33.9 \pm 1.3^{\mathrm{g}}\end{array}$ & $\begin{array}{l}29.9^{\mathrm{c}} \\
30.6 \pm 0.7^{\mathrm{g}}\end{array}$ & $\begin{array}{l}29 \pm 2^{\mathrm{d}} \\
33.3 \pm 2.2^{\mathrm{h}}\end{array}$ & $\begin{array}{l}26.1 \pm 2^{d} \\
29.4 \pm 2.3^{h}\end{array}$ \\
\hline $\mathrm{C}_{6} \mathrm{H}_{5}$ & $\begin{array}{l}-231.09198 \\
-231.08923\end{array}$ & $\begin{array}{l}93.0^{\mathrm{e}} \\
87.7^{\mathrm{c}} \\
87.6 \pm 1.0^{\mathrm{g}}\end{array}$ & $\begin{array}{l}90.3^{\mathrm{e}} \\
85.0^{\mathrm{c}} \\
84.5 \pm 0.6^{\mathrm{g}}\end{array}$ & $84.3 \pm 0.6$ & $81.2 \pm 0.6$ \\
\hline $\mathrm{CH}_{3} \mathrm{CO}$ & $\begin{array}{l}-152.93546^{d} \\
-152.93156 \\
-152.92757\end{array}$ & $\begin{array}{l}-1.3^{f} \\
-0.55 \pm 0.6^{i} \\
-1.5^{\mathrm{e}} \\
-0.9^{\mathrm{c}}\end{array}$ & $\begin{array}{l}-2.2 \pm 0.6^{\mathrm{i}} \\
-2.05^{\mathrm{c}}\end{array}$ & $-0.74 \pm 0.29$ & $-2.39 \pm 0.29$ \\
\hline $\mathrm{CH}_{3}$ & $\begin{array}{l}-39.74390 \\
-39.73695 \\
-39.74119\end{array}$ & $\begin{array}{l}35.7^{\mathrm{f}} \\
36.2^{\mathrm{e}} \\
36.3^{\mathrm{c}}\end{array}$ & $\begin{array}{l}35.1^{\mathrm{f}} \\
35.6^{\mathrm{e}} \\
35.7^{\mathrm{e}}\end{array}$ & $35.8 \pm 0.1$ & $35.0 \pm 0.1$ \\
\hline $\mathrm{CO}$ & $\begin{array}{l}-113.17749 \\
-113.17540 \\
-113.17908\end{array}$ & $\begin{array}{l}-29.0^{\mathrm{f}} \\
-30.1^{\mathrm{e}} \\
-30.4^{\mathrm{c}}\end{array}$ & $\begin{array}{l}-28.2^{\mathrm{f}} \\
-29.3^{\mathrm{e}} \\
-29.6^{\mathrm{c}}\end{array}$ & $-27.20 \pm 0.04$ & $-26.4 \pm 0.0$ \\
\hline
\end{tabular}

a). The theoretical $\Delta_{\mathrm{f}} \mathrm{H}^{\circ}{ }_{0}$ and $\Delta_{\mathrm{f}} \mathrm{H}^{\circ}{ }_{298}$ values are calculated using the $\Delta_{\mathrm{f}} \mathrm{H}^{\circ}$ (expt) values of $\mathrm{C}$ $(170.0 \mathrm{kcal} / \mathrm{mol}), \mathrm{O}\left({ }^{3} \mathrm{P}\right)(59.0 \mathrm{kcal} / \mathrm{mol})$, and $\mathrm{H}(51.63 \mathrm{kcal} / \mathrm{mol})$ from Ref. 21 , and theoretical $E_{0}$ values calculated at the G2, G2(MP2), or G2(MP2,SVP) level.

b). Unless specified, experimental values are from Ref. 21.

c). G2(MP2,SVP) values.

d). Reference 23;

e). G2(MP2) values;

f). G2 values.

g). Calculated using isodesmic reactions of Table II.

h). This work; i) Reference 20. Calculated using an isodesmic reaction. 
It has been demonstrated that more accurate heats of formation can be calculated by the use of isodesmic reactions rather than atomization energies as in standard G2-type procedures. ${ }^{34,37,38}$ The cancellation of errors in cases involving similar chemical bonds improves the agreement with experiment. In G2-type approaches, a semiempirical high level correction is involved. It was pointed out that the high level corrections can be canceled exactly for isodesmic schemes. ${ }^{38}$ In order to obtain reliable theoretical $\mathrm{D}_{\mathrm{f}} \mathrm{H}^{\circ}\left(\mathrm{D}_{\mathrm{f}} \mathrm{H}^{\circ}{ }_{298}\right)$ values for $\mathrm{C}_{6} \mathrm{H}_{5} \mathrm{CO}$ and $\mathrm{C}_{6} \mathrm{H}_{5}$, we have examined the variation of their calculated $\mathrm{D}_{\mathrm{f}} \mathrm{H}^{\circ}$ $\left(\mathrm{D}_{\mathrm{f}}{ }^{\circ}{ }_{298}\right)$ values at the G2(MP2) and G2(MP2,SVP) level by the use of selected isodesmic reactions shown in Table II. We find that for reactions involving radicals, such as $\mathrm{C}_{6} \mathrm{H}_{5} \mathrm{CO}$ and $\mathrm{C}_{6} \mathrm{H}_{5}$, the "bond separation" isodesmic reactions are not unique (see Table II, reactions i-iii for $\mathrm{C}_{6} \mathrm{H}_{5}$ and reactions v-viii for $\mathrm{C}_{6} \mathrm{H}_{5} \mathrm{CO}$ ). ${ }^{38}$ These reactions are selected because the energetics of all species involved are well known, except those for $\mathrm{C}_{6} \mathrm{H}_{5} \mathrm{CO}$ and $\mathrm{C}_{6} \mathrm{H}_{5}$. The uncertainties for $\mathrm{D}_{\mathrm{f}} \mathrm{H}^{\circ}{ }_{0}\left(\mathrm{D}_{\mathrm{f}} \mathrm{H}^{\circ}{ }_{298}\right)$ thus determined using individual isodesmic reactions are lower limits determined only by the uncertainties of the experimental $\mathrm{D}_{\mathrm{f}} \mathrm{H}^{\circ}{ }_{0}\left(\mathrm{D}_{\mathrm{f}} \mathrm{H}^{\circ}{ }_{298}\right)$ values used in the calculations. We have also calculated the G2(MP2,SVP) $\mathrm{D}_{\mathrm{f}} \mathrm{H}_{0}^{\circ}\left(\mathrm{D}_{\mathrm{f}} \mathrm{H}^{\circ}{ }_{298}\right)$ values of $\mathrm{C}_{6} \mathrm{H}_{5}$ and $\mathrm{C}_{6} \mathrm{H}_{5} \mathrm{CO}$ and using isodesmic reactions iv and $\mathrm{ix}$, respectively, (see Table II). As shown in the table, the $\mathrm{D}_{\mathrm{f}} \mathrm{H}^{\circ}\left(\mathrm{D}_{\mathrm{f}} \mathrm{H}^{\circ}{ }_{298}\right)$ values of $\mathrm{C}_{6} \mathrm{H}_{5}$ and $\mathrm{C}_{6} \mathrm{H}_{5} \mathrm{CO}$, thus derived are highly consistent, with the maximum deviations of $1.3 \mathrm{and} 2.2 \mathrm{kcal} / \mathrm{mol}$ for $\mathrm{D}_{\mathrm{f}} \mathrm{H}^{\circ}\left(\mathrm{D}_{\mathrm{f}} \mathrm{H}^{\circ}{ }_{298}\right)$ of $\mathrm{C}_{6} \mathrm{H}_{5}$ and $\mathrm{C}_{6} \mathrm{H}_{5} \mathrm{CO}$, respectively. We recommend the average values $87.6 \pm 1.0(84.5 \pm 0.6) \mathrm{kcal} / \mathrm{mol}$ for $\mathrm{D}_{\mathrm{f}} \mathrm{H}_{0}^{\circ}\left(\mathrm{D}_{\mathrm{f}} \mathrm{H}^{\circ}{ }_{298}\right)$ of $\mathrm{C}_{6} \mathrm{H}_{5}$ and $33.9 \pm 1.3(30.6 \pm 0.7) \mathrm{kcal} / \mathrm{mol}$ for $\mathrm{D}_{\mathrm{f}} \mathrm{H}^{\circ}{ }_{0}\left(\mathrm{D}_{\mathrm{f}} \mathrm{H}^{\circ}{ }_{298}\right)$ of $\mathrm{C}_{6} \mathrm{H}_{5} \mathrm{CO}$. We have conservatively assigned the uncertainties to be the maximum of the 
Table II. Values for $\Delta_{\mathrm{f}} \mathrm{H}^{\circ}$ and $\Delta_{\mathrm{f}} \mathrm{H}^{\circ}{ }_{298}$ of $\mathrm{C}_{6} \mathrm{H}_{5}$ and $\mathrm{C}_{6} \mathrm{H}_{5} \mathrm{CO}$ calculated using selected isodesmic reactions. ${ }^{a}$

\begin{tabular}{|c|c|c|c|c|}
\hline \multirow[b]{2}{*}{ Isodesmic reactions } & \multicolumn{2}{|c|}{ G2(MP2) } & \multicolumn{2}{|c|}{ G2(MP2,SVP) } \\
\hline & $\Delta_{\mathrm{f}} \mathrm{H}_{0}^{\circ}$ & $\Delta_{\mathrm{f}} \mathrm{H}^{\circ}{ }_{298}$ & $\Delta_{\mathrm{f}} \mathrm{H}^{\circ}{ }_{0}$ & $\Delta_{\mathrm{f}} \mathrm{H}^{\circ}{ }_{298}$ \\
\hline \multicolumn{5}{|l|}{$\mathrm{C}_{6} \mathrm{H}_{5}$} \\
\hline i. $\mathrm{C}_{6} \mathrm{H}_{5}+6 \mathrm{CH}_{4} \rightarrow 2 \mathrm{C}_{2} \mathrm{H}_{4}+\mathrm{C}_{2} \mathrm{H}_{3}+3 \mathrm{C}_{2} \mathrm{H}_{6}$ & 88.2 & 84.8 & 88.0 & 84.6 \\
\hline ii. $\mathrm{C}_{6} \mathrm{H}_{5}+6 \mathrm{CH}_{4} \rightarrow 3 \mathrm{C}_{2} \mathrm{H}_{4}+\mathrm{C}_{2} \mathrm{H}_{5}+2 \mathrm{C}_{2} \mathrm{H}_{6}$ & 87.3 & 84.3 & 86.4 & 83.9 \\
\hline iii. $\mathrm{C}_{6} \mathrm{H}_{5}+7 \mathrm{CH}_{4} \rightarrow 3 \mathrm{C}_{2} \mathrm{H}_{4}+3 \mathrm{C}_{2} \mathrm{H}_{6}+\mathrm{CH}_{3}$ & 88.6 & 85.1 & 87.4 & 84.6 \\
\hline iv. $\mathrm{C}_{6} \mathrm{H}_{5}-\mathrm{COCH}_{3}+\mathrm{CH}_{4} \rightarrow \mathrm{C}_{6} \mathrm{H}_{5}+\mathrm{CH}_{3}-\mathrm{COCH}$ & & & 87.0 & 84.2 \\
\hline \multicolumn{5}{|l|}{$\mathrm{C}_{6} \mathrm{H}_{5} \mathrm{CO}$} \\
\hline \multicolumn{3}{|c|}{ v. $\mathrm{C}_{6} \mathrm{H}_{5} \mathrm{CO}+8 \mathrm{CH}_{4} \rightarrow 2 \mathrm{C}_{2} \mathrm{H}_{4}+\mathrm{C}_{2} \mathrm{H}_{3}+4 \mathrm{C}_{2} \mathrm{H}_{6}+\mathrm{H}_{2} \mathrm{CO}$} & 34.6 & 31.0 \\
\hline \multicolumn{3}{|c|}{ vi. $\mathrm{C}_{6} \mathrm{H}_{5} \mathrm{CO}+8 \mathrm{CH}_{4} \rightarrow 3 \mathrm{C}_{2} \mathrm{H}_{4}+\mathrm{C}_{2} \mathrm{H}_{5}+3 \mathrm{C}_{2} \mathrm{H}_{6}+\mathrm{H}_{2} \mathrm{CO}$} & 33.5 & 30.3 \\
\hline \multicolumn{3}{|l|}{ vii. $\mathrm{C}_{6} \mathrm{H}_{5} \mathrm{CO}+8 \mathrm{CH}_{4} \rightarrow 3 \mathrm{C}_{2} \mathrm{H}_{4}+4 \mathrm{C}_{2} \mathrm{H}_{6}+\mathrm{HCO}$} & 34.2 & 30.6 \\
\hline \multicolumn{3}{|c|}{ viii. $\mathrm{C}_{6} \mathrm{H}_{5} \mathrm{CO}+9 \mathrm{CH}_{4} \rightarrow 3 \mathrm{C}_{2} \mathrm{H}_{4}+4 \mathrm{C}_{2} \mathrm{H}_{6}+\mathrm{H}_{2} \mathrm{CO}+\mathrm{CH}_{3}$} & 34.8 & 31.0 \\
\hline \multicolumn{3}{|l|}{ xi. $\quad \mathrm{C}_{6} \mathrm{H}_{5} \mathrm{CO}-\mathrm{CH}_{3}+\mathrm{CH}_{3} \rightarrow \mathrm{C}_{6} \mathrm{H}_{5} \mathrm{CO}+\mathrm{H}_{3} \mathrm{C}-\mathrm{CH}_{3}$} & 32.6 & 29.9 \\
\hline
\end{tabular}

a) $\Delta_{\mathrm{f}} \mathrm{H}_{0}^{\circ}(\mathrm{kcal} / \mathrm{mol}$, expt $)$ and $\Delta_{\mathrm{f}} \mathrm{H}^{\circ}{ }_{298}(\mathrm{kcal} / \mathrm{mol}$, expt $)$ values used are from Refs. 21 and 35. 
differences between individually calculated $\mathrm{D}_{\mathrm{f}} \mathrm{H}^{\circ}\left(\mathrm{D}_{\mathrm{f}} \mathrm{H}^{\circ}{ }_{298}\right)$ values and the corresponding averages. Again, we note that these recommended $\mathrm{D}_{\mathrm{f}} \mathrm{H}^{\circ}{ }_{0}\left(\mathrm{D}_{\mathrm{f}} \mathrm{H}^{\circ}{ }_{298}\right)$ values for $\mathrm{C}_{6} \mathrm{H}_{5}$ and $\mathrm{C}_{6} \mathrm{H}_{5} \mathrm{CO}$ are in excellent agreement with the $\mathrm{D}_{\mathrm{f}} \mathrm{H}^{\circ}[\mathrm{G} 2(\mathrm{MP} 2, \mathrm{SVP})]$ and $\mathrm{D}_{\mathrm{f}} \mathrm{H}^{\circ}{ }_{298}[\mathrm{G} 2(\mathrm{MP} 2, \mathrm{SVP})]$ predictions. Comparing these values and the experimental results (Table I) indicates that the literature $\mathrm{D}_{\mathrm{f}} \mathrm{H}^{\circ}{ }_{0}\left(\mathrm{D}_{\mathrm{f}} \mathrm{H}^{\circ}{ }_{298}\right)$ values for $\mathrm{C}_{6} \mathrm{H}_{5}$ and $\mathrm{C}_{6} \mathrm{H}_{5} \mathrm{CO}$ are likely on the low side.

In Table III, we have compared the theoretical G2(MP2,SVP) and experimental $D_{0}$ ( $\mathrm{D}_{298}$ ) values for the $\mathrm{C}_{6} \mathrm{H}_{5} \mathrm{CO}-\mathrm{CH}_{3}, \mathrm{C}_{6} \mathrm{H}_{5}-\mathrm{COCH}_{3}, \mathrm{C}_{6} \mathrm{H}_{5}-\mathrm{CO}$, and $\mathrm{CH}_{3}-\mathrm{CO}$ bonds. The experimental $\mathrm{D}_{0}\left(\mathrm{D}_{298}\right)$ values for the $\mathrm{C}_{6} \mathrm{H}_{5} \mathrm{CO}-\mathrm{CH}_{3}$ and $\mathrm{C}_{6} \mathrm{H}_{5}-\mathrm{COCH}_{3}$ bonds are $4.4(5.0)$ and $2.3(4.4) \mathrm{kcal} / \mathrm{mol}$ lower than the corresponding theoretical predictions, while the experimental $\mathrm{D}_{0}\left(\mathrm{D}_{298}\right)$ values for the $\mathrm{C}_{6} \mathrm{H}_{5}-\mathrm{CO}$ and $\mathrm{CH}_{3}-\mathrm{CO}$ bonds are higher than the respective theoretical predictions by $4.8(3.2)$ and $1.5(1.7) \mathrm{kcal} / \mathrm{mol}$.

\section{B. Newton diagrams for photodissociation at 193 and $248 \mathrm{~nm}$}

Based on the conservation of energy,

$$
\begin{aligned}
\mathrm{E}(\mathrm{hv})+\mathrm{E}_{\mathrm{int}}\left(\mathrm{C}_{6} \mathrm{H}_{5} \mathrm{COCH}_{3}\right)=\mathrm{D}_{0}\left(\mathrm{C}_{6} \mathrm{H}_{5} \mathrm{CO}-\mathrm{CH}_{3} \text { or } \mathrm{C}_{6} \mathrm{H}_{5}-\mathrm{COCH}_{3}\right) \\
+\mathrm{E}_{\mathrm{int}}\left[\left(\mathrm{C}_{6} \mathrm{H}_{5} \mathrm{CO}+\mathrm{CH}_{3}\right) \text { or }\left(\mathrm{C}_{6} \mathrm{H}_{5}+\mathrm{CH}_{3} \mathrm{CO}\right)\right]+\mathrm{E}_{\mathrm{c} . \mathrm{m}},
\end{aligned}
$$

where $\mathrm{E}(\mathrm{h} v)$ is the dissociation photon energy $(147.9 \mathrm{kcal} / \mathrm{mol}$ for $\mathrm{h} v=193.3 \mathrm{~nm}$ and 115.3 $\mathrm{kcal} / \mathrm{mol}$ for $\mathrm{hv}=248 \mathrm{~nm}$ ); and $\mathrm{E}_{\text {int }}$ is the initial internal energy of $\mathrm{C}_{6} \mathrm{H}_{5} \mathrm{COCH}_{3}$ or its photofragments $\left(\mathrm{C}_{6} \mathrm{H}_{5} \mathrm{CO}+\mathrm{CH}_{3}\right.$ or $\left.\mathrm{C}_{6} \mathrm{H}_{5}+\mathrm{COCH}_{3}\right)$. Using the $\mathrm{HF} / 6-31 \mathrm{G}(\mathrm{d})$ vibrational 
Table III. Comparison of theoretical and experimental selected bond dissociation energies at 0 (298 K) for $\mathrm{C}_{6} \mathrm{H}_{5} \mathrm{COCH}_{3}, \mathrm{C}_{6} \mathrm{H}_{5} \mathrm{CO}$, and $\mathrm{CH}_{3} \mathrm{CO}^{2}$.

\begin{tabular}{lllllc}
\hline \hline & \multicolumn{2}{c}{ Theory [G2(MP2,SVP)] } & & \multicolumn{2}{c}{ Experiment } \\
\cline { 2 - 3 } Reactions & $\begin{array}{l}\mathrm{D}_{0} \\
(\mathrm{kcal} / \mathrm{mol})\end{array}$ & $\begin{array}{l}\mathrm{D}_{298} \\
(\mathrm{kcal} / \mathrm{mol})\end{array}$ & & $\begin{array}{c}\mathrm{D}_{0} \\
(\mathrm{kcal} / \mathrm{mol})\end{array}$ & $\begin{array}{c}\mathrm{D}_{298} \\
(\mathrm{kcal} / \mathrm{mol})\end{array}$ \\
\hline $\mathrm{C}_{6} \mathrm{H}_{5} \mathrm{COCH}_{3} \rightarrow \mathrm{C}_{6} \mathrm{H}_{5} \mathrm{CO}+\mathrm{CH}_{3}$ & 85.1 & 86.8 & & 80.7 & 81.8 \\
$\mathrm{C}_{6} \mathrm{H}_{5} \mathrm{COCH}_{3} \rightarrow \mathrm{C}_{6} \mathrm{H}_{5}+\mathrm{CH}_{3} \mathrm{CO}$ & 102.8 & 103.8 & & 99.5 & 99.5 \\
$\mathrm{C}_{6} \mathrm{H}_{5} \mathrm{CO} \rightarrow \mathrm{C}_{6} \mathrm{H}_{5}+\mathrm{CO}$ & 23.3 & 25.5 & & 28.1 & 28.7 \\
$\mathrm{CH}_{3} \mathrm{CO} \rightarrow \mathrm{CH}_{3}+\mathrm{CO}$ & 6.8 & 8.2 & & 9.3 & 11.0 \\
\hline \hline
\end{tabular}

a) Calculated using the experimental and theoretical G2(M2,SVP) $\Delta_{\mathrm{f}} \mathrm{H}^{\circ}\left(\Delta_{\mathrm{f}} \mathrm{H}^{\circ}{ }_{298}\right)$ values of Table I.

b) This work. 
frequencies for $\mathrm{C}_{6} \mathrm{H}_{5} \mathrm{COCH}_{3}$, the total thermal energy at $298 \mathrm{~K}$ for $\mathrm{C}_{6} \mathrm{H}_{5} \mathrm{COCH}_{3}$ is estmated to be $5.7 \mathrm{kcal} / \mathrm{mol}$. Considering the mild expansion conditions used in this experiment, we expect that the vibrational relaxation is inefficient and the rotational relaxation is incomplete. For an initial nozzle temperature of $130-180^{\circ} \mathrm{C}(403-453 \mathrm{~K})$, we estimate that the effective beam temperature for $\mathrm{C}_{6} \mathrm{H}_{5} \mathrm{COCH}_{3}$ is most likely in the range of $250-350 \mathrm{~K}$. Thus, after expansion, the parent $\mathrm{C}_{6} \mathrm{H}_{5} \mathrm{COCH}_{3}$ molecules may contain $\approx 5.7 \mathrm{kcal} / \mathrm{mol}$ of thermal energy.

Using Eq. (5) and the literature $\mathrm{D}_{0}$ values $\left[\mathrm{D}_{0}\left(\mathrm{C}_{6} \mathrm{H}_{5} \mathrm{CO}-\mathrm{CH}_{3}\right)=80.7 \mathrm{kcal} / \mathrm{mol}\right.$ and $\mathrm{D}_{0}\left(\mathrm{C}_{6} \mathrm{H}_{5}-\mathrm{COCH}_{3}\right)=99.5 \mathrm{kcal} / \mathrm{mol}$ ] (see Table III), we have constructed the Newton diagrams for the $\mathrm{C}_{6} \mathrm{H}_{5} \mathrm{CO}+\mathrm{CH}_{3}$ and $\mathrm{C}_{6} \mathrm{H}_{5}+\mathrm{COCH}_{3}$ processes. The Newton diagrams corresponding to $193 \mathrm{~nm}$ and $248 \mathrm{~nm}$ photodissociation are shown in Figs. 1(a) and 1(b), respectively, where $\mathrm{v}_{\mathrm{lab}}$ and $v_{c . m}$ are the laboratory and center-of-mass velocities for the photofragments, and $\theta_{\mathrm{lab}}$ and $\theta_{\mathrm{c} . \mathrm{m}}$ are the laboratory and center-of-mass angles, defined by the angles between the detector axis and molecular beam axis and between $v_{c . m}$ and the molecular beam axis, respectively. The $v_{0}$ values are $1.79 \times 10^{5} \mathrm{~cm} / \mathrm{s}$ for $193 \mathrm{~nm}$ excitation and $1.73 \times 10^{5} \mathrm{~cm} / \mathrm{s}$ for $248 \mathrm{~nm}$ excitation. The maximum $\mathrm{v}_{\mathrm{c} . \mathrm{m}}$ circles are calculated assuming $\mathrm{E}_{\mathrm{int}}\left[\left(\mathrm{C}_{6} \mathrm{H}_{5} \mathrm{CO}+\mathrm{CH}_{3}\right)\right.$ or $\left.\left(\mathrm{C}_{6} \mathrm{H}_{5}+\mathrm{CH}_{3} \mathrm{CO}\right)\right]=0$. Also shown in Figs. 1(a) and 1(b) are $\gamma$ and $\varepsilon$, which are defined as the angles between the laser electric field $\mathbf{E}$ and $v_{c \cdot m}$ and between $\mathbf{E}$ and the detector axis, respectively.

\section{Photodissociation at $193 \mathrm{~nm}$}

Figures (2a) and (2b) show the TOF spectra for $\mathrm{CH}_{3}$ observed at $\theta_{1 \mathrm{ab}}=15^{\circ}$ and $30^{\circ}$, respectively. The TOF spectrum for $\mathrm{C}_{6} \mathrm{H}_{5} \mathrm{CO}$ at $\theta_{\text {lab }}=15^{\circ}$ is depicted in Fig. 3. The direct detection of $\mathrm{C}_{6} \mathrm{H}_{5} \mathrm{CO}$ and $\mathrm{CH}_{3}$ signals confirms the occurrence of process (1). The $\mathrm{P}\left(\mathrm{E}_{\mathrm{c} . \mathrm{m}}\right)$ for process (1) (solid curve) shown in Fig. 4(a) is derived from the fast peaks in the $\mathrm{CH}_{3}$ TOF 


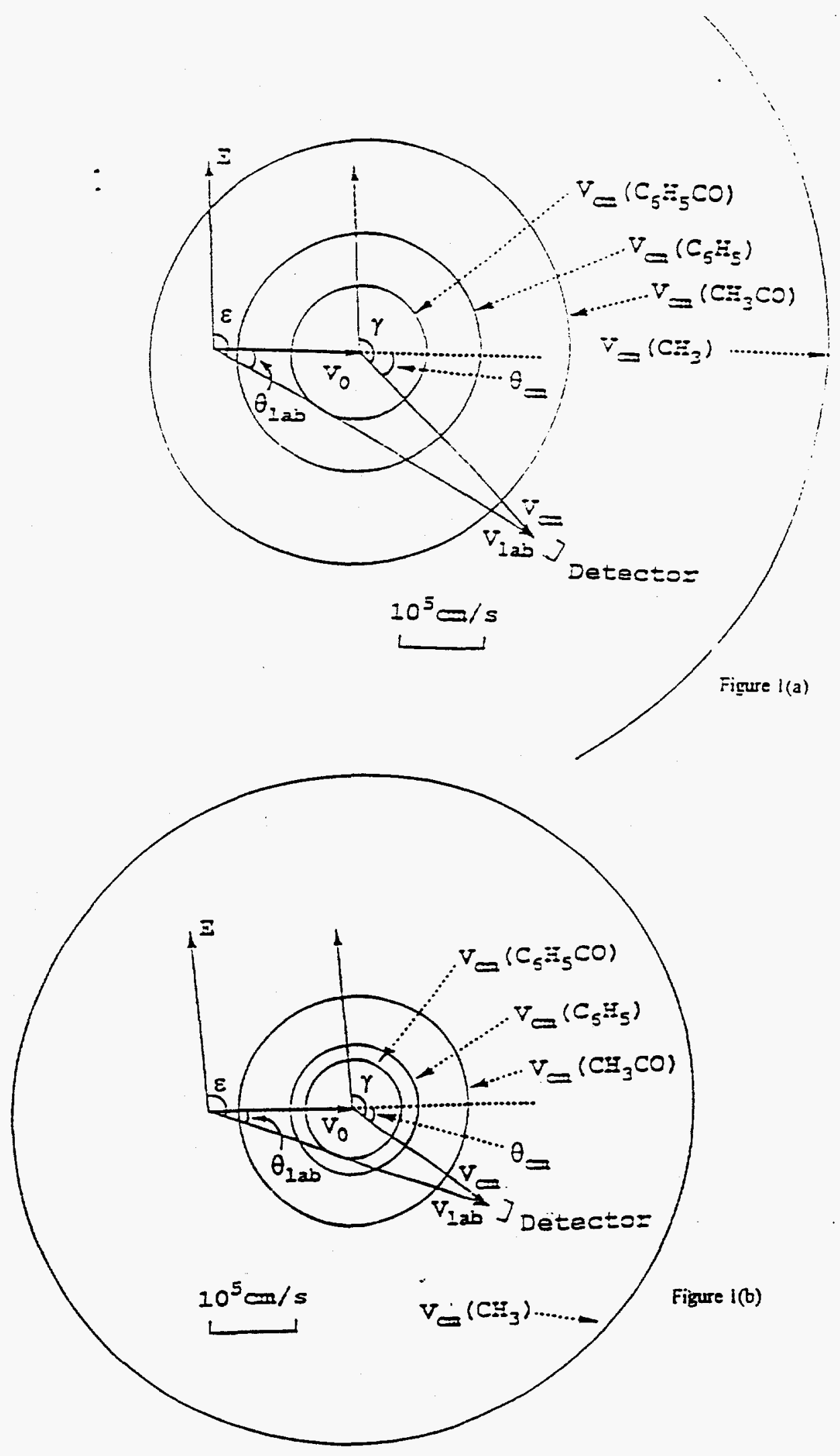




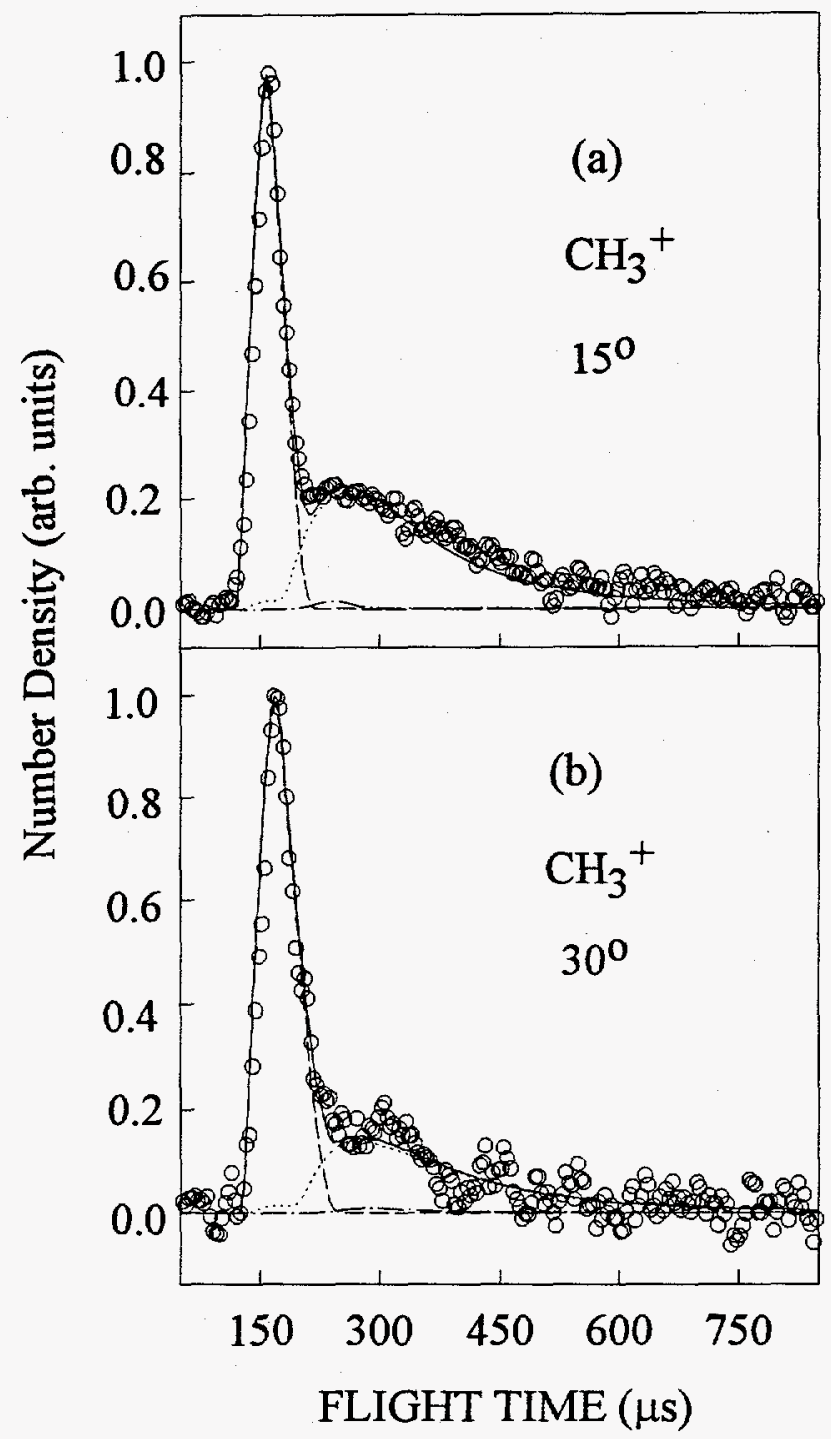

Figure 2 TOF spectra for $\mathrm{CH}_{3}$ at (a) $\theta_{\mathrm{lab}}=15^{\circ}$ and (b) $\theta_{\mathrm{lab}}=30^{\circ}$. Circles represent experimental data. Contributions are shown for $\mathrm{CH}_{3}$ (dashed line) from process (1), $\mathrm{CH}_{3} \mathrm{CO}$ (dot-dashed line) from process (2), and $\mathrm{CH}_{3}$ (dotted line) from process (8). 


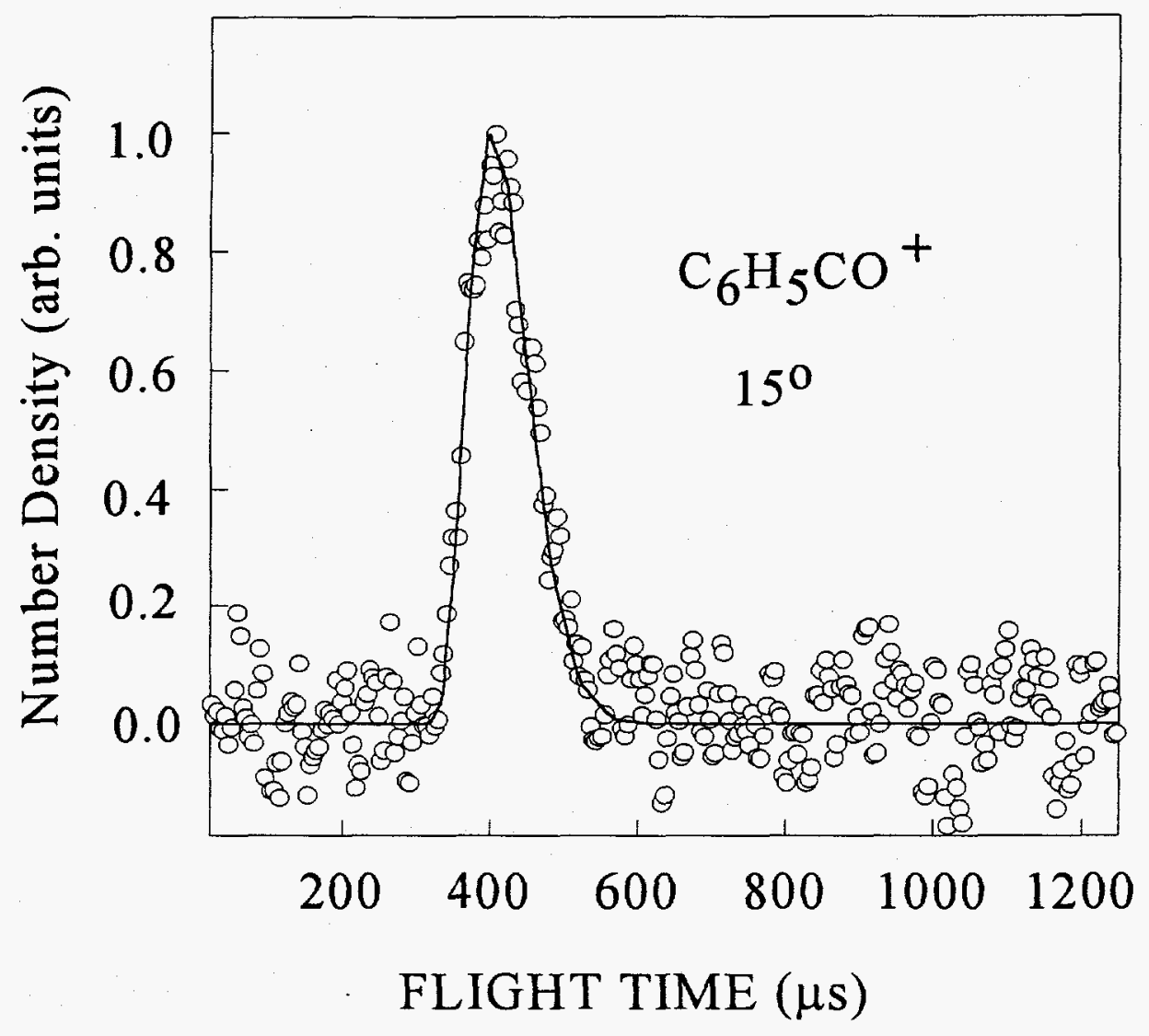

Figure 3 TOF spectrum for $\mathrm{C}_{6} \mathrm{H}_{5} \mathrm{CO}$ at $\theta_{\mathrm{lab}}=15^{\circ}$. Circles represent experimental data. 

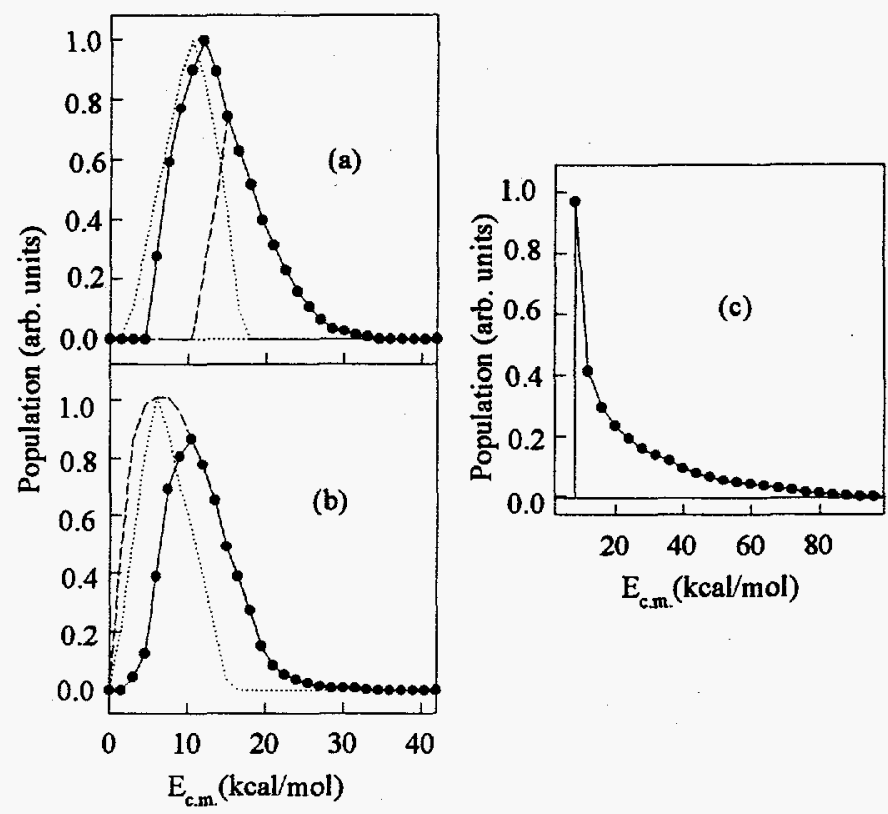

Figure 4 (a) The $\mathrm{P}\left(\mathrm{E}_{\text {c.m. }}\right)$ for process (1) derived by the TOF spectra for $\mathrm{CH}_{3}$ is shown as the solid curve. The part of the $P\left(E_{\text {c.m. }}\right)$ to the right of the dashed line fits the TOF spectrum for $\mathrm{C}_{6} \mathrm{H}_{5} \mathrm{CO}$ of Fig. 3. The $\mathrm{P}\left(\mathrm{E}_{\mathrm{c} . \mathrm{m}}\right)$ for the secondary dissociation process (6) derived by the TOF spectra for $\mathrm{C}_{6} \mathrm{H}_{5}$ and $\mathrm{CO}$ is shown by the dotted line. (b) The solid curve is the approximated $\mathrm{P}\left(\mathrm{E}_{\mathrm{c} . \mathrm{m}}\right)$ for process (2) derived by the TOF of $\mathrm{CH}_{3} \mathrm{CO}$ at $\theta_{\mathrm{lab}}=15^{\circ}$. The modified $\mathrm{P}\left(\mathrm{E}_{\mathrm{c.m}}\right.$. ) for process (2) (dashed curve) at $E_{\text {c.m. }}<11 \mathrm{kcal} / \mathrm{mol}$ is obtained by fitting the TOF spectrum for $\mathrm{C}_{6} \mathrm{H}_{5}$ at $\theta_{\mathrm{lab}}=15^{\circ}$. Thus, the complete $\mathrm{P}\left(\mathrm{E}_{\mathrm{c} . \mathrm{m} .}\right)$ for process $(2)$ is the combined dashed curve at $\mathrm{E}_{\mathrm{c.m} .}<11 \mathrm{kcal} / \mathrm{mol}$ and the solid curve at $\mathrm{E}_{\mathrm{c} . \mathrm{m} .} \geq 11 \mathrm{kcal} / \mathrm{mol}$. The $P\left(\mathrm{E}_{\mathrm{c.m} . \mathrm{m}}\right)$ for the secondary dissociation of $\mathrm{CH}_{3} \mathrm{CO}$ obtained by fitting the slow peak the $\mathrm{CH}_{3}$ TOF spectra of Figs. 2(a) and 2(b) is shown by the dotted curve (c) $\mathrm{P}\left(\mathrm{E}_{\mathrm{c.m}}\right.$.) derived by the TOF spectrum of $\mathrm{C}_{6} \mathrm{H}_{5} \mathrm{CH}_{3}$ of Fig. 8. The TOF spectrum of $\mathrm{C}_{6} \mathrm{H}_{5} \mathrm{CH}_{3}$ does not contain information for $\mathrm{P}\left(\mathrm{E}_{\mathrm{c.m} . \mathrm{m}}\right)$ at $\mathrm{E}_{\mathrm{c.m} . \mathrm{m}}<8 \mathrm{kcal} / \mathrm{mol}$ due to the kinematic constraint. 
spectra. This $P\left(E_{c . m}\right)$ peaks near $12 \mathrm{kcal} / \mathrm{mol}$ and has a $E_{c, m}$ onset of $34 \mathrm{kcal} / \mathrm{mol}$. The latter value is significantly lower than the thermochemical $\mathrm{E}_{\mathrm{c} . \mathrm{m}}$ threshold of $67 \mathrm{kcal} / \mathrm{mol}$. The average kinetic energy release of $13.8 \mathrm{kcal} / \mathrm{mol}$ for process $(1)$ is $\approx 20 \%$ of the total available energy.

We attempt to use the $\mathrm{P}\left(\mathrm{E}_{\mathrm{cm}}\right)$ derived from the $\mathrm{CH}_{3}$ spectrum to fit the TOF spectrum for $\mathrm{C}_{6} \mathrm{H}_{5} \mathrm{CO}$, and find that the $\mathrm{P}\left(\mathrm{E}_{\mathrm{c} \cdot \mathrm{m}}\right)$ at $\mathrm{E}_{\mathrm{c} \cdot \mathrm{m}}>15 \mathrm{kcal} / \mathrm{mol}$ [indicated by the dashed curve in Fig. 4(a)] satisfactorily fits the $\mathrm{C}_{6} \mathrm{H}_{5} \mathrm{CO}$ TOF spectrum. This observation indicates that a fraction of excited $\mathrm{C}_{6} \mathrm{H}_{5} \mathrm{CO}$ radicals initially formed with $\mathrm{E}_{\mathrm{c.m}}<15 \mathrm{kcal} / \mathrm{mol}$ [or $\mathrm{E}_{\mathrm{int}}\left(\mathrm{C}_{6} \mathrm{H}_{5} \mathrm{CO}+\mathrm{CH}_{3}\right)>52$ $\mathrm{kcal} / \mathrm{mol}$ ] by process (1) undergoes further dissociation in the time scale of the present experiment. If the internal energy distributed in $\mathrm{C}_{6} \mathrm{H}_{5} \mathrm{CO}$ and $\mathrm{CH}_{3}$ is proportional to the internal degrees of freedom, the internal energy for $\mathrm{C}_{6} \mathrm{H}_{5} \mathrm{CO}$ is expected to be $>41.6 \mathrm{kcal} / \mathrm{mol}$ at $\mathrm{E}_{\mathrm{cm}}<15$ $\mathrm{kcal} / \mathrm{mol}$. Since the $\mathrm{D}_{0}\left(\mathrm{C}_{6} \mathrm{H}_{5}-\mathrm{CO}\right)$ is $<29 \mathrm{kcal} / \mathrm{mol}$ (see Table III), excited $\mathrm{C}_{6} \mathrm{H}_{5} \mathrm{CO}$ radicals with internal excitation $>29 \mathrm{kcal} / \mathrm{mol}$ are expected to dissociate according to

$$
\mathrm{C}_{6} \mathrm{H}_{5} \mathrm{CO} \rightarrow \mathrm{C}_{6} \mathrm{H}_{5}+\mathrm{CO} \text {. }
$$

On the basis of the $\mathrm{P}\left(\mathrm{E}_{\mathrm{c} . \mathrm{m}}\right)$ 's derived from the TOF spectra of $\mathrm{CH}_{3}$ and $\mathrm{C}_{6} \mathrm{H}_{5} \mathrm{CO}$, we conclude that $\approx 50 \%$ of the primary $\mathrm{C}_{6} \mathrm{H}_{5} \mathrm{CO}$ radicals [corresponding to the shaded area in Fig. 4(a)] undergoes further dissociation according to process (6).

The TOF spectrum for $\mathrm{CH}_{3} \mathrm{CO}$ measured at $\theta_{\text {lab }}=15^{\circ}$ and a flight path of $84.5 \mathrm{~cm}$ is shown in Fig. 5(a). We have also observed the TOF spectrum for $\mathrm{CH}_{2} \mathrm{CO}$ as shown in Fig. 5(b). Figures 6(a) and 6(b) depict the TOF spectra for $\mathrm{C}_{6} \mathrm{H}_{5}$ at $\theta_{\mathrm{lab}}=15^{\circ}$ and $30^{\circ}$, respectively. The 


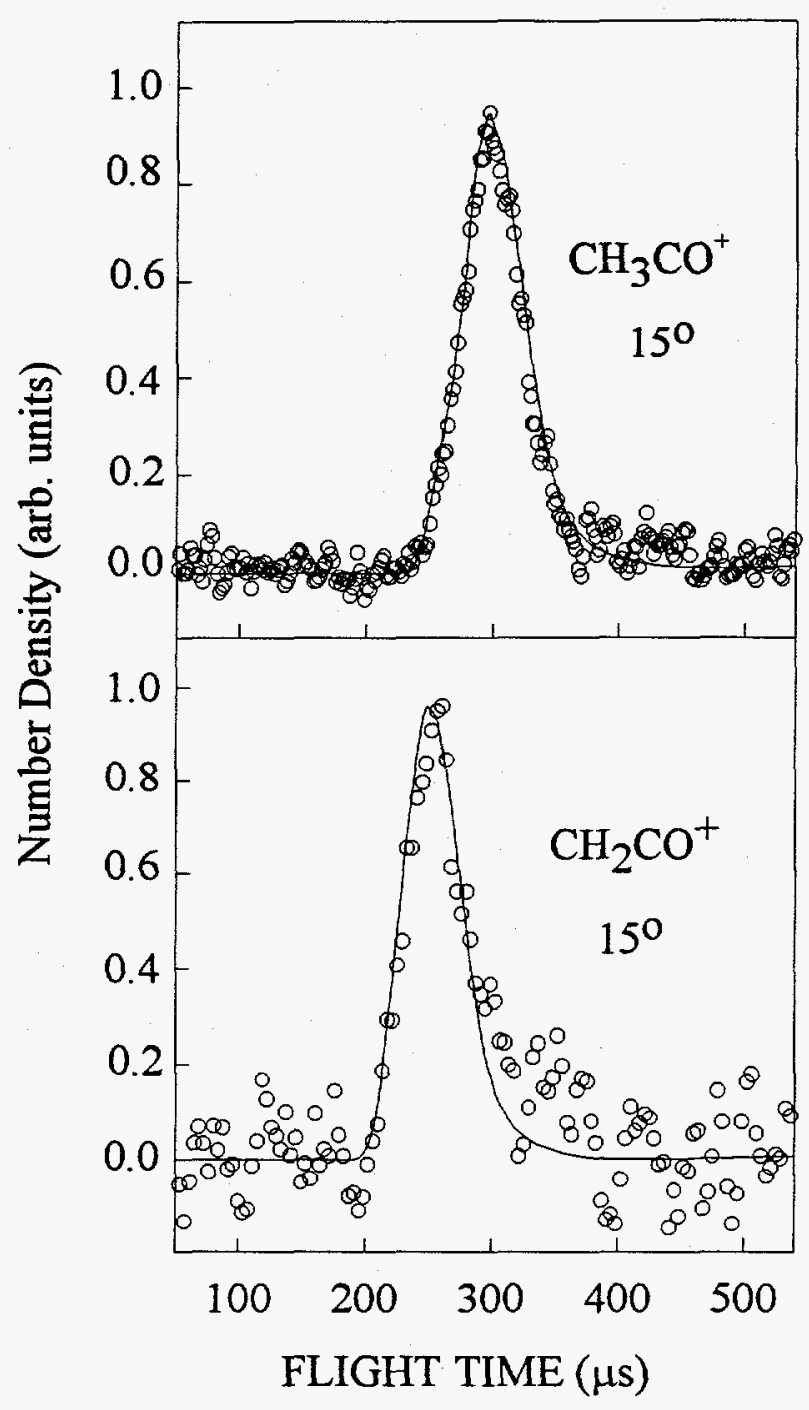

Figure $5 \mathrm{TOF}$ spectrum for (a) $\mathrm{CH}_{3} \mathrm{CO}$ and (b) $\mathrm{CH}_{2} \mathrm{CO}$ at $\theta_{\mathrm{lab}}=15^{\circ}$. The spectrum for $\mathrm{CH}_{3} \mathrm{CO}$ is measured at a flight path of $84.5 \mathrm{~cm}$. Circles represent the experimental data. 


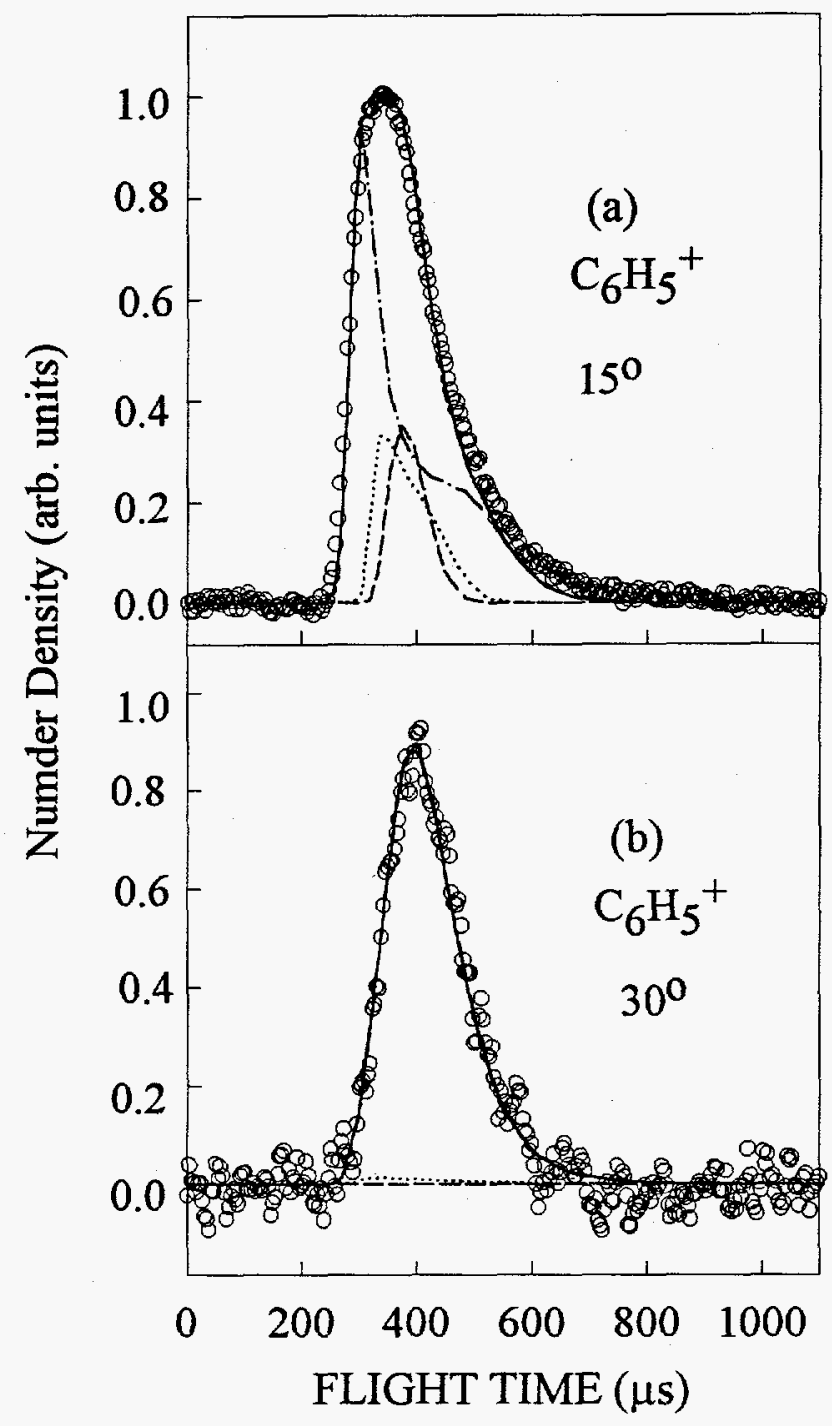

Figure 6 TOF spectra for $\mathrm{C}_{6} \mathrm{H}_{5}$ at (a) $\theta_{\mathrm{lab}}=15^{\circ}$ and (b) $\theta_{\mathrm{lab}}=30^{\circ}$. Circles represent experimental data. Contributions are shown for $\mathrm{C}_{6} \mathrm{H}_{5}$ (dot-dashed line) from process (2), $\mathrm{C}_{6} \mathrm{H}_{5} \mathrm{CO}$ (dashed line) from process (1), and $\mathrm{C}_{6} \mathrm{H}_{5}$ (dotted line) from process (6). 
observation of the $\mathrm{CH}_{3} \mathrm{CO}$ and $\mathrm{C}_{6} \mathrm{H}_{5}$ spectra indicates the occurrence of process (2). The TOF spectrum for $\mathrm{CH}_{3} \mathrm{CO}$ is used to derive the approximated $\mathrm{P}\left(\mathrm{E}_{\mathrm{cm}}\right)$ for process (2), shown as the solid curve in Fig. 4(b). The $\mathrm{P}\left(\mathrm{E}_{\mathrm{c} . \mathrm{m}}\right)$ thus obtained fits the TOF spectrum for $\mathrm{CH}_{2} \mathrm{CO}$, indicating that the $\mathrm{CH}_{2} \mathrm{CO}^{+}$signal arises from the dissociative electron ionization of $\mathrm{CH}_{3} \mathrm{CO}$.

We expect that $\mathrm{CH}_{3}{ }^{+}$fragment ions formed in the dissociative electron ionization of $\mathrm{CH}_{3} \mathrm{CO}$ [process (7)] contribute to the TOF spectra for $\mathrm{CH}_{3}$ ( Fig. 2).

$$
\mathrm{CH}_{3} \mathrm{CO}+\mathrm{e}^{-} \rightarrow \mathrm{CH}_{3}{ }^{+}+\mathrm{CO}+2 \mathrm{e}^{-}
$$

However, the $\mathrm{P}\left(\mathrm{E}_{\mathrm{cm}}\right)$ derived from the TOF spectrum of $\mathrm{CH}_{3} \mathrm{CO}$ cannot account for the slow, broad peaks shown in Figs. 2(a) and 2(b). Since $\mathrm{D}_{0}\left(\mathrm{CH}_{3}-\mathrm{CO}\right)$ is $<11 \mathrm{kcal} / \mathrm{mol}$ (see Table III), the further dissociation of some internally excited $\mathrm{CH}_{3} \mathrm{CO}$ radicals according to process (8) is expected.

$$
\mathrm{CH}_{3} \mathrm{CO} \rightarrow \mathrm{CH}_{3}+\mathrm{CO}
$$

Process (8) has been observed for acetyl radicals initially formed in the photodissociation of acetone and acetyl chloride. ${ }^{1,7}$ The approximated $\mathrm{P}\left(\mathrm{E}_{\mathrm{c.m}}\right)$ for process (2) derived from the TOF spectrum peaks at $E_{\mathrm{cm}} \approx 10.5 \mathrm{kcal} / \mathrm{mol}^{39}$ indicating that the most probable internal energy for $\mathrm{CH}_{3} \mathrm{CO}+\mathrm{C}_{6} \mathrm{H}_{5}$ is $\approx 38 \mathrm{kcal} / \mathrm{mol}$, which is $\approx 79 \%$ of the available energy. Assuming that this internal energy is partitioned according to the internal degrees of freedom of the photofragments, 
the most probable internal energy for $\mathrm{CH}_{3} \mathrm{CO}$ is estimated to be $19 \mathrm{kcal} / \mathrm{mol}$, which is above the $\mathrm{D}_{0}\left(\mathrm{CH}_{3}-\mathrm{CO}\right)$ value of $9.3 \mathrm{kcal} / \mathrm{mol}$ (see Table III). Since the portion of excited $\mathrm{CH}_{3} \mathrm{CO}$ radicals originally formed by process (2) with internal energy greater $\mathrm{D}_{0}\left(\mathrm{CH}_{3}-\mathrm{CO}\right)$ is expected to dissociate according to process (8), the true $P\left(E_{c, m}\right)$ at lower $E_{c m}$ for process (2) should be higher than that indicated by the approximated $\mathrm{P}\left(\mathrm{E}_{\mathrm{cm}}\right)$ derived by the TOF spectrum of $\mathrm{CH}_{3} \mathrm{CO}$. However, the high $\mathrm{E}_{c . m}$ portion of the approximated $\mathrm{P}\left(\mathrm{E}_{\mathrm{c} . \mathrm{m}}\right)$ based on the $\mathrm{CH}_{3} \mathrm{CO}$ spectrum represents the true $P\left(E_{c . m}\right)$ for process (2). The $E_{c . m}$ onset of $\approx 35 \mathrm{kcal} / \mathrm{mol}$ observed is more than $10 \mathrm{kcal} / \mathrm{mol}$ lower than the thermochemical $\mathrm{E}_{\mathrm{c} \cdot \mathrm{m}}$ threshold $48.5 \mathrm{kcal} / \mathrm{mol}$ for process (2).

Using the secondary $P\left(E_{c . m}\right)$ shown as the dotted curve in Fig. $4(b)$ for the dissociation process (8), we find that the slow, broad peaks observed in the TOF spectra of $\mathrm{CH}_{3}$ at $\theta_{\mathrm{lab}}=15^{\circ}$ and $30^{\circ}$ are satisfactorily accounted for by process (8) [see dotted curves in Figs 2(a) and 2(b)]. We note that the secondary $P\left(E_{c . m}\right)$ for process (8) thus obtained peaks at $6 \mathrm{kcal} / \mathrm{mol}$ and is similar to that derived in the $193 \mathrm{~nm}$ photodissociation study of acetone. ${ }^{7}$ This latter observation can be taken as support for the present attribution of the slow peaks of Figs. 2(a) and 2(b). Based on this attribution, the contribution due to the dissociative electron ionization process (7) is small [see dot-dashed curve in Figs. 2(a) and 2(b)]. The simulation of the $\mathrm{CH}_{3}$ spectra reveals that the cross sections for process (1) to (2) at $\mathrm{h} v=193 \mathrm{~nm}$ are comparable.

As a result of the kinematic constraint, $\mathrm{C}_{6} \mathrm{H}_{5} \mathrm{CO}$ cannot be observed beyond $27^{\circ}$ [see Fig. 1(a)]. Thus, $\mathrm{C}_{6} \mathrm{H}_{5}{ }^{+}$ions formed in the dissociative electron ionization process (9),

$$
\mathrm{C}_{6} \mathrm{H}_{5} \mathrm{CO}+\mathrm{e}^{-} \rightarrow \mathrm{C}_{6} \mathrm{H}_{5}^{+}+\mathrm{CO}+2 \mathrm{e}^{-}
$$


should not contribute to the TOF spectrum for $\mathrm{C}_{6} \mathrm{H}_{5}$ at $30^{\circ}$ shown in Fig. $6(\mathrm{~b})$. We find that this latter spectrum can be accounted for by the $\mathrm{P}\left(\mathrm{E}_{\mathrm{cm}}\right)$ derived from the $\mathrm{CH}_{3} \mathrm{CO}$ spectrum [Fig. 4(b)] at $\mathrm{E}_{\mathrm{cm}} \geq 16.5 \mathrm{kcal} / \mathrm{mol}$. However, the TOF spectrum for $\mathrm{C}_{6} \mathrm{H}_{5}$ at $15^{\circ}$, shown in Fig. 6(a), may contain contributions from the primary process (2), the secondary dissociation process (6), and the dissociative electron ionization process (9). The fitting due to processes (2) and (9) are fixed by the $P\left(E_{c . m}\right)$ 's of the primary processes (1) and (2). The fact that the spectrum of Fig. 6(a) cannot be fitted by processes (2) and (9) indicates the occurrence of secondary process (6). As pointed out above, the approximated $\mathrm{P}\left(\mathrm{E}_{\mathrm{c} . \mathrm{m}}\right)$ of process (2) derived from the TOF spectrum for $\mathrm{CH}_{3} \mathrm{CO}$ represents only the stable part of $\mathrm{CH}_{3} \mathrm{CO}$ formed by process (2). The complete $\mathrm{P}\left(\mathrm{E}_{\mathrm{cm}}\right)$ for process (2) should include the secondary dissociation part according to process (8). Therefore, we have adjusted the approximated $P\left(E_{c \cdot m}\right)$ at lower $E_{c \cdot m}$ values to fit the TOF spectrum for $\mathrm{C}_{6} \mathrm{H}_{5}$ at $15^{\circ}$. The best fit is achieved by taking into account contributions form process (2) (dot-dashed curve), process (6) (dotted curve), and process (9) (dashed curve). The secondary $P\left(E_{c . m}\right)$ for process (6) (dotted curve) used is shown in Fig. 4. The complete $P\left(E_{c . m}\right)$ for process (2) [Fig. 4(b)] is thus the combined dashed curve at $\mathrm{E}_{\mathrm{c} \cdot \mathrm{m}}<10.5 \mathrm{kcal} / \mathrm{mol}$ and the solid curve at $E_{c . m} \geq 10.5 \mathrm{kcal} / \mathrm{mol}$. The shaded area between the solid and dashed curve represents the portion of excited $\mathrm{CH}_{3} \mathrm{CO}(\approx 40 \%)$ undergoing further dissociation. We note that the portion of the $\mathrm{P}\left(\mathrm{E}_{\mathrm{cm}}\right)$ at $\mathrm{E}_{\mathrm{c} \cdot \mathrm{m}}<10.5 \mathrm{kcal} / \mathrm{mol}$ derived by fitting the $\mathrm{C}_{6} \mathrm{H}_{5}$ spectrum of Fig. $6(\mathrm{a})$ has considerable uncertainties. Nevertheless, the fitting of the $\mathrm{C}_{6} \mathrm{H}_{5}$ spectrum at $15^{\circ}$ is consistent with the conclusion obtained in the simulation of the TOF spectra for $\mathrm{CH}_{3}$ : the cross sections for processes (1) and (2) are comparable. 
Figures 7 (a) and 7(b) show the TOF spectra for CO observed at $\theta_{\mathrm{lab}}=15^{\circ}$ and $30^{\circ}$. In addition to contributions from the secondary dissociation processes (6) and (8), the TOF spectra for $\mathrm{CO}$ also contain contributions from the primary processes (1) and (2) due to the dissociative electron ionization processes (10) and (11), respectively.

$$
\begin{aligned}
& \mathrm{C}_{6} \mathrm{H}_{5} \mathrm{CO}+\mathrm{e}^{-} \rightarrow \mathrm{C}_{6} \mathrm{H}_{5}+\mathrm{CO}^{+}+2 \mathrm{e}^{-} \\
& \mathrm{CH}_{3} \mathrm{CO}+\mathrm{e}^{-} \rightarrow \mathrm{CH}_{3}+\mathrm{CO}^{+}+2 \mathrm{e}^{-}
\end{aligned}
$$

Contributions from processes $(1)+(10)$ (dashed line) and processes $(2)+(11)$ (dot-dashed line) are found to be small. This can be understood by the low efficiencies for $\mathrm{CO}^{+}$production in processes (10) and (11) as a result of the significantly higher $\mathrm{IE}(\mathrm{CO})$ value than those for $\mathrm{C}_{6} \mathrm{H}_{5}$ and $\mathrm{CH}_{3}{ }^{21}$ The gross features of the CO TOF spectra of Figs. $7(\mathrm{a})$ and $7(\mathrm{~b})$ can be fitted by adjusting the portions of process (6) (dot-dot-dashed line) and process (8) (dotted line).

Figure 8 shows the TOF spectrum for toluene $\left(\mathrm{C}_{6} \mathrm{H}_{5} \mathrm{CH}_{3}\right)$ at $15^{\circ}$ obtained by more than one million laser shots. The direct detection of $\mathrm{C}_{6} \mathrm{H}_{5} \mathrm{CH}_{3}$ can be taken as evidence that process 3) also occurs. Since the breakage of the $\mathrm{CH}_{3}-\mathrm{CO}$ and $\mathrm{C}_{6} \mathrm{H}_{5}-\mathrm{CO}$ bonds is compensated by the formation of the $\mathrm{C}_{6} \mathrm{H}_{5}-\mathrm{CH}_{3}$ bond (see Table I for the $\Delta_{6} \mathrm{H}^{\circ}{ }_{0}$ value of $\mathrm{C}_{6} \mathrm{H}_{5} \mathrm{CH}_{3}$ ) and an additional $\pi$-bond in $\mathrm{CO}$, the endothermicity at $0 \mathrm{~K}$ for process (3) is only $6.2 \mathrm{kcal} / \mathrm{mol}$. However, the activation energy for this dissociation process, which neccessarily involves a tight transition complex, is likely to be high. The $\mathrm{P}\left(\mathrm{E}_{\mathrm{c} . \mathrm{m}}\right)$ for process (3) derived from the TOF spectrum for $\mathrm{CH}_{3} \mathrm{C}_{6} \mathrm{H}_{5}$ is shown in Fig. $4(\mathrm{c})$. This $\mathrm{P}\left(\mathrm{E}_{\mathrm{c} . \mathrm{m}}\right)$ decreases rapidly as $\mathrm{E}_{\mathrm{c} . \mathrm{m}}$ is increased from $\mathrm{E}_{\mathrm{c} . \mathrm{m}}=8$ ( $\mathrm{kcal} / \mathrm{mol}$ toward higher $\mathrm{E}_{\mathrm{cm}}$, exhibiting the feature expected of a statistical dissociation process. 


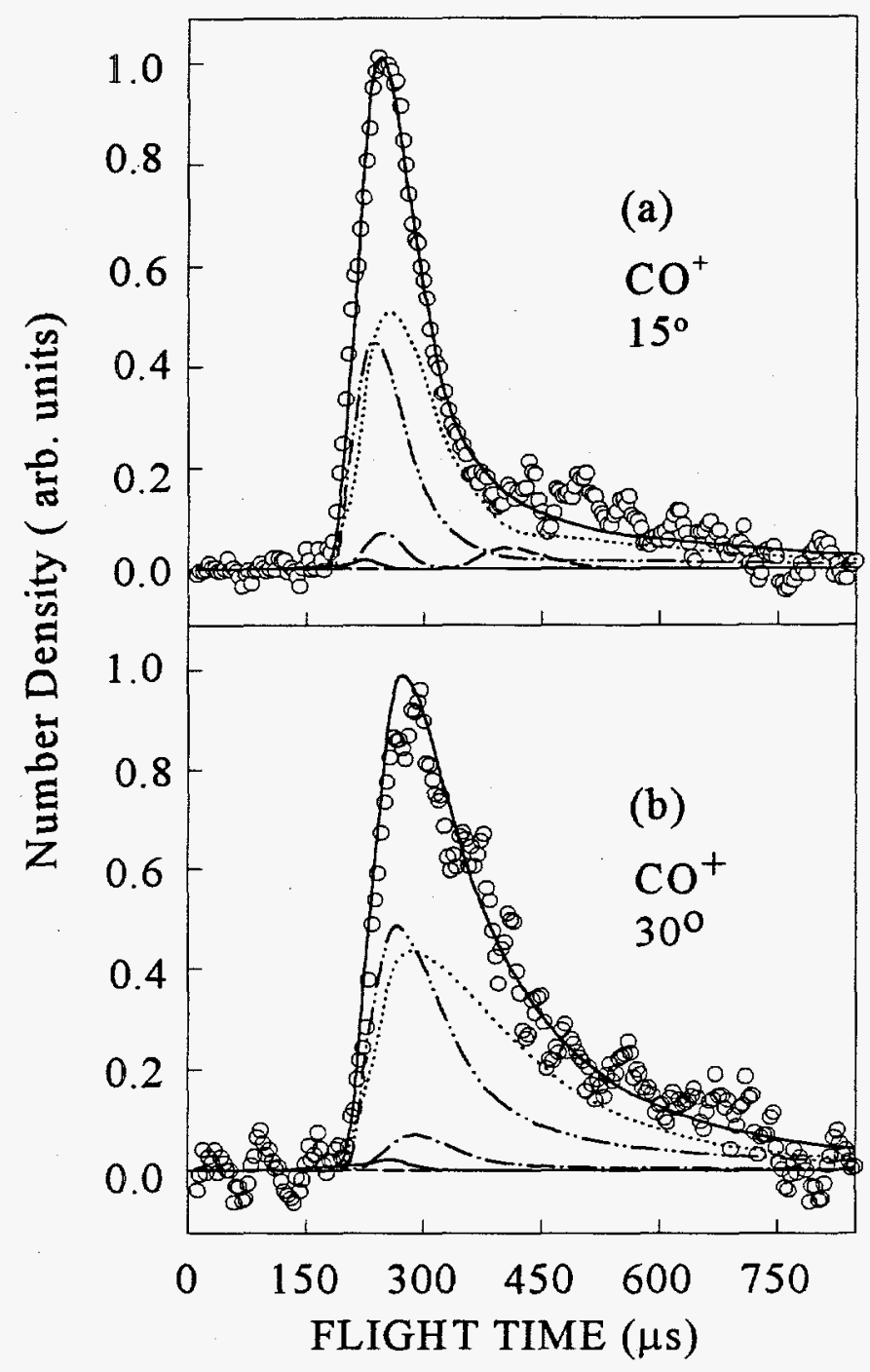

Figure 7 TOF spectra for $\mathrm{CO}$ at (a) $\theta_{\mathrm{lab}}=15^{\circ}$ and (b) $\theta_{\mathrm{lab}}=30^{\circ}$. Circles represent experimental data. Contributions are shown $\mathrm{C}_{6} \mathrm{H}_{5} \mathrm{CO}$ (dashed line) from process (1), $\mathrm{CH}_{5} \mathrm{CO}$ (dash-dotted line) from process (2), $\mathrm{CO}$ (solid line) from process (3), $\mathrm{CO}$ (dot-dot-dashed line) from process (6), and $\mathrm{CO}$ (dotted) from process (8). 


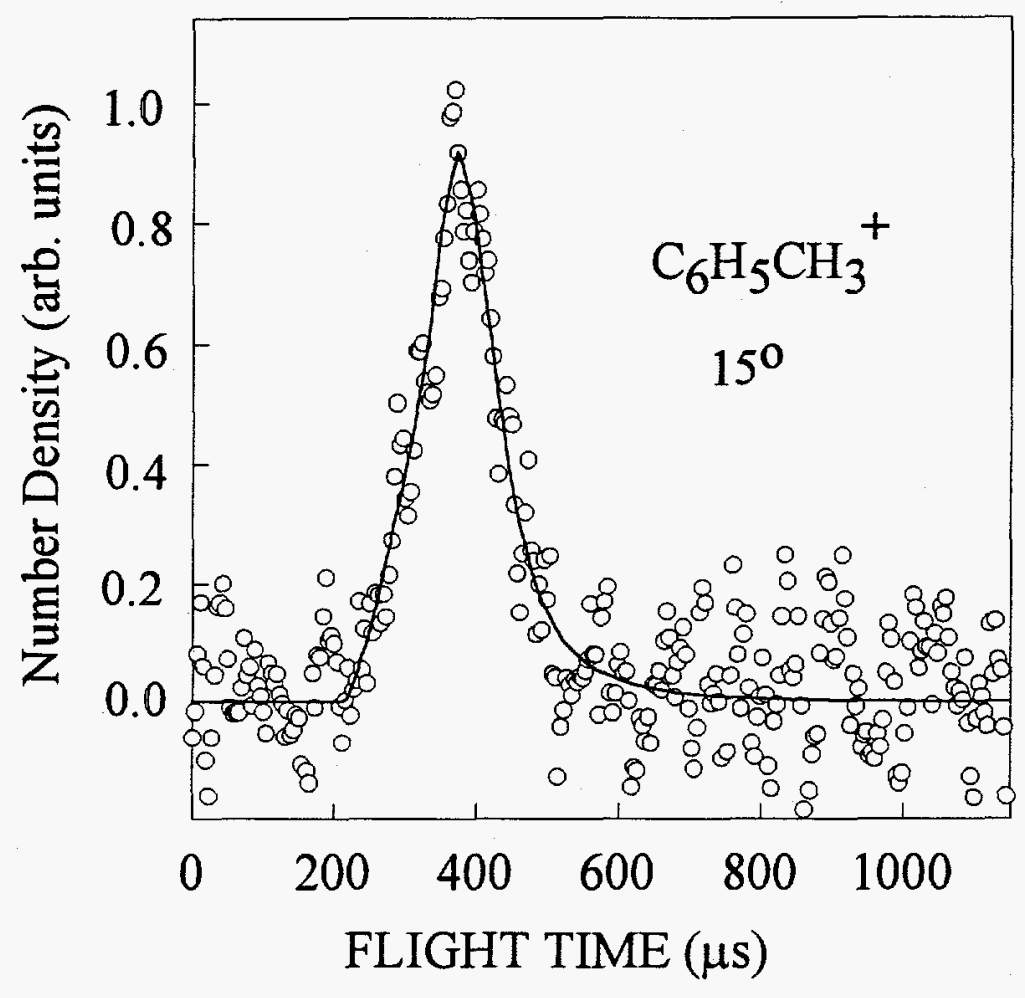

Figure $8 \mathrm{TOF}$ spectrum for $\mathrm{C}_{6} \mathrm{H}_{5} \mathrm{CH}_{3}$ at $\theta_{\text {lab }}=15^{\circ}$. Circles represent experimental data. This spectrum was obtained from more than one million laser shots. 
Due to the kinematic constraint, the TOF spectrum for $\mathrm{C}_{6} \mathrm{H}_{5} \mathrm{CH}_{3}$ at $15^{\circ}$ contains no information for the $P\left(E_{c m}\right)$ at $E_{c . m}<8 \mathrm{kcal} / \mathrm{mol}$. The $E_{c, m}$ onset for the $P\left(E_{c, m}\right)$ of process (3) is $>90 \mathrm{kcal} / \mathrm{mol}$. Comparing the observed $\mathrm{C}_{6} \mathrm{H}_{5} \mathrm{CH}_{3}, \mathrm{C}_{6} \mathrm{H}_{5}$, and $\mathrm{CH}_{3}$ signals, we estimate the cross section for process (3) is $<0.1 \%$ of those for processes (1) and (2) at $h v=193 \mathrm{~nm}$. The contribution of process (3) to the TOF spectra for $\mathrm{CO}$ at $15^{\circ}$ and $30^{\circ}$ is negligibly small [see the small solid curves in Fig. 7(a) and $7(b)]$. The statistical appearance of the $P\left(E_{c, m}\right)$ for process (3) is in consistent with the long time scale involved in $\mathrm{CH}_{3}$ rearrangement for the formation of $\mathrm{C}_{6} \mathrm{H}_{5} \mathrm{CH}_{3}$ from $\mathrm{C}_{6} \mathrm{H}_{5} \mathrm{COCH}_{3}$.

The angular distribution of the photodissociation fragments has the form: ${ }^{40,41}$

$$
\mathrm{P}(\gamma)=(1 / 4 \pi)\left[1+\beta \mathrm{P}_{2}(\cos \gamma)\right]
$$

Where $P_{2}(\cos \gamma)$ is the second Legendre polynomial and $\beta$ is the anisotropy parameter. We have measured the TOF spectra for $\mathrm{C}_{6} \mathrm{H}_{5}{ }^{+}$at polarization angles $\varepsilon=0^{\circ}, 20^{\circ}, 50^{\circ}, 70^{\circ}, 100^{\circ}$ and $150^{\circ}$ and TOF spectra for $\mathrm{CH}_{3}{ }^{+}$at $\varepsilon=0^{\circ}, 40^{\circ}, 90^{\circ}, 130^{\circ}$ (Fig. 9). Within experimental error limits, no difference in the spectra is observed. Therefore, we conclude that the photofragment angular distributions for processes (1) and (2) at hv=193 nm are isotropic. i.e., $\beta=0$. This observation is consistent with the conclusion that the $193 \mathrm{~nm}$ photodissociation of acetophenone involves a predissociation mechanism with a dissociation lifetime longer than the rotational period of photoexcited $\mathrm{C}_{6} \mathrm{H}_{5} \mathrm{COCH}_{3}$. 


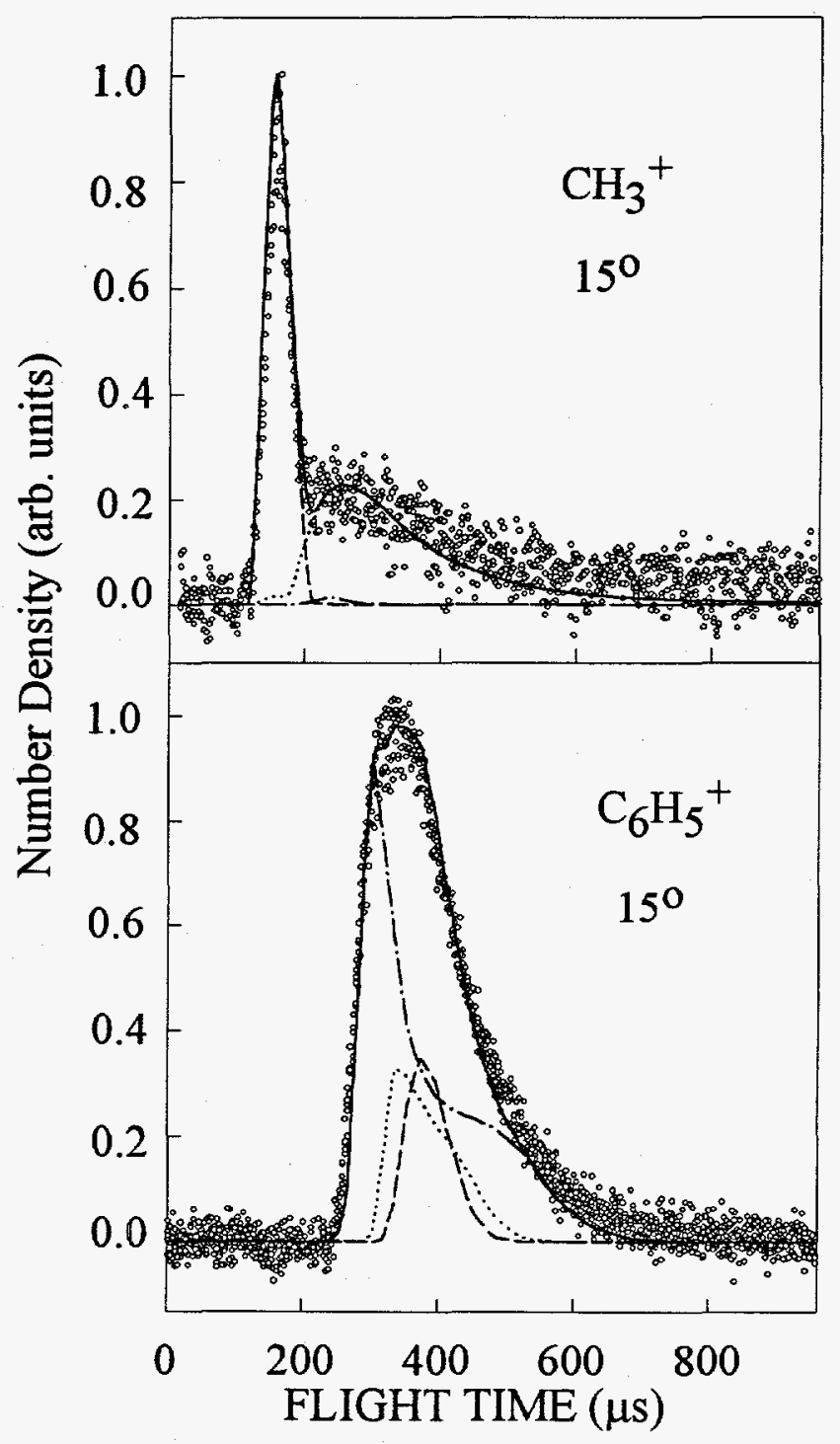

Figure 9 (a) TOF spectra for $\mathrm{CH}_{3}$ at $\theta_{\mathrm{lab}}=15^{\circ}$ and $\varepsilon=0^{\circ}, 40^{\circ}, 90^{\circ}$ and $130^{\circ}$.

(b) TOF spectra for $\mathrm{C}_{6} \mathrm{H}_{5}$ at $\theta_{\mathrm{lab}}=15^{\circ}$ and $\varepsilon=0^{\circ}, 20^{\circ}, 50^{\circ}, 70^{\circ}, 100^{\circ}$, and $150^{\circ}$. 


\section{Excitation at $248 \mathrm{~nm}$}

Upon the absorption of a $248 \mathrm{~nm}$ photon, $\mathrm{C}_{6} \mathrm{H}_{5} \mathrm{COCH}_{3}$ may dissociate according to processes (1) and (2). Since a $248 \mathrm{~nm}$ photon corresponds to an energy of $115.2 \mathrm{kcal} / \mathrm{mol}$, and the dissociation of $\mathrm{C}_{6} \mathrm{H}_{5} \mathrm{COCH}_{3}$ into $\mathrm{C}_{6} \mathrm{H}_{5}+\mathrm{CO}+\mathrm{CH}_{3}$ requires $110 \mathrm{kcal} / \mathrm{mol}$, finite dissociation of excited primary $\mathrm{C}_{6} \mathrm{H}_{5} \mathrm{CO}$ and $\mathrm{CH}_{3} \mathrm{CO}$ radicals according to processes (6) and (8) are still possible. Thus, we have searched for the TOF signals of $\mathrm{C}_{6} \mathrm{H}_{5} \mathrm{CO}, \mathrm{C}_{6} \mathrm{H}_{5} \mathrm{CH}_{3}, \mathrm{C}_{6} \mathrm{H}_{5}, \mathrm{CH}_{3} \mathrm{CO}$, $\mathrm{CH}_{3}$, and $\mathrm{CO}$ as in the $193 \mathrm{~nm}$ photodissociation experiment described above.

However, the measurements of the TOF spectra for $\mathrm{C}_{6} \mathrm{H}_{5} \mathrm{CO}, \mathrm{CH}_{3} \mathrm{CO}$, and $\mathrm{CH}_{2} \mathrm{CO}$ were unsuccessful despite a long and careful search for $\mathrm{C}_{6} \mathrm{H}_{5} \mathrm{CO}^{+}, \mathrm{CH}_{3} \mathrm{CO}^{+}$, and $\mathrm{CH}_{2} \mathrm{CO}^{+}$signals at $\theta_{\mathrm{lat}}=15^{\circ}, 20^{\circ}, 25^{\circ}$, and $30^{\circ}$. The absorption cross section of $\mathrm{C}_{6} \mathrm{H}_{5} \mathrm{COCH}_{3}$ at $248 \mathrm{~nm}$ is more than $10 \%$ of that at $193 \mathrm{~nm}^{10,15}$ Thus, the intensities for $\mathrm{C}_{6} \mathrm{H}_{5} \mathrm{CO}$ and $\mathrm{CH}_{3} \mathrm{CO}$ at $248 \mathrm{~nm}$ are much lower than those at $193 \mathrm{~nm}$. The dissociative ionization processes (7) and (9) are expected to reduce the $\mathrm{CH}_{3} \mathrm{CO}^{+}$and $\mathrm{C}_{6} \mathrm{H}_{5} \mathrm{CO}^{+}$signals. Hoping to minimize the effect of processes (7) and (9), we have also searched for the $\mathrm{CH}_{3} \mathrm{CO}^{+}$and $\mathrm{C}_{6} \mathrm{H}_{5} \mathrm{CO}^{+}$signals at ionizing electron energies lower than $75 \mathrm{eV}$. However, under such conditions, the signals for $\mathrm{CH}_{3} \mathrm{CO}^{+}$and $\mathrm{C}_{6} \mathrm{H}_{5} \mathrm{CO}^{+}$are too weak to measure the TOF spectra of $\mathrm{C}_{6} \mathrm{H}_{5} \mathrm{CO}$ and $\mathrm{CH}_{3} \mathrm{CO}$.

The TOF spectra for $\mathrm{CH}_{3}$ at $\theta_{\mathrm{lab}}=15^{\circ}, 20^{\circ}$, and $30^{\circ}$ are depicted in Figs. 10 (a), 10(b), and $10(c)$, respectively. Figures $11(a), 11(b), 11(c)$, and 11(d) show the respective TOF spectra for $\mathrm{C}_{6} \mathrm{H}_{5}$ at $\theta_{\mathrm{lab}}=10^{\circ}, 15^{\circ}, 20^{\circ}$, and $25^{\circ}$. The TOF spectra for $\mathrm{CO}$ and $\mathrm{C}_{6} \mathrm{H}_{5} \mathrm{CH}_{3}$ are shown in Figs. 12(a) and 12(b), respectively. We note that the TOF spectra for $\mathrm{C}_{6} \mathrm{H}_{5}$ at $\theta_{\mathrm{lab}}=25^{\circ}$, 

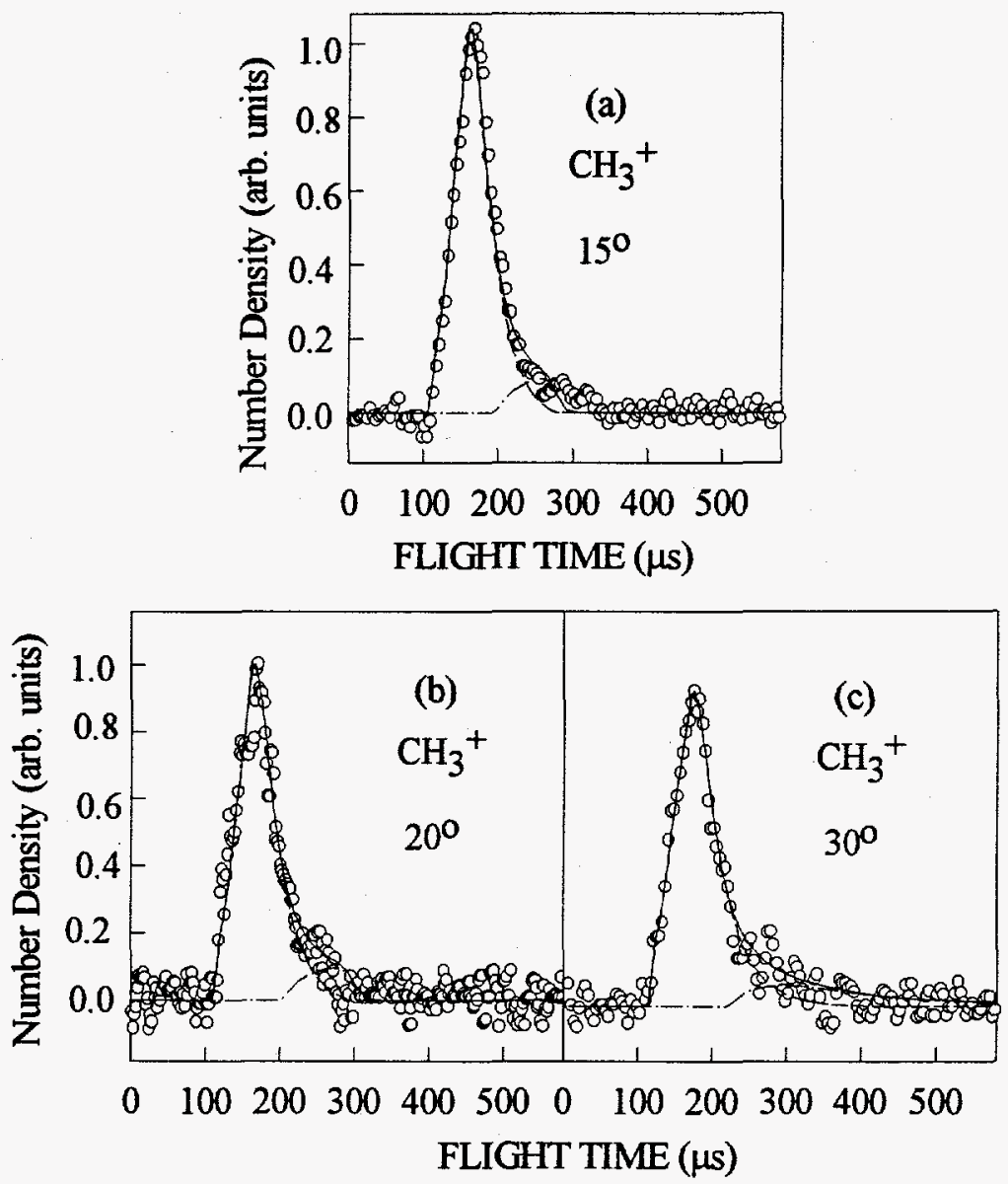

Figure 10 TOF spectra for $\mathrm{CH}_{3}$ at (a) $\theta_{\mathrm{lab}}=15^{\circ}$, (b) $\theta_{\mathrm{lab}}=20^{\circ}$, and (c) $\theta_{\mathrm{lab}}=30^{\circ}$. Circles represent experimental data. Contributions are shown for $\mathrm{CH}_{3}$ (dashed curve) from process (1) and $\mathrm{CH}_{3} \mathrm{CO}$ (dot-dashed curve) from process (2). 


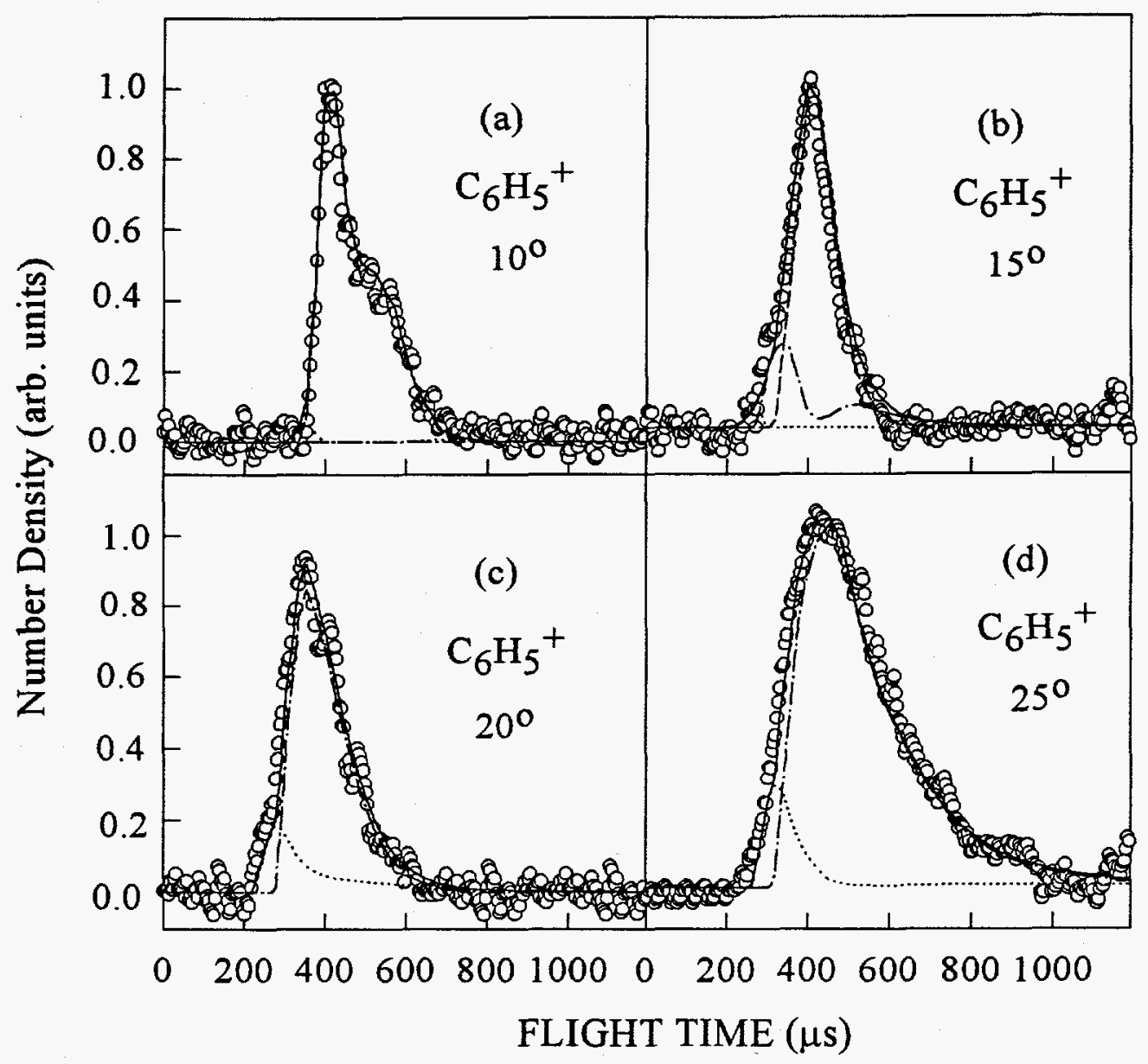

Figure 11 TOF spectra for $\mathrm{C}_{6} \mathrm{H}_{5}$ at (a) $\theta_{\mathrm{lab}}=10^{\circ}$, (b) $\theta_{\mathrm{lab}}=15^{\circ}$, (c) $\theta_{\mathrm{lab}}=20^{\circ}$, and (d) $\theta_{\mathrm{lab}}=$ $25^{\circ}$. The TOF spectrum for $\mathrm{C}_{6} \mathrm{H}_{5}$ at $\theta_{\mathrm{lab}}=25^{\circ}$ was obtained from more than one million laser shots. Circles represent experimental data. Contributions are shown for $\mathrm{C}_{6} \mathrm{H}_{5} \mathrm{CO}$ (dashed curve) from process (1), $\mathrm{C}_{6} \mathrm{H}_{5}$ (dot-dash curve) from process (2), and $\mathrm{C}_{6} \mathrm{H}_{5} \mathrm{CH}_{3}$ (dotted curve) process (3). 


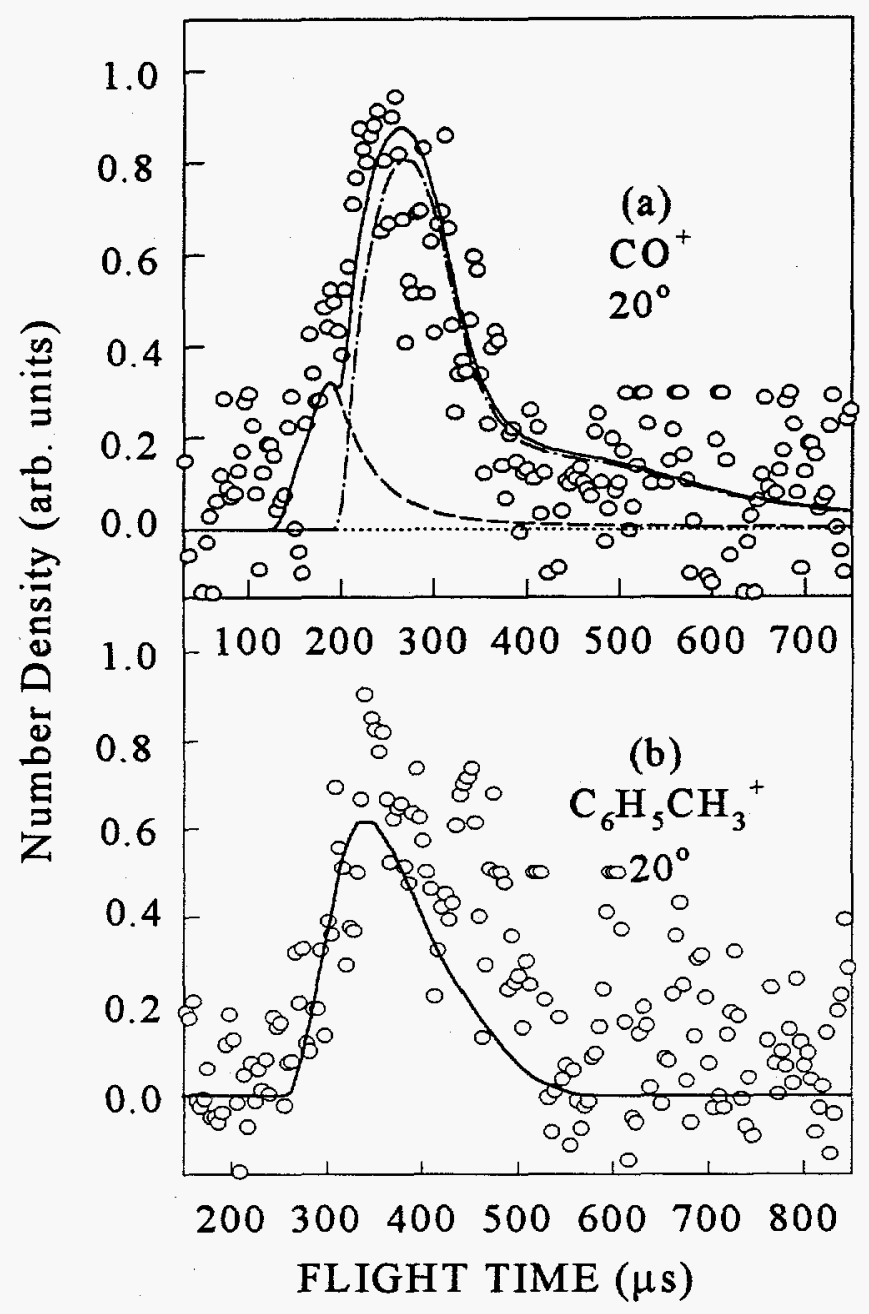

Figure 12 (a) TOF spectrum for $\mathrm{CO}$ at $\theta_{\mathrm{lab}}=20^{\circ}$. Circles represent experimental data. Contributions are shown from $\mathrm{CH}_{3} \mathrm{CO}$ (dot-dashed line) formed in process (2) and $\mathrm{CO}$ (dashed line) from process (3). (b) TOF spectrum for $\mathrm{C}_{6} \mathrm{H}_{5} \mathrm{CH}_{3}$ at $\theta_{\text {lab }}=20^{\circ}$. Circles represent experimental data. Both spectra were obtained from more than one million laser shots. 
$\mathrm{C}_{6} \mathrm{H}_{5} \mathrm{CH}_{3}$ at $\theta_{\mathrm{lab}}=20^{\circ}, \mathrm{CO}$ at $\theta_{\mathrm{lab}}=20^{\circ}$ result from the accumulation of more than one million laser shots.

Because of the kinematic constraint, $\mathrm{C}_{6} \mathrm{H}_{5} \mathrm{CO}$ produced by process (1) cannot be observed at $\theta_{\mathrm{lab}}>20^{\circ}$ [see Fig. 1(b)]. Thus, the translational energy distribution for process (2) at $248 \mathrm{~nm}$ can be derived from the TOF spectrum for $\mathrm{C}_{6} \mathrm{H}_{5}$ at $\theta_{\mathrm{lab}}=25^{\circ}$. However, in this spectrum a very fast onset appears as a shoulder, which cannot be due to process (2) based on the known $\mathrm{D}_{0}\left(\mathrm{C}_{6} \mathrm{H}_{5}-\mathrm{COCH}_{3}\right)$. We have attributed this to $\mathrm{C}_{6} \mathrm{H}_{5}{ }^{+}$formed in the dissociative electron ionization of $\mathrm{C}_{6} \mathrm{H}_{5} \mathrm{CH}_{3}$. The $\mathrm{P}\left(\mathrm{E}_{\mathrm{c} . \mathrm{m}}\right)$ for process (2) at $\mathrm{h} \nu=248 \mathrm{~nm}$ derived from the TOF spectrum for $\mathrm{C}_{6} \mathrm{H}_{5}$ at $25^{\circ}$ is shown in Fig. 13(b), which increases monotonically as $\mathrm{E}_{\mathrm{c} . \mathrm{m}}$ is decreased from the onset at $E_{c . m} \approx 19 \mathrm{kcal} / \mathrm{mol}$ to $E_{c . m}=6 \mathrm{kcal} / \mathrm{mol}$. Due to the overlap with the $\mathrm{C}_{6} \mathrm{H}_{5}{ }^{+}$signal from $\mathrm{C}_{6} \mathrm{H}_{5} \mathrm{CH}_{3}$, the $\mathrm{E}_{c \cdot m}$ onset for the $\mathrm{P}\left(\mathrm{E}_{\mathrm{c} \cdot \mathrm{m}}\right)$ of process (2) cannot be determined. The onset for the $\mathrm{P}\left(\mathrm{E}_{\mathrm{c.m} . \mathrm{m}}\right)$ of Fig. $13(\mathrm{~b})$ is fixed by the known $\mathrm{D}_{0}\left(\mathrm{C}_{6} \mathrm{H}_{5}-\mathrm{COCH}_{3}\right)$ of $99.5 \mathrm{kcal} / \mathrm{mol}$ and the estimated thermal energy of $\approx 4.8 \mathrm{kc} / \mathrm{mol}$ for parent $\mathrm{C}_{6} \mathrm{H}_{5} \mathrm{COCH}_{3}$. The spectrum for $\mathrm{C}_{6} \mathrm{H}_{5}$ at $25^{\circ}$ provides information only about the $P\left(E_{c . m}\right)$ at $E_{c . m} \geq 6 \mathrm{kcal} / \mathrm{mol}$. As shown in the analysis below, the $\mathrm{C}_{6} \mathrm{H}_{5}{ }^{+}$signal observed at $\theta_{1 \mathrm{lab}} \leq 15^{\circ}$ results overwhelmingly from the dissociative electron ionization of $\mathrm{C}_{6} \mathrm{H}_{5} \mathrm{CO}$, i.e., processes (1) + (9). Thus, the TOF spectrum for $\mathrm{C}_{6} \mathrm{H}_{5}$ at smaller $\theta_{\mathrm{lab}}$ 's does not provide reliable information about the $\mathrm{P}\left(\mathrm{E}_{\mathrm{c} . \mathrm{m}}\right)$ for process (2) at $\mathrm{E}_{\mathrm{c} . \mathrm{m}}<6$ $\mathrm{kcal} / \mathrm{mol}$.

On the basis of the $\mathrm{P}\left(\mathrm{E}_{\mathrm{c} . \mathrm{m}}\right)$ for process (2) shown in Fig. 13(b), we conclude that the $\mathrm{CH}_{3}{ }^{+}$signal originating from the dissociative electron ionization of $\mathrm{CH}_{3} \mathrm{CO}$ [process (7)] contributes only a small component to the tail of the $\mathrm{CH}_{3}$ spectra of Figs. 10(a)-10(c). Thus, the $P\left(E_{c . m}\right)$ for process (1) can be reliably determined from the TOF spectra of $\mathrm{CH}_{3}$. The $\mathrm{P}\left(\mathrm{E}_{\mathrm{c}, \mathrm{m}}\right)$ of 


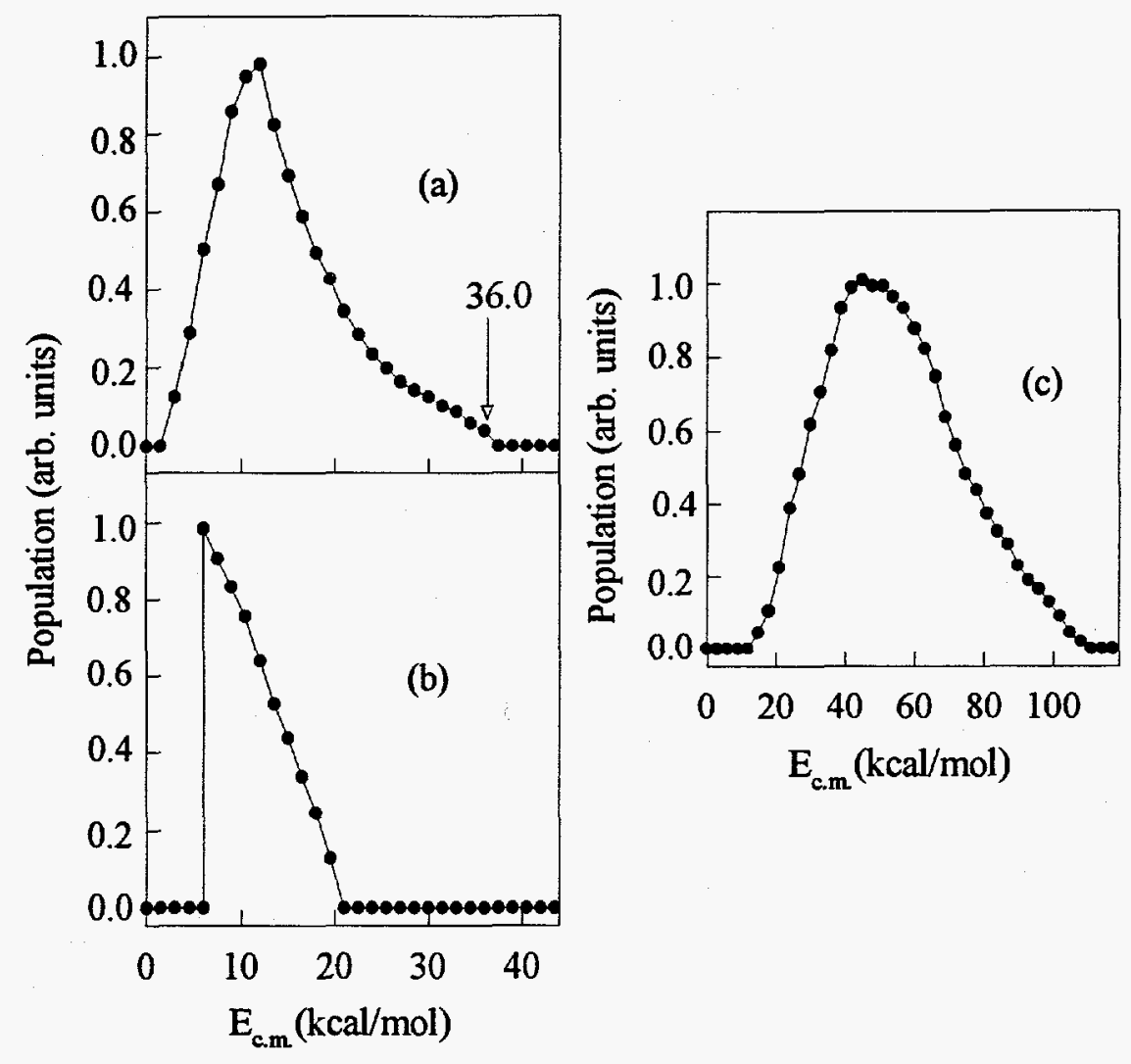

Figure 13 (a) $P\left(E_{c . m}\right)$ for process (1) derived by fitting TOF spectra for $\mathrm{CH}_{3}$.

(b) $\mathrm{P}\left(\mathrm{E}_{\text {c.m. }}\right)$ for process (2) derived by fitting the TOF spectra for $\mathrm{C}_{6} \mathrm{H}_{5}$.

(c) $\mathrm{P}\left(\mathrm{E}_{\mathrm{c.m}}\right)$ for process (3) derived by fitting the TOF spectra for $\mathrm{C}_{6} \mathrm{H}_{5} \mathrm{CH}_{3}$. 
process (1) thus determined is shown in Fig. 13(a), and peaks near $12 \mathrm{kcal} / \mathrm{mol}$. The average $E_{\mathrm{cm}}$ energy release is $14.6 \mathrm{kcal} / \mathrm{mol}$, which corresponds to $42 \%$ of the available energy of $\approx 35$ $\mathrm{kcal} / \mathrm{mol}$. The $E_{c, m}$ onset for the $P\left(E_{c, m}\right)$ of process (1) is $36.0 \pm 1.5 \mathrm{kcal} / \mathrm{mol}$. Since this experiment uses a nozzle temperature of $130^{\circ} \mathrm{C}(403 \mathrm{~K})$, the onset observed here is affected by the hot band effect. Without consideration of the hot band effect, we determine a lower bound of $79.3 \mathrm{kcal} / \mathrm{mol}$ for $\mathrm{D}_{0}\left(\mathrm{C}_{6} \mathrm{H}_{5} \mathrm{CO}-\mathrm{CH}_{3}\right)$. Using the $\mathrm{HF} / 6-31 \mathrm{G}$ vibrational frequencies, the thermal energy for $\mathrm{C}_{6} \mathrm{H}_{5} \mathrm{COCH}_{3}$ at $403 \mathrm{~K}$ is estimated to be $9.5 \mathrm{kcal} / \mathrm{mol}$. Thus, the true $\mathrm{D}_{0}\left(\mathrm{C}_{6} \mathrm{H}_{5} \mathrm{CO}\right.$ $\mathrm{CH}_{3}$ ) value should fall in the range of $79.3-88.8 \mathrm{kcal} / \mathrm{mol}$. As mentioned above, we estimate that the effective temperature for $\mathrm{C}_{6} \mathrm{H}_{5} \mathrm{COCH}_{3}$ after the mild beam expansion is in the range of 250$350 \mathrm{~K}$, corresponding to a thermal energy range of $4.2-7.4 \mathrm{kcal} / \mathrm{mol}$. Taking into account the thermal energy for $\mathrm{C}_{6} \mathrm{H}_{5} \mathrm{COCH}_{3}$, we arrive at a value of $85.0 \pm 2.2 \mathrm{kcal} / \mathrm{mol}$ for $\mathrm{D}_{0}\left(\mathrm{C}_{6} \mathrm{H}_{5} \mathrm{CO}_{-} \mathrm{CH}_{3}\right)$. The uncertainties of $\pm 2.2 \mathrm{kcal} / \mathrm{mol}$ given for $\mathrm{D}_{0}\left(\mathrm{C}_{6} \mathrm{H}_{5} \mathrm{CO}-\mathrm{CH}_{3}\right)$ include the uncertainties of the $\mathrm{E}_{\mathrm{c} . \mathrm{m}}$ onset and the possible spread in the thermal energy of the parent $\mathrm{C}_{6} \mathrm{H}_{5} \mathrm{COCH}_{3}$. The $\mathrm{D}_{0}\left(\mathrm{C}_{6} \mathrm{H}_{5} \mathrm{CO}-\mathrm{CH}_{3}\right)$ value obtained here is between the literature value of $80.7 \mathrm{kcal} / \mathrm{mol}$ and the theoretical value of $85.1 \mathrm{kcal} / \mathrm{mol}$ (see Table III). Using $\mathrm{D}_{0}\left(\mathrm{C}_{6} \mathrm{H}_{5} \mathrm{CO}-\mathrm{CH}_{3}\right)=85.0 \pm 2.2 \mathrm{kcal} / \mathrm{mol}$ determined here, together with the known $\Delta_{\mathrm{f}} \mathrm{H}^{\circ}\left(\mathrm{C}_{6} \mathrm{H}_{5} \mathrm{COCH}_{3}\right)=-15.9 \pm 0.4 \mathrm{kcal} / \mathrm{mol}$ and $\Delta_{\mathrm{f}} \mathrm{H}_{0}^{\circ}\left(\mathrm{CH}_{3}\right)=35.8 \pm 0 . \mathrm{kcal} / \mathrm{mol}\left(\right.$ see Table I), we obtain $\Delta_{\mathrm{f}} \mathrm{H}_{0}^{\circ}\left(\mathrm{C}_{6} \mathrm{H}_{5} \mathrm{CO}\right)=33.3 \pm 2.2$ $\mathrm{kcal} / \mathrm{mol}$, which is in excellent agreement with the G2(MP2, SVP) prediction of 32.5 $\mathrm{kcal} / \mathrm{mol}$ and the value of $33.9 \pm 0.4 \mathrm{kcal} / \mathrm{mol}$ calculated based on the selected set of isodesmic reactions (see Table I and reactions v-xi in Table II). 
The $P\left(E_{c m}\right)$ 's for process (1) and (2) of Figs. 13(a) and 13(b) have been used successfully to fit the TOF spectra for $\mathrm{C}_{6} \mathrm{H}_{5}$ at $\theta_{1 \mathrm{lab}}=10^{\circ} 15^{\circ}$, and $20^{\circ}$ [Figs. 11(a), 11(b), and 11c)]. The TOF spectrum for $\mathrm{C}_{6} \mathrm{H}_{5}$ at $\theta_{\text {lab. }}=20^{\circ}$ is mostly due to process (2), with minor contribution from process (3), whereas the TOF spectra for $\mathrm{C}_{6} \mathrm{H}_{5}$ at $\theta_{\mathrm{bb}}=10^{\circ}$ and $15^{\circ}$ are largely due to process (1), with minor contribution from process (2). We note that the contribution of process (2) to the TOF spectrum for $\mathrm{C}_{6} \mathrm{H}_{5}$ at $\theta_{\mathrm{lab}}=15^{\circ}$ has a bimodal structure, which results from the forward and backward scattered components of the $\mathrm{C}_{6} \mathrm{H}_{5}$ fragments.

The simulation of the TOF spectra for $\mathrm{CH}_{3}$ at $\theta_{\text {lab. }}=15^{\circ}, 20^{\circ}$ and $25^{\circ}$ [Figs. 10(a), 10(b), and 10(c)] shows that the branching ratio of process (2) to process (1) is small at $248 \mathrm{~nm}$. This ratio can also be estimated from the simulation of the TOF spectrum for $\mathrm{C}_{6} \mathrm{H}_{5}$ at $\theta_{\mathrm{lab}}=10^{\circ}$ [Fig. 11(a)]. As we have shown in a previous photodissociation study of $\mathrm{CS}_{2}$, ${ }^{25}$ the photofragments resulting from photodissociation of dimmers and clusters are mainly confined to small $\theta_{\mathrm{lab}}$ values because of kinematic constraints. In order to avoid the influence of dimers and clusters on the TOF measurement at $10^{\circ}$, we have decreased the stagnation pressure of $\mathrm{C}_{6} \mathrm{H}_{5} \mathrm{COCH}_{3}$ to 260 Torr to reduce the effect of supersonic cooling. Under such molecular beam expansion conditions, no signals from electron ionization of dimers and clusters of $\mathrm{C}_{6} \mathrm{H}_{5} \mathrm{COCH}_{3}$ are observed at $\theta_{\text {lab. }}=10^{\circ}$. As shown in Fig. 11(a), the simulation indicates that the TOF spectrum for $\mathrm{C}_{6} \mathrm{H}_{5}$ at $\theta_{\mathrm{lab} .}=10^{\circ}$ is predominantly accounted for by process (1). On the basis of the simulation of the $\mathrm{CH}_{3}$ and $\mathrm{C}_{6} \mathrm{H}_{5}$ TOF spectra, we estimate that the branching ratio of process (2) to process (1) is $\approx 0.01$. 
The $\mathrm{P}\left(\mathrm{E}_{\mathrm{c} \mathrm{m}}\right)$ for process (3) at $\mathrm{hv}=248 \mathrm{~nm}$ derived from the TOF spectrum for $\mathrm{C}_{6} \mathrm{H}_{5} \mathrm{CH}_{3}$ [Fig. 12(b)] is depicted in Fig.13(c). This $\mathrm{P}\left(\mathrm{E}_{\mathrm{cm}}\right)$ is different from that obtained at $\mathrm{hv}=193 \mathrm{~nm}$ [Fig. 4(c)]. The observed $E_{c . m}$ onset of $\approx 106 \mathrm{kcal} / \mathrm{mol}$ for the $P\left(E_{c . m}\right)$ of Fig. $13(c)$ is close to the thermochemical threshold of $109 \mathrm{kcal} / \mathrm{mol}$ for process (3) at $\mathrm{hv}=248 \mathrm{~nm}$. The $\mathrm{P}\left(\mathrm{E}_{\mathrm{cm}}\right)$ is nearly symmetrical about the maximum at $\mathrm{E}_{\mathrm{cm} . \mathrm{m}} \approx 50 \mathrm{kcal} / \mathrm{mol}$, indicating that the available energy of 109 $\mathrm{kcal} / \mathrm{mol}$ for process (3) is about equally partitioned into internal and translational energies of the photofragments. This $P\left(E_{c . m}\right)$ of Fig. 13(c) has been used satisfactorily to fit the fast shoulder observed in the TOF spectra for $\mathrm{C}_{6} \mathrm{H}_{5}$ at $\theta_{\text {lab }}=20^{\circ}$ and $25^{\circ}$ [Figs. 11(c) and 11(d)]. The simulation of the $\mathrm{C}_{6} \mathrm{H}_{5}$ TOF spectra indicates that the branching ratio for process (2) to process (3) is $\approx 0.08$ without considering the difference in the efficiency for the formation of $\mathrm{C}_{6} \mathrm{H}_{5}{ }^{+}$by electron ionization of $\mathrm{C}_{6} \mathrm{H}_{5}$ and that by the dissociative electron ionization of $\mathrm{C}_{6} \mathrm{H}_{5} \mathrm{CH}_{3}$.

Due to the high $\mathrm{N}_{2}$ background in the ionizer of the QMS, the signal-to-noise ratio is poor for the CO TOF spectrum observed at $\theta=20^{\circ}$ [Fig. 14(a)] even after accumulating more than one million laser shots. According to dissociative electron ionization processes (10) and (11), $\mathrm{CO}^{+}$ from the primary photofragments $\mathrm{C}_{6} \mathrm{H}_{5} \mathrm{CO}$ and $\mathrm{CH}_{3} \mathrm{CO}$ should also contribute to the $\mathrm{CO} T \mathrm{TOF}$ spectrum. However, as pointed out above, the $\mathrm{CO}^{+}$signals from processes (10) and (11) are expected to be small because of the high ionization energy of $\mathrm{CO}$. The simulation of the CO TOF spectrum at $\theta=20^{\circ}$ shows that the major contribution is by processes $(2)+(11)$ (dot-dashed curve), and process (3) contributes as a smaller fast peak (dashed curve). We note that process (1) cannot be seen at $\theta=20^{\circ}$ due to the kinematic constraints. 
The angular distribution for process (1) is probed by measuring the TOF spectrum for $\mathrm{C}_{6} \mathrm{H}_{5}$ at $\theta_{1 \mathrm{lab}}=12^{\circ}$ and $\varepsilon=10^{\circ}, 30^{\circ}, 50^{\circ}, 70^{\circ}, 90^{\circ}, 100^{\circ}, 130^{\circ}, 150^{\circ}$, and $170^{\circ}$ (see Fig. 14). These spectra are essentially identical, indicating that the photofragment angular distribution for process (1) is isotropic, i.e., $\beta=0$. Again, this observation indicates that the dissociation lifetime of the excited state of $\mathrm{C}_{6} \mathrm{H}_{5} \mathrm{COCH}_{3}$ involved is longer than that of the rotational period, and that a predissociation mechanism is operative for process (1) at $h v=248 \mathrm{~nm}$. Since process (2) is a minor channel, the low TOF signal for $\mathrm{CH}_{3}$ makes it difficult to measure the photofragment angular distribution for process (2).

\section{Conclusion}

The TOF spectra for $\mathrm{CH}_{3}$ and $\mathrm{C}_{6} \mathrm{H}_{5}$ resulting from the $193 \mathrm{~nm}$ and $248 \mathrm{~nm}$ photofragmentation of $\mathrm{C}_{6} \mathrm{H}_{5} \mathrm{COCH}_{3}$ has been measured. At $193 \mathrm{~nm}$, processes (1) and (2) occur with comparable cross sections. The cross section for process (3) at $193 \mathrm{~nm}$ is estimated to be $<$ $0.1 \%$ of those for processes (1) and (2). Approximately $30-50 \%$ of the $\mathrm{CH}_{3} \mathrm{CO}$ and $\mathrm{C}_{6} \mathrm{H}_{5} \mathrm{CO}$ radicals initially formed at $193 \mathrm{~nm}$ by processes (1) and (2) are found to undergo further dissociation according to processes (6) and (8). At $248 \mathrm{~nm}$, process (1) is overwhelmingly the dominant channel. The branching ratios for process (1) : process (2) : process (3) are estimated as 1.0: $0.01: 0.0008$. The energy releases for these dissociation processes have also been determined. The photofragment angular distributions for these processes are isotropic, possibly indicative of a predissociative mechanism. From the $E_{c, m}$ onset for process (2) at $248 \mathrm{~nm}$, we determine $\mathrm{D}_{0}\left(\mathrm{C}_{6} \mathrm{H}_{5} \mathrm{CO}-\mathrm{CH}_{3}\right)=8.5 \pm 2.2 \mathrm{kcal} / \mathrm{mol}$ and $\Delta_{\mathrm{f}} \mathrm{H}^{\circ}{ }_{0}\left(\mathrm{C}_{6} \mathrm{H}_{5} \mathrm{CO}\right)=33.3 \pm 2.2 \mathrm{kcal} / \mathrm{mol}$. 


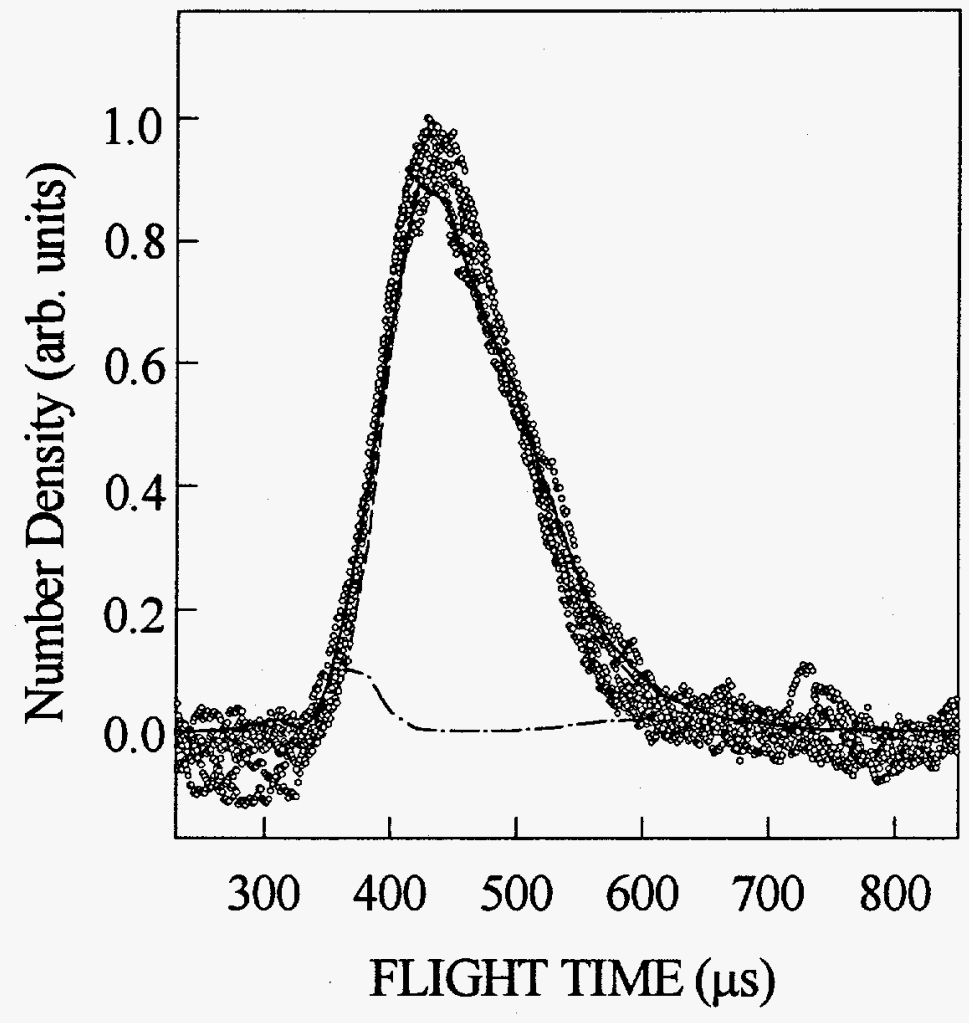

Figure 14 TOF spectra for $\mathrm{C}_{6} \mathrm{H}_{5}$ at $\theta_{\mathrm{lab}}=12^{\circ}$ and $\varepsilon=10^{\circ}, 30^{\circ}, 50^{\circ}, 70^{\circ}, 90^{\circ}, 110^{\circ}, 130^{\circ}$, $150^{\circ}$, and $170^{\circ}$. 
We have also conducted an $a b$ initio study of the energetics for $\mathrm{C}_{6} \mathrm{H}_{5} \mathrm{CO}$, and $\mathrm{C}_{6} \mathrm{H}_{5}$ formed in processes (1) and (2) using the G2-type procedures together with isodesmic reaction scheme. The theoretical value $\Delta_{\mathrm{f}} \mathrm{H}_{0}^{\circ}\left(\mathrm{C}_{6} \mathrm{H}_{5} \mathrm{CO}\right)=33.9 \pm 1.3 \mathrm{kcal} / \mathrm{mol}$ is in good accord with the experimental result of the present study. The theoretical values $\Delta_{\mathrm{f}} \mathrm{H}_{0}^{\circ}\left(\mathrm{C}_{6} \mathrm{H}_{5}\right)=87.6 \pm 1.0$ $\mathrm{kcal} / \mathrm{mol}$ and $\Delta_{\mathrm{f}} \mathrm{H}^{\circ}{ }_{0}\left(\mathrm{C}_{6} \mathrm{H}_{5} \mathrm{CO}\right)=33.9 \pm 1.3 \mathrm{kcal} / \mathrm{mol}$ indicate the literature $\Delta_{\mathrm{f}} \mathrm{H}^{\circ}{ }_{0}$ values for $\mathrm{C}_{6} \mathrm{H}_{5} \mathrm{CO}$ and $\mathrm{C}_{6} \mathrm{H}_{5}$ are likely high by $3-4 \mathrm{kcal} / \mathrm{mol}$.

\section{References}

1. S. W. North, D. A. Blank, J. D. Gezelter, C. A. Longfellow, and Y. T. Lee, J. Chem. Phys. $102,4447(1995)$.

2. S. K. Kim, S. Pederson, and A. H. Zewail, J. Chem. Phys. 103, 477 (1995).

3. K. A. Trentelman, S. H. Kable, D. B. Moss, and P. L. Houston, J. Chem. Phys. 91,7498 (1989).

4. P. D. Lightfoot, S.P.Kirwan, and M.J.Pilling, J.Phys.Chem. 92, 4938, (1988)

5. H. Li, Q. Li, W. Mao, Q. Zhu, and F. Kong, J. Chem. Phys. 106, 5943 (1997).

6. P. W. Kash, G. C. G.Waschewsky, R. E. Morss, and L. J. Butler, J.Chem. Phys. 100, 3463(1994)

7. S. W. North, D. A. Blank, and Y. T. Lee, Chem. Phys. Lett. 224, 38 (1994).

8. S. Deshmukh and W. P. Hess, J. Chem. Phys. 100, 6429 (1994).

9. S. Deshmukh, J. D. Myers, S. S. Xantheas, and W. P. Hess, J. Phys. Chem. 98, 12535 (1994).

10. J. G. Calvert and J. N. Pitts, "Photochemistry" (Wiley, New York, 1966).

11. N. C. Baird and H. B. Kathpal, Can. J. Chem. 55, 863 (1977). 
12. W. C. Brider, “Combustion Chemistry” (Springer, New York, 1984).

13. H. H. Glazebrook and T G. Pearson, J. Chem. Soc. 589 (1939).

14. F. J. Duncan and A. F. Trotman-Dickenson, J. Chem. Soc. 4672 (1962).

15. M. Berger and C. Steel, J. Am. Chem. Soc. 97, 4817 (1975).

16. L. A. Curtiss, K. Raghavachari, G. W. Trucks, and J. A. Pople, J. Chem. Phys. 94, 7221 (1991).

17. L. A. Curtiss, K. Raghavachari, and J. A. Pople, J. Chem. Phys. 98, 1293 (1993).

18. B. J. Smith and L. Radom, J. Phys. Chem. 99, 6468 (1995).

19. Y. S. Cheung, Y.-J. Chen, C.-L. Liao, C. Y. Ng, and W.-K. Li, J. Amer. Chem. Soc., 117, 9725 (1995).

20. C. W. Bauschlicher, Jr., J. Phys. Chem. 98, 2564 (1994).

21. S. G. Lias, J. E. Bartmess, J. F. Liebman, . L. Holmes, R. D. Levin, and W. G. Mallard, J. Phys. Chem. Ref. Data 17, Suppl. No. 1 (1988).

22. J. T. Niiranen, D. Gutman, and L. N. Krasnoperov, J. Phys. Chem. 96, 5881 (1992).

23. R. K. Solly and S. W. Benson, J. Am. Chem. Soc. 93, 1592 (1971).

24. S. W. Benson, "Thermochemical Kinetics" (Wiley, new York, 1968).

25. W.-B Tzeng, H.-M Yin, W.-Y. Leung, J.-Y. Luo, S. Nourbakhsh, G.D.Flesch and C. Y. Ng; J. Chem. Phys. 88, 1658 (1988).

26. H.-Q. Zhao, Y.-S. Cheung, C.-X. Liao, C. Y. Ng, W.-K. Li, and S.-W. Chiu, J. Chem. Phys. 104, $130(1996)$. 
27. H.-Q. Zhao, Y.-S. Cheung D. P. Heck, C. Y. Ng, T. Tetzlaff, and W. S. Jenks, J. Chem. Phys. 106, 86 (1997).

28. C. Y. Ng, Adv. Photochem. 22, 1 (1997).

29. T.K.Minton, G.M.Nathanson, and Y.T.Lee, J.Chem.Phys. 86,1991 (1987)

30. E. J. Hintsa, X.Zhao, and Y.T.Lee, J.Chem.Phys. 92,2280 (1990).

31. X. Zhao, Ph.D. Thesis, University of California, Berkeley,CA (1988).

32. M. J. Frisch et al., GAUSSIAN 94 (Gaussian, Pittsburgh, PA, 1994).

33. S.-W. Chiu, W.-K. Li, W.-B. Tzeng, and C. Y. Ng, J. Chem. Phys. 97,6557 (1992).

34. A. Nicolades and L. Radom, Mol. Phys. 88, 759 (1996).

35. L. A. Curtiss, K. Raghavachari, P. C. Redfern, and J. A. Pople, J. Chem. Phys. 106, 1063 (1997).

36. G. E. Davico, V. M. Bierbaum, C. H. DePuy, G. B. Ellison, and R. R. Squires, J. Am. Chem. Soc. 117, 2590 (1995).

37. M. N. Glukhovtsev and S. Laiter, Theor. Chim. Acta 92, 32 (1995).

38. K. Raghavachar, B. B. Stefanov, L. A. Curtiss, J. Chem. Phys. 106, 6764 (1997).

39. The portion of the true $P\left(E_{c . m}\right)$ at $E_{c . m}<10.5 \mathrm{kcal} / \mathrm{mol}$ for process (2) is higher than that shown by the approximated $P\left(E_{c, m}\right)$. Thus, the true $P\left(E_{c, m}\right)$ is expected to peak at a $E_{c, m}$ lower than $10.5 \mathrm{kcal} / \mathrm{mol}$.

40. R. N. Zare, Mol. Photochem. 4, 1(1972)

41. J. G. Frey and P. Felder, Mol. Phys. 75,1419(1992) 


\title{
A 193 NM LASER PHOTOFRAGMENTATION TIME-OF-FLIGHT MASS SPECTROMETRIC STUDY OF DIMETHYLSULFOXIDE
}

\author{
A paper accepted by Journal of Chemical Physics
}

\author{
H.-Q. Zhao, Y.-S. Cheung, D. P. Heck, and C. Y. Ng
}

\begin{abstract}
The photodissociation of dimethylsulfoxide $\left[\left(\mathrm{CH}_{3}\right)_{2} \mathrm{SO}\right]$ at $193.3 \mathrm{~nm}$ has been investigated using the molecular beam time-of-flight (TOF) mass spectrometric technique. In addition to $\mathrm{CH}_{3}$ and $\mathrm{SO}, \mathrm{CH}_{3} \mathrm{SO}$ is also observed as a stable primary product, indicating that $\mathrm{CH}_{3} \mathrm{SO}+\mathrm{CH}_{3}$ is an important product channel for the $193.3 \mathrm{~nm}$ photodissociation of $\left(\mathrm{CH}_{3}\right)_{2} \mathrm{SO}$. The analysis of the TOF data provides evidence that $\mathrm{SO}$ is formed via a stepwise mechanism: $\left(\mathrm{CH}_{3}\right)_{2} \mathrm{SO}+\mathrm{hv}(193.3 \mathrm{~nm}) \rightarrow \mathrm{CH}_{3} \mathrm{SO}+\mathrm{CH}_{3} \rightarrow 2 \mathrm{CH}_{3}+\mathrm{SO}$. The analysis also indicates that $\approx 53 \%$ of the primary $\mathrm{CH}_{3} \mathrm{SO}$ radicals undergo further dissociation to produce $\mathrm{CH}_{3}+\mathrm{SO}$, yielding a quantum yield of $\approx 1.53$ for $\mathrm{CH}_{3}$. Within the sensitivity of our experiment, the product channel of $\mathrm{CH}_{3} \mathrm{SCH}_{3}+\mathrm{O}$ is not found. The angular distribution for the formation of $\mathrm{CH}_{3} \mathrm{SO}+\mathrm{CH}_{3}$ is found to be isotropic, an observation consistent with a predissociation mechanism, in which the dissociation of photoexcited $\left(\mathrm{CH}_{3}\right)_{2} \mathrm{SO}$ is slow compared to its rotational period. The energetics for selected dissociation reactions of $\left(\mathrm{CH}_{3}\right)_{2} \mathrm{SO}$ have also been investigated by $a b$ initio calculations at the G2(MP2) level of theory. The experimental dissociation energy at $0 \mathrm{~K}(53 \pm 2 \mathrm{kcal} / \mathrm{mol})$ for the $\mathrm{CH}_{3}-\mathrm{SOCH}_{3}$ bond obtained here is in excellent agreement with the theoretical prediction of $52.6 \mathrm{kcal} / \mathrm{mol}$.
\end{abstract}




\section{Introduction}

Photodissociation of polyatomic molecules generally involves more than one product channel, resulting from the multi-dimensional nature of the excited potential energy surfaces and the efficient energy redistribution between the internal degrees of motion of the excited precursor molecules. Because of the accessibility of multi-channel dissociation pathways, the identification of nascent products for such dissociation processes poses a great challenge to experimentalists. ${ }^{1}$ In the case when the final products are known, such as in the $193.3 \mathrm{~nm}$ photodissociation of acetone $\left[\left(\mathrm{CH}_{3}\right)_{2} \mathrm{CO}\right]$, the question of whether the products $\mathrm{CH}_{3}+\mathrm{CO}+$ $\mathrm{CH}_{3}$ are formed sequentially or concertedly has only been answered recently. ${ }^{3-5}$ This photodissociation reaction involves two equivalent $\mathrm{C}-\mathrm{C}$ bonds, both of which can be broken at $193.3 \mathrm{~nm}$. By measurements of the fragment kinetic energy distributions, the laser photofragmentation time-of-flight (TOF) study of North et al. ${ }^{4}$ has provided strong evidence that the $193.3 \mathrm{~nm}$ photodissociation of acetone proceeds via a stepwise mechanism. The stepwise mechanism is also found in the most recent ultrafast photofragmentation study of Kim et al., which examined the bond breaking process in real time. ${ }^{5}$ Despite the beauty of a concerted symmetric mechanism, the phase space associated with excited surfaces which leads to such a photodissociation process may not be high.

Dimethylsulfoxide $\left[\left(\mathrm{CH}_{3}\right)_{2} \mathrm{SO}\right]$ is a sulfur analog of acetone $\left[\left(\mathrm{CH}_{3}\right)_{2} \mathrm{CO}\right]$. Being the simplest sulfoxide, the photochemistry of $\left(\mathrm{CH}_{3}\right)_{2} \mathrm{SO}$ represents a model system for the understanding of sulfoxide photochemistry. In previous photochemical studies of $\left(\mathrm{CH}_{3}\right)_{2} \mathrm{SO}$ 
at $\mathrm{hv}=253.7 \mathrm{~nm}$ in solution, evidence is found indicating that the primary step is a C-S bond breaking process. ${ }^{6-9}$

$$
\left(\mathrm{CH}_{3}\right)_{2} \mathrm{SO}+\mathrm{hv} \rightarrow \mathrm{CH}_{3} \mathrm{SO}+\mathrm{CH}_{3}
$$

Secondary reactions involving $\mathrm{CH}_{3} \mathrm{SO}, \mathrm{CH}_{3}$, and $\left(\mathrm{CH}_{3}\right)_{2} \mathrm{SO}$ are ascribed to the formation of a series of sulfur-containing compounds, such as dimethylsulfide $\left(\mathrm{CH}_{3} \mathrm{SCH}_{3}\right){ }^{7}$ Since the production of $2 \mathrm{CH}_{3}+\mathrm{SO}$ from $\left(\mathrm{CH}_{3}\right)_{2} \mathrm{SO}$ requires $104 \mathrm{kcal} / \mathrm{mol}$ at $0 \mathrm{~K}$, ${ }^{6}$ the energy of 112 $\mathrm{kcal} / \mathrm{mol}$ corresponding to a $253.7 \mathrm{~nm}$ photon is adequate for breaking the two equivalent $\mathrm{C}$ $\mathrm{S}$ bonds in $\left(\mathrm{CH}_{3}\right)_{2} \mathrm{SO}$.

Absorption at $193.3 \mathrm{~nm}$ is assumed to be due to a $\mathrm{p} \rightarrow \mathrm{p}^{*}$ transition in the S-O group. ${ }^{7-9}$ Since a $193.3 \mathrm{~nm}$ photon corresponds to $147.9 \mathrm{kcal} / \mathrm{mol}$, which is well above the energy required to break the two $\mathrm{C}-\mathrm{S}$ bonds in $\left(\mathrm{CH}_{3}\right)_{2} \mathrm{SO}$, the formation of $2 \mathrm{CH}_{3}+\mathrm{SO}$ may be of considerable importance. This expectation is confirmed by recent photodissociation studies of $\left(\mathrm{CH}_{3}\right)_{2} \mathrm{SO}$ in the gas phase, ${ }^{10,11}$ in which were detected both $\mathrm{CH}_{3}$ and $\mathrm{SO}$ as the primary products. The rovibrational energy distributions for $\mathrm{CH}_{3}$ and $\mathrm{SO}$ in their ground states have also been measured using the resonance enhanced multiphoton ionization and laser induced fluorescence (LIF) techniques, respectively. ${ }^{10,11}$ On the basis of this information, together with the unity quantum yield measured for $\mathrm{SO}$, Chen et al. favor the concerted three-body fragmentation mechanism as the sole photodissociation pathway. ${ }^{11}$ 
In accordance with the known photochemistry of $\left(\mathrm{CH}_{3}\right)_{2} \mathrm{CO}$ at $193.3 \mathrm{~nm},{ }^{4,5}$ it is logical to suggest that the formation of $\mathrm{SO}$ and $\mathrm{CH}_{3}$ from $\left(\mathrm{CH}_{3}\right)_{2} \mathrm{SO}$ at $193.3 \mathrm{~nm}$ results from a stepwise mechanism, i.e., internally excited $\mathrm{CH}_{3} \mathrm{SO}$ radicals initially formed by process (1) undergo spontaneously dissociation according to process (2).

$$
\mathrm{CH}_{3} \mathrm{SO} \rightarrow \mathrm{CH}_{3}+\mathrm{SO}
$$

If this sequential mechanism is a realistic pathway for the production of SO, finite concentration of $\mathrm{CH}_{3} \mathrm{SO}$ initially formed by process (1) at $193.3 \mathrm{~nm}$ may be stable. However, the direct identification of primary $\mathrm{CH}_{3} \mathrm{SO}$ radicals formed in such a process has not been made previously.

We have undertaken a $193.3 \mathrm{~nm}$ laser photofragmentation TOF mass spectrometric study of $\left(\mathrm{CH}_{3}\right)_{2} \mathrm{SO}$. In addition to identifying $\mathrm{CH}_{3}, \mathrm{SO}$, and $\mathrm{CH}_{3} \mathrm{SO}$ as the primary photoproducts, we have also obtained the energy release spectra for these radicals. The analysis of the experimental results supports that processes (1) and (2) are the dominant pathways in the $193.3 \mathrm{~nm}$ photodissociation of $\left(\mathrm{CH}_{3}\right)_{2} \mathrm{SO}$. Cleavage of the $\mathrm{S}-\mathrm{O}$ bond in $\left(\mathrm{CH}_{3}\right)_{2} \mathrm{SO}$ to yield $\mathrm{CH}_{3} \mathrm{SCH}_{3}$ and $\mathrm{O}$ atom requires $85.3 \mathrm{kcal} / \mathrm{mol}^{6}$

$$
\left(\mathrm{CH}_{3}\right)_{2} \mathrm{SO}+\mathrm{h} v \rightarrow \mathrm{CH}_{3} \mathrm{SCH}_{3}+\mathrm{O}\left({ }^{3} \mathrm{P}\right)
$$

Since process (3) is exothermic by $62.7 \mathrm{kcal} / \mathrm{mol}$ for $\mathrm{hv}=193.3 \mathrm{~nm},{ }^{6}$ we have also search for the formation of $\mathrm{CH}_{3} \mathrm{SCH}_{3}$ and $\mathrm{O}$ atom. 
To our knowledge, the heat of formation at $0 \mathrm{~K}\left[\mathrm{D}_{\mathrm{f}} \mathrm{H}_{0}^{\circ}\right]$ for $\mathrm{CH}_{3} \mathrm{SO}$ is not well known. ${ }^{6,12}$ In order to interpret the TOF data obtained in this study, we have also conducted an $a b$ initio quantum chemical study on selected dissociation processes of $\left(\mathrm{CH}_{3}\right)_{2} \mathrm{SO}$, which involves the energetic and structural calculations of $\left(\mathrm{CH}_{3}\right)_{2} \mathrm{SO}, \mathrm{CH}_{3} \mathrm{SCH}_{3}, \mathrm{CH}_{3} \mathrm{SO}$, and $\mathrm{CH}_{2} \mathrm{SO}$ at the G2(MP2) level ${ }^{13,14}$ of theory.

\section{Experimental and Theoretical Methods}

\section{A. Experiment}

The rotatable beam source laser photofragmentation TOF apparatus used in this study has been described in detail. ${ }^{15}$ The apparatus consists of three main components: an ArF excimer laser, a photodissociation chamber in which a rotatable supersonic molecular beam intersects with the excimer laser beam, and a linearly movable ultrahigh vacuum electron ionization quadrupole mass spectrometer (QMS).

In this experiment, a pulsed beam of $\left(\mathrm{CH}_{3}\right)_{2} \mathrm{SO}$ ( 3 or $3.8 \%$ seeded in $\mathrm{He}$ ) is produced by supersonic expansion through a commercial pulsed valve (General Valve, No. 9) with a nozzle diameter of $0.5 \mathrm{~mm}$ at $323 \mathrm{~K}$ and a total stagnation pressure of $\approx 1535 \mathrm{Torr}$. The pulsed valve is operated at $40 \mathrm{~Hz}$. The seeded $\left(\mathrm{CH}_{3}\right)_{2} \mathrm{SO}$ beam has an angular divergence of $3^{\circ}$ which is defined by the opening of the conical skimmer and the circular aperture as it passes through the differential chamber into the photodissociation chamber. The $3^{\circ}$ angular spread of the beam corresponds to a beam width of $3 \mathrm{~mm}$ at the photodissociation region. During the experiment, the photodissociation chamber is maintained at a pressure of $1 \times 10^{-8}$ Torr. 
The excimer laser (Questek model 2460) was operated at 35-50 mJ. The laser beam enters the photodissociation chamber through a $\mathrm{MgF}_{2}$ focusing lens and is perpendicular to the seeded $\left(\mathrm{CH}_{3}\right)_{2} \mathrm{SO}$ beam and the central axis of the QMS. The spot size of the excimer laser beam is estimated to be $\approx 5 \mathrm{~mm}^{2}$ at the photodissociation region.

All TOF spectra are taken at a flight path of $65.5 \mathrm{~cm}$ which is defined by the distance between the photodissociation region and the ionizer. The emission current of the ionizer is about $1.25 \mathrm{~mA}$ and the ionization electron energy is about $75 \mathrm{eV}$.

The TOF spectra presented here were recorded on a multichannel scaler (Stanford Research model SRT430) with a channel width of $1.28 \mu \mathrm{s}$. The ion drift times through the QMS were determined to be $4.114 \mathrm{~m}^{1 / 2}$, where $\mathrm{m}$ is the ion mass. The actual flight times of photofragments were corrected for the corresponding ion drift times. The velocity distribution of the parent $\left(\mathrm{CH}_{3}\right)_{2} \mathrm{SO}$ beam was determined by taking laser hole burning spectra of $\left(\mathrm{CH}_{3}\right)_{2} \mathrm{SO}$ at $\theta_{\mathrm{lab}}=0^{\circ}$, where $\theta_{\mathrm{lab}}$ is the angle between the $\left(\mathrm{CH}_{3}\right)_{2} \mathrm{SO}$ beam and the detector axis. The measured speed profile of species was then fitted to an assumed functional form, ${ }^{15,16} \mathrm{f}(\mathrm{v}) \sim \mathrm{v}^{2} \exp \left[-\left(\mathrm{v}-\mathrm{v}_{\mathrm{o}}\right)^{2} / \alpha^{2}\right]$, where $\mathrm{v}_{\mathrm{o}}$ is the most probable speed and $\alpha$ is a measure of the width of the speed profile. In this experiment, the values of $v_{0}$ and $\alpha$ for a beam of $3 \%\left(\mathrm{CH}_{3}\right)_{2} \mathrm{SO}$ seeded in $\mathrm{He}$ are determined to be $1.64 \times 10^{5}$ and $5.5 \times 10^{3} \mathrm{~cm} / \mathrm{s}$, respectively. For a beam of $3.8 \%\left(\mathrm{CH}_{3}\right)_{2} \mathrm{SO}$ seeded in $\mathrm{He}$, the respective $\mathrm{v}_{\mathrm{o}}$ and $\alpha$ values are $1.56 \times 10^{5}$ and $5.2 \times 10^{3} \mathrm{~cm} / \mathrm{s}$

The analysis of the TOF data was performed by a forward simulation method. ${ }^{17,18}$ Briefly, the procedure began with a trial center-of-mass (c.m.) kinetic energy $\left(E_{c . m .}\right)$ 
distribution, i.e., $P\left(E_{c . m}\right)$, which was transformed to a TOF spectrum for comparison with the experimental TOF spectrum. The $P\left(E_{c . m}\right)$ distribution was adjusted until satisfactory agreement between the experimental and calculated TOF data was obtained. For the determination of the kinetic energy threshold for process $(1)$, the $P\left(E_{c . m .}\right)$ distribution near the $E_{c . m}$ onset was obtained by direct transformation of the TOF data.

In angular distribution measurements, the laser light was polarized by a stack of ten quartz plates set at the Brewster angle. The electric vector $\mathbf{E}$ of the polarized laser beam was set perpendicular to the detector and then rotated into the desired direction with a halfwave retarder. The laser energy was measured by a pyroelectric detector, and was kept at $10 \mathrm{~mJ} /$ pulse. The $\theta_{\mathrm{lab}}$ value was set at $15^{\circ}$ or $30^{\circ}$ with respect to the detector axis. In order to determine the angular distribution for process (1), the TOF spectra for $\mathrm{CH}_{3} \mathrm{SO}$ and $\mathrm{SO}$ was recorded as a function of $\varepsilon$ with each spectrum accumulated for a fixed number of laser shots, where $\varepsilon$ is the angle between $\mathbf{E}$ and the direction of the molecular beam. In this experiment, the detector axis, the molecular beam axis, and $\mathbf{E}$ are in the same plane, which is perpendicular to the laser propagation direction.

\section{B. $A b$ initio calculations}

The Gaussian-2 (G2) ab initio theoretical procedure has been described in detail by Curtiss et al. ${ }^{13}$ Briefly, at the G2 level of theory, molecular structures are optimized with the Hartree-Fock (HF) approach and the second-order Møller-Plesset perturbation theory (MP2) with all electrons included using the 6-31G(d) basis set [i.e., at the HF/6-31G(d) and MP2(full)/6-31G(d) levels]. Harmonic vibrational frequencies are calculated at the HF/6- 
$31 G(d)$ geometries for stationary point characterization. All subsequent single-point calculations at higher levels involved are based on the MP2/6-31G(d) optimized structures. Approximations of QCISD(T)/6-311+G(3df,2p) energies are obtained with frozen-core single-point calculations at the QCISD(T)/6-311G(d,p), MP4/6-311G(d,p), MP4/6311+G(d,p), MP4/6-311G(2df,p), and MP2/6-311+G(3df,2p) levels. A small semiempirical correction is applied to account for high level correlation effects to obtain the total electronic energy $\left(E_{e}\right)$. The HF/6-31G(d) harmonic vibrational frequencies, scaled by 0.8929 , are used for zero-point vibrational energy (ZPVE) correction. The total energy at $0 \mathrm{~K}\left(\mathrm{E}_{0}\right)$ is equal to $E_{e}+Z P V E$.

The G2(MP2) theory ${ }^{14}$ is a variation of the G2 procedure in which the single-point energies are only calculated at the $\mathrm{QCISD}(\mathrm{T}) / 6-311 \mathrm{G}(\mathrm{d}, \mathrm{p})$ and MP2/6-311+G(3df,2p) levels. In this study, the $\mathrm{E}_{0}[\mathrm{G} 2(\mathrm{MP} 2)]$ values for $\left(\mathrm{CH}_{3}\right)_{2} \mathrm{SO}, \mathrm{CH}_{3} \mathrm{SCH}_{3}, \mathrm{CH}_{3} \mathrm{SO}, \mathrm{CH}_{2} \mathrm{SO}$, $\mathrm{CH}_{3}$ and SO were calculated using the Gaussian-94 for Windows package. ${ }^{19}$ All calculations were performed on a Pentium (166 MHz) PC. In the following sections, the structural parameters refer to those from calculations obtained at the MP2(full)/6-31G(d) level unless otherwise specified.

The optimized geometries of $\left(\mathrm{CH}_{3}\right)_{2} \mathrm{SO}\left(\mathrm{C}_{\mathrm{s}}\right), \mathrm{CH}_{3} \mathrm{SCH}_{3}\left(\mathrm{C}_{2 \mathrm{v}}\right), \mathrm{CH}_{3} \mathrm{SO}\left(\mathrm{C}_{\mathrm{s}}\right)$, and planar$\mathrm{CH}_{2} \mathrm{SO}\left(\mathrm{C}_{\mathrm{s}}\right)$ in their ground states are depicted in Figs. 1(a), 1(b), 1(c), and 1(d). Calculations show that $\mathrm{CH}_{2} \mathrm{SO}$ has a higher energy cyclic isomer, the structure of which is shown in Fig. 1(e). The structural parameters of these species are summarized in Table I. The $E_{0}[G 2(M P 2)], D_{f} H_{0}^{\circ}[G 2(M P 2)]$, and the experimental $D_{f} H_{0}^{\circ}\left[D_{f} H^{\circ}\left(\right.\right.$ expt)] values ${ }^{6}$ for 


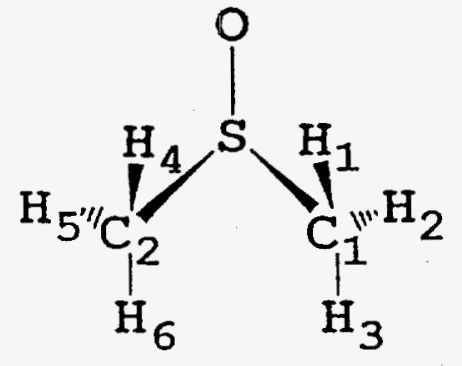

(a) $\left(\mathrm{CH}_{3}\right)_{2} \mathrm{SO}\left(C_{\mathrm{s}}\right)$<smiles>CSC(C)C</smiles>

(b) $\left(\mathrm{CH}_{3}\right)_{2} \mathrm{~S}\left(\mathrm{C}_{2 v}\right)$<smiles>[H][Z1]([H])([H])[S-]O</smiles>

(c) $\mathrm{CH}_{3} \mathrm{SO}\left(C_{s}\right)$<smiles>CSO</smiles>

(d) planar- $\mathrm{CH}_{2} \mathrm{SO}\left(C_{s}\right)$<smiles>C1OS1</smiles>

(e) cyclic- $\mathrm{CH}_{2} \mathrm{SO}\left(C_{s}\right)$

Figure 1. The structures of (a) $\left(\mathrm{CH}_{3}\right)_{2} \mathrm{SO}\left(\mathrm{C}_{3}\right)$, (b) $\mathrm{CH}_{3} \mathrm{SCH}_{3}\left(\mathrm{C}_{2 v}\right)$, (c) $\mathrm{CH}_{3} \mathrm{SO}\left(\mathrm{C}_{3}\right)$, (d) planar$\mathrm{CH}_{2} \mathrm{SO}\left(\mathrm{C}_{\mathrm{s}}\right)$, and (e) cyclic- $\mathrm{CH}_{2} \mathrm{SO}\left(\mathrm{C}_{3}\right)$ optimizing at the MP2/6-31G(d) level. 
Table I. Structural parameters for $\left(\mathrm{CH}_{3}\right)_{2} \mathrm{SO}, \mathrm{CH}_{3} \mathrm{SCH}_{3}, \mathrm{CH}_{3} \mathrm{SO}$ and $\mathrm{CH}_{2} \mathrm{SO}$ calculated at the MP2(full)/6-31G(d) level. ${ }^{2}$

\begin{tabular}{cccccc}
\hline Parameters ${ }^{\mathrm{b}}$ & $\left(\mathrm{CH}_{3}\right)_{2} \mathrm{SO}$ & $\mathrm{CH}_{3} \mathrm{SCH}_{3}$ & $\mathrm{CH}_{3} \mathrm{SO}$ & planar- $\mathrm{CH}_{2} \mathrm{SO}$ & cyclic- $\mathrm{CH}_{2} \mathrm{SO}$ \\
\hline$r(\mathrm{~S}-\mathrm{O})$ & 1.510 & -- & 1.488 & 1.493 & 1.777 \\
$r[\mathrm{C}(1)-\mathrm{S}]$ & 1.806 & 1.804 & 1.801 & 1.625 & 1.779 \\
$r[\mathrm{C}(1)-\mathrm{H}(1)]$ & 1.093 & 1.091 & 1.092 & 1.085 & 1.089 \\
$r[\mathrm{C}(1)-\mathrm{H}(2)]$ & 1.091 & 1.093 & 1.092 & 1.085 & 1.089 \\
$r[\mathrm{C}(1)-\mathrm{H}(3)]$ & 1.093 & 1.093 & 1.092 & -- & - \\
$\angle[\mathrm{OSC}(1)]$ & 107.4 & - & 107.0 & 115.4 & 46.5 \\
$\angle[\mathrm{C}(1) \mathrm{SC}(2)]$ & 95.8 & 98.5 & - & - & - \\
$\angle[\mathrm{SC}(1) \mathrm{H}(1)]$ & 109.3 & 107.7 & 109.4 & 122.7 & 116.8 \\
$\angle[\mathrm{SC}(1) \mathrm{H}(2)]$ & 107.4 & 111.3 & 109.0 & 116.1 & 116.8 \\
$\angle[\mathrm{SC}(1) \mathrm{H}(3)]$ & 110.3 & 111.3 & 109.0 & - & - \\
$\angle[\mathrm{C}(2) \mathrm{SC}(1) \mathrm{H}(1)]$ & -59.4 & 180.0 & - & - & - \\
$\angle[\mathrm{C}(2) \mathrm{SC}(1) \mathrm{H}(2)]$ & -177.8 & 61.1 & - & - & - \\
$\angle[\mathrm{C}(2) \mathrm{SC}(1) \mathrm{H}(3)]$ & 62.7 & -61.1 & - & - & - \\
$\angle[\mathrm{OSC}(1) \mathrm{H}(1)]$ & 0.8 & - & 180.0 & 0.0 & -107.7 \\
$\angle[\mathrm{OSC}(1) \mathrm{H}(2)]$ & -67.6 & - & -59.5 & 180.0 & - \\
$\angle[\mathrm{OSC}(1) \mathrm{H}(3)]$ & 172.9 & - & 59.5 & - & - \\
\hline \hline
\end{tabular}

a). Bond lengths $(r)$ are in $\AA$ and bond angles $(\angle)$ are in degree.

b). See Fig. 1 for the labels of the S, C, O, and $\mathrm{H}$ atoms. 
Table II. $\mathrm{E}_{0}[\mathrm{G} 2(\mathrm{MP} 2)], \mathrm{D}_{\mathrm{f}} \mathrm{H}_{0}^{\circ}$ [G2(MP2)], and $\mathrm{D}_{\mathrm{f}} \mathrm{H}^{\circ}{ }_{0}$ (expt) values for $\left(\mathrm{CH}_{3}\right)_{2} \mathrm{SO}$, $\mathrm{CH}_{3} \mathrm{SCH}_{3}, \mathrm{CH}_{3} \mathrm{SO}, \mathrm{CH}_{3}, \mathrm{SO}$, and $\mathrm{CH}_{2} \mathrm{SO}$ isomers.

\begin{tabular}{|c|c|c|c|}
\hline Species & $\begin{array}{l}\mathrm{E}_{0}[\mathrm{G} 2(\mathrm{MP} 2)] \\
\text { (hartree) }\end{array}$ & $\begin{array}{l}\mathrm{D}_{\mathrm{f}} \mathrm{H}_{0}^{\circ}[\mathrm{G} 2(\mathrm{MP} 2)]^{2} \\
(\mathrm{kcal} / \mathrm{mol})\end{array}$ & $\begin{array}{l}\mathrm{D}_{\mathrm{f}} \mathrm{H}_{0}^{\circ}(\operatorname{expt})^{\mathrm{b}} \\
(\mathrm{kcal} / \mathrm{mol})\end{array}$ \\
\hline$\left(\mathrm{CH}_{3}\right)_{2} \mathrm{SO}$ & -552.47881 & -32.2 & -31.4 \\
\hline $\mathrm{CH}_{3} \mathrm{SCH}_{3}$ & -477.36393 & -5.7 & -5.1 \\
\hline $\mathrm{CH}_{3} \mathrm{SO}$ & -512.65102 & -15.8 & $-14.8 \pm 2^{\mathrm{c}}$ \\
\hline planar $-\mathrm{CH}_{2} \mathrm{SO}$ & -512.05506 & -7.2 & --- \\
\hline cyclic- $\mathrm{CH}_{2} \mathrm{SO}$ & -512.03032 & 8.3 & -- \\
\hline $\mathrm{CH}_{3}$ & -39.74390 & 36.2 & 35.6 \\
\hline SO & -472.81931 & 3.1 & $1.2 \pm 0.3$ \\
\hline \multicolumn{4}{|c|}{$\begin{array}{l}\text { a). Calculated using the } \mathrm{D}_{\mathrm{H}} \mathrm{H}_{0}^{\circ}(\mathrm{expt}) \text { values of } \mathrm{C}(170.0 \mathrm{kcal} / \mathrm{mol}), \mathrm{O}\left({ }^{3} \mathrm{P}\right)(59.0 \mathrm{kcal} / \mathrm{mol}), \mathrm{S}(65.6 \\
\mathrm{kcal} / \mathrm{mol}) \text {, and } \mathrm{H}(51.63 \mathrm{kcal} / \mathrm{mol}) \text { from Ref. } 9 ; \mathrm{E}_{0}[\mathrm{G} 2(\mathrm{MP})] \text { values of } \mathrm{C}(-37.76390 \\
\text { hartree), } \mathrm{O}\left({ }^{3} \mathrm{P}\right)(-74.97868 \mathrm{hartree}), \mathrm{S}(-397.64699 \text { hartree}) \text {, and } \mathrm{H}(-0.50000 \text { hartree }) \text {. See } \\
\text { Ref. } 20 \text {. } \\
\text { b). Values are from Ref. } 9 \text {. } \\
\text { c). This work. }\end{array}$} \\
\hline
\end{tabular}


these species, $\mathrm{CH}_{3}$, and $\mathrm{SO}$ are listed in Table II. The $\mathrm{D}_{\mathrm{f}} \mathrm{H}_{0}^{\circ}[\mathrm{G} 2(\mathrm{MP} 2)]$ values are obtained using the $\mathrm{D}_{\mathrm{f}} \mathrm{H}^{\circ}{ }_{0}(\mathrm{expt})$ values of $\mathrm{H}(51.6 \mathrm{kcal} / \mathrm{mol}), \mathrm{C}(170 \mathrm{kcal} / \mathrm{mol}), \mathrm{O}(59.0 \mathrm{kcal} / \mathrm{mol})$, and $S(65.6 \mathrm{kcal} / \mathrm{mol}), E_{0}[\mathrm{G} 2(M P 2)]$ values of the molecular species given in Table II, and $\mathrm{E}_{0}[\mathrm{G} 2(\mathrm{MP} 2)]$ values of $\mathrm{H}(-0.50000$ hartree $), \mathrm{C}(-37.76390$ hartree $), \mathrm{O}\left({ }^{3} \mathrm{P}\right)(-74.97868$ hartree), and $\mathrm{S}\left(-397.64699\right.$ hartree) ${ }^{20}$ The known $\mathrm{D}_{\mathrm{f}} \mathrm{H}_{0}^{\circ}$ (expt) values for $\left(\mathrm{CH}_{3}\right)_{2} \mathrm{SO}, \mathrm{CH}_{3}$, and $\mathrm{SO}$ are in good agreement with the corresponding $\mathrm{D}_{\mathrm{f}} \mathrm{H}^{\circ}{ }_{0}[\mathrm{G} 2(\mathrm{MP} 2)]$ predictions. Despite the similarity in atom connectivities for $\left(\mathrm{CH}_{3}\right)_{2} \mathrm{CO}$ and $\left(\mathrm{CH}_{3}\right)_{2} \mathrm{SO}$, the bonding structures for these two molecules are quite different. In the case of $\left(\mathrm{CH}_{3}\right)_{2} \mathrm{CO}$, the bonding around $\mathrm{C}$ is best described by $s p^{2}$ hybridization with the four heavy atoms lie on the same plane. The bonding between $\mathrm{C}$ and $\mathrm{O}$ is characterized by a full double bond. The angle between the two O-S-C planes in $\left(\mathrm{CH}_{3}\right)_{2} \mathrm{SO}$ is $102.0^{\circ}$, indicating that the bonding around the $\mathrm{S}$ atom can be considered as $s p^{3}$ hybridization. To fulfill the octet shell rule for the $\mathrm{S}$ atom, the most stable structure for dimethylsulfoxide has the zwitterion form $\left(\mathrm{CH}_{3}\right)_{2} \mathrm{~S}^{+}-\mathrm{O}^{-}$. Here, the $\mathrm{S}$ atom is surrounded by three s-bonds and one lone pair. The stability of the latter structure is achieved due to the greater electronegativity of the $\mathrm{O}$ atom compared to that of the $\mathrm{S}$ atom. The zwitterion structure is consistent with a significant single bond character for the S-O bond. Finite $p$-bonding between $\mathrm{S}$ and $\mathrm{O}$ atoms can be rationalized by the hypervalent nature of the $\mathrm{S}$ atom, a concept of which invokes the bonding participation of the sulfur $d$ orbitals. Including the $p$-bond, the $\mathrm{S}$ atom is surrounded by ten electrons with the structure $\left(\mathrm{CH}_{3}\right)_{2} \mathrm{~S}=\mathrm{O}$. However, the high energy and diffuse characters of the sulfur $d$ - orbitals make them inefficient for bonding. According to this bonding picture, the S-O bond energy in 
$\left(\mathrm{CH}_{3}\right)_{2} \mathrm{SO}$ is expected to be significantly lower than that of a double bond. As pointed out above, the energy of a $193.3 \mathrm{~nm}$ photon is more than sufficient to break the C-S bond or the S-O bond yielding $\mathrm{CH}_{3} \mathrm{SO}+\mathrm{CH}_{3}$ or $\mathrm{CH}_{3} \mathrm{SCH}_{3}+\mathrm{O}$, respectively. The five highest occupied orbitals for a dialkylsulfoxide, such as $\left(\mathrm{CH}_{3}\right)_{2} \mathrm{SO}$, have been characterized as $n(\mathrm{~S}), p(\mathrm{SO})$, $s(\mathrm{SO}), s(\mathrm{CSC})$, and $n(\mathrm{O})$, where $n(\mathrm{~S})$ and $n(\mathrm{O})$ represent nonbonding orbital localized at the $\mathrm{S}$ and $\mathrm{O}$ atoms, respectively. ${ }^{21}$

As shown in Table $\mathrm{I}$, the structural parameters in $\mathrm{CH}_{3} \mathrm{SCH}_{3}$ and $\mathrm{CH}_{3} \mathrm{SO}$ are similar to the corresponding values in $\left(\mathrm{CH}_{3}\right)_{2} \mathrm{SO}$. The bonding picture used to describe the bonding between $\mathrm{S}$ and $\mathrm{O}$ in $\left(\mathrm{CH}_{3}\right)_{2} \mathrm{SO}$ is mostly applicable to that in $\mathrm{CH}_{3} \mathrm{SO}$ and planar- $\mathrm{CH}_{2} \mathrm{SO}$. The $\mathrm{CH}_{2} \mathrm{~S}^{+}-\mathrm{O}^{-}$structure allows $\mathrm{S}$ to fulfill the octet rule, whereas the hypervalent form, $\mathrm{CH}_{2}=\mathrm{S}=\mathrm{O}$, emphasizes a finite double bond character for the bonding between $\mathrm{S}$ and $\mathrm{O}$. The cyclic $-\mathrm{CH}_{2} \mathrm{SO}$ isomer is a typical molecule fulfilling the octet rule. Although a three-member ring is not a structure for favorable bonding interactions, it is interesting to note that the cyclic isomer is predicted to be less stable than the planar one by only $15.5 \mathrm{kcal} / \mathrm{mol}$ at the G2(MP2) level.

\section{Results and Discussion}

Table III compares the theoretical and experimental values for selected bond dissociation energies at $0 \mathrm{~K}\left(\mathrm{D}_{0}\right)$ for $\left(\mathrm{CH}_{3}\right)_{2} \mathrm{SO}$ and $\mathrm{CH}_{3} \mathrm{SO}$. The $\mathrm{D}_{0}[\mathrm{G} 2(\mathrm{MP} 2)]$ value for the first $\mathrm{C}-\mathrm{S}$ bond in $\left(\mathrm{CH}_{3}\right)_{2} \mathrm{SO}$ is $52.6 \mathrm{kcal} / \mathrm{mol}$. An experimental value identical to this prediction was cited [as unpublished results] in Ref. 7 for the C-S bond dissociation energy in $\left(\mathrm{CH}_{3}\right)_{2} \mathrm{SO}$. However, the temperature associated with this experimental value was not 
given. An estimate of $55 \pm 2 \mathrm{kcal} / \mathrm{mol}$ was given for the $\mathrm{CH}_{3}-\mathrm{SOCH}_{3}$ bond dissociation energy at $298 \mathrm{~K}$ by Benson. ${ }^{12}$

Using $52.6 \mathrm{kcal} / \mathrm{mol}$ for $\mathrm{D}_{0}\left(\mathrm{CH}_{3}-\mathrm{SOCH}_{3}\right)$, we have constructed the Newton diagram in Fig. 2 for process (1) at $\mathrm{hn}=193.3 \mathrm{~nm}$. As shown in the figure, $\mathrm{v}_{\mathrm{o}}=1.64 \times 10^{5} \mathrm{~cm} / \mathrm{s}, \mathrm{v}_{\mathrm{lab}}$ and $v_{c . m .}$ are the laboratory and c.m. velocities for the photofragments, $\theta_{\text {c.m. }}$ is the c.m. angle, defined by the angle between $v_{c . m .}$ and the detector axis. The circles defined by $v_{c . m}\left(\mathrm{CH}_{3}\right)$ and $v_{c . m .}\left(\mathrm{CH}_{3} \mathrm{SO}\right)$ represent the maximum $\mathrm{v}_{\text {c.m. }}$ 's for $\mathrm{CH}_{3}$ and $\mathrm{CH}_{3} \mathrm{SO}$. Also shown in Fig. 2 are $\gamma$ and $\varepsilon$, which are defined as the angles between the laser electric field $\mathbf{E}$ and $v_{c . m}$ and between $\mathbf{E}$ and the detector axis, respectively.

Throughout the discussion below, we refer to processes (1)-(3) as at $\mathrm{h} v=193.3 \mathrm{~nm}$. The TOF spectra for $\mathrm{CH}_{3} \mathrm{SO}, \mathrm{CH}_{2} \mathrm{SO}$, and $\mathrm{CH}_{2} \mathrm{~S}$ obtained at $\theta_{\mathrm{lab}}=15^{\circ}$ are depicted in Figs. 3(a), 3(b), and 3(c), respectively. Figures 4(a) and 4(b) show the respective TOF spectra for $\mathrm{CH}_{3}$ observed at $\theta_{\mathrm{lab}}=15^{\circ}$ and $30^{\circ}$. Shown in Figs. 5(a), 5(b), 5(c), and 5(d) are the TOF spectra for SO observed at $\theta_{\mathrm{lab}}=15^{\circ}, 30^{\circ}, 40^{\circ}$, and $45^{\circ}$, respectively.

The observation of $\mathrm{CH}_{3} \mathrm{SO}$ here unambiguously shows that process (1) is an important photo-dissociation channel. The goal of the data analysis is to derive the $E_{c . m . ~}$ distributions $\left[\mathrm{P}\left(\mathrm{E}_{\mathrm{c} . \mathrm{m}}\right)\right]$ for processes (1) as shown in Fig. 6, which fit all the TOF spectra of $\mathrm{CH}_{3} \mathrm{SO}, \mathrm{CH}_{3}$, and SO of Figs. 3-5. The detailed procedure involves tedious adjustments starting from a trial $\mathrm{P}\left(\mathrm{E}_{\mathrm{c} . \mathrm{m}}\right)$. The reasoning in arriving the $\mathrm{P}\left(\mathrm{E}_{\mathrm{c} . \mathrm{m}}\right)$ for process (1) is described below. The $\mathrm{P}\left(\mathrm{E}_{\text {c.m. }}\right)$ at $\mathrm{E}_{\mathrm{c} . \mathrm{m} .} \approx 6-50 \mathrm{kcal} / \mathrm{mol}$ shown by solid circles in Fig. 6 is obtained by fitting the TOF spectrum of $\mathrm{CH}_{3} \mathrm{SO}$. This can be viewed as a trial $\mathrm{P}\left(\mathrm{E}_{\mathrm{c} . \mathrm{m}}\right)$ for process (1). The $\mathrm{P}\left(\mathrm{E}_{\mathrm{c} . \mathrm{m}}\right)$ thus 
Table III. Theoretical and experimental values for selected bond dissociation energies at $0 \mathrm{~K}$ $\left(\mathrm{D}_{0}\right)$ for $\left(\mathrm{CH}_{3}\right)_{2} \mathrm{SO}$ and $\mathrm{CH}_{3} \mathrm{SO}$.

\begin{tabular}{lll}
\hline Reactions & $\begin{array}{l}\mathrm{D}_{0}[\mathrm{G} 2(\mathrm{MP} 2)]^{\mathrm{a}} \\
(\mathrm{kcal} / \mathrm{mol})\end{array}$ & $\begin{array}{l}\mathrm{D}_{0}(\mathrm{expt})^{\mathrm{b}} \\
(\mathrm{kcal} / \mathrm{mol})\end{array}$ \\
\hline$\left(\mathrm{CH}_{3}\right)_{2} \mathrm{SO} \rightarrow \mathrm{CH}_{3} \mathrm{SO}+\mathrm{CH}_{3}$ & 52.6 & $--^{\mathrm{c}}$ \\
$\left(\mathrm{CH}_{3}\right)_{2} \mathrm{SO} \rightarrow \mathrm{CH}_{3} \mathrm{SCH}_{3}+\mathrm{O}\left({ }^{3} \mathrm{P}\right)$ & 85.5 & 85.3 \\
$\left(\mathrm{CH}_{3}\right)_{2} \mathrm{SO} \rightarrow \mathrm{CH}_{3} \mathrm{SCH}_{3}+\mathrm{O}\left({ }^{\mathrm{l}} \mathrm{D}\right)$ & -- & $130.7^{\mathrm{d}}$ \\
$\left(\mathrm{CH}_{3}\right)_{2} \mathrm{SO} \rightarrow 2 \mathrm{CH}_{3}+\mathrm{SO}$ & 107.7 & 103.8 \\
$\mathrm{CH}_{3} \mathrm{SO} \rightarrow \mathrm{CH}_{3}+\mathrm{SO}$ & 55.1 & -- \\
$\mathrm{CH}_{3} \mathrm{SO} \rightarrow$ planar $-\mathrm{CH}_{2} \mathrm{SO}+\mathrm{H}$ & 60.2 & - \\
$\mathrm{CH}_{3} \mathrm{SO} \rightarrow$ cyclic-CH$-\mathrm{CH}_{2} \mathrm{SO}+\mathrm{H}$ & 75.7 & -- \\
\hline \hline
\end{tabular}

a). Calculated using the $\mathrm{E}_{0}$ values given in Table II.

b). Calculated using the $\mathrm{D}_{\mathrm{H}} \mathrm{H}_{0}^{\circ}$ (expt) values given in Table II.

c). A value of $52.6 \mathrm{kcal} / \mathrm{mol}$ for the $\mathrm{C}-\mathrm{S}$ bond dissociation energy in $\left(\mathrm{CH}_{3}\right)_{2} \mathrm{SO}$ was cited as unpublished results in Ref. 6 . However, the temperature associated with this value is unknown.

d). The excited $\mathrm{O}\left({ }^{1} \mathrm{D}\right)$ state is higher than the ground $\mathrm{O}\left({ }^{3} \mathrm{P}\right)$ state by $45.4 \mathrm{kcal} / \mathrm{mol}$ (Ref. 23). 


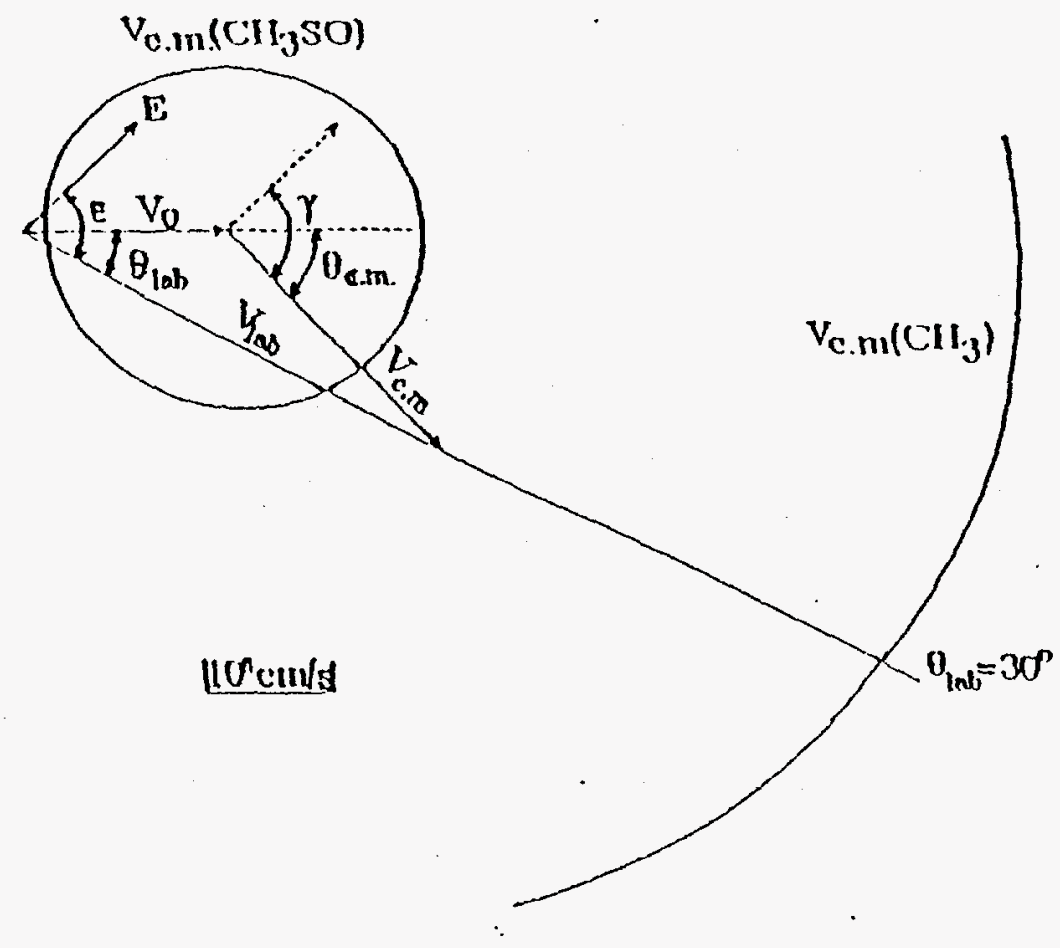

Figure 2. Kinematics for the formation of $\mathrm{CH}_{3} \mathrm{SO}+\mathrm{CH}_{3}$ by $193.3 \mathrm{~nm}$ photodissociation of $\left(\mathrm{CH}_{3}\right)_{2} \mathrm{SO} . \mathrm{v}_{\mathrm{o}}\left(=1.64 \times 10^{5} \mathrm{~cm} / \mathrm{s}\right)$ is the laboratory velocity for the $\left(\mathrm{CH}_{3}\right)_{2} \mathrm{SO}$ beam. $v_{c . m}\left(\mathrm{CH}_{3} \mathrm{SO}\right)$ and $\mathrm{v}_{\mathrm{c} . \mathrm{m}}\left(\mathrm{CH}_{3}\right)$ are the maximum c.m. velocities for $\mathrm{CH}_{3} \mathrm{SO}$ and $\mathrm{CH}_{3}$, respectively. The diagram shows the relationship $\gamma=\theta_{\text {c.m }}+\varepsilon-\theta_{\text {lab }}$ where $\gamma$ is the angle between the laser electric field $(\boldsymbol{E})$ and the $\mathrm{c} . \mathrm{m}$. velocity for the photofragment $\left(v_{c . m}\right), \theta_{c . m}$ is the angle between $v_{o}$ and $v_{c . m}, \varepsilon$ is the angle between $\mathbf{E}$ and the detector axis, and $\theta$ is the laboratory angle between $v_{0}$ and the detector axis. 


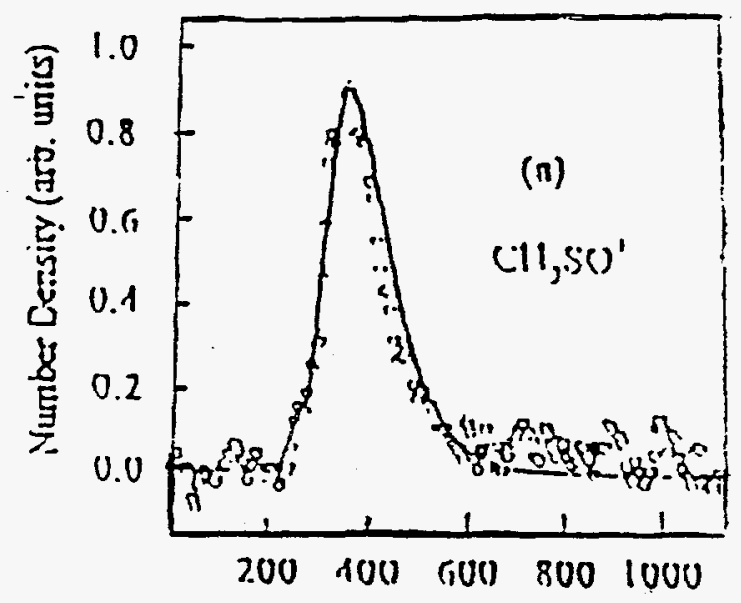

liLIGIIT TIMLE (1IS)

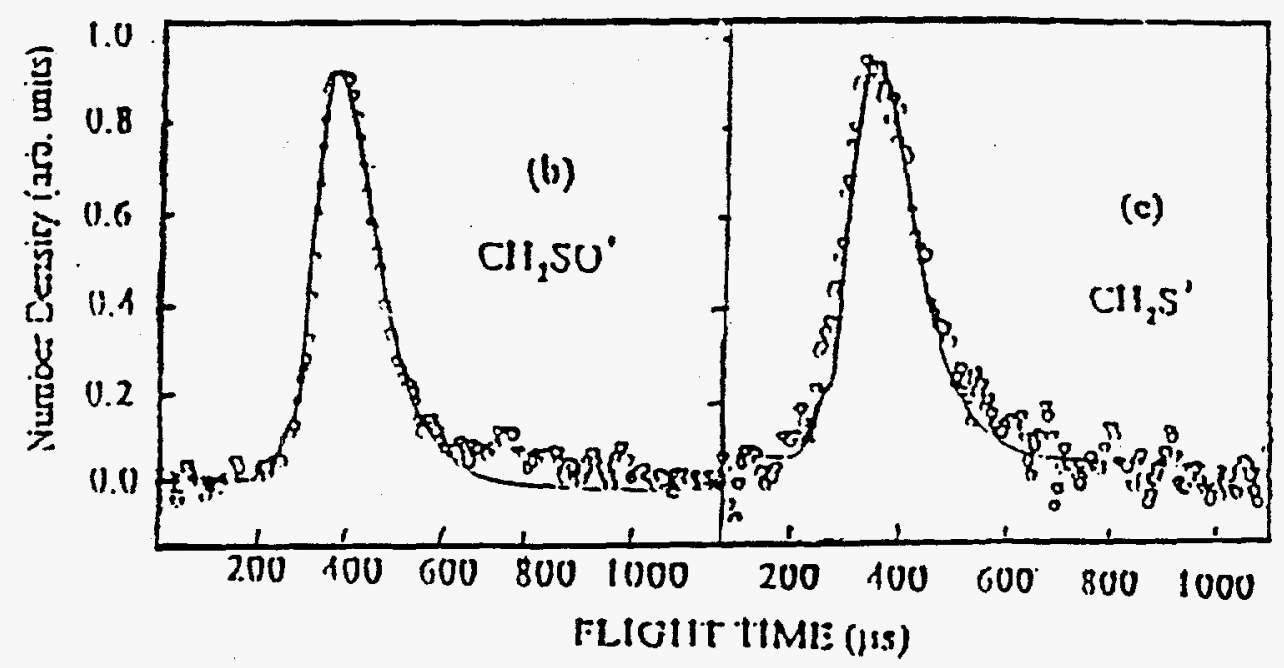

Figure 3. TOF spectra for (a) $\mathrm{CH}_{3} \mathrm{SO}$, (b) $\mathrm{CH}_{2} \mathrm{SO}$, (c) $\mathrm{CH}_{2} \mathrm{~S}$ obtained at $\mathrm{e}_{\mathrm{Lb}}=15^{\circ}$. The solid line represents the best fit of the data using the $P\left(E_{m m}\right)$ for process (1) shown in Fig. 6 (see the text). $v_{0}=1.64 \times 10^{5} \mathrm{~cm} / \mathrm{s}: \alpha=5.5 \times 10^{3} \mathrm{~cm} / \mathrm{s}$. 


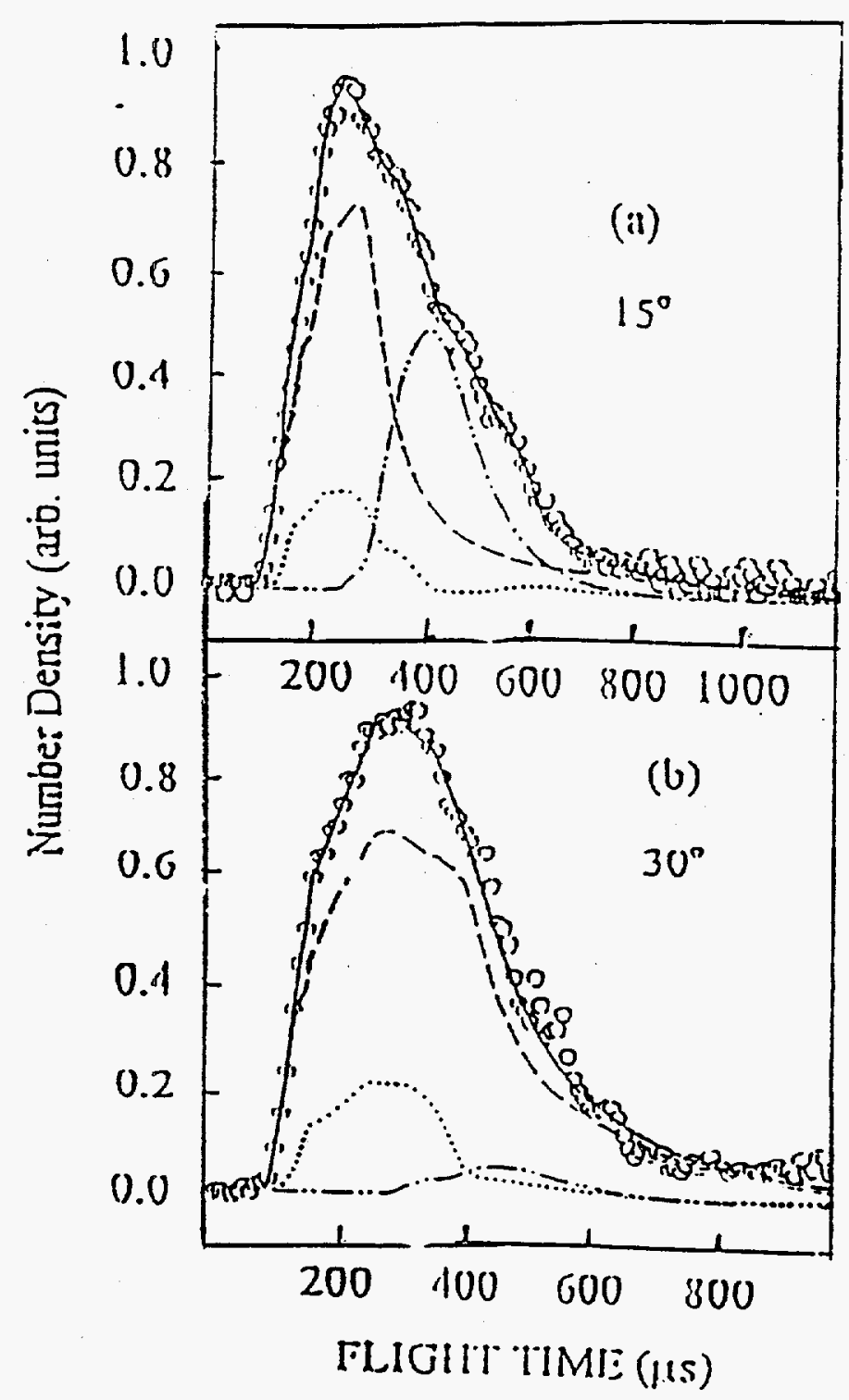

Figure 4. TOF spectra for $\mathrm{CH}_{3}$ obtained at (a) $\theta_{\mu b}=15^{\circ}$ and (b) $30^{\circ}$. Circles represent experimental data. Contributions are shown for $\mathrm{CH}_{3}(--)$ from process $(1), \mathrm{CH}_{3} \mathrm{SO}(-$ ..-) from process (1), and $\mathrm{CH}_{3}(\cdots)$ from process (3). The sum of these contributions are shown as the solid line. $v_{0}=1.56 \times 10^{3} \mathrm{~cm} / \mathrm{s} . \alpha=5.2 \times 10^{3} \mathrm{~cm} / \mathrm{s}$. 


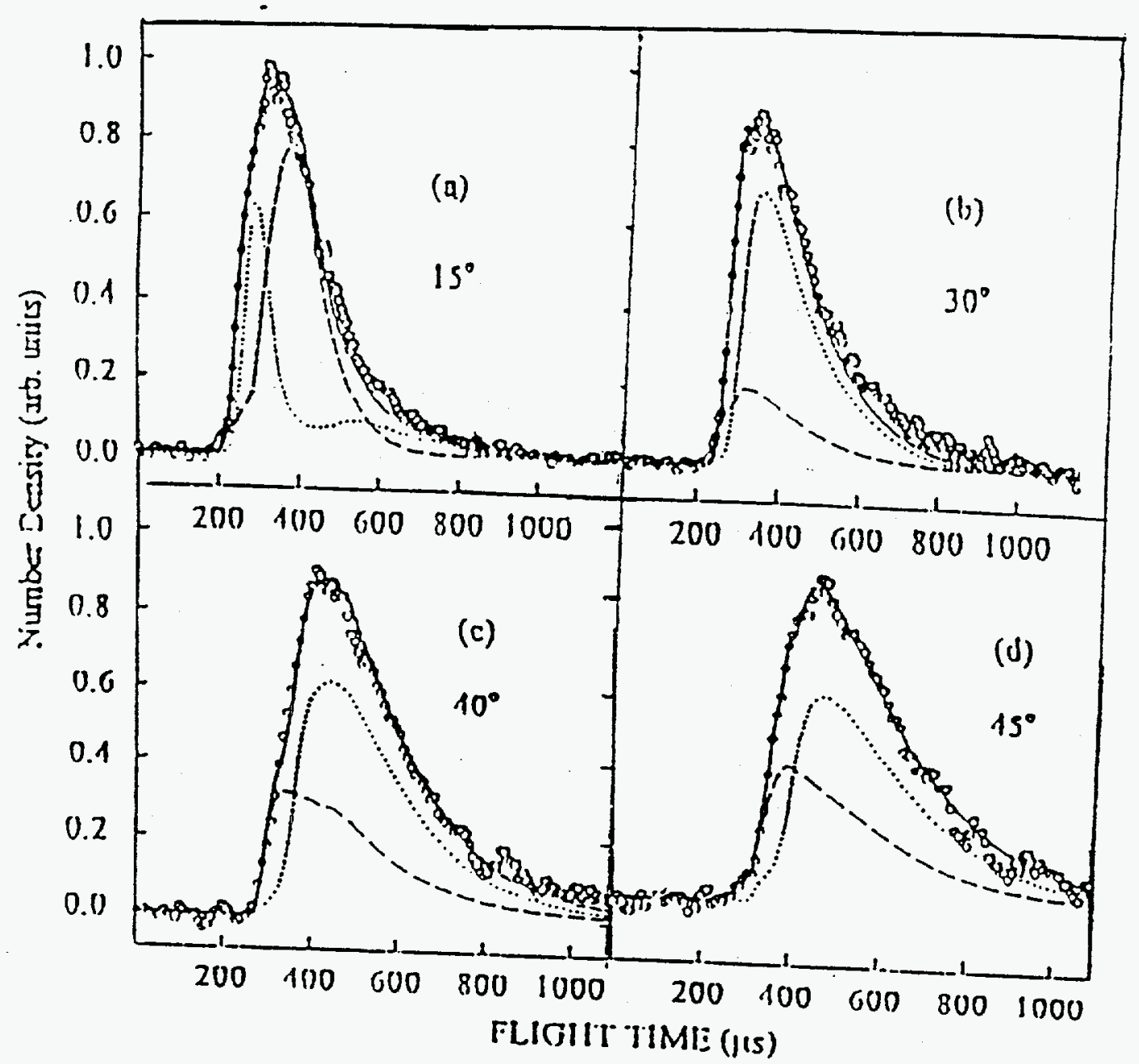

Figure 5. TOF spectra for SO obtained at $\theta_{\mathrm{Lb}}=$ (a) $15^{\circ}$, (b) $30^{\circ}$, (c) $40^{\circ}$, and (d) $45^{\circ}$. Contributions are shown for $\mathrm{CH}_{3} \mathrm{SO}(--)$ from process (1) and $\mathrm{SO}(\cdots)$ from process (3). The sum of these contributions are shown as the solid line. $v_{0}=1.64 \times 10^{3} \mathrm{~cm} / \mathrm{s}$. a $=5.5 \times 10^{3} \mathrm{~cm} / \mathrm{s}$. 


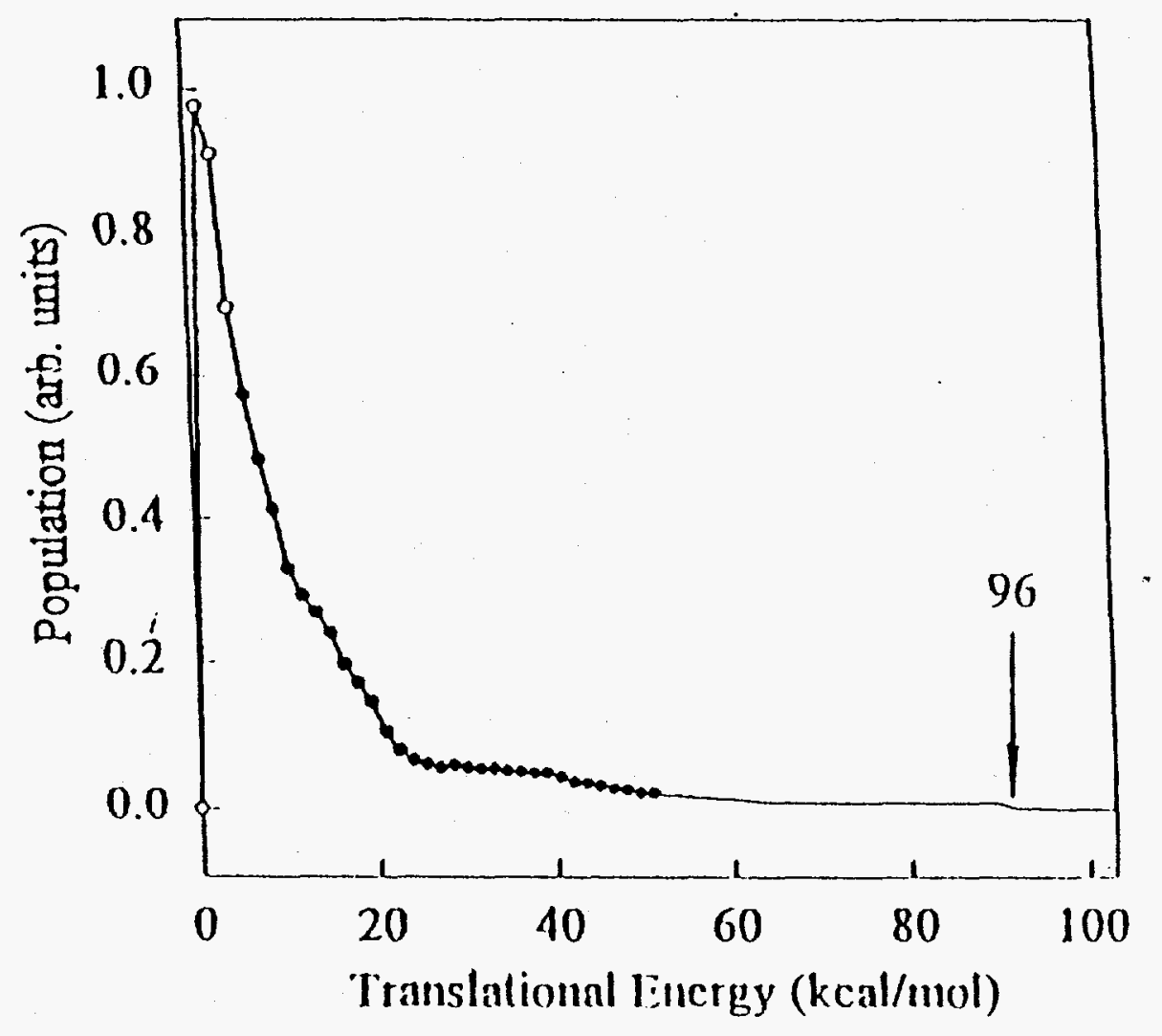

Figure 6. $\mathrm{E}_{\mathrm{c}, \mathrm{m}}$ distribution $\left[\mathrm{P}\left(\mathrm{E}_{\mathrm{c}, \mathrm{m}}\right)\right]$ for process (1) (solid line) derived by fitting the TOF spectra for $\mathrm{CH}_{3} \mathrm{SO}, \mathrm{CH}_{3}$, and $\mathrm{SO}$. The $\mathrm{P}\left(\mathrm{E}_{\mathrm{c} . \mathrm{m}}\right)$ derived from fitting the TOF spectrum of $\mathrm{CH}_{3} \mathrm{SO}$ is given in solid circles and the $\mathrm{P}\left(\mathrm{E}_{\mathrm{c} . \mathrm{m}}\right)$ derived by fitting the TOF spectra for $\mathrm{CH}_{3}$ is shown in open circles. 
obtained decreases rapidly from $E_{c . m} \approx 6 \mathrm{kcal} / \mathrm{mol}$ toward higher $E_{\text {c.m, }}$, and appears to have small populations at $\mathrm{E}_{\mathrm{c.m} .}>60 \mathrm{kcal} / \mathrm{mol}$. We find that the fit to the $\mathrm{CH}_{3} \mathrm{SO}$ spectrum is not

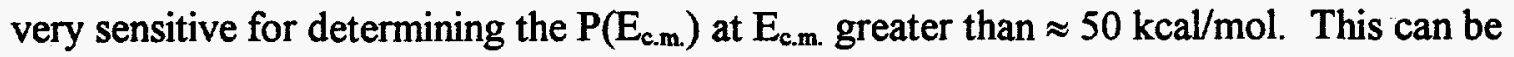
understood by the fact that $\mathrm{CH}_{3} \mathrm{SO}$ is the heavy moiety formed in process (1). The $\mathrm{P}\left(\mathrm{E}_{\mathrm{c.m}}\right)$ for process (1) near its $E_{\text {c.m. }}$ threshold can be more reliably determined using the TOF spectrum for $\mathrm{CH}_{3}$, the lighter moiety formed in process (1). The fact that the early parts of the TOF spectra for $\mathrm{CH}_{3}$ are contributed solely by $\mathrm{CH}_{3}$ formed in process (1) allows the derivation of the $P\left(E_{c . m}\right)$ at $E_{c . m}>60 \mathrm{kcal} / \mathrm{mol}$ of Fig. 6 (solid line) by fitting or direct transformation of the early part of the TOF spectra for $\mathrm{CH}_{3}$. We note that since the $\mathrm{E}_{\mathrm{c} . \mathrm{m} \text {. }}$ distribution for the excited $\mathrm{CH}_{3} \mathrm{SO}$ radicals, which have undergone further dissociation in the time scale of this experiment, has not been taken into account, the $P\left(E_{c . m}\right)$ obtained by fitting the TOF spectrum of $\mathrm{CH}_{3} \mathrm{SO}$ can only be considered as an estimate for the $\mathrm{P}\left(\mathrm{E}_{\mathrm{c.m}}\right)$ for process (1). Further modification of the $\mathrm{P}\left(\mathrm{E}_{\text {c.m. }}\right)$ derived from the $\mathrm{CH}_{3} \mathrm{SO}$ TOF spectrum is needed, especially at low $\mathrm{E}_{\text {c.m. }}$. where the population may have to be raised to obtain the correct $\mathrm{P}\left(\mathrm{E}_{\mathrm{c} . \mathrm{m}}\right)$ for process (1). This is due to the fact that primary $\mathrm{CH}_{3} \mathrm{SO}$ radicals with high internal energies $\left(\mathrm{E}_{\mathrm{int}}\right)$, which decompose and thus are not detected as $\mathrm{CH}_{3} \mathrm{SO}^{+}$in this experiment, correspond to the population at low $E_{c . m .}$ Nevertheless, the $P\left(E_{c . m .}\right)$ for process (1) seems to peak at low $\mathrm{E}_{\mathrm{c.m}}$ 's, consistent with the conclusion that the $\mathrm{CH}_{3} \mathrm{SO}$ and $\mathrm{CH}_{3}$ radicals formed by process (1) contain a significant amount of internal energies. Thus, the further dissociation of a portion of the internally excited $\mathrm{CH}_{3} \mathrm{SO}$ initially formed by process (1) is to be expected. 
The direct transformation of TOF data near the onset of the TOF spectra for $\mathrm{CH}_{3}$ reveals a weak, but distinct, onset at $E_{c . m .}=96 \pm 2 \mathrm{kcal} / \mathrm{mol}$ for the $P\left(E_{c . m}\right)$ of process (1). By energy conservation, we have the relationship

$\mathrm{E}(\mathrm{h} v)+\mathrm{E}_{\mathrm{int}}\left[\left(\mathrm{CH}_{3}\right)_{2} \mathrm{SO}\right]=\mathrm{D}_{0}\left(\mathrm{CH}_{3}-\mathrm{SOCH}_{3}\right)+\mathrm{E}_{\mathrm{c.m.}}+\mathrm{E}_{\mathrm{int}}\left(\mathrm{CH}_{3} \mathrm{SO}\right)+\mathrm{E}_{\mathrm{int}}\left(\mathrm{CH}_{3}\right)$

where $\mathrm{E}(\mathrm{hv}=193.3 \mathrm{~nm})=147.9 \mathrm{kcal} / \mathrm{mol}$ and $\mathrm{E}_{\mathrm{int}}\left[\left(\mathrm{CH}_{3}\right)_{2} \mathrm{SO}\right], \mathrm{E}_{\mathrm{int}}\left(\mathrm{CH}_{3} \mathrm{SO}\right)$, and $\mathrm{E}_{\text {int }}\left(\mathrm{CH}_{3}\right)$ represent the respective $\mathrm{E}_{\text {int }}$ values for $\left(\mathrm{CH}_{3}\right)_{2} \mathrm{SO}, \mathrm{CH}_{3} \mathrm{SO}$, and $\mathrm{CH}_{3}$. Assuming that $\mathrm{E}_{\text {int }}\left[\left(\mathrm{CH}_{3}\right)_{2} \mathrm{SO}\right]$ is negligible because of supersonic expansion, and that photofragments $\left(\mathrm{CH}_{3} \mathrm{SO}+\mathrm{CH}_{3}\right)$ formed at the threshold $\mathrm{E}_{\text {c.m. }}=96 \mathrm{kcal} / \mathrm{mol}$ contain no $\mathrm{E}_{\text {int, }}$ we calculate a value of $52 \pm 2 \mathrm{kcal} / \mathrm{mol}$ for $\mathrm{D}_{0}\left(\mathrm{CH}_{3}-\mathrm{SOCH}_{3}\right)$. Under the supersonic expansion conditions used in this experiment, the rotational relaxation for $\left(\mathrm{CH}_{3}\right)_{2} \mathrm{SO}$ is expected to be efficient. However, the vibrational relaxation for $\left(\mathrm{CH}_{3}\right)_{2} \mathrm{SO}$ is most likely incomplete. Using the calculated vibrational frequencies for $\left(\mathrm{CH}_{3}\right)_{2} \mathrm{SO}$, we estimate that the vibrational energy for $\left(\mathrm{CH}_{3}\right)_{2} \mathrm{SO}$ is $\approx 2.1 \mathrm{kcal} / \mathrm{mol}$ at $323 \mathrm{~K}$. If we assume that $\left(\mathrm{CH}_{3}\right)_{2} \mathrm{SO}$ is cooled to a vibrational temperature of $\approx 150 \mathrm{~K}$ after the supersonic expansion, a value of $53 \pm 2 \mathrm{kcal} / \mathrm{mol}$ is obtained for $\mathrm{D}_{0}\left(\mathrm{CH}_{3}-\mathrm{SOCH}_{3}\right)$, which is in agreement with the G2(MP2) prediction of $52.6 \mathrm{kcal} / \mathrm{mol}$. Combining the $\mathrm{D}_{0}\left(\mathrm{CH}_{3}-\mathrm{SOCH}_{3}\right)$ value determined here and the known $\mathrm{D}_{\mathrm{f}} \mathrm{H}_{0}^{\circ}$ values for $\left(\mathrm{CH}_{3}\right)_{2} \mathrm{SO}$ and $\mathrm{CH}_{3},{ }^{9}$ we calculate a value of $14.8 \pm 2.0 \mathrm{kcal} / \mathrm{mol}$ for $\mathrm{D}_{\mathrm{f}} \mathrm{H}^{\circ}{ }_{0}\left(\mathrm{CH}_{3} \mathrm{SO}\right)$, which is also consistent with the G2(MP2) prediction of $15.8 \mathrm{kcal} / \mathrm{mol}$ (see Table II).

The $\mathrm{SO}^{+}$ions can be formed by the dissociative ionization of $\mathrm{CH}_{3} \mathrm{SO}$. We note that the TOF spectrum for $\mathrm{CH}_{3} \mathrm{SO}$ [Fig. 3(a)] peaks at $\approx 370 \mu \mathrm{s}$, which is significantly later than the peak position of $\approx 320 \mu$ s for the SO TOF spectrum [Fig. 5(a)] at $\theta_{\mathrm{lab}}=15^{\circ}$. This 
observation indicates that the SO TOF spectrum is also contributed by other processes, such as process (2). This conclusion is consistent with previous $193.3 \mathrm{~nm}$ photodissociation studies of $\left(\mathrm{CH}_{3}\right)_{2} \mathrm{SO},{ }^{10,11}$ in which SO was identified as a nascent photoproduct and its rovibrational state distributions was measured using LIF techniques. The $\mathbf{P}\left(\mathrm{E}_{\mathrm{c} . \mathrm{m}}\right)$ for the concerted three-body photodissociation process $\left(\mathrm{CH}_{3}\right)_{2} \mathrm{SO}+\mathrm{hv} \rightarrow 2 \mathrm{CH}_{3}+\mathrm{SO}$ cannot be determined in this experiment. However, as we show in the discussion below, all TOF data obtained here can be satisfactorily fitted by assuming a stepwise mechanism for the formation of SO. The rough fitting of the SO spectrum at $\theta_{\mathrm{lab}}=15^{\circ}$ [Fig. 5(a)] shows that the majority of SO products formed by the secondary dissociation process (2) are faster than $\mathrm{CH}_{3} \mathrm{SO}$ produced by process (1). By introducing the secondary $\mathrm{P}\left(\mathrm{E}_{\mathrm{c} . \mathrm{m} .}\right)$ (Fig. 7) for the formation of $\mathrm{SO}+\mathrm{CH}_{3}$ by process (2), together with the estimated $\mathrm{P}\left(\mathrm{E}_{\mathrm{c.m}}\right)$ for process (1), we have obtained satisfactory fits all the TOF spectra of SO as shown in Figs. 5(a)-5(d). The angular distribution of the secondary $\mathrm{P}\left(\mathrm{E}_{\mathrm{c} . \mathrm{m}}\right)$ used in the fitting is isotropic. We note that the data fitting does not provide information about the secondary $P\left(E_{c . m}\right)$ at $E_{c . m}<4$ $\mathrm{kcal} / \mathrm{mol}$. As shown in Fig. 7, the $\mathrm{P}\left(\mathrm{E}_{\mathrm{c.m} . \mathrm{m}}\right)$ for the secondary dissociation process (2) obtained here decreases rapidly from $\mathrm{E}_{\mathrm{c.m} .} \approx 4 \mathrm{kcal} / \mathrm{mol}$ and has a $\mathrm{E}_{\mathrm{c} . \mathrm{m} .}$ threshold at $\approx 16$ $\mathrm{kcal} / \mathrm{mol}$.

The $\mathrm{CH}_{3}{ }^{+}$signals can be contributed by direct ionization of $\mathrm{CH}_{3}$ formed in processes (1) and (2) and the dissociative electron ionization of stable $\mathrm{CH}_{3} \mathrm{SO}$ formed in process (1). The estimated $P\left(E_{c . m .}\right)$ for process (1) (solid circles in Fig. 6) and the isotropic $P\left(E_{c . m}\right)$ for the secondary dissociation process (2) (Fig. 7) are used to fit the TOF spectra for $\mathrm{CH}_{3}$. Due to 


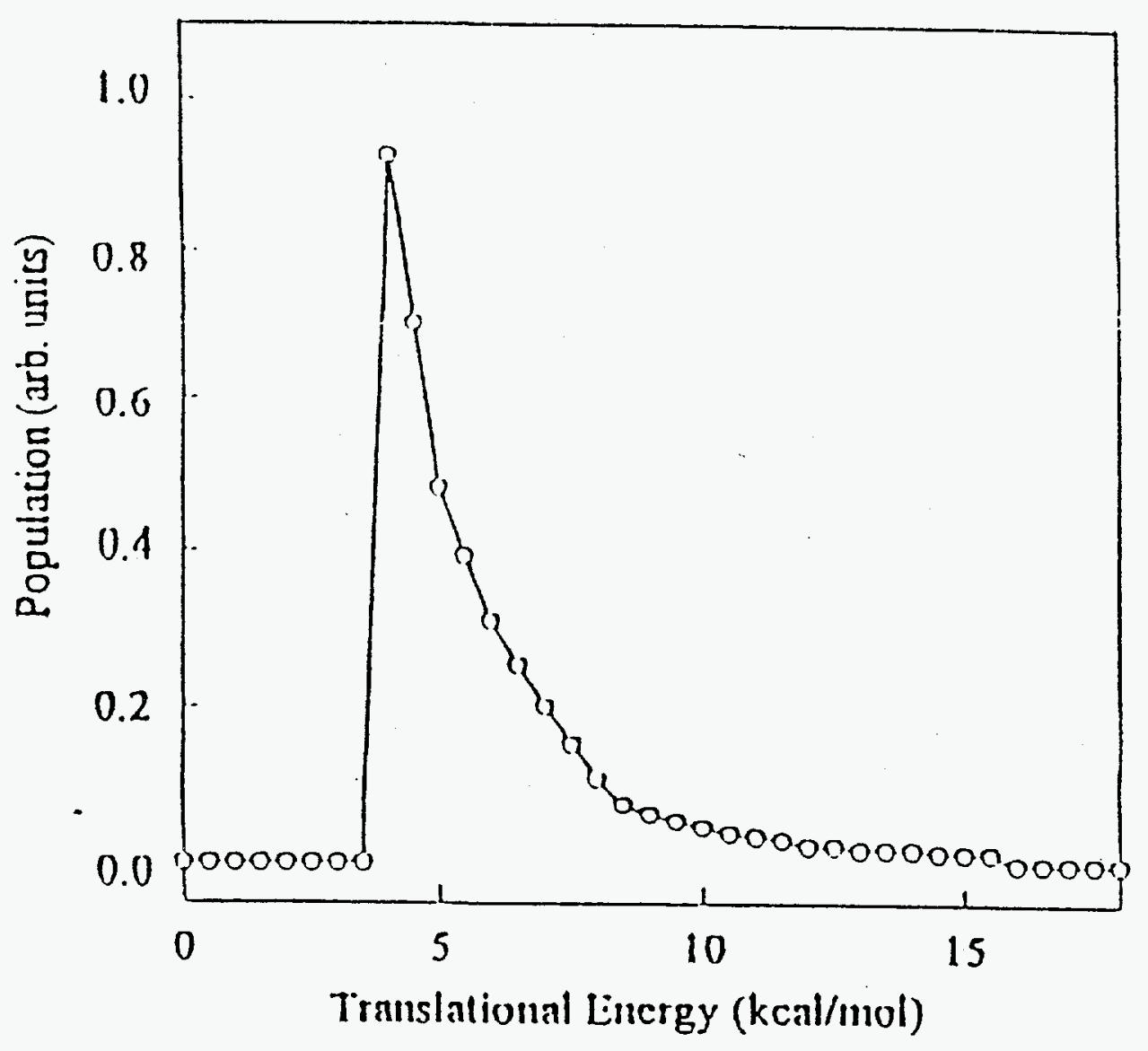

Figure 7. $P\left(\mathrm{E}_{\mathrm{cm}}\right)$ for the secondary dissociation process (3). The angular distriburion for this $P\left(E_{c m}\right)$ is assumed to be isotropic. We note that the fitting is not sensitive to $P\left(E_{c m}\right)$ at $\mathrm{E}_{\mathrm{cm}}<4 \mathrm{kcal} / \mathrm{mol}$. 
the momentum balance requirement, the TOF distribution of $\mathrm{CH}_{3}$ radicals which correlate with the stable $\mathrm{CH}_{3} \mathrm{SO}$ fragments can be predicted using the known TOF spectrum for $\mathrm{CH}_{3} \mathrm{SO}$. Here, the $\mathrm{CH}_{3}$ radicals formed in process (1) contain the contribution from $\mathrm{CH}_{3}$ radicals that are correlated with the excited $\mathrm{CH}_{3} \mathrm{SO}$ radicals (which have undergone further dissociation). The fitting of the TOF data for $\mathrm{CH}_{3}$ is expected to provide the correction needed for the estimated $P\left(E_{\text {c.m. }}\right)$ (solid circles in Fig. 6) at low $E_{\text {c.m. }}$. The open circles at $E_{\text {c.m. }}<6 \mathrm{kcal} / \mathrm{mol}$ shown in Fig. 6 are derived from fitting the TOF spectra for $\mathrm{CH}_{3}$. The careful fitting of the TOF spectra for $\mathrm{CH}_{3}$, SO, and $\mathrm{CH}_{3} \mathrm{SO}$ leads to the $\mathrm{P}\left(\mathrm{E}_{\mathrm{c.m}}\right)$ (solid line in Fig. 6) for process (1).

The fast peaks (dash-curves) shown in Figs. 4(a) and 4(b) account for the contribution by $\mathrm{CH}_{3}$ formed by process (1), while the slow peaks (dash-dot-curves) of the figures represent the contribution by stable $\mathrm{CH}_{3} \mathrm{SO}$. The dotted peaks shown in the TOF spectra for $\mathrm{CH}_{3}$ account for the contribution of $\mathrm{CH}_{3}$ formed in the secondary dissociation process (2). The fitting of the spectra of Fig. 4(a) and 4(b) also shows that the $\mathrm{CH}_{3}{ }^{+}$signals due to dissociative ionization of $\mathrm{CH}_{3} \mathrm{SO}$ become less important compared to that from $\mathrm{CH}_{3}$ formed by process (1) as $\theta_{\text {lab }}$ is increased. The fitting of the TOF data described above provides an estimate that $53 \%$ of $\mathrm{CH}_{3} \mathrm{SO}$ initially formed by process (1) undergoes further dissociation to produce $\mathrm{CH}_{3}+\mathrm{SO}$. That is, the quantum yield for $\mathrm{CH}_{3}$ formed in the $193 \mathrm{~nm}$ photodissociation of $\left(\mathrm{CH}_{3}\right)_{2} \mathrm{SO}$ is 1.53 . The latter value is arrived based on the assumption that $\mathrm{CH}_{3}$ radicals formed in different internal states have the same electron impact ionization cross sections. 
As shown in Table III, the G2(MP2) prediction of $55.1 \mathrm{kcal} / \mathrm{mol}$ for $\mathrm{D}_{0}\left(\mathrm{CH}_{3}-\mathrm{SO}\right)$ is only lower than the predicted value of $60.2 \mathrm{kcal} / \mathrm{mol}$ for $\mathrm{D}_{0}\left(\mathrm{H}-\mathrm{CH}_{2} \mathrm{SO}\right)$ by $5 \mathrm{kcal} / \mathrm{mol}$. Thus, it is energetically possible that excited $\mathrm{CH}_{3} \mathrm{SO}$ initially formed by process (1) might also dissociate to form planar $-\mathrm{CH}_{2} \mathrm{SO}+\mathrm{H}$. The TOF spectrum for $\mathrm{CH}_{2} \mathrm{SO}$ observed at $\theta=15^{\circ}$ is shown in Fig. 3(b). We find that this spectrum can be fitted by the $P\left(E_{c . m}\right)$ for process (1), indicating that the $\mathrm{CH}_{2} \mathrm{SO}^{+}$signals observed are due to dissociative electron ionization of $\mathrm{CH}_{3} \mathrm{SO}$. This, together with the failure to observe the TOF spectrum for $\mathrm{H}$, suggests that the further dissociation of internally excited $\mathrm{CH}_{3} \mathrm{SO}$ to form planar $-\mathrm{CH}_{2} \mathrm{SO}+\mathrm{H}$ is not a significant process.

Within the sensitivity of this experiment, no TOF signals for $\mathrm{O}$ atoms were observed. The mass for $\mathrm{CH}_{3} \mathrm{SCH}_{3}$ is identical to that of $\mathrm{CH}_{2} \mathrm{SO}$. Effort was made to observe the TOF signals for $\mathrm{CH}_{3} \mathrm{~S}^{+}$and $\mathrm{CH}_{2} \mathrm{~S}^{+}$, which are possible fragment ions formed in the dissociative electron ionization of $\mathrm{CH}_{3} \mathrm{SCH}_{3}$. Since the weak $\mathrm{CH}_{3} \mathrm{~S}^{+}$(mass 47) signal is only one mass away from the strong $\mathrm{SO}^{+}$(mass 48) signal, the TOF spectrum for $\mathrm{CH}_{3} \mathrm{~S}$ is affected and found to be similar to the SO TOF spectrum. We show in Fig. 3(c) the TOF spectrum for $\mathrm{CH}_{2} \mathrm{~S}^{+}$observed at $\theta_{\text {lab }}=15^{\circ}$. This spectrum is also found to stem from dissociative electron ionization of $\mathrm{CH}_{3} \mathrm{SO}$ because the spectrum can be fitted by the $\mathrm{P}\left(\mathrm{E}_{\mathrm{c} . \mathrm{m}}\right)$ for process (1). On the basis of this experiment, we conclude that process (3) is not important at $193.3 \mathrm{~nm} .{ }^{22}$ We note that both $\left(\mathrm{CH}_{3}\right)_{2} \mathrm{SO}$ and $\mathrm{CH}_{3} \mathrm{SCH}_{3}$ are closed shell molecules. The low probability for the formation of $\mathrm{CH}_{3} \mathrm{SCH}_{3}+\mathrm{O}\left({ }^{3} \mathrm{P}\right)$ by process (3) may be rationalized by its violation of the spin conservation rule. In order to conserve the total electron spin, the $\mathrm{O}$ atoms may be 
formed in the $O\left({ }^{1} \mathrm{D}\right)$ state. However, such a process requires $45.4 \mathrm{kcal} / \mathrm{mol}$ of additional energy (see Table III) ${ }^{23}$ making the formation of $\mathrm{O}\left({ }^{1} \mathrm{D}\right)$ energetically less favorable.

The angular distribution of the photofragments has the form: $P(\gamma)=1 / 4 \pi\left[1+\beta \mathrm{P}_{2}(\cos \gamma)\right]$, where $P_{2}(\cos \gamma)$ is the second Legendre polynomial and $\beta$ is the anisotropy parameter. The TOF spectra for SO observed at $\theta_{\mathrm{lab}}=15^{\circ}$ and $\varepsilon=30^{\circ}, 70^{\circ}, 90^{\circ}, 130^{\circ}$, and $170^{\circ}$ are shown in Fig. 8(b), while the SO spectra measured at $\theta=30^{\circ}$ and $\varepsilon=30^{\circ}, 70^{\circ}, 90^{\circ}, 130^{\circ}$, and $170^{\circ}$ are depicted in Fig. 8(c). We have also obtained the TOF spectra for $\mathrm{CH}_{3} \mathrm{SO}$ at $\theta_{\text {lab }}=15^{\circ}$ and $\varepsilon=0^{\circ}$ and $90^{\circ}$ [Fig. 8(a)]. Within the error limits of the experiment, no difference in the SO and $\mathrm{CH}_{3} \mathrm{SO}$ TOF spectra was observed, indicative of an isotropic distribution, i.e., $\beta=0$. We note that the data analysis of the SO TOF spectra suggests that both processes (1) and (2) contribute to the spectra at $\theta=15^{\circ}$ and $30^{\circ}$. The results of the measurements obtained here Contributions to the involves a $\mathrm{p} \rightarrow \mathrm{p}^{*}$ transition associated with the S-O bond, the breaking of the C-S bond likely proceeds via a predissociation mechanism. The observation of an isotropic distribution for the formation of $\mathrm{CH}_{3} \mathrm{SO}+\mathrm{CH}_{3}$ indicates that the predissociation lifetime is longer than the rotational period of the excited $\left(\mathrm{CH}_{3}\right)_{2} \mathrm{SO}$ precursor molecule. The observed $\mathrm{P}\left(\mathrm{E}_{\mathrm{c.m} . \mathrm{l}}\right)$ for process $(1)$ is close to that expected of a statistical unimolecular dissociation process, which likely involves a significant change in molecular geometry prior to dissociation. We note are consistent with the conclusion that the angular distribution for photoproducts of process (1) is isotropic. If the $193.3 \mathrm{~nm}$ excitation of $\left(\mathrm{CH}_{3}\right)_{2} \mathrm{SO}$ that the photofragments resulting from the $193.3 \mathrm{~nm}$ photodissociation of $\left(\mathrm{CH}_{3}\right)_{2} \mathrm{CO}$ are also found to have an isotropic distribution. ${ }^{24,25}$ 

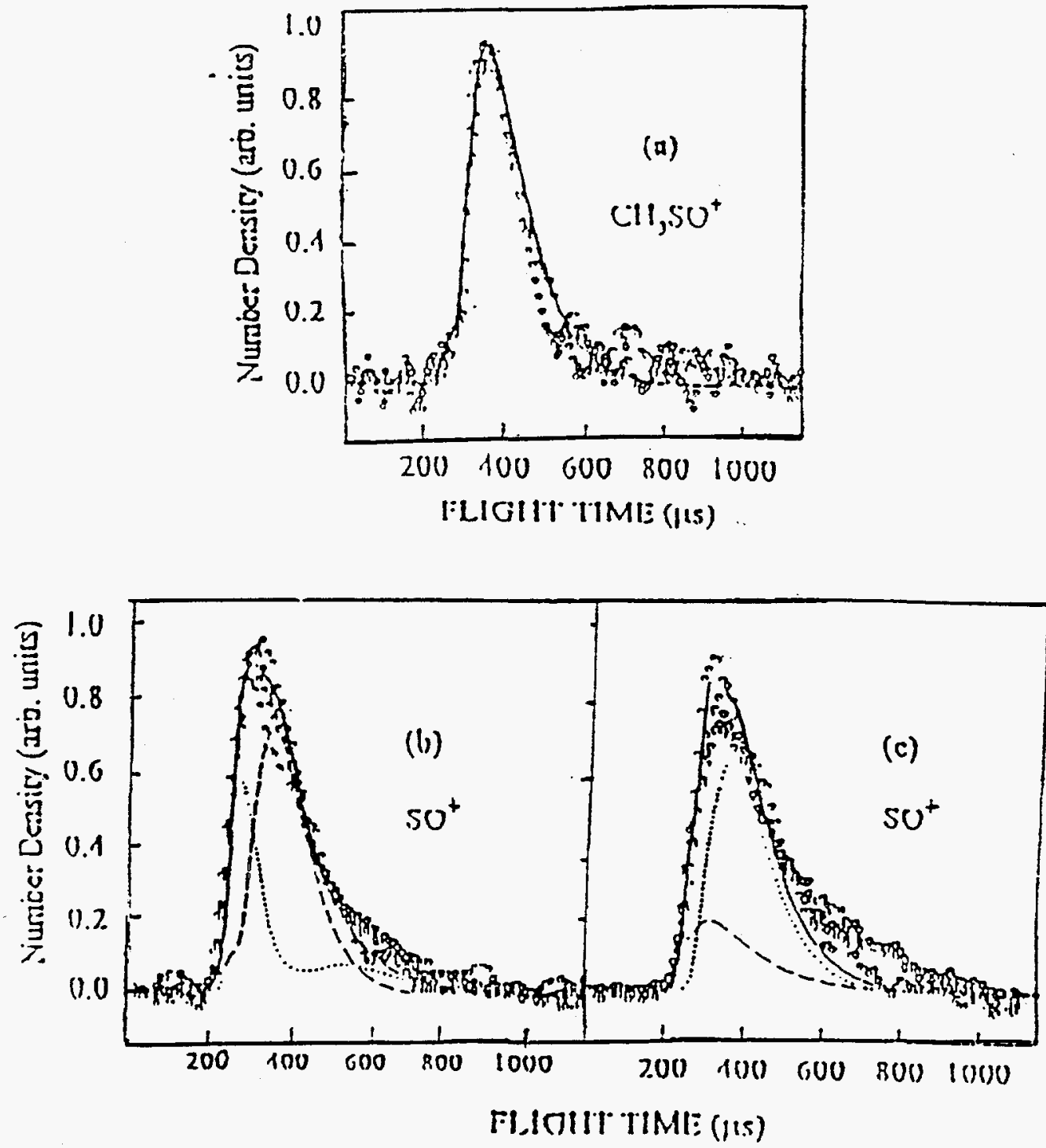

Figure 8. (a) The TOF spectra for $\mathrm{CH}_{3} \mathrm{SO}$ (a) observed at $\mathrm{e}_{\mathrm{tab}}=15^{\circ}$ and $\varepsilon=0^{\circ}$ and $90^{\circ}$. (b) The TOF spectra for $S O$ observed at $\theta_{\text {lab }}=15^{\circ}$ and $\varepsilon=30^{\circ}, 70^{\circ}, 90^{\circ}, 130^{\circ}$, and $170^{\circ}$. (c) The TOF spectra for $S O$ observed at $e_{12 b}=30^{\circ}$ and $\varepsilon=30^{\circ}, 70^{\circ}, 50^{\circ}, 130^{\circ}$, and $170^{\circ}$. SO TOF spectra are shown for $\mathrm{CH}_{3} \mathrm{SO}(--)$ from process (1) and $\mathrm{SO}(.$.$) from$ process (3). The sum of these contributions are stown as the solid line. $v_{0}=$ $1.64 \times 10^{5} \mathrm{~cm} / \mathrm{s} . \alpha=5.5 \times 10^{3} \mathrm{~cm} / \mathrm{s}$. 


\section{Conclusion}

The product channels resulting from the $193.3 \mathrm{~nm}$ photofragmentation of $\left(\mathrm{CH}_{3}\right)_{2} \mathrm{SO}$ have been investigated by the molecular beam TOF mass spectrometric technique. The results of this experiment show that $\mathrm{CH}_{3} \mathrm{SO}, \mathrm{CH}_{3}$ and $\mathrm{SO}$ are the dominant photoproducts. The $E_{\text {c.m. }}$ energy distribution for photofragments of process (1) is found to peak at $E_{c . m .} \approx 3$ $\mathrm{kcal} / \mathrm{mol}$, indicating that the $\mathrm{CH}_{3} \mathrm{SO}$ and $\mathrm{CH}_{3}$ are formed with considerable internal energies. The data analysis suggests that $\approx 53 \%$ of the $\mathrm{CH}_{3} \mathrm{SO}$ radicals initially formed by process (1) undergo spontaneous dissociation to form $\mathrm{CH}_{3}+\mathrm{SO}$, yielding a quantum yield of $\approx 1.53$ for $\mathrm{CH}_{3}$ formed in the $193 \mathrm{~nm}$ photodissociation of $\left(\mathrm{CH}_{3}\right)_{2} \mathrm{SO}$. Within the sensitivity of this experiment, photodissociation leading to the formation of $\mathrm{CH}_{3} \mathrm{SCH}_{3}+\mathrm{O}$ is not found. The unfavorable production of $\mathrm{CH}_{3} \mathrm{SCH}_{3}+\mathrm{O}\left({ }^{3} \mathrm{P}\right)$ is attributed to the violation of the spin conservation rule.

On the basis of the $\mathrm{E}_{\text {c.m. }}$ threshold determined by the TOF spectrum of $\mathrm{CH}_{3}$, we obtain a value of $53 \pm 2 \mathrm{kcal} / \mathrm{mol}$ for $\mathrm{D}_{0}\left(\mathrm{CH}_{3} \mathrm{SO}-\mathrm{CH}_{3}\right)$, in excellent agreement with the prediction at the G2(MP2) level of theory. This measurement yields a value of $-14.8 \pm 2.0 \mathrm{kcal} / \mathrm{mol}$ for $\mathrm{D}_{\mathrm{f}} \mathrm{H}^{\circ}\left(\mathrm{CH}_{3} \mathrm{SO}\right)$.

The angular distribution measurements indicate that the photofragments of processes (1) have an isotropic distribution. This observation is consistent with a predissociation mechanism for photoexcited $\left(\mathrm{CH}_{3}\right)_{2} \mathrm{SO}$ with a lifetime longer than its rotation period. 


\section{References}

(1) C.-W. Hsu, C.-L. Liao, Z.-X. Ma, and C. Y. Ng, J. Phys. Chem. 99, 1760 (1995).

(2) C. E. M. Strauss and P. L. Houston, J. Phys. Chem. 94, 8751 (1990).

(3) K. A. Trentelman, S. H. Kable, D. B. Moss, and P. L. Houston, J. Chem. Phys. 91, $7498(1989)$

(4) S. W. North, D. A. Blank, J. D. Gezelter, C. A. Longfellow, and Y. T. Lee, J. Chem. Phys. 102, 4447 (1995).

(5) S. K. Kim, S. Pederson, and A. H. Zewail, J. Chem. Phys. 103, 477 (1995). We note that the experiments of Refs. 4 and 5 were conducted at different photodissociation energies. Thus, the excited dissociation states involved in the two experiments are also different.

(6) K. Gollnick and H. U. Stracke, Pure Appl. Chem. 33, 217 (1973).

(7) K. Gollnick and H. U. Stracke, Tetrahedron Lett. 203 (1971).

(8) K. Gollnick and H. U. stracke, Tetrahedron Lett. 207 (1971).

(9) S. G. Lias, J. E. Bartmess, J. F. Liebman, J. L. Holmes, R. D. Levin, and W. G. Mallard, J. Phys. Chem. Ref. Data, 17 (1988), suppl. No. 1.

(10)X. Chen, F. Asmar, H. Wang, and B. R. Weiner, J. Phys. Chem. 95,6415 (1991).

(11)X. Chen, H. wang, B. R. Weiner, M. Hawley, and H. H. Nelson, J. Phys. Chem. 97, 12269 (1993).

(12) S. W. Benson, Chem. Rev. 78, 23 (1978). 
(13)L. A. Curtiss, K. Raghavachari, G. W. Trucks and J. A. Pople, J. Chem. Phys. 94, 7221 (1991).

(14)L. A. Curtiss, K. Raghavachari and J. A. Pople, J. Chem. Phys. 98, 1293 (1993).

(15)W.-B. Tzeng, H.-M. Yin, W.-Y. Leung, J.-Y. Luo, S. Nourbakhsh, G. D. Flesch, and C. Y. Ng, J. Chem. Phys. 88, 1658 (1988)

(16) T. K. Minton, G. M. Nathanson, and Y. T. Lee, J. Chem. Phys. 86, 1991 (1987).

(17)E. J. Hintsa, X. Zhao, and Y. T. Lee, J. Chem. Phys. 92, 2280 (1990).

(18)X. Zhao, Ph.D. thesis, University of California, Berkeley, CA, 1988.

(19)M. J. Frisch et al., Gaussian 94 (Gaussian, Pittsburgh, PA 1994).

(20) S.-W. Chiu, W.-K. Li, W.-B. Tzeng, and C. Y. Ng, J. Chem. Phys. 97, 6557 (1992).

(21)H. Bock and B. Solouki, Angew. Chem. 72, 618 (1960).

(22) We found that when the temperature for the container of the dimethylsulfoxide sample was increased to ${ }^{3} 350 \mathrm{~K}$, a fast peak was observed in the TOF for $\mathrm{CH}_{3}$. This fast peak is attributed to $\mathrm{CH}_{3}$ formed by the $193 \mathrm{~nm}$ photodissociation of $\mathrm{CH}_{3} \mathrm{SCH}_{3}$, which is produced by pyrolytic processes in the sample container.

(23)H. Okabe, Photochemistry of Small Molecules (Wiley, New York, 1978).

(24)G. Hancock and K. R. Wilson, in Proceedings, IVth International Symposium on Molecular Beams, Cannes, France, 1973.

(25) L. D. Waits, R. J. Horwitz, and J. A. Guest, Chem. Phys. 155, 149 (1991). 


\title{
193 NM LASER PHOTOFRAGMENTATION TIME-OF-FLIGHT MASS
}

\section{SPECTROMETRIC STUDY OF $\mathrm{HSCH}_{2} \mathrm{CH}_{2} \mathrm{SH}$}

\author{
A paper submitted to the Journal of Chemical Physics \\ H.-Q. Zhao, Y.-S. Cheung, C.-X. Liao, and C. Y. Ng
}

\begin{abstract}
The kinetic energy release spectra for SH resulting from the $193 \mathrm{~nm}$ laser photofragmentation of $\mathrm{HSCH}_{2} \mathrm{CH}_{2} \mathrm{SH}$ have been measured. On the basis of the observed maximum kinetic energy for the formation of $\mathrm{HS}+\mathrm{CH}_{2} \mathrm{CH}_{2} \mathrm{SH}$, a value of $74 \pm 2 \mathrm{kcal} / \mathrm{mol}$ is derived for the bond dissociation energy of $\mathrm{HS}-\mathrm{CH}_{2} \mathrm{CH}_{2} \mathrm{SH}$ at $0 \mathrm{~K}\left[\mathrm{D}_{0}\left(\mathrm{HS}-\mathrm{CH}_{2} \mathrm{CH}_{2} \mathrm{SH}\right]\right.$. Angular distribution measurements for SH yield an anisotropic parameter $\beta=-0.4 \pm 0.1$ for the $\mathrm{HS}+\mathrm{CH}_{2} \mathrm{CH}_{2} \mathrm{SH}$ channel, indicating that the $\mathrm{C}-\mathrm{S}$ bond fission is fast with respect to molecular rotation. The energetics for the formation of $\mathrm{HS}+\mathrm{CH}_{2} \mathrm{CH}_{2} \mathrm{SH}$ from $\mathrm{HSCH}_{2} \mathrm{CH}_{2} \mathrm{SH}$ have been investigated using the Gaussian-2 (G2) and G2(MP3) ab initio quantum chemical procedures. The G2/G2(MP3) calculations give a prediction of 72.5 $\mathrm{kcal} / \mathrm{mol}$ for $\mathrm{D}_{0}\left(\mathrm{HS}-\mathrm{CH}_{2} \mathrm{CH}_{2} \mathrm{SH}\right)$, in excellent agreement with the experimental value. $A b$ initio first-order configuration interaction calculations have also been made to examine the possible excited state of $\mathrm{HSCH}_{2} \mathrm{CH}_{2} \mathrm{SH}$ involved in the photodissociation process and to rationalize the observed angular distribution for the $\mathrm{HS}+\mathrm{CH}_{2} \mathrm{CH}_{2} \mathrm{SH}$ channel.

\section{Introduction}

Volatile organosulfur molecules are produced as atmospheric pollutants by combustion of fossil fuels as well as by natural sources. ${ }^{1-4}$ Radicals formed in the
\end{abstract}


atmospheric ultraviolet (UV) breakdown of organosulfur pollutants are intermediates in the atmospheric sulfur cycles and have the effect of accelerating the oxidation of organosulfur pollutants, leading to the formation of $\mathrm{SO}_{2}{ }^{5-7}$ Acid rain results when sulfur-containing compounds, including $\mathrm{SO}_{2}$, are removed from the atmosphere by rain or snow. Thus, laboratory UV laser photodissociation of volatile organosulfur species is relevant to the modeling of atmospheric sulfur chemistry cycles. In an effort to obtain energetic information and to identify the primary product channels resulting from the UV photolysis of organosulfur pollutants, we have performed UV laser photodissociation and photoionization studies of a series of volatile sulfur-containing species in recent years. ${ }^{8-22}$

These experimental studies indicate that the 193 ( or 248 ) nm laser photodissociation of sulfur-containing hydrocarbons often involves prompt breakage of $\mathrm{C}-\mathrm{S}$ and $\mathrm{S}-\mathrm{H}$ bonds with little structural rearrangement. For example, $\mathrm{CH}_{3} \mathrm{~S}\left(\mathrm{CH}_{3} \mathrm{CH}_{2} \mathrm{~S}\right)$ is found to be the primary isomer formed in the $193 \mathrm{~nm}$ photodissociation of $\mathrm{CH}_{3} \mathrm{SH}\left(\mathrm{CH}_{3} \mathrm{CH}_{2} \mathrm{SH}\right)$ and $\mathrm{CH}_{3} \mathrm{SCH}_{3}\left(\mathrm{CH}_{3} \mathrm{CH}_{2} \mathrm{SCH}_{2} \mathrm{CH}_{3}\right){ }^{10-13,18,21,23-28}$ This observation is consistent with the interpretation that a repulsive excited electronic potential surface along the $\mathrm{C}-\mathrm{S}$ ( or $\mathrm{S}-\mathrm{H}$ ) coordinate is formed by direct photoexcitation and/or by rapid intramolecular access following photoexcitation, resulting in the prompt $\mathrm{C}-\mathrm{S}$ ( or S-H) bond scission. ${ }^{23-26}$ On the basis of this understanding, along with the high dissociation cross sections, organosulfur compounds are excellent molecular precursors for the preparation of polyatomic radicals with a specific isomeric structure using the UV excimer laser photodissociation method. 
In recent experiments, the energetics, such as ionization energies and heats of formation at $0 \mathrm{~K}\left(\Delta_{\mathrm{f}} \mathrm{H}_{0}{ }^{\circ} \mathrm{s}\right)$, for two of the $\mathrm{C}_{2} \mathrm{H}_{5} \mathrm{~S}$ isomers $\mathrm{CH}_{3} \mathrm{CH}_{2} \mathrm{~S}$ and $\mathrm{CH}_{3} \mathrm{SCH}_{2}$, have been characterized. ${ }^{18,29} \mathrm{Ab}$ initio calculations indicate that $\mathrm{CH}_{2} \mathrm{CH}_{2} \mathrm{SH}$ is also a stable isomer for $\mathrm{C}_{2} \mathrm{H}_{5} \mathrm{~S}$. The $193 \mathrm{~nm}$ laser photofragment time-of-flight (TOF) mass spectrometric experiment reported here is designed in part to measure the energetics of the $\mathrm{CH}_{2} \mathrm{CH}_{2} \mathrm{SH}$ radical, which is expected to be the primary product resulting from the $\mathrm{C}-\mathrm{S}$ bond scission process,

$$
\mathrm{HSCH}_{2} \mathrm{CH}_{2} \mathrm{SH}+\mathrm{hv}(193 \mathrm{~nm}) \rightarrow \mathrm{HS}+\mathrm{CH}_{2} \mathrm{CH}_{2} \mathrm{SH}
$$

In addition to determining the bond dissociation energy at $0 \mathrm{~K}\left(\mathrm{D}_{0}\right)$ for $\mathrm{HS}-\mathrm{CH}_{2} \mathrm{CH}_{2} \mathrm{SH}$, the kinetic energy release and the angular distribution of process (1) are obtained.

Since the $\Delta_{\mathrm{f}} \mathrm{H}_{0}{ }^{\circ}$ values for $\mathrm{CH}_{2} \mathrm{CH}_{2} \mathrm{SH}$ and $\mathrm{HSCH}_{2} \mathrm{CH}_{2} \mathrm{SH}$ are not known, we have performed ab initio quantum chemical calculations on these species at the Gaussian-2 (G2) level of theory. ${ }^{30,31}$ These calculations provide the important energetic information needed for the analysis of the TOF data obtained in this study. Ab initio first-order configuration interaction (FOCI) calculations ${ }^{32}$ for several low lying excited electronic states of $\mathrm{HSCH}_{2} \mathrm{CH}_{2} \mathrm{SH}$ also shed light on the mechanism of process (1).

\section{Experimental and Theoretical Methods}

\section{A. Experiment}


The rotatable beam source laser photofragmentation apparatus used in this study has been described in detail previously. ${ }^{8-14}$ The apparatus consists of three main components; an ArF excimer laser, a photodissociation chamber in which a rotatable supersonic molecular beam intersects with the laser beam, and a linearly movable ultrahigh vacuum electron ionization quadrupole mass spectrometer.

A molecular beam of $\mathrm{HSCH}_{2} \mathrm{CH}_{2} \mathrm{SH}$ was produced by supersonic expansion through a nozzle with a diameter of $0.125 \mathrm{~nm}$. The beam has an angular divergence of $\approx 3^{\circ}$, which is defined by the opening of the conical skimmer and by the circular aperture between the differential pumping chamber and the photodissociation chamber. The $3^{\circ}$ angular spread of the beam gives a beamwidth of $3 \mathrm{~mm}$ in the photodissociation region. For the measurements at the laboratory angles $\left(\theta_{\text {lab }}\right)$ ( defined by the direction of molecular beam with respect to the detector axis) of $30^{\circ}$ and $45^{\circ}$, the ratio of the pressure of $\mathrm{HSCH}_{2} \mathrm{CH}_{2} \mathrm{SH}$ to that of $\mathrm{He}$ was about $2 \%$. The nozzle temperature $\left(T_{0}\right)$ and the total stagnation pressure $\left(P_{0}\right)$ were maintained at $333 \mathrm{~K}$ and 560 Torr, respectively. For the measurements at $\theta_{\mathrm{lab}}=70^{\circ}$ and $90^{\circ}$, the pressure ratio and $\mathrm{T}_{0}$ were increased to $12 \%$ and $403 \mathrm{~K}$, respectively. We also obtained TOF spectra at $\theta_{\mathrm{lab}}=70^{\circ}$ and $5^{\circ}$ (not shown here). At these $\theta$ values, the influence of clusters and dimmers cannot be avoided, even though $\mathrm{P}_{0}$ was reduced to 150 Torr and $\mathrm{T}_{0}$ was increased to $453 \mathrm{~K}$.

All TOF spectra were taken at a flight path of $65.5 \mathrm{~cm}$, the distance between the photodissociation region and the electron impact ionizer. The ionization electron energy was $75 \mathrm{eV}$. 
The energy of the excimer laser (Questek model 2460) used was varied in the range of 30-55 mJ. This energy range was used to minimize two-photon dissociation processes. The laser beam enters the photodissociation chamber through a $\mathrm{MgF}_{2}$ focusing lens and is perpendicular to the seeded $\mathrm{HSCH}_{2} \mathrm{CH}_{2} \mathrm{SH}$ beam.

The TOF spectra presented here were recorded on a multichannel scaler (Stanford Research model SRT430) with a channel width of $1.28 \mu \mathrm{s}$. The ion drift times though the quadrupole mass filter were determined to be $4.114 \mathrm{~m}^{1 / 2}$, where $\mathrm{m}$ is the ion mass. The actual flight times of photofragments were corrected for the corresponding ion drift times. The velocity distribution of the parent $\mathrm{HSCH}_{2} \mathrm{CH}_{2} \mathrm{SH}$ beam was determined by taking the laser hole burning spectra of $\mathrm{HSCH}_{2} \mathrm{CH}_{2} \mathrm{SH}^{+}$at $\theta=0^{0}$. The measured speed profile of species was then fitted to an assumed functional form, ${ }^{8,33} \mathrm{f}(\mathrm{v}) \sim \mathrm{v}^{2} \exp \left[-\left(\mathrm{v}-\mathrm{v}_{0}\right)^{2} / \alpha^{2}\right]$, where $\mathrm{v}_{0}$ is the most probable speed and $\alpha$ is a measure of the width of the speed profile. For the $\mathrm{HSCH}_{2} \mathrm{CH}_{2} \mathrm{SH}$ to He seeding ratio of $2 \%, \mathrm{~T}_{0}=333 \mathrm{~K}$, and $\mathrm{P}_{0}=560$ Torr, we found that $\mathrm{v}_{0}=1.65 \times 10^{5} \mathrm{~cm} / \mathrm{s}$ and $\alpha=0.65 \times 10^{4} \mathrm{~cm} / \mathrm{s}$, while $\mathrm{v}_{0}=1.31 \times 10^{5} \mathrm{~cm} / \mathrm{s}$ and $\alpha=0.65 \times 10^{4} \mathrm{~cm} / \mathrm{s}$ for the $\mathrm{HSCH}_{2} \mathrm{CH}_{2} \mathrm{SH}$ to He seeding ratio of $12 \%, \mathrm{~T}_{0}=403 \mathrm{~K}$, and $\mathrm{P}_{0}=560$ Torr.

The analysis of the TOF data was performed by a forward simulation method. ${ }^{34-36}$. Briefly, the procedure began with a trial kinetic energy distribution $\mathrm{P}\left(\mathrm{E}_{\mathrm{c.m} .}\right)$, which was transformed to a TOF spectrum for comparison with the experimental TOF spectrum. Here, $E_{c . m .}$ represents the center-of-mass kinetic energy of the photofragments. The $p\left(E_{c . m}\right)$ distribution was adjusted until satisfactory agreement between the experimental and calculated TOF data was obtained. For the determination of the kinetic energy threshold for 
process (1), the $P\left(E_{c . m}\right)$ distribution near the $E_{c . m}$ onset was obtained by direct transformation ${ }^{8}$ of the TOF data.

In the measurements of the angular distribution, the laser light was polarized by a stack of ten quartz plates set at the Brewster angle. The electric vector $\mathbf{E}$ of the polarized laser beam was set perpendicular to the detector and then rotated into the desired direction with a half-wave retarder. The laser energy was measured by a pyroelectric detector, and was kept at $10 \mathrm{~mJ} / \mathrm{pulse}$. The $\theta_{\text {lab }}$ value was set at $45^{\circ}$ with respect to the detector axis, and the $\mathrm{HSCH}_{2} \mathrm{CH}_{2} \mathrm{SH}$ to $\mathrm{He}$ seeding ratio was $9 \%, \mathrm{~T}_{0}=403 \mathrm{~K}$, and $\mathrm{P}_{0}=360$ Torr. In order to determine the angular distribution for process (1), the TOF spectrum for SH was recorded in the interval of $\varepsilon \approx 50^{\circ}$ with each spectrum accumulated for a fixed number of laser shots. Here, $\varepsilon$ is the angle between $\mathbf{E}$ and the direction of the molecular beam. The detector axis, the molecular beam axis, and $\mathbf{E}$ are in the same plane, which is perpendicular to the laser propagation direction.

\section{B. $A b$ initio Calculations}

The Gaussian-2 (G2) ab initio theoretical procedure has been described in detail by Curtiss et al ${ }^{30}$ Briefly, at the G2 level of theory, molecular structures are optimized with the Hartree-Fock (HF) approach and the second-order Mфller-Plesset perturbation theory (MP2) with all electrons included using the 6-31G(d) basis set [i.e., at the HF/6-31G(d) and MP2(full)/6-31G(d) levels]. Harmonic vibrational frequencies are calculated at the HF/6$31 \mathrm{G}(\mathrm{d})$ geometry for stationary point characterization. All subsequent single-point calculations at higher levels involved are based on the MP2/6-31G(d) optimized structures. 
Approximations of $Q C I S D(T) / 6-311+G(3 d f, 2 p)$ energies are obtained with frozen-core single-point calculations at the QCISD(T)/6-311G(d, p), MP4/6-311G(d, p), MP4/6-311 + $G(d, p), M P 4 / 6-311 G(2 d f, p)$, and MP2/6-311 + G(3df, 2p) levels. A small semiempirical correction is applied to account for high level correction effects to obtain the total electronic energy $\left(E_{c}\right)$. The HF/6-31G(d) harmonic vibrational frequencies, scaled by 0.8929 , are used for zero-point vibrational energy (ZPVE) correction. The total energy at $0 \mathrm{~K}\left(\mathrm{E}_{0}\right)$ is equal to $\mathrm{E}_{\mathrm{e}}+\mathrm{ZPVE}$

The G2(MP3) theory ${ }^{31}$ is a variation of the G2 procedure in which all the MP4 single-point energies are replaced by the corresponding MP3 energies. The correction for high level correlation effects in the G2(MP3) theory is also slightly different from that in the G2 procedure. The G2(MP3) theory, which provides substantial savings in computational time and disk storage, has been tested on the same set of 125 systems used for validation of the G2 theory. The average absolute deviations of G2(MP3) theory from experiment are only $\leq 0.4 \mathrm{kcal} / \mathrm{mol}$. In view of the large size of $\mathrm{HSCH}_{2} \mathrm{CH}_{2} \mathrm{SH}$, the G2(MP3) method was used for this molecule and the $\mathrm{G} 2$ theory was used for the smaller $\mathrm{CH}_{2} \mathrm{CH}_{2} \mathrm{SH}$ molecule. All calculations were carried out on IBM RS6000-320h and RS6000/340 workstations or CRAY-YMP and CRAY-2 using the GAUSSIAN 90 and GAUSSIAN 92 package programs. ${ }^{17}$

For $\mathrm{HSCH}_{2} \mathrm{CH}_{2} \mathrm{SH}$, a number of rotational isomers with different conformations were obtained. The most stable isomer of $\mathrm{HSCH}_{2} \mathrm{CH}_{2} \mathrm{SH}$ at the MP2/6-31G(d) level has $\mathrm{C}_{2 \mathrm{~h}}$ symmetry (Fig. 1). In order to study the $\mathrm{HS}-\mathrm{CH}_{2} \mathrm{CH}_{2} \mathrm{SH}$ bond cleavage process, we also performed calculations on $\mathrm{CH}_{2} \mathrm{CH}_{2} \mathrm{SH}$. At the MP2/6-31G(d) level, two isomers were 
(a)

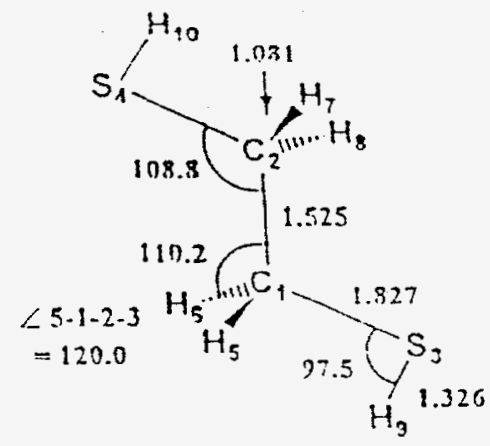

$115 \mathrm{C} \mathrm{H}_{2} \mathrm{CH} 1_{2} \mathrm{SH}\left(\mathrm{C}_{21}\right)$
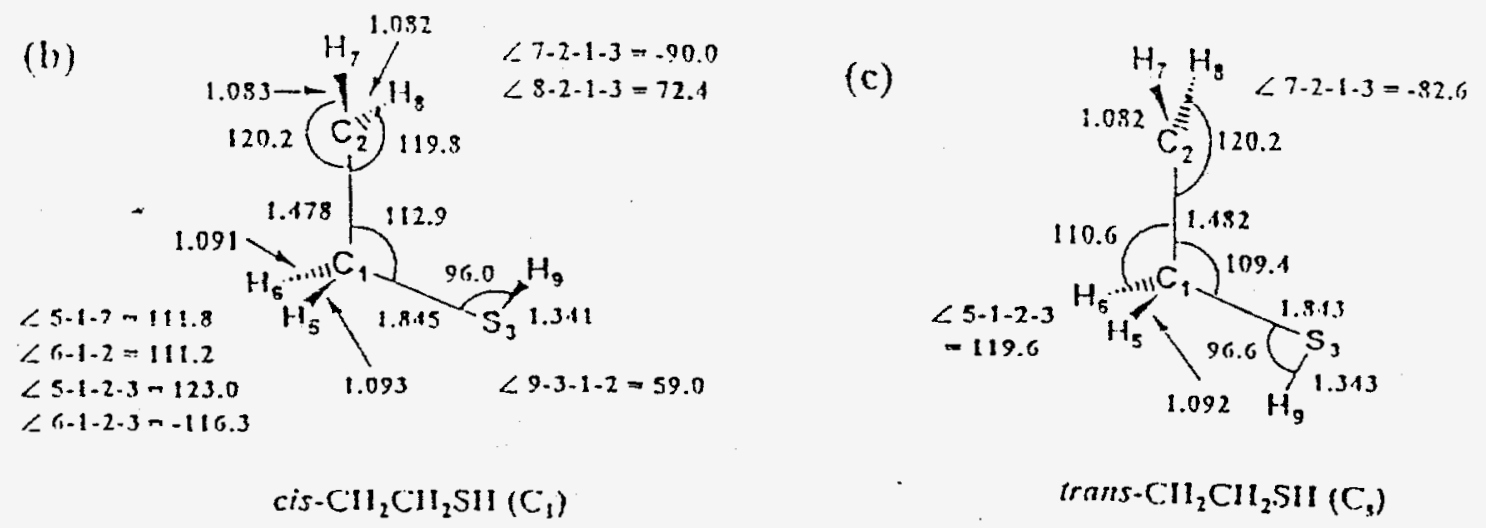

Figure 1. The structures of (a) $\mathrm{HSCH}_{2} \mathrm{CH}_{2} \mathrm{SH}\left(\mathrm{C}_{2 \mathrm{~h}}\right)$, (b) cis- $\mathrm{CH}_{2} \mathrm{CH}_{2} \mathrm{SH}\left(\mathrm{C}_{1}\right)$, and (c) trans$\mathrm{CH}_{2} \mathrm{CH}_{2} \mathrm{SH}\left(\mathrm{C}_{3}\right)$ optimized at the MP2/6-31G(d) level. 
obtained for $\mathrm{CH}_{2} \mathrm{CH}_{2} \mathrm{SH}$ with $\mathrm{Cs}$ and $\mathrm{Cl}$ symmetries (Fig. 1). The $\mathrm{CH}_{2} \mathrm{CH}_{2} \mathrm{SH}\left(\mathrm{C}_{1}\right)$ structure is a cis-isomer with the $\mathrm{H}$ attached to $\mathrm{S}$ and the terminal $\mathrm{CH}_{2}$ group in the cis positions, whereas the $\mathrm{CH}_{2} \mathrm{CH}_{2} \mathrm{SH}\left(\mathrm{C}_{8}\right)$ structure is the trans-isomer with the terminal $\mathrm{H}$ and $\mathrm{CH}_{2}$ group in the trans positions [i.e. $\angle \mathrm{H}(9)-\mathrm{S}(3)-\mathrm{C}(1)-\mathrm{C}(2)=180^{\circ}$ ]. We note that the structure for the $-\mathrm{CH}_{2} \mathrm{SH}$ entity in $\mathrm{CH}_{2} \mathrm{CH}_{2} \mathrm{SH}\left(\mathrm{C}_{\mathrm{s}}\right)$ and $\mathrm{HSCH}_{2} \mathrm{CH}_{2} \mathrm{SH}$ are similar. The $\mathrm{CH}_{2} \mathrm{SH}$ entity in $\mathrm{CH}_{2} \mathrm{CH}_{2} \mathrm{SH}\left(\mathrm{C}_{1}\right)$ is also similar in geometry to that in the parent molecule $\mathrm{HCH}_{2} \mathrm{CH}_{2} \mathrm{SH}\left(\mathrm{C}_{2 \mathrm{~h}}\right)$ other than the difference in conformation. The $\mathrm{CH}_{2} \mathrm{CH}_{2} \mathrm{SH}\left(\mathrm{C}_{1}\right)$ isomer is more stable than the $\mathrm{CH}_{2} \mathrm{CH}_{2} \mathrm{SH}\left(\mathrm{C}_{\mathrm{s}}\right)$ isomer by only $1.2 \mathrm{kcal} / \mathrm{mol}$ at the $\mathrm{G} 2$ level. Although the structure of $-\mathrm{CH}_{2} \mathrm{SH}$ in cis- and trans $-\mathrm{CH}_{2} \mathrm{CH}_{2} \mathrm{SH}$ are similar to that in $\mathrm{HSCH}_{2} \mathrm{CH}_{2} \mathrm{SH}\left(\mathrm{C}_{2 \mathrm{~h}}\right)$, significant changes in geometry of the terminal methylene group in $\mathrm{CH}_{2} \mathrm{CH}_{2} \mathrm{SH}$ are observed . The $\angle \mathrm{C}(1)-\mathrm{C}(2)-\mathrm{H}(7)$ and $\angle \mathrm{C}(1)-\mathrm{C}(2)-\mathrm{H}(8)$ changes from $110.2^{\circ}$ in $\mathrm{HSCH}_{2} \mathrm{CH}_{2} \mathrm{SH}\left(\mathrm{C}_{2 \mathrm{~h}}\right)$ to $120.2^{\circ}$ and $119.8^{\circ}$ in $\mathrm{CH}_{2} \mathrm{CH}_{2} \mathrm{SH}\left(\mathrm{C}_{1}\right)$, respectively. The $\angle \mathrm{H}(7)-\mathrm{C}(2)-\mathrm{C}(1)-\mathrm{S}(8)$ in $\mathrm{HSCH}_{2} \mathrm{CH}_{2} \mathrm{SH}\left(\mathrm{C}_{2 \mathrm{~h}}\right)$ is $120.0^{\circ}$ and becomes $162.4^{\circ}$ in $\mathrm{CH}_{2} \mathrm{CH}_{2} \mathrm{SH}\left(\mathrm{C}_{\mathrm{s}}\right)$. That is, the atoms $\mathrm{C}(1), \mathrm{C}(2), \mathrm{H}(7)$, and $\mathrm{H}(8)$ are almost coplanar, indicating that the hybridization of $\mathrm{C}(2)$ changes from $\mathrm{sp}^{3}$ in $\mathrm{HSCH}_{2} \mathrm{CH}_{2} \mathrm{SH}$ to $\mathrm{sp}^{2}$ in $\mathrm{CH}_{2} \mathrm{CH}_{2} \mathrm{SH}$, as expected for an alkyl radical.

The $\mathrm{E}_{0}[\mathrm{G} 2(\mathrm{MP} 3)]$ and $\Delta_{\mathrm{f}} \mathrm{H}_{0}{ }^{\circ}[\mathrm{G} 2(\mathrm{MP} 3)]$ values for $\mathrm{HSCH}_{2} \mathrm{CH}_{2} \mathrm{SH}$ and $\mathrm{E}_{0}(\mathrm{G} 2)$ and $\Delta_{\mathrm{f}} \mathrm{H}_{0}{ }^{\circ}(\mathrm{G} 2)$ values for $\mathrm{SH},{ }^{30} \mathrm{CH}_{2} \mathrm{CH}_{2},{ }^{30} \mathrm{CH}_{2} \mathrm{SH},{ }^{38}$ and cis- and trans- $\mathrm{CH}_{2} \mathrm{CH}_{2} \mathrm{SH}$ are listed in Table I. The $\Delta_{\mathrm{f}} \mathrm{H}_{0}{ }^{\circ}(\mathrm{G} 2)$ values are obtained using the experimental ${ }^{39} \Delta_{\mathrm{f}} \mathrm{H}_{0}{ }^{\circ}$ values of $\mathrm{C}$ (170 kcal/mol), $\mathrm{H}(51.6 \mathrm{kcal} / \mathrm{mol})$, and $\mathrm{S}(65.6 \mathrm{kcal} / \mathrm{mol})$ and $\mathrm{E}_{0}(\mathrm{G} 2)($ Ref. 24$)$ values of $\mathrm{C}$ (-37.78432 hartree), H(-0.50000 hartree), and S (-397.65495 hartree). The 
TABLE I. G2[or G2(MP3)] total energies $\left(\mathrm{E}_{0}\right)$ and $\Delta_{\mathrm{f}} \mathrm{H}_{0}{ }^{\circ}$ values for $\mathrm{SH}, \mathrm{C}_{2} \mathrm{H}_{4}, \mathrm{CH}_{2} \mathrm{SH}$, $\mathrm{C}_{2} \mathrm{H}_{5} \mathrm{~S}$ isomers, and $\mathrm{HSCH}_{2} \mathrm{CH}_{2} \mathrm{SH}$.

\begin{tabular}{|c|c|c|c|}
\hline Species & $E_{0}[\mathrm{G} 2 \text { or } \mathrm{G} 2(\mathrm{MP} 3)]^{a}$ & $\begin{array}{c}\Delta_{\mathrm{f}} \mathrm{H}_{0}{ }^{\circ}[\mathrm{G} 2 \text { or } \mathrm{G} 2(\mathrm{MP} 3)]^{2, \mathrm{~b}} \\
(\mathrm{kcal} / \mathrm{mol})\end{array}$ & $\begin{array}{l}\Delta_{\mathrm{f}} \mathrm{H}_{0}{ }^{\circ}(\operatorname{expt})^{\mathrm{c}} \\
(\mathrm{kcal} / \mathrm{mol})\end{array}$ \\
\hline $\mathrm{HSCH}_{2} \mathrm{CH}_{2} \mathrm{SH}\left(\mathrm{C}_{2 \mathrm{~h}}\right)$ & -875.11395 & 3.4 & $\ldots$ \\
\hline cis- $\mathrm{CH}_{2} \mathrm{CH}_{2} \mathrm{SH}\left(\mathrm{C}_{1}\right)$ & -476.71323 & 41.5 & $\ldots$ \\
\hline trans- $\mathrm{CH}_{2} \mathrm{CH}_{2} \mathrm{SH}\left(\mathrm{C}_{3}\right)$ & $-476.71304^{d}$ & 42.7 & $\ldots$ \\
\hline $\mathrm{CH}_{3} \mathrm{CH}_{2} \mathrm{~S}\left(\mathrm{C}_{\mathrm{s}}\right)$ & $-476.73761^{d}$ & $27.5^{\mathrm{d}}$ & $31.4 \pm 2^{\mathrm{c}}$ \\
\hline cis- $\mathrm{CH}_{3} \mathrm{CHSH}\left(\mathrm{C}_{1}\right)$ & $-476.72512^{d}$ & $35.3^{\mathrm{d}}$ & $\ldots$ \\
\hline trans- $\mathrm{CH}_{3} \mathrm{CHSH}\left(\mathrm{C}_{1}\right)$ & $-476.72459^{d}$ & $35.6^{\mathrm{d}}$ & $\ldots$ \\
\hline $\mathrm{CH}_{3} \mathrm{SCH}_{2}\left(\mathrm{C}_{1}\right)$ & $-476.72189^{d}$ & $37.3 \mathrm{~d}$ & $\begin{array}{l}34.8 \pm 2.5^{\mathrm{f}} \\
35.2 \pm 1.6^{\mathrm{g}}\end{array}$ \\
\hline $\mathrm{CH}_{2} \mathrm{SH}$ & $-437.49655^{\mathrm{h}}$ & $40.8^{h}$ & $37.7 \pm 2.0$ \\
\hline $\mathrm{CH}_{2} \mathrm{CH}_{2}$ & $-78.41593^{i}$ & $14.7^{i}$ & $14.5 \pm 0.2$ \\
\hline SH & $-398.286^{\mathrm{h}}$ & $34.4^{\mathrm{h}}$ & $32.6 \pm 1.2$ \\
\hline
\end{tabular}

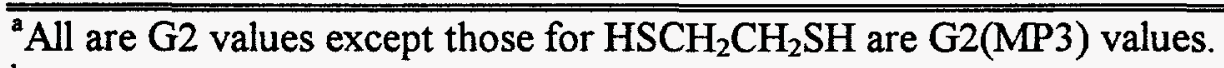

${ }^{b}$ Calculated using the experimental $\Delta_{\mathrm{f}} \mathrm{H}_{0}{ }^{\circ}$ values of $\mathrm{C}(170.0 \mathrm{kcal} / \mathrm{mol}), \mathrm{H}(51.63 \mathrm{kcal} / \mathrm{mol})$, and $\mathrm{S}(65.6 \pm 0.1 \mathrm{kcal} / \mathrm{mol})$ from Ref. $39 ; \mathrm{E}_{0}(\mathrm{G} 2)$ values of $\mathrm{C}(-37.78432$ hartree), H(0.50000 hartree) and $\mathrm{S}\left(-397.65495\right.$ hartree) from Ref. 30; and $\mathrm{E}_{0}[\mathrm{G} 2(\mathrm{MP} 3)]$ values of C(-37.78432 hartree), H(-0.50000 hartree) and S (-397.65326 hartree) from Ref. 31 . ${ }^{c}$ Experimental $\Delta_{\mathrm{f}} \mathrm{H}_{0}{ }^{\circ}$ values. Unless specified, values are from Ref. 39.

${ }^{\mathrm{d}}$ Reference 18.

${ }^{\mathrm{e}}$ Reference 12.

${ }^{\mathrm{f}}$ Reference 10.

${ }^{B}$ Reference 42.

${ }^{h}$ Reference 38.

'Reference 30. 
$\Delta_{\mathrm{f}} \mathrm{H}_{0}{ }^{\circ}[\mathrm{G} 2(\mathrm{MP} 3)]$ for $\mathrm{HSCH}_{2} \mathrm{CH}_{2} \mathrm{SH}$ is calculated using the same experimental $\Delta_{\mathrm{f}} \mathrm{H}_{0}{ }^{\circ}$ for $\mathrm{C}$, $\mathrm{S}$, and $\mathrm{H}$, the $\mathrm{E}_{0}[\mathrm{G} 2(\mathrm{MP} 3)]$ values for $\mathrm{C}, \mathrm{S}$, and $\mathrm{H}$ from Ref. 40 and for $\mathrm{HSCH}_{2} \mathrm{CH}_{2} \mathrm{SH}$ obtained in this study. The theoretical and experimental results ${ }^{10,12,18,41}$ obtained recently for the energetics of other $\mathrm{C}_{2} \mathrm{H}_{5} \mathrm{~S}$ isomers $\left(\mathrm{CH}_{3} \mathrm{CH}_{2} \mathrm{~S}, \mathrm{CH}_{3} \mathrm{SCH}_{2}\right.$, and cis/trans- $\left.\mathrm{CH}_{3} \mathrm{CHSH}\right)$ are also included in the table.

To shed light on the excited potential energy surfaces responsible for process (1), we also calculated the vertical excitation energies for several low lying excited states of $\mathrm{HSCH}_{2} \mathrm{CH}_{2} \mathrm{SH}$ based on the FOCI method. The $1 \mathrm{~s}, 2 \mathrm{~s}$, and $2 \mathrm{p}$ orbitals for sulfur atoms and the $1 \mathrm{~s}$ orbitals for carbon atoms were treated as core orbitals and were kept frozen in the FOCI calculations. In order to properly describe the possible diffuse nature of the excited orbitals of $\mathrm{HSCH}_{2} \mathrm{CH}_{2} \mathrm{SH}$, we used for each of the sulfur and carbon atoms. All calculations on the excited states of $\mathrm{HSCH}_{2} \mathrm{CH}_{2} \mathrm{SH}$ were performed on an IBM RS6000/340 workstation using the GAMESS program. ${ }^{32}$

The electronic configuration for the ground $\mathrm{HSCH}_{2} \mathrm{CH}_{2} \mathrm{SH}\left(\mathrm{C}_{2 \mathrm{~h}}, \mathrm{X}^{1} \mathrm{~A}_{\mathrm{g}}\right)$ state is $\ldots\left(9 b_{u} 10 a_{g} 3 b_{g} 3 a_{u}\right)^{2}\left(11 a_{g}\right)^{0}$. The occupied molecular orbitals $9 b_{u}, 10 a_{g}, 3 b_{g}$, and $3 a_{u}$ are mainly contributed by the four lone-pairs(nonbonding orbitals) of the sulfur atoms, while the 6-31 $+G(d, p)$ basis set, which includes a set of diffuse atomic orbitals the virtual molecular orbital $11 \mathrm{a}_{\mathrm{g}}$ has appreciable antibonding character for the C-S bonds. The FOCI calculations indicate that the excited states with vertical excitation energies $<8.5 \mathrm{eV}$ are: 1 ${ }^{1} \mathrm{~A}_{\mathrm{u}}(5.9 \mathrm{eV}), 1{ }^{1} \mathrm{~B}_{\mathrm{g}}(6.0 \mathrm{eV}), 2{ }^{1} \mathrm{~B}_{\mathrm{g}}(6.8 \mathrm{eV}), 2{ }^{1} \mathrm{~A}_{\mathrm{u}}(6.9 \mathrm{eV}), 3{ }^{1} \mathrm{~B}_{\mathrm{g}}(8.1 \mathrm{eV}), 3{ }^{1} \mathrm{~A}_{\mathrm{u}}(8.2 \mathrm{eV}) .2$ 
${ }^{1} \mathrm{~A}_{\mathrm{g}}(8.3 \mathrm{eV})$, and $1{ }^{1} \mathrm{~B}_{\mathrm{u}}(8.5 \mathrm{eV})$, where the values in parentheses are the corresponding vertical excitations from the ground $\mathrm{X}^{1} \mathrm{~A}_{\mathrm{g}}$ state.

\section{Results and Discussion}

On the basis of the previous $193 \mathrm{~nm}$ photodissociation study of $\mathrm{CH}_{3} \mathrm{CH}_{2} \mathrm{SH},{ }^{12}$ the absorption of a $193 \mathrm{~nm}$ laser photon by $\mathrm{HSCH}_{2} \mathrm{CH}_{2} \mathrm{SH}$ may induce the production of $\mathrm{HS}+$ $\mathrm{CH}_{2} \mathrm{CH}_{2} \mathrm{SH}$ [process (1)], $\mathrm{H}+\mathrm{SCH}_{2} \mathrm{CH}_{2} \mathrm{SH}$, and/or $2 \mathrm{CH}_{2} \mathrm{SH}$. Other than the TOF signal for $\mathrm{SH}$, we have also searched carefully the TOF spectra for $\mathrm{CH}_{2} \mathrm{CH}_{2} \mathrm{SH}, \mathrm{CH}_{2} \mathrm{SH}, \mathrm{CH}_{2}$, $\mathrm{CH}_{2} \mathrm{CH}_{2}$, and $\mathrm{H}$ at beam angles of $10^{\circ}, 15^{\circ}, 20^{\circ}$, and $30^{\circ}$. Within the sensitivity of this experiment, the spectra for these species are not observed. Thus, we conclude that HS + $\mathrm{CH}_{2} \mathrm{CH}_{2} \mathrm{SH}$ is overwhelmingly the major product channel. We note that the $\mathrm{CH}_{3} \mathrm{CH}_{2}+\mathrm{SH}$ channel, which involves the C-S bond scission, is also the major product channel in the 193 $\mathrm{nm}$ photodissociation of $\mathrm{CH}_{3} \mathrm{CH}_{2} \mathrm{SH}$. As is evidenced in the analysis given below, the electron impact ionization of $\mathrm{CH}_{2} \mathrm{CH}_{2} \mathrm{SH}$ produced in process (1) yields predominantly $\mathrm{SH}^{+}$

$$
\mathrm{CH}_{2} \mathrm{CH}_{2} \mathrm{SH}+\mathrm{e}^{-} \rightarrow \mathrm{CH}_{2} \mathrm{CH}_{2}+\mathrm{SH}^{+}+2 \mathrm{e}^{-}
$$

Since the experimental $\Delta \mathrm{fH}_{0}{ }^{\circ}$ values for both $\mathrm{HSCH}_{2} \mathrm{CH}_{2} \mathrm{SH}$ and $\mathrm{CH}_{2} \mathrm{CH}_{2} \mathrm{SH}$ are not available, the $\mathrm{D}_{0}\left(\mathrm{HS}-\mathrm{CH}_{2} \mathrm{CH}_{2} \mathrm{SH}\right)$ is unknown. Table II compares the experimental 11, 12 and G2[or G2(MP3)] theoretical ${ }^{38} \mathrm{D}_{0}$ values for the $\mathrm{CH}_{3}-\mathrm{SH}, \mathrm{CH}_{3} \mathrm{CH}_{2}-\mathrm{SH}$, and HS$\mathrm{CH}_{2} \mathrm{CH}_{2} \mathrm{SH}$. The theoretical value for $\mathrm{D}_{0}\left(\mathrm{HS}-\mathrm{CH}_{2} \mathrm{CH}_{2} \mathrm{SH}\right)$ is calculated using the $\mathrm{G} 2$ values for $\Delta_{\mathrm{f}} \mathrm{H}_{0}{ }^{\circ}$ (cis- and trans- $\mathrm{CH}_{2} \mathrm{CH}_{2} \mathrm{SH}$ ) and $\Delta_{\mathrm{f}} \mathrm{H}_{0}{ }^{\circ}(\mathrm{SH})$ and the G2(MP3) value for 
TABLE II. Bond dissociation energies at $0 \mathrm{~K}\left(\mathrm{D}_{0}\right)$ and the most probable c.m. kinetic $\left[\left(E_{c . m}\right)_{m p}\right]$ and internal $\left[\left(E_{\mathrm{int}}\right)_{\mathrm{mp}}\right]$ energies of fragments formed in the $193 \mathrm{~nm}$ photolysis of $\mathrm{CH}_{3} \mathrm{SH}, \mathrm{CH}_{3} \mathrm{CH}_{2} \mathrm{SH}$, and $\mathrm{HSCH}_{2} \mathrm{CH}_{2} \mathrm{SH}$.

\begin{tabular}{lcccc}
\hline \multicolumn{1}{c}{ Process } & $\begin{array}{c}\mathrm{D}_{0}(\mathrm{theor})^{\mathrm{a}} \\
(\mathrm{kcal} / \mathrm{mol})\end{array}$ & $\begin{array}{c}\mathrm{D}_{0}(\mathrm{expt}) \\
(\mathrm{kcal} / \mathrm{mol})\end{array}$ & $\%\left(\mathrm{E}_{\mathrm{c} . \mathrm{m}}\right)_{\mathrm{mp}}$ & $\%\left(\mathrm{E}_{\text {int }}\right)_{\mathrm{mp}}$ \\
\hline $\mathrm{CH}_{3} \mathrm{SH}+\mathrm{hv}(193 \mathrm{~nm}) \rightarrow \mathrm{CH}_{3}+\mathrm{SH}$ & $73.0^{\mathrm{b}}$ & $72.4 \pm 1.5^{\mathrm{c}}$ & $70^{\mathrm{c}}$ & $30^{\mathrm{c}}$ \\
& & & $79 \mathrm{~d}$ & $21^{\mathrm{d}}$ \\
$\mathrm{CH}_{3} \mathrm{CH}_{2} \mathrm{SH}+\mathrm{hv}(193 \mathrm{~nm}) \rightarrow \mathrm{CH}_{3} \mathrm{CH}_{2}+\mathrm{SH}$ & $\ldots$ & $72.3 \pm 1.5^{\mathrm{e}}$ & $46^{\mathrm{e}}$ & $54^{\mathrm{e}}$ \\
$\mathrm{HSCH} \mathrm{CH}_{2} \mathrm{SH}+\mathrm{hv}(193 \mathrm{~nm}) \rightarrow \mathrm{HS}+\mathrm{CH}_{2} \mathrm{CH}_{2} \mathrm{SH} 72.5^{\mathrm{f}}$ & $74 \pm 2$ & 40 & 60 \\
& & $73.7^{\mathrm{g}}$ & & \\
$\mathrm{HSCH}_{2} \mathrm{CH}_{2} \mathrm{SH} \rightarrow 2 \mathrm{CH}_{2} \mathrm{SH}$ & & & & $\ldots$ \\
$\mathrm{CH}_{2} \mathrm{CH}_{2} \mathrm{SH} \rightarrow \mathrm{CH}_{2} \mathrm{CH}_{2}+\mathrm{SH}$ & 77.3 & $\ldots$ & $\ldots$ & $\ldots$ \\
\hline \hline
\end{tabular}

${ }^{2}$ Values calculated using $\Delta_{\mathrm{f}} \mathrm{H}_{0}{ }^{\circ}(\mathrm{G} 2)$ and $\Delta_{\mathrm{f}} \mathrm{H}_{0}{ }^{\circ}$ [G2(MP3)] predictions given in Table $\mathrm{I}$.

${ }^{\mathrm{b}}$ Reference 38, ${ }^{\mathrm{C}}$ Reference 11, ${ }^{\mathrm{d}}$ Reference 23, ${ }^{\mathrm{e}}$ Reference 12.

Value corresponds to the formation of cis- $\mathrm{CH}_{2} \mathrm{CH}_{2} \mathrm{SH}$.

${ }^{g}$ Value corresponds to the formation of trans $-\mathrm{CH}_{2} \mathrm{CH}_{2} \mathrm{SH}$. 
$\mathrm{HSCH}_{2} \mathrm{CH}_{2} \mathrm{SH}$. The $\mathrm{G} 2 \mathrm{D}_{0}\left(\mathrm{HS}-\mathrm{CH}_{2} \mathrm{CH}_{2} \mathrm{SH}\right)$ values for the formation $\mathrm{HS}+c i s-\mathrm{CH}_{2} \mathrm{CH}_{2} \mathrm{SH}$ and $\mathrm{HS}+$ trans $-\mathrm{CH}_{2} \mathrm{CH}_{2} \mathrm{SH}$ are 72.5 and $73.7 \mathrm{kcal} / \mathrm{mol}$, respectively. In view of the fact that $\mathrm{D}_{0}\left(\mathrm{CH}_{3}-\mathrm{SH}\right)=72.4 \pm 1.5 \mathrm{kcal} / \mathrm{mol}(\mathrm{Ref} .11)$ is essentially identical to $\mathrm{D}_{0}\left(\mathrm{CH}_{3} \mathrm{CH}_{2^{-}}\right.$ $\mathrm{SH})=72.3 \pm 1.5 \mathrm{kcal} / \mathrm{mol},{ }^{12}$ we expect that $\mathrm{D}_{0}\left(\mathrm{HS}-\mathrm{CH}_{2} \mathrm{CH}_{2} \mathrm{SH}\right)$ has a value similar to those for $\mathrm{D}_{0}\left(\mathrm{CH}_{3}-\mathrm{SH}\right)$ and $\mathrm{D}_{0}\left(\mathrm{CH}_{3} \mathrm{CH}_{2}-\mathrm{SH}\right)$, i.e., $\approx 72-73 \mathrm{kcal} / \mathrm{mol}$. This, together with the excellent agreement observed between the experimental $\mathrm{D}_{0}\left(\mathrm{CH}_{3}-\mathrm{SH}\right)$ and the $\mathrm{G} 2$ prediction lends support to the G2/G2(MP3) prediction of $72.5 / 73.7 \mathrm{kcal} / \mathrm{mol}$ for $D_{0}(\mathrm{HS}-$ $\mathrm{CH}_{2} \mathrm{CH}_{2} \mathrm{SH}$ ). Using the latter value, we have constructed the Newton diagram for process (1) as shown in Fig. 2, where $v_{0}=1.65 \times 10^{5} \mathrm{~cm} / \mathrm{s}, v_{\text {lab }}$ and $v_{c . m}$ are the laboratory and centerof-mass velocities for the photofragments, and $\theta$ and $\theta_{c . m .}$ are the laboratory and center-ofmass angles, defined by the angles between the detector and molecular beam axis and between $v_{c . m}$. and the detector axis, respectively. The circles defined by $v_{c . m} .(\mathrm{SH})$ and $v_{\text {c.m. }}\left(\mathrm{CH}_{2} \mathrm{CH}_{2} \mathrm{SH}\right)$ are the maximum $\mathrm{v}_{\text {c.m. }}$ 's for $\mathrm{SH}$ and $\mathrm{CH}_{2} \mathrm{CH}_{2} \mathrm{SH}$ produced by process (1). Also shown in Fig. 2 are $\gamma$ and $\varepsilon$, which are defined as the angles between the laser electric field $\mathbf{E}$ and $\mathrm{v}_{\mathrm{c} . \mathrm{m} .}$ and between $\mathbf{E}$ and the detector axis, respectively.

The TOF spectra for HS obtained at $\theta_{\mathrm{lab}}=30^{\circ}, 45^{\circ}, 70^{\circ}$, and $90^{\circ}$ are depicted in Figs. 3(a), 3(b), 3(c), and 3(d), respectively. Although we conclude that the production of $2 \mathrm{CH}_{2} \mathrm{SH}$ and $\mathrm{H}+\mathrm{SCH}_{2} \mathrm{CH}_{2} \mathrm{SH}$ from the $193 \mathrm{~nm}$ photodissociation of $\mathrm{HSCH}_{2} \mathrm{CH}_{2} \mathrm{SH}$ is negligible, we cannot completely exclude the formation of these channels. The $\mathrm{D}_{0}$ value for a S-H bond $(\approx 86 \mathrm{kcal} / \mathrm{mol})$ (Refs. $12,26,28,41)$ is significantly higher than that for a C-S 


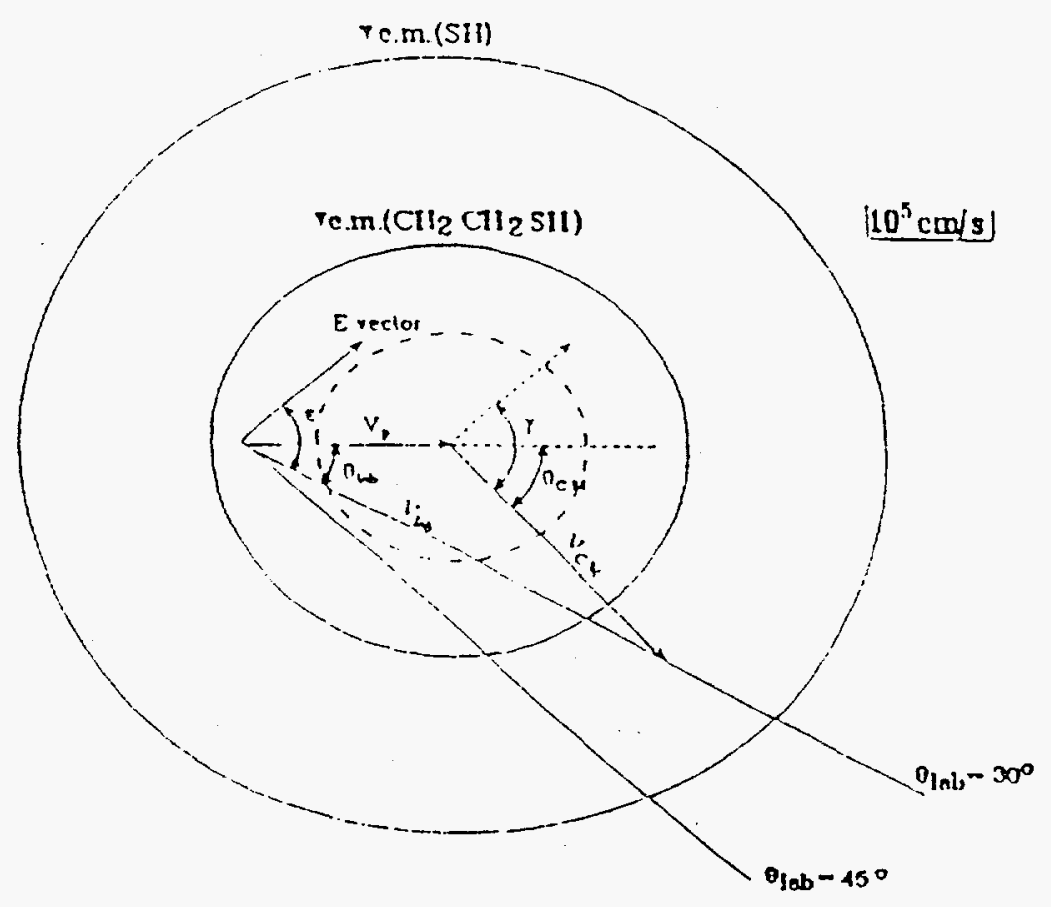

Figure 2. Kinematics for the formation of $\mathrm{HSCH}_{2} \mathrm{CH}_{2}+\mathrm{SH}$ by the $193 \mathrm{~nm}$ photodissociation of $\mathrm{HSCH}_{2} \mathrm{CH}_{2} \mathrm{SH} . \mathrm{v}_{0}\left(=1.65 \times 10^{5} \mathrm{~cm} / \mathrm{s}\right)$ is the laboratory veiocity for $\mathrm{HSCH}_{2} \mathrm{CH}_{2} \mathrm{SH}$. $\mathrm{v}_{\mathrm{c} . \mathrm{m}}(\mathrm{SH})$ and $\mathrm{v}_{\mathrm{c.m}}\left(\mathrm{CH}_{2} \mathrm{CH}_{2} \mathrm{SH}\right)$ are the maximum c.m. velocities for $\mathrm{SH}$ and $\mathrm{CH}_{2} \mathrm{CH}_{2} \mathrm{SH}$, respectively. The dashed circle define the maximum velocity for $\mathrm{SH}$ formed in the secondary dissociation of excited $\mathrm{CH}_{2} \mathrm{CH}_{2} \mathrm{SH}$ formed originally by process (1). The diagram shows the relationship $\gamma=\theta_{c . m}+\varepsilon-\theta_{1 a b}$, where $\gamma$ is the angie between the laser electric field (E) and the c.m. photofragment velocity; $\theta_{c m}$ is the angle between the molecular beam velocity and the fragment recoil c.m. velocity; $\varepsilon$ is the angle between $E$ and detector axis; and $\theta$ is the laboratory angle between the molecular beam and the detector axis. 


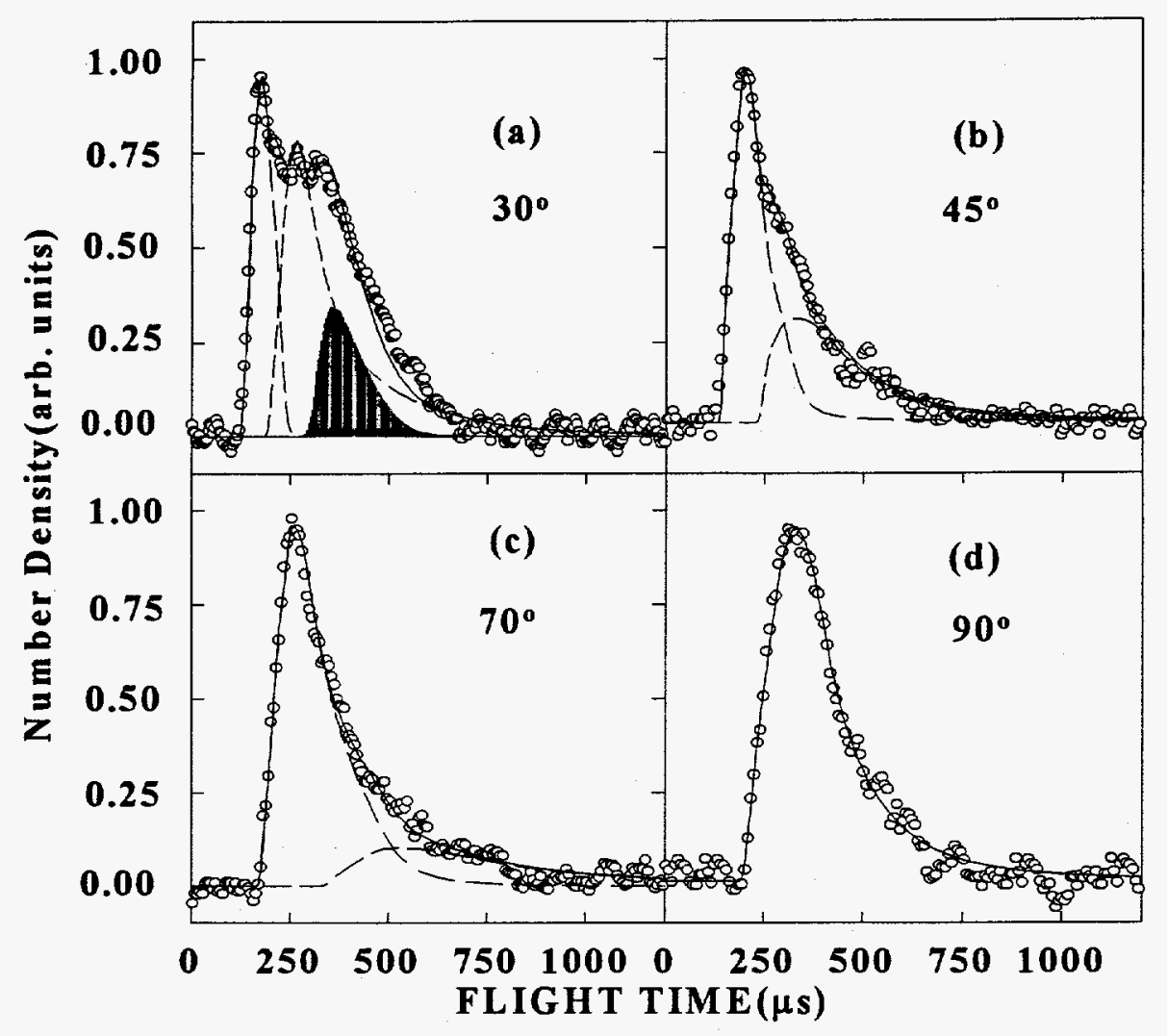

Figure 3. TOF spectra for $\mathrm{SH}$ measured at $\theta_{\mathrm{lab}}=$ (a) $30^{\circ}$, (b) $45^{\circ}$, (c) $70^{\circ}$, and (d) $90^{\circ}$. The dashed and dotted lines show the best fits due to $\mathrm{SH}$ and $\mathrm{CH}_{2} \mathrm{CH}_{2} \mathrm{SH}$, respectively, formed by process(1). The shaded peak is attributed to the secondary dissociation of internally excited $\mathrm{CH}_{2} \mathrm{CH}_{2} \mathrm{SH} \rightarrow \mathrm{CH}_{2} \mathrm{CH}_{2}+\mathrm{SH}$. The solid line is the sum of all these contributions. 
bond. The $\mathrm{G} 2$ calculations show that $\mathrm{D}_{0}\left(\mathrm{HSCH}_{2}-\mathrm{CH}_{2} \mathrm{SH}\right)=77.3 \mathrm{kcal} / \mathrm{mol}$ is also higher than $\mathrm{D}_{0}\left(\mathrm{HS}-\mathrm{CH}_{2} \mathrm{CH}_{2} \mathrm{SH}\right)$ by $4 \mathrm{kcal} / \mathrm{mol}$. Even if the formation of the $2 \mathrm{CH}_{2} \mathrm{SH}$ and $\mathrm{H}+$ $\mathrm{SCH}_{2} \mathrm{CH}_{2} \mathrm{SH}$ channels is finite, the $\mathrm{SH}^{+}$signals due to electron impact ionization of $\mathrm{CH}_{2} \mathrm{SH}$ and $\mathrm{SCH}_{2} \mathrm{CH}_{2} \mathrm{SH}$ would not affect the onset of process (1). Thus, the $\mathrm{E}_{\text {c.m. }}$ threshold for process (1) can be determined by direct transformation of TOF data near the onset of the spectra shown in Figs. 3(a)-3(d) into $E_{c . m}$ distributions, i.e., $P\left(E_{c . m}\right)$. This transformation reveals a relatively sharp onset at $E_{c . m}=75 \pm 1.5 \mathrm{kcal} / \mathrm{mol}$ for process (1). By energy conservation, we have the relationship

$\mathrm{E}(\mathrm{hv})+\mathrm{E}_{\mathrm{int}}\left(\mathrm{HSCH}_{2} \mathrm{CH}_{2} \mathrm{SH}\right)=\mathrm{D}_{0}\left(\mathrm{HS}-\mathrm{CH}_{2} \mathrm{CH}_{2} \mathrm{SH}\right)+\mathrm{E}_{\mathrm{c} . \mathrm{m} .}+\mathrm{E}_{\mathrm{int}}(\mathrm{SH})+\mathrm{E}_{\mathrm{int}}\left(\mathrm{CH}_{2} \mathrm{CH}_{2} \mathrm{SH}\right)(3)$

where $\mathrm{E}(\mathrm{hv}=193.3 \mathrm{~nm})=147.9 \mathrm{kcal}$ is the photon energy and $\mathrm{E}_{\mathrm{int}}\left(\mathrm{HSCH}_{2} \mathrm{CH}_{2} \mathrm{SH}\right)$, $\mathrm{E}_{\mathrm{inn}}(\mathrm{SH})$, and $\mathrm{E}_{\mathrm{int}}\left(\mathrm{CH}_{2} \mathrm{CH}_{2} \mathrm{SH}\right)$ represent the respective internal energies for $\mathrm{HSCH}_{2} \mathrm{CH}_{2} \mathrm{SH}$, $\mathrm{SH}$, and $\mathrm{CH}_{2} \mathrm{CH}_{2} \mathrm{SH}$. Assuming that $\mathrm{E}_{\text {int }}\left(\mathrm{HSCH}_{2} \mathrm{CH}_{2} \mathrm{SH}\right)$ is negligible because of the supersonic expansion, and that photofragments $\left(\mathrm{HS}+\mathrm{CH}_{2} \mathrm{CH}_{2} \mathrm{SH}\right)$ formed at $E_{\text {c.m. }}$ threshold of $75 \mathrm{kcal} / \mathrm{mol}$ contain no internal energies, $\mathrm{D}_{0}\left(\mathrm{HS}-\mathrm{CH}_{2} \mathrm{CH}_{2} \mathrm{SH}\right)$ is calculated to be $72.9 \pm 1.5 \mathrm{kcal} / \mathrm{mol}$. Under the supersonic expansion conditions used in this experiment, the rotational relaxation for $\mathrm{HSCH}_{2} \mathrm{CH}_{2} \mathrm{SH}$ is expected to be efficient. However, the vibrational relaxation for $\mathrm{HSCH}_{2} \mathrm{CH}_{2} \mathrm{SH}$ is most likely incomplete. Using the calculated $\mathrm{HF} / 6-31 \mathrm{G}(\mathrm{d})$ vibrational frequencies for $\mathrm{HSCH}_{2} \mathrm{CH}_{2} \mathrm{SH}$, we estimate that the vibrational energy for $\mathrm{HSCH}_{2} \mathrm{CH}_{2} \mathrm{SH}$ is $\approx 2.8 \mathrm{kcal} / \mathrm{mol}$ at $330 \mathrm{~K}$. The vibrational excitation 
of $\mathrm{HSCH}_{2} \mathrm{CH}_{2} \mathrm{SH}$ has the effect of shifting the onset to higher $\mathrm{E}_{\mathrm{c} . \mathrm{m}}$, which in turn yields a lower value for $\mathrm{D}_{0}\left(\mathrm{HS}-\mathrm{CH}_{2} \mathrm{CH}_{2} \mathrm{SH}\right)$. Without detailed experimental characterization of the $\mathrm{HSCH}_{2} \mathrm{CH}_{2} \mathrm{SH}$ beam, we assume that $\mathrm{HSCH}_{2} \mathrm{CH}_{2} \mathrm{SH}$ is cooled to a vibrational temperature of $\approx 150 \mathrm{~K}$ after the supersonic expansion. To take into account this possible vibrational hot band effect, we recommend a value of $74 \pm 2 \mathrm{kcal} / \mathrm{mol}$ for $\mathrm{D}_{0}\left(\mathrm{HS}-\mathrm{CH}_{2} \mathrm{CH}_{2} \mathrm{SH}\right)$. As expected, this latter value is close to the experimental $\mathrm{D}_{0}$ values for $\mathrm{CH}_{3}-\mathrm{SH}$ and $\mathrm{CH}_{3} \mathrm{CH}_{2}-$ $\mathrm{SH}$ and is in good agreement with the theoretical prediction of $72.5 \mathrm{kcal} / \mathrm{mol}$ (see Table II).

In a previous $\mathrm{G} 2$ study of the $\mathrm{C}_{2} \mathrm{H}_{5} \mathrm{~S}$ isomers, $\mathrm{CH}_{3} \mathrm{CH}_{2} \mathrm{~S}$, cis- $\mathrm{CH}_{3} \mathrm{CHSH}$, trans$\mathrm{CH}_{3} \mathrm{CHSH}$, and $\mathrm{CH}_{3} \mathrm{SCH}_{2}$ were found to be stable with $\Delta_{\mathrm{f}} \mathrm{H}_{0}$ values of $27.5,35.3,35.6$, and $37.3 \mathrm{kcal} / \mathrm{mol}$, respectively. ${ }^{18}$ The $\mathrm{G} 2$ calculations indicates that these isomers are more stable than cis- and trans- $\mathrm{CH}_{2} \mathrm{CH}_{2} \mathrm{SH}$, which have the respective $\Delta_{\mathrm{f}} \mathrm{H}_{0}{ }^{\circ}(\mathrm{G} 2)$ values for $\mathrm{CH}_{3} \mathrm{CH}_{2} \mathrm{~S}\left(31.4 \pm 2 \mathrm{kcal} / \mathrm{mol}\right.$ ) (Ref. 12) and $\mathrm{CH}_{3} \mathrm{SCH}_{2}(34.8 \pm 2.5 \mathrm{kcal} / \mathrm{mol})(\mathrm{Ref} .10)$ determined in $193 \mathrm{~nm}$ laser photofragmentation TOF mass spectrometric experiments are in reasonable agreement with the corresponding $\mathrm{G} 2$ predictions. A value of $35.2 \pm 1.6$ $\mathrm{kcal} / \mathrm{mol}$ for $\Delta_{\mathrm{f}} \mathrm{H}_{0}{ }^{\circ}\left(\mathrm{CH}_{3} \mathrm{SCH}_{2}\right)$ has also been obtained in a recent kinetic study. ${ }^{42}$ These values are included in Table II for comparison with the $\mathrm{G} 2 \Delta_{\mathrm{f}} \mathrm{H}_{0}{ }^{\circ}\left(\mathrm{CH}_{2} \mathrm{CH}_{2} \mathrm{SH}\right)$ value. However, an experimental value for $\Delta_{\mathrm{f}} \mathrm{H}_{0}{ }^{\circ}\left(\mathrm{CH}_{2} \mathrm{CH}_{2} \mathrm{SH}\right)$ cannot be obtained because the experimental $\Delta_{\mathrm{f}} \mathrm{H}_{0}{ }^{\circ}\left(\mathrm{HSCH}_{2} \mathrm{CH}_{2} \mathrm{SH}\right)$ is unknown. The fact that the experimental and G2/G2(MP3) theoretical $\mathrm{D}_{0}\left(\mathrm{HS}-\mathrm{CH}_{2} \mathrm{CH}_{2} \mathrm{SH}\right)$ are in agreement supports the conclusion that the $\mathrm{C}_{2} \mathrm{H}_{5} \mathrm{~S}$ radical formed in the $193 \mathrm{~nm}$ photodissociation of $\mathrm{HSCH}_{2} \mathrm{CH}_{2} \mathrm{SH}$ has the 
$\mathrm{CH}_{2} \mathrm{CH}_{2} \mathrm{SH}$ structure. This conclusion is consistent with the previous observation that breakage of the $\mathrm{C}-\mathrm{S}$ bonds in $\mathrm{CH}_{3} \mathrm{SCH}_{3},{ }^{12} \mathrm{CH}_{3} \mathrm{CH}_{2} \mathrm{SCH}_{2} \mathrm{CH}_{3},{ }^{18}$ and $\mathrm{CH}_{3} \mathrm{SSCH}_{3}$ (Ref. 9) induced by the absorption of a $193 \mathrm{~nm}$ photon are prompt, yielding the photoproduct without atomic rearrangement, i.e., forming $\mathrm{CH}_{3} \mathrm{~S}+\mathrm{CH}_{3}, \mathrm{CH}_{3} \mathrm{CH}_{2} \mathrm{~S}+\mathrm{CH}_{2} \mathrm{CH}_{3}$, and $\mathrm{CH}_{3}$ $+\mathrm{SSCH}_{3}$, respectively.

The TOF spectrum for $\mathrm{SH}$ observed at $30^{\circ}$ reveals three peaks[Fig. 3(a)]. The fastest and most intense peak is attributable to SH formed by process (1) (dashed curve), while the second peak can be fitted by the corresponding fragment $\mathrm{CH}_{2} \mathrm{CH}_{2} \mathrm{SH}$ (dotted curve). That is, the $\mathrm{SH}^{+}$signal observed for the second peak is formed by the electron impact dissociative ionization process (2). The shaded peak can accounted for by the secondary dissociation of internally excited $\mathrm{CH}_{2} \mathrm{CH}_{2} \mathrm{SH}$. Using the $\mathrm{G} 2$ values of $\Delta_{\mathrm{f}} \mathrm{H}_{0}{ }^{\circ}\left(\mathrm{CH}_{2} \mathrm{CH}_{2}\right)=14.7 \mathrm{kcal} / \mathrm{mol}$ and $\Delta_{\mathrm{f}} \mathrm{H}_{0}{ }^{\circ}(\mathrm{SH})=34.4 \mathrm{kcal} / \mathrm{mol}$ and the G2(MP3) $\Delta_{\mathrm{f}} \mathrm{H}_{0}{ }^{\circ}(c i s-$ $\left.\mathrm{CH}_{2} \mathrm{CH}_{2} \mathrm{SH}\right)=41.5 \mathrm{kcal} / \mathrm{mol}$ obtained here, the dissociation process,

$$
\mathrm{CH}_{2} \mathrm{CH}_{2} \mathrm{SH} \rightarrow \mathrm{CH}_{2} \mathrm{CH}_{2}+\mathrm{SH}
$$

is predicted to be endothermic by only $7.6 \mathrm{kcal} / \mathrm{mol}$. The maximum velocity for $\mathrm{SH}$ formed by process (4) is also shown by the dashed circle in the Newton diagram of Fig. 2. Due to the kinematic constraints of the primary $\mathrm{CH}_{2} \mathrm{CH}_{2} \mathrm{SH}$ radicals, the TOF distribution for the secondary SH radicals is slow and broad, as shown by the shaded curve in Fig. 3(a). The $P\left(E_{c . m}\right)$ of the secondary dissociation process (4) is found to decrease nearly exponentially 
toward higher $\mathrm{E}_{\mathrm{c.m}}$ (low internal excitation), in accordance with that expected for a statistical unimolecular dissociation process. ${ }^{33}$ The contributions to the TOF spectra observed at $\theta_{\mathrm{lab}}=45^{\circ}, 70^{\circ}$, and $90^{\circ}$ due to the secondary dissociation of $\mathrm{CH}_{2} \mathrm{CH}_{2} \mathrm{SH}[$ process(3)] are negligible.

The $P\left(E_{\text {c.m. }}\right)$ for process (1) shown in Fig. 4 represents the best fit of the TOF spectra for SH observed at $\theta_{\mathrm{lab}}=30^{\circ}, 45^{\circ}, 70^{\circ}$, and $90^{\circ}$. This $\mathrm{P}\left(\mathrm{E}_{\mathrm{c} . \mathrm{m}}\right)$ of process (1) has a maximum at $E_{c . m} \approx 30 \mathrm{kcal} / \mathrm{mol}$. Due to the kinematic constraint, the $\mathrm{P}\left(\mathrm{E}_{\mathrm{c} . \mathrm{m}}\right)$ at $\mathrm{E}_{\mathrm{c} . \mathrm{m}}<9$ $\mathrm{kcal} / \mathrm{mol}$ cannot be probed at $\theta_{\mathrm{lab}} \geq 30^{\circ}$. The $\mathrm{P}\left(\mathrm{E}_{\mathrm{c.m}}\right)$ of Fig. $3(\mathrm{~b})$ is zero at $\mathrm{E}_{\mathrm{c} . \mathrm{m}}<10$ $\mathrm{kcal} / \mathrm{mol}$. However, this portion of the $\mathrm{P}\left(\mathrm{E}_{\mathrm{c.m}}\right)$ has no effect on the fit of the TOF spectra measured at $\theta>30^{\circ}$. It is most likely that the $P\left(E_{c . m}\right)$ at $E_{c . m}<10 \mathrm{kcal} / \mathrm{mol}$ is small, but finite.

The formation of $\mathrm{CH}_{2} \mathrm{CH}_{2} \mathrm{SH}$ in the $193 \mathrm{~nm}$ photodissociation of $\mathrm{HSCH}_{2} \mathrm{CH}_{2} \mathrm{SH}$ observed here is consistent with the conclusion that the dissociation involves a repulsive potential surface associated with the C-S bond, which is formed by direct photoexcitation and/or by rapid intramolecular access followed by photoexcitation. The $\mathrm{P}\left(\mathrm{E}_{\mathrm{c.m}}\right)$ for process (1) is similar to that observed for the formation of $\mathrm{CH}_{3} \mathrm{CH}_{2}+\mathrm{SH}$ in the $193 \mathrm{~nm}$ photodissociation of $\mathrm{CH}_{3} \mathrm{CH}_{2} \mathrm{SH}$. The prompt dissociation from a repulsive surface would not allow atomic rearrangement of the photofragments. Since photoexcitation involves a vertical transition, the initial geometry formed on the excited surface should be similar to the $\mathrm{HSCH}_{2} \mathrm{CH}_{2} \mathrm{SH}\left(\mathrm{C}_{2 \mathrm{~h}}\right)$ structure. The similarity of the structure for $\mathrm{CH}_{2} \mathrm{CH}_{2} \mathrm{SH}$, especially for trans- $\mathrm{CH}_{2} \mathrm{CH}_{2} \mathrm{SH}$, to that of $\mathrm{HSCH}_{2} \mathrm{CH}_{2} \mathrm{SH}$ (Fig. 1) is consistent with the prompt $\mathrm{C}-\mathrm{S}$ bond cleavage mechanism. The main relaxation step to produce the stable 


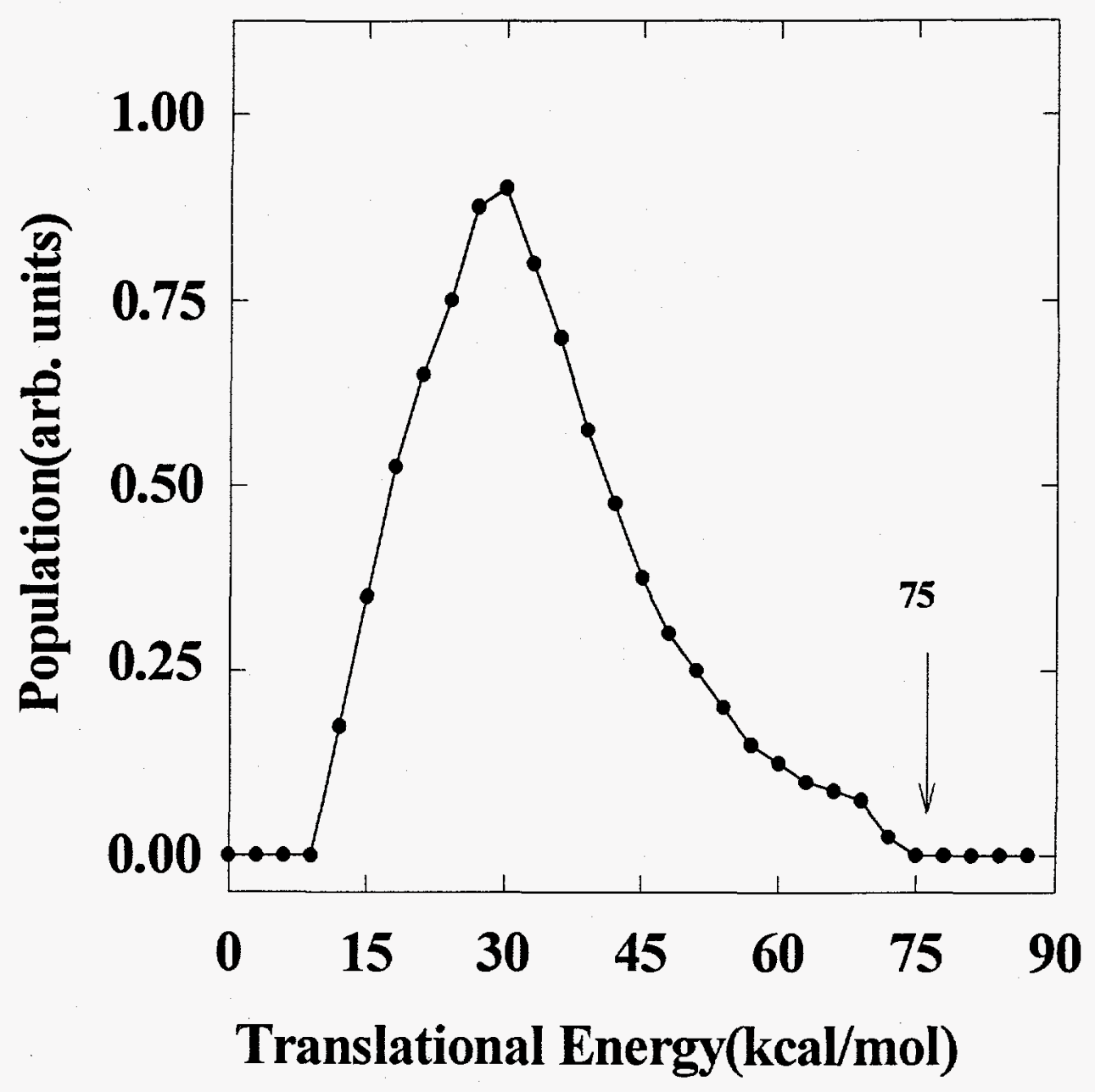

Figure 4. The $P\left(E_{c . m}\right)$ distribution obtained by the forward simulation procedure, which gives the best fit for all the TOF spectra of Fig. 3 . 
$\mathrm{CH}_{2} \mathrm{CH}_{2} \mathrm{SH}$ radical followed by the $\mathrm{C}-\mathrm{S}$ bond cleavage involves the rehybridization of the terminal carbon atom from $\mathrm{sp}^{3}$ to $\mathrm{sp}^{2}$.

Considering the photon energy of $6.43 \mathrm{eV}(193 \mathrm{~nm})$ used in this experiment and the accuracy $(\approx 0.5 \mathrm{eV})$ of the FOCI calculations, the possible excited states involved in process (1) are $1^{1} \mathrm{~A}_{\mathrm{u}}, 1^{1} \mathrm{~B}_{\mathrm{g}}$, and $2^{1} \mathrm{~B}_{\mathrm{g}}$ with vertical excitation energies of 5.9, 6.0, and 6.8 $\mathrm{eV}$, respectively. However, the transitions $\mathrm{X}^{1} \mathrm{~A}_{\mathrm{g}} \rightarrow 1{ }^{1} \mathrm{~B}_{\mathrm{g}}$ and $\mathrm{X}^{1} \mathrm{~A}_{\mathrm{g}} \rightarrow 2{ }^{1} \mathrm{~B}_{\mathrm{g}}$ are dipoleforbidden processes. Thus, the $1{ }^{1} \mathrm{~A}_{\mathrm{g}}$ state is mostly likely the excited state responsible for the $193 \mathrm{~nm}$ photodissociation of $\mathrm{HSCH}_{2} \mathrm{CH}_{2} \mathrm{SH}$. Since the major electronic configuration for the $\mathrm{HSCH}_{2} \mathrm{CH}_{2} \mathrm{SH}\left(1{ }^{1} \mathrm{~A}_{u}\right)$ is ...( $\left(9 \mathrm{~b}_{u} 10 \mathrm{a}_{\mathrm{g}} 3 \mathrm{~b}_{\mathrm{g}}\right)^{2}\left(3 \mathrm{a}_{u} l \mathrm{a}_{\mathrm{g}}\right)^{1}$, the $\mathrm{X}{ }^{1} \mathrm{~A}_{\mathrm{g}} \rightarrow{ }^{1} \mathrm{~A}_{u}$ transition corresponds to a $n \rightarrow \sigma^{*}$ transition, and the potential energy surface is probably repulsive along the stretching of the $\mathrm{C}-\mathrm{S}$ bond, leading to prompt $\mathrm{C}-\mathrm{S}$ bond cleavage. This is consistent with the conclusion inferred from the experimental observation. We note that the $1{ }^{1} \mathrm{~A}_{u}$ state may interact with other excited states with the same symmetry, such as 2 ${ }^{1} \mathrm{~A}_{u}$, along the dissociation coordinates, Such an interaction which results in an avoided crossing has been found in the theoretical studies of other organosulfur systems. ${ }^{24,25,43}$ Since the $\angle(\mathrm{H}-\mathrm{S}-\mathrm{C})$ in $\mathrm{HSCH}_{2} \mathrm{CH}_{2} \mathrm{SH}$ is predicted to be $97.5^{\circ}$, the $\mathrm{SH}$ fragments produced by process (1) are expected to be in high rotationally excited states. The accompanying $\mathrm{CH}_{2} \mathrm{CH}_{2} \mathrm{SH}$ fragment should be excited rotationally as well as vibrationally. As shown in the $P\left(E_{c . m}\right)$ of Fig. 4, the most probable $E_{c . m}\left[\left(E_{c . m}\right)_{m p}\right]$ for the formation of SH $+\mathrm{CH}_{2} \mathrm{CH}_{2} \mathrm{SH}$ is $\approx 30 \mathrm{kcal} / \mathrm{mol}$, which is $\approx 40 \%$ of the available energy of $74 \mathrm{kcal} / \mathrm{mol}$. The corresponding most probable internal excitation $\left[\left(\mathrm{E}_{\mathrm{int}}\right)_{\mathrm{mp}}\right]$ for the photoproducts is $\approx 44$ 
$\mathrm{kcal} / \mathrm{mol}\left(\approx 60 \%\right.$ of the available energy). Table II compares the partitions of $\left(\mathrm{E}_{\mathrm{c.m}}\right)_{\mathrm{mp}}$ and $\left(\mathrm{E}_{\text {int }}\right)_{\mathrm{mp}}$ for the $\mathrm{C}-\mathrm{S}$ scission process observed in the $193 \mathrm{~nm}$ photodissociation of $\mathrm{CH}_{3} \mathrm{SH}$, ${ }^{11,23} \mathrm{CH}_{3} \mathrm{CH}_{2} \mathrm{SH},{ }^{12}$ and $\mathrm{HSCH}_{2} \mathrm{CH}_{2} \mathrm{SH}$. The trend of increasing $\left(\mathrm{E}_{\mathrm{int}}\right)_{\mathrm{mp}}$ observed as the precursor molecule is changed from $\mathrm{CH}_{3} \mathrm{SH}$ to $\mathrm{CH}_{3} \mathrm{CH}_{2} \mathrm{SH}$ to $\mathrm{HSCH}_{2} \mathrm{CH}_{2} \mathrm{SH}$ can simply be attributed to the increasing complexity of the molecule with greater internal degrees of freedom.

The angular distribution of the photofragments has the form ${ }^{44}$

$$
P(\gamma)=(1 / 4 \pi)\left[1+\beta P_{2}(\cos \gamma)\right]
$$

where $P_{2}(\cos \gamma)$ is the second Legendre polynomial and $\beta$ is the anisotropy parameter. Figure 5 shows the angular distribution for process (1) obtained by integration of the contribution of SH formed by process (1) to the measured TOF spectra at $\theta_{\mathrm{lab}}=45^{\circ}$. The fitting (solid curve) of the measured (solid dots) angular distribution using Eq. (5) yields $\beta=-0.4 \pm 0.1$ for process (1). For an instaneous photodissociation process whose kinetic energy of dissociation is very large compared to the energy of rotation, $\beta$ can be expressed by the simple equation, $\beta=3 \cos ^{2} \vartheta-1,{ }^{44}$ where $\vartheta$ is the angle between the recoil velocity of the fragment and the transition dipole moment. Hence, in the case of $\beta=-0.4, \vartheta$ corresponds to $63.4^{\circ}$.

The observed $\beta$ value and $P(\gamma)$ can be rationalized by symmetry arguments and results of the FOCI calculations. When the z-axis is taken as the molecular twofold axis in the $C_{2 h}$ point group, the $x-, y-$, and $z$-axes transform as the $B_{u}, B_{u}$, and $A_{u}$ irreducible representations, respectively. Hence, the $\mathrm{x}$ - and y-components of the $\mathrm{X}^{1} \mathrm{~A}_{\mathrm{g}} \rightarrow 1^{1} \mathrm{~A}_{w}$ 


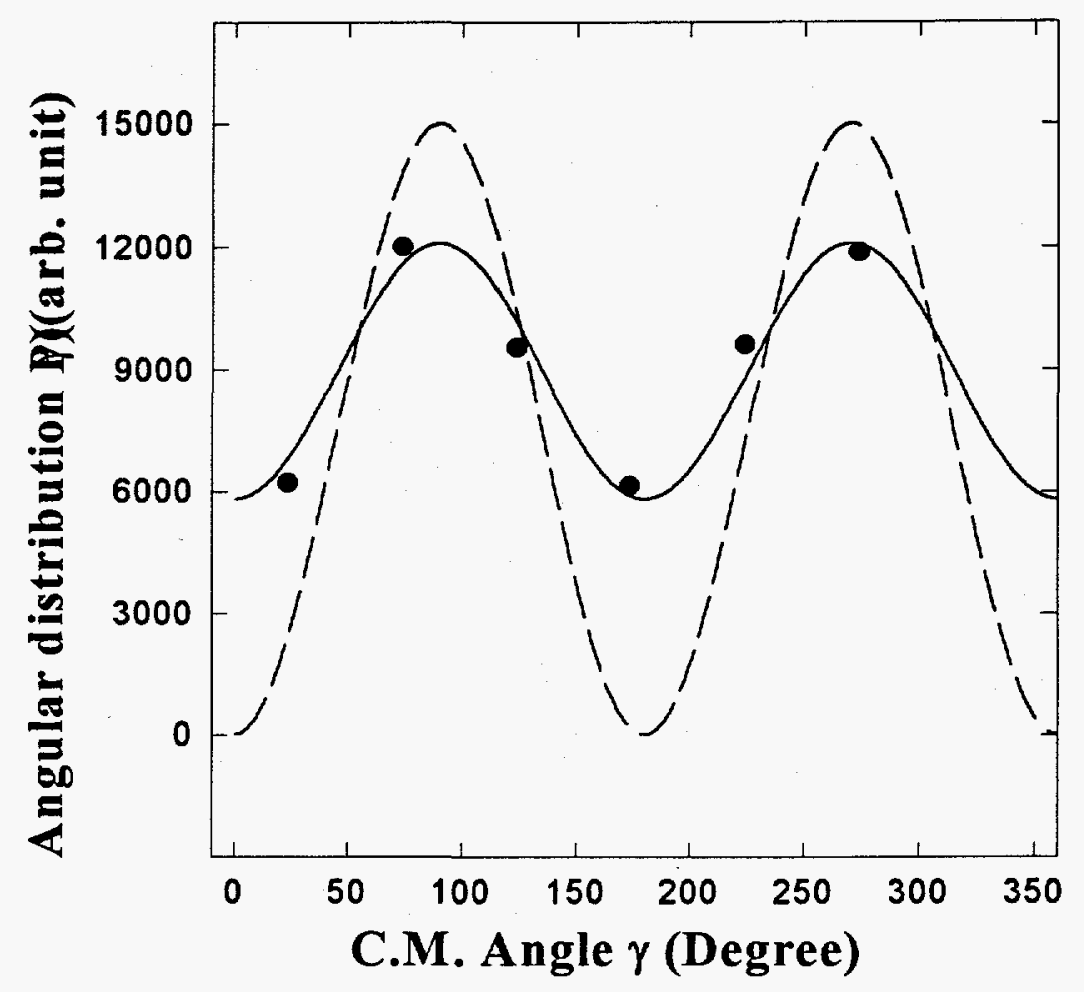

Figure 5. Angular distribution. $\mathrm{P}(\gamma)$, for channel (1) measured at $\theta_{\mathrm{lab}}=45^{\circ}$. The solid dots are experimental results and the solid curve represents the best fit using Eq. (4) with $\beta=-0.4 \pm 0.1$. $\gamma$ is the angle between the laser electric field (E) and the c.m. fragment velocity. The dotted curve corresponds to $\beta=-1$ for an instantaneous photodissociation process (see the text). 
transition moment vanish. That is, the transition moment for the $X{ }^{1} \mathrm{~A}_{\mathrm{g}} \rightarrow 1{ }^{1} \mathrm{~A}_{\mathrm{u}}$ excitation must coincide with the z-axis. Since the carbon and sulfur atoms of $\mathrm{HSCH}_{2} \mathrm{CH}_{2} \mathrm{SH}$ lie on the $\sigma_{\mathrm{h}}$-plane, the transition moment for the $\mathrm{X}^{1} \mathrm{~A}_{\mathrm{g}} \rightarrow 1{ }^{1} \mathrm{~A}_{\mathrm{u}}$ excitation is perpendicular to the C-S bonds. For an instantaneous photodissociation process, we expect $\gamma=90^{\circ}$ and $\beta=-1$.

The angular distribution for $\beta=-1$ is shown as the dotted curve in Fig. 5 . The less anisotropic distribution measured experimentally could result from either moderate rotational smearing or a distortion of the molecular frame in the excited state. Furthermore, the finite involvement of less stable conformers of both $\mathrm{HSCH}_{2} \mathrm{CH}_{2} \mathrm{SH}$ and $\mathrm{CH}_{2} \mathrm{CH}_{2} \mathrm{SH}$ in the photodissociation process may also contribute to the less anisotropic angular distribution for process (1) observed in this experiment. Nevertheless, we may conclude that the experimental $\beta$ value of -0.4 for process (1) is in qualitative agreement with the prediction of FOCI calculations and symmetry arguments that the C-S bond scission in the $193 \mathrm{~nm}$ photodissociation of $\mathrm{HSCH}_{2} \mathrm{CH}_{2} \mathrm{SH}$ is fast compared to molecular rotation.

\section{Conclusion}

The product channels resulting from the $193 \mathrm{~nm}$ photofragmentation of $\mathrm{HSCH}_{2} \mathrm{CH}_{2} \mathrm{SH}$ have been investigated by the TOF mass spectrometric technique. Similar to the observation of the $193 \mathrm{~nm}$ photofragmentation of $\mathrm{CH}_{3} \mathrm{CH}_{2} \mathrm{SH}$, the C-S scission to yield $\mathrm{SH}+\mathrm{CH}_{2} \mathrm{CH}_{2} \mathrm{SH}$ constitutes the overwhelmingly dominant product channel. Within the sensitivity of the present experiment, the formation of $\mathrm{H}+\mathrm{SCH}_{2} \mathrm{CH}_{2} \mathrm{SH}$ and $2 \mathrm{CH}_{2} \mathrm{SH}$ are not found, indicating that the dissociation channels involving $\mathrm{S}-\mathrm{H}$ and $\mathrm{C}-\mathrm{C}$ bond cleavages are not important. On the basis of the $E_{c . m}$ threshold for the $P\left(E_{c . m}\right)$ distribution 
of process(1), we obtain a value of $74 \pm 2 \mathrm{kcal} / \mathrm{mol}$ for $\mathrm{D}_{0}\left(\mathrm{HS}-\mathrm{CH}_{2} \mathrm{CH}_{2} \mathrm{SH}\right)$. The translational energy distribution for photofragments of channel (1) is found to peak at $E_{c . m}$ $\approx 30 \mathrm{kcal} / \mathrm{mol}$. The $\mathrm{D}_{0}$ values for $\mathrm{HS}-\mathrm{CH}_{2} \mathrm{CH}_{2} \mathrm{SH}, \mathrm{CH}_{3}-\mathrm{SH}$, and $\mathrm{CH}_{3} \mathrm{CH}_{2}-\mathrm{SH}$ are identical within the experimental uncertainties. This observation is consistent with the interpretation that the $\sigma$-bonding involved in the C-S bonds of these molecules is localized. The angular distribution measurements of SH gives $\beta=-0.4 \pm 0.1$ for process (1), indicating that the C-S bond fission is fast with respect to molecular rotation.

The structure and energetics for $\mathrm{CH}_{2} \mathrm{CH}_{2} \mathrm{SH}$ and $\mathrm{HSCH}_{2} \mathrm{CH}_{2} \mathrm{SH}$ have been investigated at G2/G2(MP3) level of theory. The predictions for $D_{0}(H S-$ $\left.\mathrm{CH}_{2} \mathrm{CH}_{2} \mathrm{SH}\right)=72.5 / 73.7 \mathrm{kcal} / \mathrm{mol}$ are in excellent agreement with the experimental result. This observation supports that the $\mathrm{C}_{2} \mathrm{H}_{5} \mathrm{~S}$ isomer formed in the $193 \mathrm{~nm}$ photodissociation of $\mathrm{HSCH}_{2} \mathrm{CH}_{2} \mathrm{SH}$ has the $\mathrm{CH}_{2} \mathrm{CH}_{2} \mathrm{SH}$ structure.

The FOCI calculations suggest that an $\mathrm{n} \rightarrow \sigma^{*}$ transition is involved for process (1), resulting in a repulsive surface $\left({ }^{1} \mathrm{~A}_{\mathrm{u}}\right)$ with mostly antibonding character for the C-S bonds. Furthermore, the transition moment for the $X{ }^{1} A_{g} \rightarrow 1{ }^{1} A_{u}$ excitation is perpendicular to the C-S bonds, resulting in anisotropic angular distribution in qualitative agreement with experimental observation.

\section{References}

(1) T. E. Graedel, Rev. Geophys., Space Phys. 15, 421(1977).

(2) S. W. Benson, Chem. Rev. 78, 23(1978).

(3) W. E. Burnett, Environ. Sci. Technol. 8, 744(1969). 
(4) M. D. Bentley, I. B. Douglass, J. A. Lacadie, and D. R. Whittier, J. Air Pollution Control Assoc. 22, 744(1969).

(5) J. G. Calvert and J. N. Pitts, Jr. Photochemistry (Wiley, New York, 1966).

(6) S. D. Thompson, D. G. Carroll, F. Watson, M. O'Donnell, and S.P.McGlynn, J. Chem. Phys. 45, 1367(1966).

(7) P. M. Rao and A. R. Knight, Can. J. Chem. 46, 2462 (1968).

(8) W.-B. Tzeng, H.-M. Yin, W.-Y Leung, J.-Y. Luo, S.Nourbakhsh, G. D. Flesch, and C. Y. Ng, J. Chem. Phys. 88, 1658(1988).

(9) S. Nourbakhsh, C.-L. Liao, and C. Y. Ng, J. Chem. Phys. 92, 6587(1990).

(10) S. Nourbakhsh, K. Norwood, H.-M. Yin, C.-L Liao, and C.Y. Ng, J. Chem. Phys. 95, $5014(1991)$.

(11) S. Nourbakhsh, K. Norwood, H.-M. Yin, C.-L. Liao, and C. Y. Ng, J. Chem. Phys. 95, 946(1991).

(12) S. Nourbakhsh, H.-M. Yin, C.-L. Liao, and C. Y. Ng, Chem. Phys. Lett. 183, $348(1991)$.

(13) S. Nourbakhsh, K. Norwood, G.-Z. He, and C. Y. Ng, J. Am. Chem. Soc. 113, $6311(1991)$.

(14) S. Nourbakhsh, H.-M. Yin, C.-L. Liao, and C. Y. Ng, Chem. Phys. Lett. 190, 469(1992).

(15) K. Norwood, S. Nourbakhsh, G.-Z. He, and C. Y. Ng, Chem. Phys. Lett. 184, 147(1991). 
(16) C.-W Hsu, C.-L Liao, Z.-X. Ma, P. J. H. Tjossem, and C. Y. Ng, J. Chem. Phys. 97, 6283(1992).

(17) C.-W. Hsu, C.-L. Liao, Z.-X. Ma, P. J. H. Tjossem, and C. Y. Ng, Chem. Phys. Lett. 199, 78(1992).

(18) Z.-X. Ma, C.-L. Liao, H.-M. Yin, C. Y. Ng, S.-W. Chiu, I. Ma, and W.-K. Li, Chem. Phys. Lett. 213, 250(1993).

(19) Z.-X. Ma, C.-L. Liao, C. Y. Ng, Y.-S. Cheung, W.-K. Li, and T. Baer, J. Chem. Phys. 100, 4780(1994).

(20) C.-W. Hsu, D.P. Baldwin, C.-L. Liao, and C.Y. Ng, J. Chem. Phys. 100, 8047(1994).

(21) C.W. Hsu and C. Y. Ng, J. Chem. Phys. 101, 5596(1994).

(22) C.-W. Hsu, C.-L. Liao, Z.-X. Ma, and C.Y. Ng, J. Phys. Chem. 99, 1760(1995).

(23) J.S.Keller, P. W. Kash, E. Jensen, and J. L. Butler, J. Chem. Phys. 96, 4324(1992).

(24) E. Jensen, J. S. Keller, G.C.G. Waschewsky, J. E. Stevens, R. L. Graham, K. F. Freed, and L. J. Butler, J. Chem. Phys. 98, 2882(1993).

(25) J. E. Steven, H. W. Jang, L. J. Butler, and J. C. Light, J. Chem. Phys. 102, 7059(1995).

(26) J. Segall, Y. Wen, R. Singer, M. Dulligan, and C. Wittig, J. Chem. Phys. 99, $6600(1993)$.

(27) S. H. S. Wilson, M. N. R. Ashfold, and R. N. Dixson, Chem. Phys. Lett. 222, 457(1994).

(28) S. H. S. Wilson, M. N. R. Ashold, and R. N. Dixon, J. Chem. Phys. 101, 7538(1994). 
(29) J. Baker and J. M. Dyke, Chem. Phys. Lett. 213, 257(1993).

(30) L. A. Curtiss, K. Raghavachari, G. W. Trucks, and J. A. Pople, J. Chem. Phys. 94, 7221(1991).

(31) L. A. Curtiss, K. Raghavachari, and J. A. Pople, J. Chem. Phys. 98, 1293(1993).

(32) M. W. Schmidt, K. K. Baldridge, J. A. Boatz, J. H. Jensen, S. Koseki, M. S. Gordon, K. A. Nguyen, T. L. Windus, and T. S. Elbert, QCPE Bull, 10, 52(1990).

(33) T. K. Minton, G. M. Nathanson, and Y.T. Lee, J. Chem. Phys. 86, 1991(1987).

(34) E. J. Hintsa, X. Zhao, and Y. T. Lee, J. Chem. Phys. 92, 2280(1990).

(35) X. Zhao, Ph.D. thesis, University of California, Berkeley, CA, 1988.

(36) L. J. Butler, E. J. Hintsa, S. F. Shane, and Y. T. Lee, J. Chem. Phys. 86, 2051(1987).

(37) M. J. Frisch et al., GAUSSIAN 90, Gaussian, Pittsburgh, Pennsylvania, 1990; M. J. Frisch et. al. GAUSSIAN 92, Revision C, Gaussian, Pittsburgh, Pennsylvania. 1992.

(38) S.-W. Chiu, W.-K Li, W.-B. Tzeng, and C. Y. Ng, J. Chem. Phys. 97, 6557(1992).

(39) S. G. Lias, J. E. Bartmess, J. F. Liebman, J.L. Holmes, R. D. Levin, and W. G. Mallard. J. Phys. Chem. Ref. Data 17, Suppl. No. 1(1988).

(40) L. A. Curtiss, K. Raghavchari, and J. A. Pople, J. Chem. Phys. 93, 2537(1990).

(41) J. M. Nichovich, K. D. Kreutter, C. A. can Dijk, and P. H. Wine, J. Phys. Chem. 96 2518(1992).

(42) P. H. Wine(private communication).

(43) C.-W-Hsu, C.-L. Liao, Z.-X. Ma, and C.Y. Ng, J. Phys. Chem. 99, 1760(1995).

(44) S.-C. Yang and R. Bersohn, J. Chem. Phys. 61, 4400(1974). 


\title{
THIOPHENE BIRADICAL DECAY OF THE PRIMARY LASER
}

PHOTOFRAGMENTATION PRODUCT AT 193 NM

A paper to be submitted to the Journal of Chemical Physics

$$
\text { H.-Q. Zhao and C. Y. Ng }
$$

\begin{abstract}
Thiophene biradical decay dynamics as the primary laser photofragmentation product at $193 \mathrm{~nm}$ has been studied. Five product processes are identified as follows:
\end{abstract}

$$
\begin{aligned}
& \mathrm{C}_{4} \mathrm{H}_{4} \mathrm{~S} \text { (Thiophene) } \rightarrow \mathrm{HC} \equiv \mathrm{CH}+\mathrm{C}_{2} \mathrm{H}_{2} \mathrm{~S} \\
& \mathrm{C}_{4} \mathrm{H}_{4} \mathrm{~S} \text { (Thiophene) } \rightarrow \mathrm{S}+\mathrm{C}_{4} \mathrm{H}_{4} \\
& \mathrm{C}_{4} \mathrm{H}_{4} \mathrm{~S} \text { (Thiophene) } \rightarrow \mathrm{C}_{3} \mathrm{H}_{3}+\mathrm{HCS} \\
& \mathrm{C}_{4} \mathrm{H}_{4} \mathrm{~S} \text { (Thiophene) } \rightarrow \mathrm{CS}+\mathrm{C}_{3} \mathrm{H}_{4} \\
& \mathrm{C}_{4} \mathrm{H}_{4} \mathrm{~S} \text { (Thiophene) } \rightarrow \mathrm{SH}+\mathrm{C}_{4} \mathrm{H}_{3}
\end{aligned}
$$

The derived $\mathbf{P}\left(E_{c . m}\right)$ for these processes show characteristics of unimolecular decay. For process (1), two isomer products: $\bullet \mathrm{CHCHS} \bullet$ and $c-\mathrm{CH}=\mathrm{CHS}$ have been deduced from the TOF spectra for $\mathrm{C}_{2} \mathrm{H}_{2} \mathrm{~S}$. By observing the maximum release of translational energy, the bond energies for $c-\mathrm{CH}=\mathrm{CHS}+\mathrm{HC} \equiv \mathrm{CH}, \bullet \mathrm{CHCHS} \bullet+\mathrm{HC} \equiv \mathrm{CH}$ and $\mathrm{SH}+\mathrm{C}=\mathrm{CH}-\mathrm{CH}=\mathrm{CH}$ have been determined to be $113.5 \pm 2,133.5 \pm 2$ and $138 \pm 2 \mathrm{kcal} / \mathrm{mol}$. These values are in agreement with the literature data. Furthermore, due to stepwise photodissociation, it is not surprising that the angular distribution for all of these processes is isotropic. 


\section{Introduction}

Photodissociation of cyclic organic compounds has attracted great interest. ${ }^{1,2,3,4}$ In general, its mechanism involves a single bond cleavage as the primary step, and the transient biradical may further dissociate via different pathways by breakage of various bonds. ${ }^{1}$ In translational photofragmentation spectroscopy, the primary product continues in the direction of the molecular beam due to momentum conservation. Therefore, only the subsequent dissociation of the transient biradical can be observed. The measurement of translational energy release reveals the biradical decay dynamics. Furthermore, the bond energy, including primary and secondary bond breakage, can be inferred by the observation of the maximum translational energy release.

Thiophene is a basic cyclic organic compound in which a sulfur atom is included in the ring. Due to its strong photochemical activity, it is suitable for studying the biradical decay process. Furthermore, thiophene exists in fossil fuels and is a strong poison in many petrochemical engineering processes. Study of this biradical decay provides some insight into the mechanism of this sulfur compound elimination. In this paper, thiophene biradical decay has been studied as the primary laser photofragmentation product at $193 \mathrm{~nm}$.

\section{Experimental}

The rotatable beam source laser photofragmentation apparatus used in this study has been described in detail. ${ }^{5-6}$ The apparatus consists of three main components: an ArF or KrF excimer laser, a photodissociation chamber in which a rotatable supersonic molecular beam 
intersects the laser beam, and a linearly movable ultrahigh vacuum electron ionization mass spectrometric detector.

In this experiment, a pulsed beam of Thiophene ( $5 \%$ seeded in $\mathrm{He}$ ) is produced by supersonic expansion through a commercial pulsed valve(General Valve, No. 9 nozzle diameter $0.5 \mathrm{~mm}$ at $323 \mathrm{~K}$ with a total stagnation pressure of approximately 1535 torr. The pulsed valve is operated at $30 \mathrm{~Hz}$. The seeded thiophene beam has an angular divergence of three degrees which is defined by the opening of the conical skimmer and the circular aperture between the differential chamber and the photodissociation chamber. The three degree angular spread of the beam corresponds to a beam width of $3 \mathrm{~mm}$ in the photodissociation region. The photodissociation chamber is maintained at pressure of $1 \times 10^{-8}$ torr.

The laser (Compact model 205) was operated at approximately $15 \mathrm{~mJ}$ during the experiment, with the light focused to a roughly $5 \mathrm{~mm}^{2}$ spot size at the crossing region of the laser and molecular beams.

The TOF spectra are taken at a flight path distance of $65.5 \mathrm{~cm}$ between the photodissociation region and the ionizer. The emission current of the ionizer is $\sim 1 \mathrm{~mA}$ and the ionization electron energy is $\sim 76 \mathrm{eV}$.

The TOF spectra presented here were recorded on a multi process scaler ( Stanford Research model SRT430) with a process width of $1.28 \mu \mathrm{s}$. The ion drift times through the quadruple mass filter were determined to be $4.114 \mathrm{~m}^{1 / 2} \mu \mathrm{s}$, where $\mathrm{m}$ is the ion mass. The actual flight times of photofragments were corrected for the corresponding ion drift times. 
The velocity distribution of the parent thiophene beam was determined by taking laser hole burning spectra of thiophene ion at $\theta_{1 \mathrm{ab}}=0^{\circ}$. The measured speed profile of species was then fitted to an assumed functional form ${ }^{5,7}, f(v) \sim v^{2} \exp \left[-\left(v-v_{0}\right) / \alpha^{2}\right]$, where $v_{0}$ and $\alpha$ have been determined in these experiments to be $1.35 \times 10^{5} \mathrm{~cm} / \mathrm{s}$ and $2.1 \times 10^{4} \mathrm{~cm} / \mathrm{s}$ respectively.

The analysis of the TOF data was performed by a forward simulation method ${ }^{8-10}$. Briefly, the procedure began with a trial kinetic energy distribution $P\left(E_{c . m}\right)$, which was transformed to a TOF spectrum for comparison with the experimental TOF spectrum. Here, $E_{c . m .}$ represents the center-of-mass kinetic energy of the photofragments. The $P\left(E_{c . m}\right)$ distribution was adjusted until satisfactory agreement between the experimental and calculated TOF data was obtained.

In the measurements of the angular distribution, the laser light was polarized by a stack of ten quartz plates set at the Brewster angle. The electronic vector $\mathrm{E}$ of the polarized laser beam was set perpendicular to the detector and then rotated into the desired direction with a half-wave retarder. The laser energy was measured by a pyroelectric detector, and was kept at $10 \mathrm{~mJ} / \mathrm{pulse}$.

\section{Results and Discussion}

Thiophene belongs to the aromatic group because the lone pair electrons in the sulfur atom join in the conjugated $\pi$ diene system. The lowest electronic transitions upon excitation at $193 \mathrm{~nm}$ are postulated to involve the $\pi-\pi^{*}$ transition. ${ }^{11}$ The absence of local mode excitation at $193 \mathrm{~nm}$ for this molecule indicates that formation of the transient biradical does not support the pathway via bond selective dissociation. However, due to the weak bond of 
C-S, the major transient biradical product is expected to involve C-S bond breakage, as shown in eq. 1. The identification of all dissociation processes in our experiment involved C-S bond breakage, further supporting the hypothesis of the transient state via $\mathrm{C}-\mathrm{S}$ bond breakage. ${ }^{12}$ Although the detection of fragment $\mathrm{C}_{4} \mathrm{H}_{2} \mathrm{~S}$ at beam angle $13^{\circ}$ is assigned to the process of dimer dissociation or hydrogen $\left(\mathrm{H}_{2}\right)$ elimination $\mathrm{C}_{4} \mathrm{H}_{4} \mathrm{~S}$ (Thiophene) $\rightarrow \mathrm{C}_{4} \mathrm{H}_{2} \mathrm{~S}+$ $\mathrm{H}_{2}$ in the primary study of the photodissociation of thiophene in the absence of $\mathrm{H}_{2}$ fragment detection, ${ }^{3}$ the strong signal at $\mathrm{m} / \mathrm{e}^{+} 84\left(\mathrm{C}_{4} \mathrm{H}_{4} \mathrm{~S}\right), 83\left(\mathrm{C}_{4} \mathrm{H}_{3} \mathrm{~S}\right)$, and $82\left(\mathrm{C}_{4} \mathrm{H}_{2} \mathrm{~S}\right)$ at beam angle $10^{\circ}$ in our experiment provides further evidence to identify this process as dimer dissociation.

$(I_{S}$ (Thiophene) $\left.\rightarrow \underbrace{\mid}_{S}\right|_{0}$ (opening ring) $\Delta H=99.7 \mathrm{kcal} / \mathrm{mol}$

\section{1. $\mathrm{HC} \equiv \mathrm{CH}+\mathrm{C}_{2} \mathrm{H}_{2} \mathrm{~S}$ process}

The fragment $\mathrm{C}_{2} \mathrm{H}_{2} \mathrm{~S}$ from dissociation of the transient biradical $\mathrm{C}_{4} \mathrm{H}_{4} \mathrm{~S}$ may exist in several isomers. The heats of formation for three stable isomers of $\mathrm{C}_{2} \mathrm{H}_{2} \mathrm{~S}$ vary greatly (eq. (2), (3) and (4). $)^{2,3,13}$ 


\begin{tabular}{|c|c|c|c|}
\hline $\mathrm{C}_{4} \mathrm{H}_{4} \mathrm{~S}$ (Thiopene) $\rightarrow \bullet$ CHCHS $\bullet$ & + & $\mathrm{HC} \equiv \mathrm{CH}$ & $\Delta \mathrm{H}=128(133.2) \mathrm{kcal} / \mathrm{mol}$ \\
\hline $\mathrm{C}_{4} \mathrm{H}_{4} \mathrm{~S}$ (Thiophene) $\rightarrow c-\mathrm{CH}=\mathrm{CHS}$ & + & $\mathrm{HC} \equiv \mathrm{CH}$ & $\Delta \mathrm{H}=114 \mathrm{kcal} / \mathrm{mol}$ \\
\hline $\mathrm{H} S \mathrm{~S} / \mathrm{T}$ & + & $\mathrm{HC} \equiv \mathrm{CH}$ & $\Delta \mathrm{H}=66 \mathrm{kcal} / \mathrm{mol}$ \\
\hline
\end{tabular}

Due to the kinematic constraint, different populations of translational energy, $P\left(E_{c . m}\right)$, which results in separated /partially overlapped TOF peaks, is expected to be observed when the different isomers are formed. The TOF spectrum for $\mathrm{C}_{2} \mathrm{H}_{2} \mathrm{~S}$ at $\theta_{\text {lab }}=25^{\circ}$ shows a very small fast peak (Fig 2.b), which is amplified at $\theta_{\mathrm{lab}}=30^{\circ}$ (fig 2.d) by truncating the slow part of the peak as the Newton diagram shows ( fig. 1 ). The fitting of these two spectra gives two peaks for the population of translational energy (fig. 3). The maximum of the slow peak is around $5 \mathrm{kcal} / \mathrm{mol}$ and the $\mathrm{p}\left(\mathrm{E}_{\mathrm{c} . \mathrm{m}}\right)$ below this value can not be observed at beam angle $25^{\circ}$. Due to the influence of dimers and clusters, the detection of the slow part of the $P\left(E_{c . m}\right)$ results in a large uncertainty, but the maximum of this $p\left(E_{c . m}\right)$ can be expected to be extended to zero. The maximum of the fast peak is around $21 \mathrm{kcal} / \mathrm{mol}$ and its abundance drops to zero at $16.5 \mathrm{kcal} / \mathrm{mol}$. and $36.5 \mathrm{kcal} / \mathrm{mol}$. The threshold values of 16.5 and $36.5 \mathrm{kcal} / \mathrm{mol}$ are estimated for the slow and the fast peak, respectively. (fig. 3) This observation of the thresholds strongly suggests that the isomers $\mathrm{c}-\mathrm{CH}=\mathrm{CHS}$ and -CHCHS• are formed during the dissociation process. Isomer $\mathrm{c}-\mathrm{CH}=\mathrm{CHS}$ may result from the reconfiguration of $\bullet \mathrm{CHCHS} \bullet$, since the molecule $c-\mathrm{CH}=\mathrm{CHS}$ is much more stable than the biradical $\bullet \mathrm{CHCHS} \bullet$. In that case, the transitional barrier from $\bullet \mathrm{CHCHS} \bullet$ to $c$ - $\mathrm{CH}=\mathrm{CHS}$ is inferred to be small. 


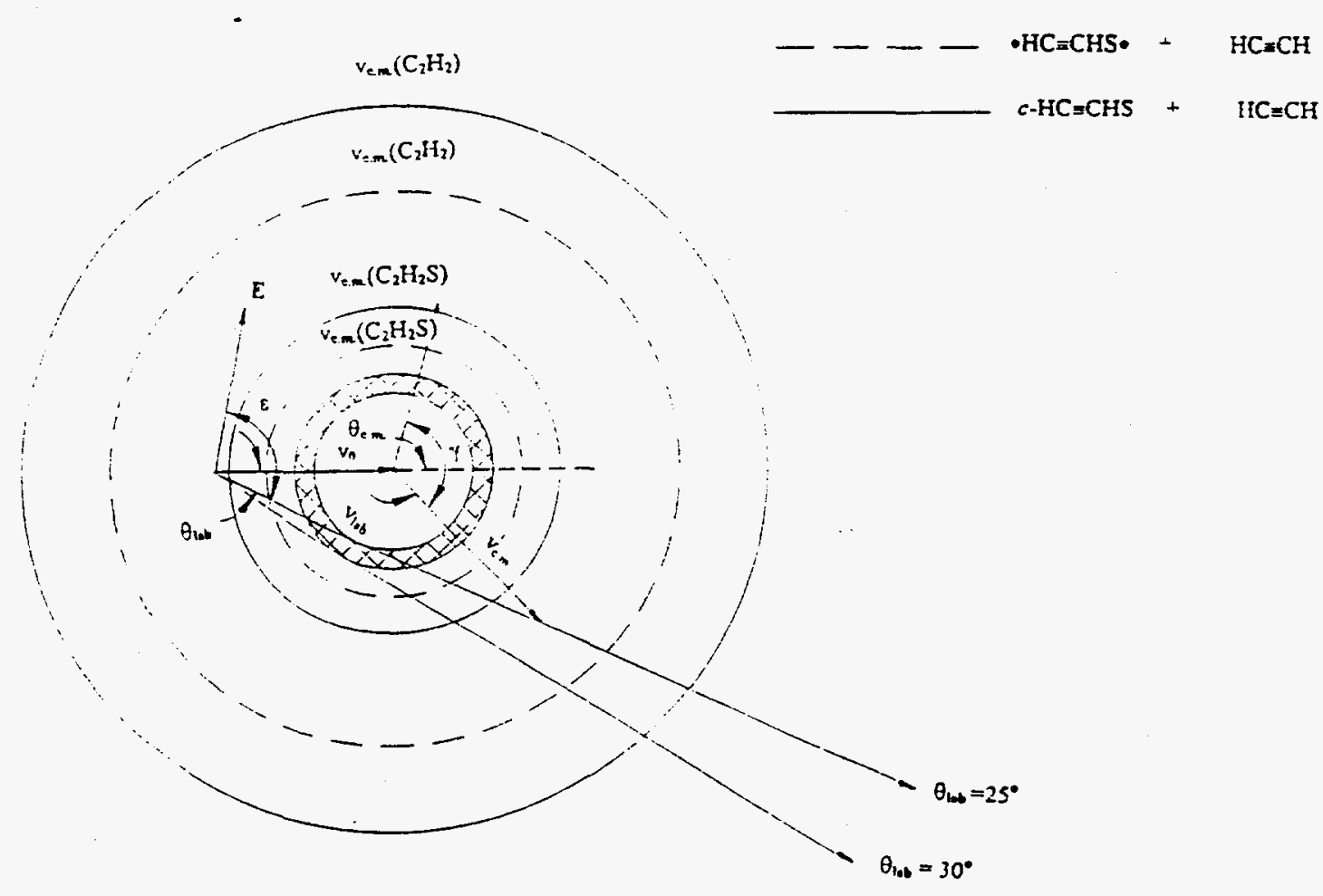

Figure 1. Kinematics for the formation of $c-\mathrm{CH}=\mathrm{CHS}+\mathrm{HC} \equiv \mathrm{CH}$ and $\bullet \mathrm{HC}=\mathrm{CHS} \bullet-$ $\mathrm{HC} \equiv \mathrm{CH} . \mathrm{V}_{\mathrm{o}}$ is the laboratory velocity for $\mathrm{C}_{4} \mathrm{H}_{4} \mathrm{~S}$, and $\mathrm{v}_{\mathrm{c} . \mathrm{m}}\left(\mathrm{C}_{2} \mathrm{H}_{2} \mathrm{~S}\right)$ and $\mathrm{v}_{\mathrm{c} . \mathrm{m}}\left(\mathrm{C}_{2} \mathrm{H}_{2}\right)$ are the maximum c.m. velocities for $\mathrm{C}_{2} \mathrm{H}_{2} \mathrm{~S}$ and $\mathrm{C}_{2} \mathrm{H}_{2}$, respectively. The truncated part has been shaded when the molecular beam angle increases from $25^{\circ}$ to $30^{\circ}$. The diagrams also show the relationship $\gamma=\theta_{\mathrm{cm}}+\varepsilon-\theta_{\mathrm{lbb}}$, where $\gamma$ is the angie between the laser electric field $(E)$ and the c.m. photofragment velocity; $\theta_{c m}$ is the angle between the molecular beam velocity and the fragment recoil c.m. veiocity; $\varepsilon$ is the angle between $E$ and detector axis; and $\theta_{1 b b}$ is the angle between the molecular beam velocity and the detector axis. 


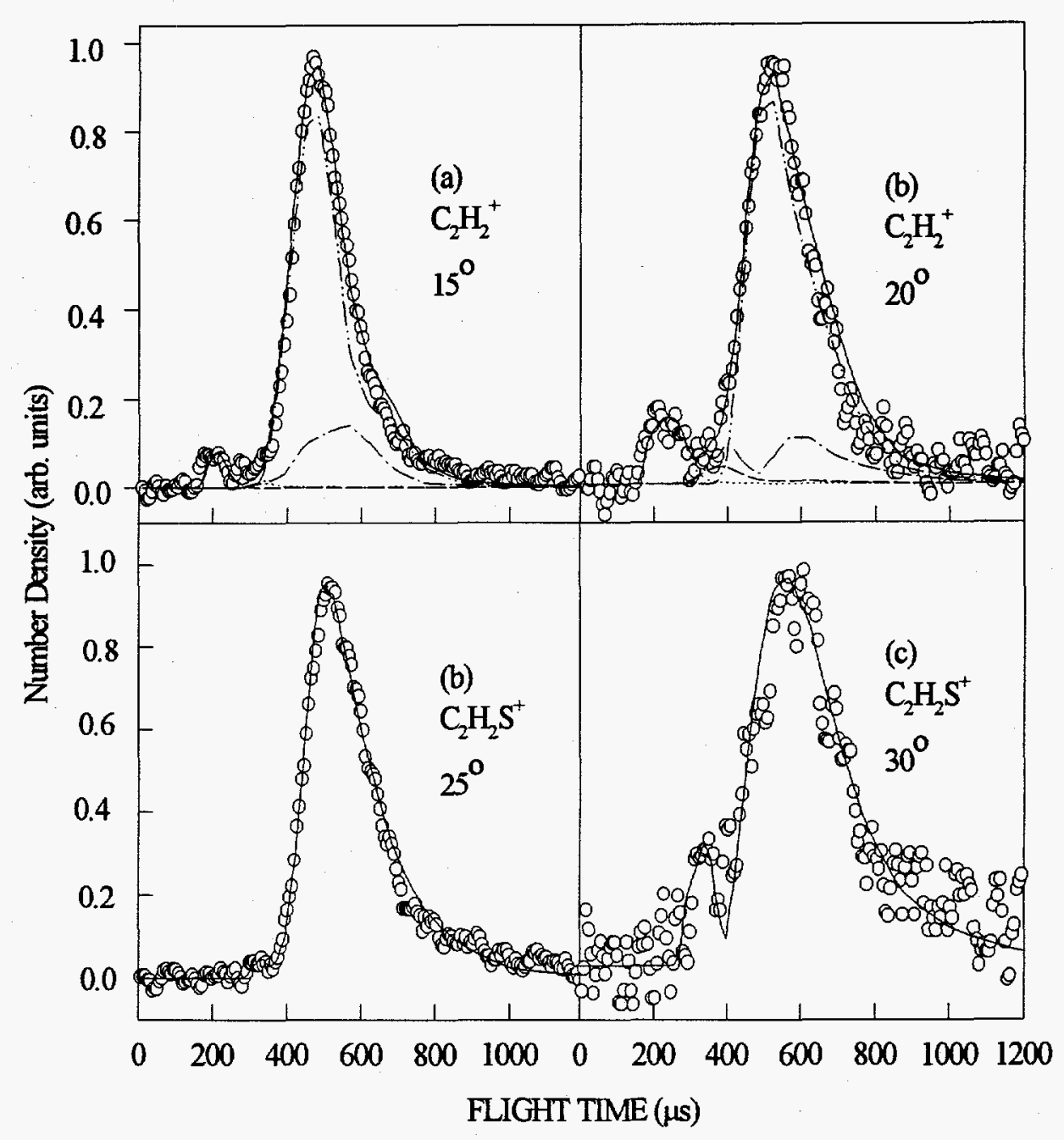

Figure 2. TOF spectra obtained for $\mathrm{C}_{2} \mathrm{H}_{2}$ and $\mathrm{C}_{2} \mathrm{H}_{2} \mathrm{~S}$ at $\theta_{\text {lab }}=15^{\circ}, 20^{\circ}, 25^{\circ}$, and $30^{\circ}$. Circles represent the experimental data. The solid line is a best fit. Contributions are shown in fig. 2 (a) and (b) for $\mathrm{C}_{3} \mathrm{H}_{3}$ (dot-dot-dash line), $\mathrm{C}_{2} \mathrm{H}_{2} \mathrm{~S}$ (dot-dash line), $\mathrm{C}_{2} \mathrm{H}_{2}$ (dashed line), $\mathrm{C}_{2} \mathrm{H}_{2}$ from secondary dissociation (dotted line). 


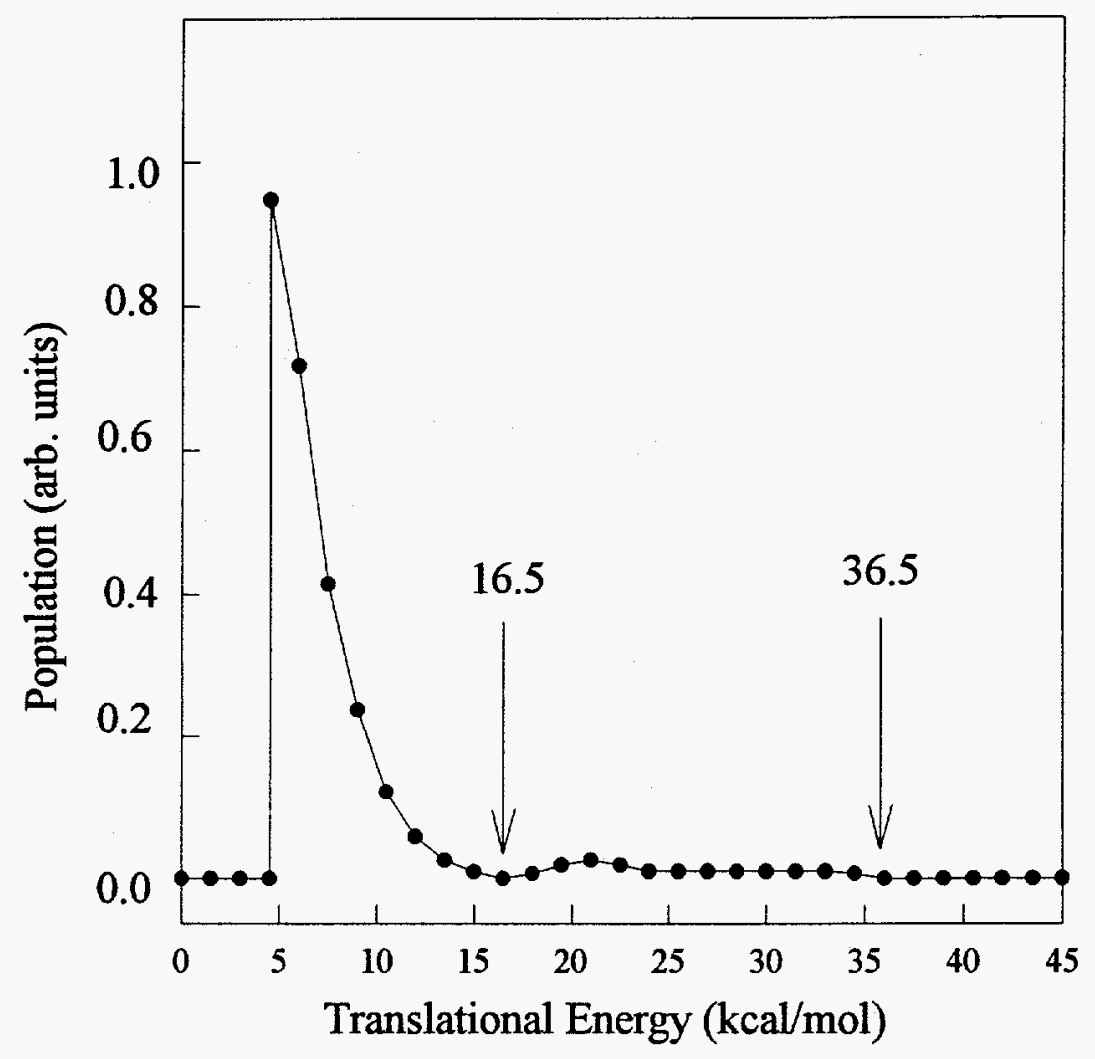

Figure 3. $E_{c . m}$ distribution $\left[P\left(E_{c . m}\right)\right]$ for process (1) derived by fitting the TOF spectra for $\mathrm{C}_{2} \mathrm{H}_{2} \mathrm{~S}$ and $\mathrm{C}_{2} \mathrm{H}_{2}$. 
TOF spectra for $\mathrm{C}_{2} \mathrm{H}_{2}$, a counterpart of $\mathrm{C}_{2} \mathrm{H}_{2} \mathrm{~S}$, are much weaker. This may be due to the lower ionization efficiency of $\mathrm{HC} \equiv \mathrm{CH}$. The TOF spectra for $\mathrm{C}_{2} \mathrm{H}_{2}$ can not be fit by $P\left(E_{c . m}\right)$ derived from TOF spectra for $\mathrm{C}_{2} \mathrm{H}_{2} \mathrm{~S}$ ( dashed curve), indicating that other processes are involved in the spectra. We expect that $\mathrm{C}_{2} \mathrm{H}_{2}{ }^{+}$fragment ions formed in the electron ionization of $\mathrm{C}_{2} \mathrm{H}_{2} \mathrm{~S}$ contribute to the spectra for $\mathrm{C}_{2} \mathrm{H}_{2}$.

$$
\mathrm{C}_{2} \mathrm{H}_{2} \mathrm{~S}+\mathrm{e}^{-} \rightarrow \mathrm{C}_{2} \mathrm{H}_{2}^{+}+\mathrm{S}+2 \mathrm{e}^{-}
$$

However, this contribution ( dot-dash curve) does not fit the slow, large peak. We note that the photofragment $\mathrm{C}_{3} \mathrm{H}_{3}$ can be ionized to form $\mathrm{C}_{2} \mathrm{H}_{2}{ }^{+}$:

$$
\mathrm{C}_{3} \mathrm{H}_{3}+\mathrm{e}^{-} \rightarrow \mathrm{C}_{2} \mathrm{H}_{2}^{+}+\mathrm{CH}+2 \mathrm{e}^{-}
$$

Therefore, the $\mathrm{P}\left(\mathrm{E}_{\text {c.m. }}\right)$ derived from TOF spectra for $\mathrm{C}_{3} \mathrm{H}_{3}$ is used to fit the spectra for $\mathrm{C}_{2} \mathrm{H}_{2}$ ( dot-dot-dash curve). A very fast peak appears in fig.2a and fig.2b., and shows laser energy independence, excluding the two photo effects. Only the secondary dissociation of the radical $c-\mathrm{CH}=\mathrm{CHS}$ can produce the fast signal by abandoning the sulfur atom. Therefore, this fast peak (dotted line) is assigned to the secondary dissociation :

$$
c-\mathrm{CH}=\mathrm{CHS} \rightarrow \mathrm{HC} \equiv \mathrm{CH}+\mathrm{S}
$$


It is very interesting that the fastest signals are observed in TOF spectra for $\mathrm{S}$ and $\mathrm{SH}$ in both our and J. D. Mayers's experiments ${ }^{3}$, and that this secondary $P\left(E_{\text {c.m }}\right)$ (fig. 4) fits the fastest signal of SH quite well due to the S mass leakage.

\section{2. $\mathrm{S}+\mathrm{C}_{4} \mathrm{H}_{4}$ Process}

A $\mathrm{P}\left(\mathrm{E}_{\mathrm{c} . \mathrm{m}}\right)$ of $\mathrm{S}+\mathrm{C}_{4} \mathrm{H}_{4}$ Process can be derived from TOF spectra for $\mathrm{C}_{4} \mathrm{H}_{4}$ (fig.5). The signal from $\mathrm{C}_{4} \mathrm{H}_{3}$ may also contribute to this spectrum due to the mass leakage. However, since the mass leakage ratio is unknown and the signal from $\mathrm{C}_{4} \mathrm{H}_{3}$ resides in the slow part of TOF spectra for $\mathrm{C}_{4} \mathrm{H}_{4}$, the contribution from $\mathrm{C}_{4} \mathrm{H}_{3}$ is ignored in fitting the TOF spectra for $\mathrm{C}_{4} \mathrm{H}_{4}$. A threshold of this $\mathrm{P}\left(\mathrm{E}_{\mathrm{c} . \mathrm{m}}\right)$ (fig. 6) is accurately determined at 15.5 $\mathrm{kcal} / \mathrm{mol}$, and the $\mathrm{P}\left(\mathrm{E}_{\mathrm{c.m}}\right)$ can be measured down to $2 \mathrm{kcal} / \mathrm{mol}$, but is expected to extend to zero. The heats of formation of three stable isomers are shown in eq. $8,9,10,{ }^{2}$ and the measurement $\mathrm{P}\left(\mathrm{E}_{\mathrm{c} . \mathrm{m}}\right)$ for $\mathrm{S}+\mathrm{C}_{4} \mathrm{H}_{4}$ Process suggests that the biradical fragment preferably forms the stable molecule $\mathrm{CH}_{2}=\mathrm{C}=\mathrm{C}=\mathrm{CH}_{2}$.

$$
\begin{aligned}
& \mathrm{C}_{4} \mathrm{H}_{4} \mathrm{~S} \text { (Thiophene) } \rightarrow \mathrm{CH}_{2}=\mathrm{CH}-\mathrm{C} \equiv \mathrm{CH}+\mathrm{S}\left({ }^{3} \mathrm{P}\right) \quad \Delta \mathrm{H}=12 \mathrm{kcal} / \mathrm{mol} \\
& \mathrm{C}_{4} \mathrm{H}_{4} \mathrm{~S} \text { (Thiopene) } \rightarrow \mathrm{CH}_{2}=\mathrm{C}=\mathrm{C}=\mathrm{CH}_{2}+\mathrm{S}\left({ }^{3} \mathrm{P}\right) \quad \Delta \mathrm{H}=122 \mathrm{kcal} / \mathrm{mol} \\
& \mathrm{C}_{4} \mathrm{H}_{4} \mathrm{~S} \text { (Thiophene) } \rightarrow \mathrm{H}_{2} \mathrm{C}=\mathrm{C}-\mathrm{C}=\mathrm{CH}_{2}+\mathrm{S}\left({ }^{3} \mathrm{P}\right) \quad \Delta \mathrm{H}=140 \mathrm{kcal} / \mathrm{mol}
\end{aligned}
$$




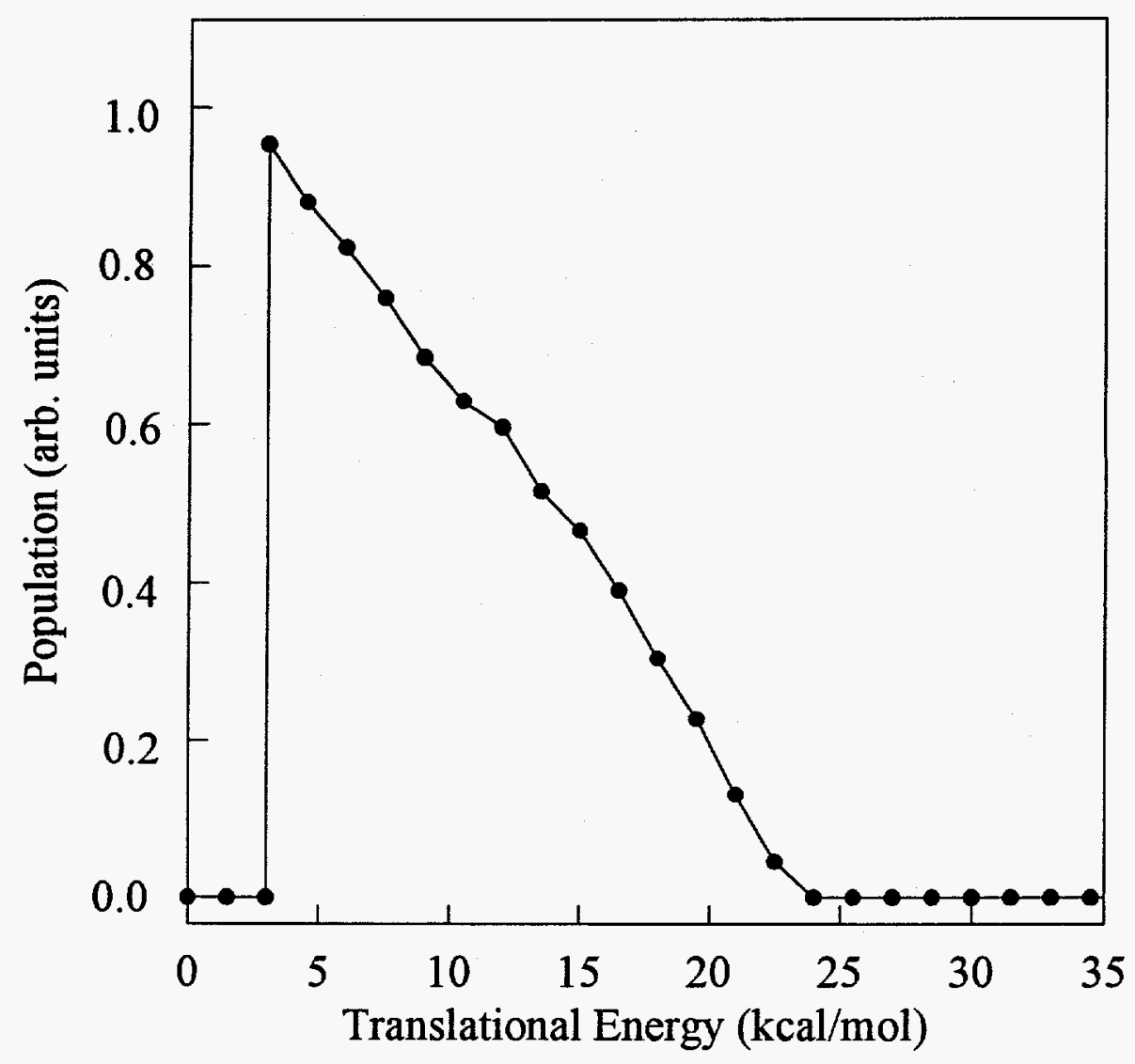

Figure 4. $P\left(E_{c . m}\right)$ for the secondary dissociation process (7). 


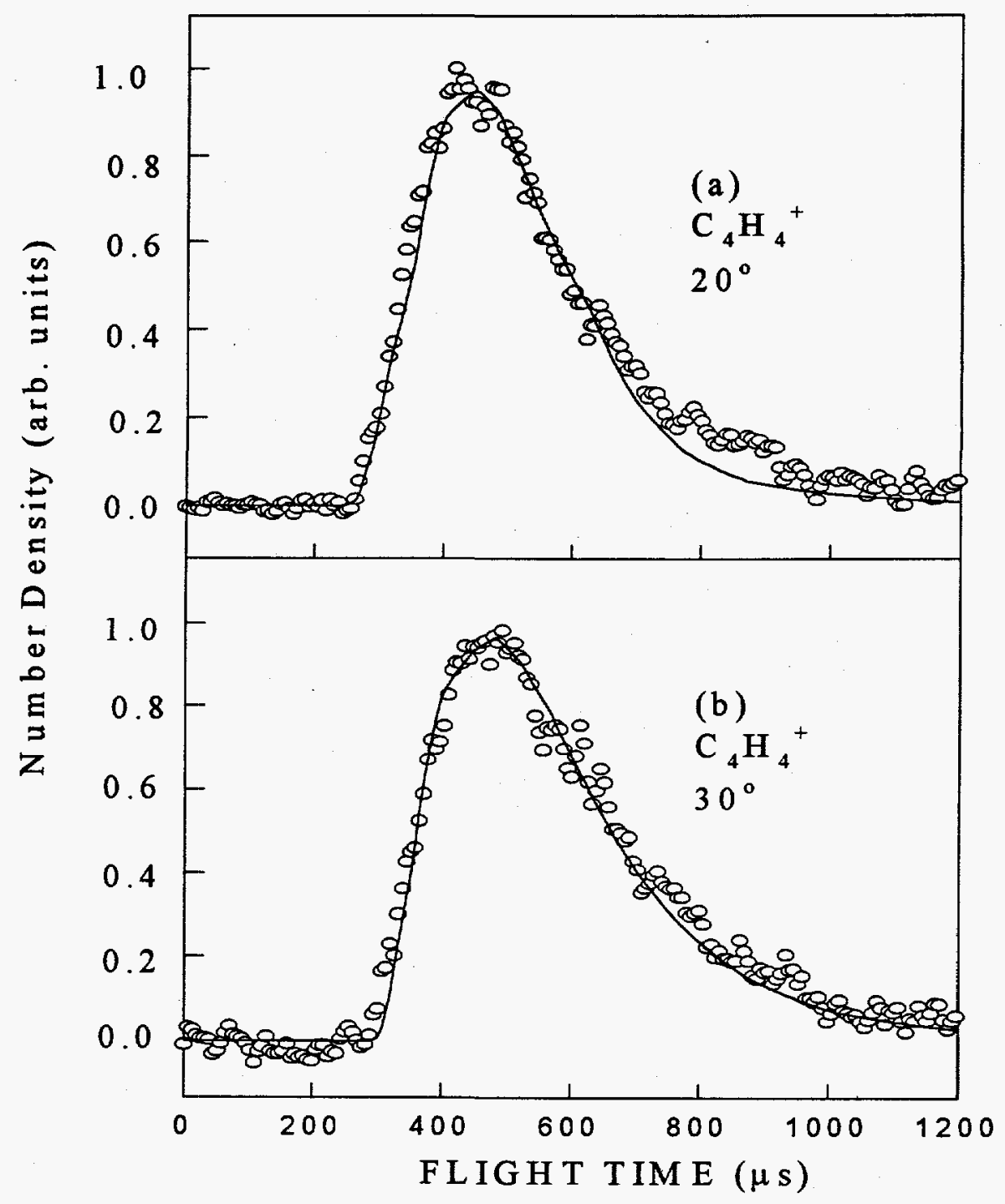

Figure 5. TOF spectra for $S$ obtained at (a) $\theta_{\mathrm{lab}}=20^{\circ}$ and (b) $\theta_{\mathrm{lab}}=30^{\circ}$. Circles represent experimental data. The solid line is a best fit using $P\left(E_{c . m}\right)$ from fig.6. 


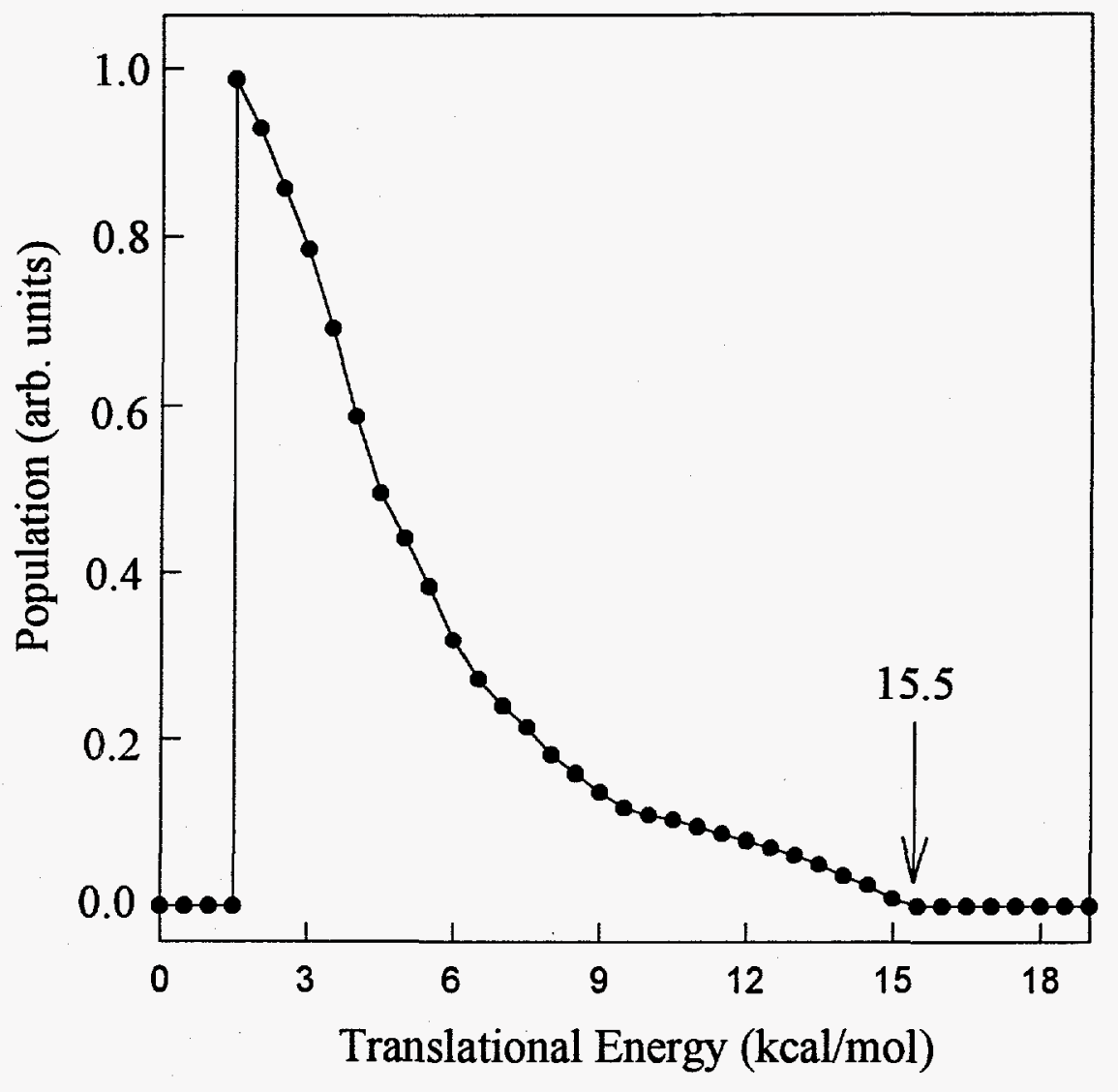

Figure 6. $E_{c . m}$ distribution $\left[P\left(E_{c . m}\right)\right]$ for process (2) derived by fitting the TOF spectra for $S$ at $\theta_{\mathrm{lab}}=20^{\circ}$ and $\theta=30^{\circ}$. 
The detection of the signal for $\mathrm{S}$ was unsuccessful, due to strong background from $\mathrm{O}_{2}$. However, the information for $\mathrm{S}$ can be further obtained from TOF spectra for SH due to the mass leakage.

\section{3. $\mathrm{C}_{3} \mathrm{H}_{3}+$ HCS Process}

TOF spectra for $\mathrm{C}_{3} \mathrm{H}_{3}$ and HCS are shown in fig.7, and the $\mathrm{P}\left(\mathrm{E}_{\mathrm{c.m}}\right)$ (fig. 8) derived from TOF spectra for HCS fits the TOF spectra for $\mathrm{C}_{3} \mathrm{H}_{3}$ quite well (dashed curve), indicating that only one process has happened. The possible processes and their heats of formation are listed in eq. $11,12,13 .^{13}$

$$
\begin{array}{lr}
\mathrm{C}_{4} \mathrm{H}_{4} \mathrm{~S} \text { (Thiophene) } \rightarrow \mathrm{HCS}+\mathrm{HC} \equiv \mathrm{C}-\mathrm{CH}_{2} & \Delta \mathrm{H}=110 \mathrm{kcal} / \mathrm{mol} \\
\mathrm{C}_{4} \mathrm{H}_{4} \mathrm{~S} \text { (Thiophene) } \rightarrow \mathrm{HCS}+\mathrm{HC}=\mathrm{CH}-\mathrm{CH} \bullet & \Delta \mathrm{H}=144 \mathrm{kcal} / \mathrm{mol} \\
\mathrm{C}_{4} \mathrm{H}_{4} \mathrm{~S} \text { (Thiophene) } \rightarrow \mathrm{HCS}+\mathrm{HC}=\mathrm{C}-\mathrm{CH}_{2} & \Delta \mathrm{H}=153 \mathrm{kcal} / \mathrm{mol}
\end{array}
$$

The translational energy release can be measured down to $1 \mathrm{kcal} / \mathrm{mol}$ and probably extends to zero. The maximum translational energy release occurs at $4 \mathrm{kcal} / \mathrm{mol}$, supporting that the isomer $\mathrm{HC}=\mathrm{CH}-\mathrm{CH} \bullet$ is formed in the photodissociation process. A very small fast peak in the TOF spectra for $\mathrm{C}_{3} \mathrm{H}_{3}$ has been observed, and this peak can be fit by $\mathrm{P}\left(\mathrm{E}_{\text {c.m }}\right)$ for $\mathrm{C}_{3} \mathrm{H}_{4}$ due the mass leakage ( dot-dash curve).

\section{4. $\mathrm{CS}+\mathrm{C}_{3} \mathrm{H}_{4}$ Process}

TOF spectra for $\mathrm{CS}$ and $\mathrm{C}_{3} \mathrm{H}_{4}$ are depicted in fig. 9. Since the signal from CS is hard to detect due to the large background from $\mathrm{CO}_{2}$, the mass has been tuned up to $\approx 44.3 \mathrm{in}$ 

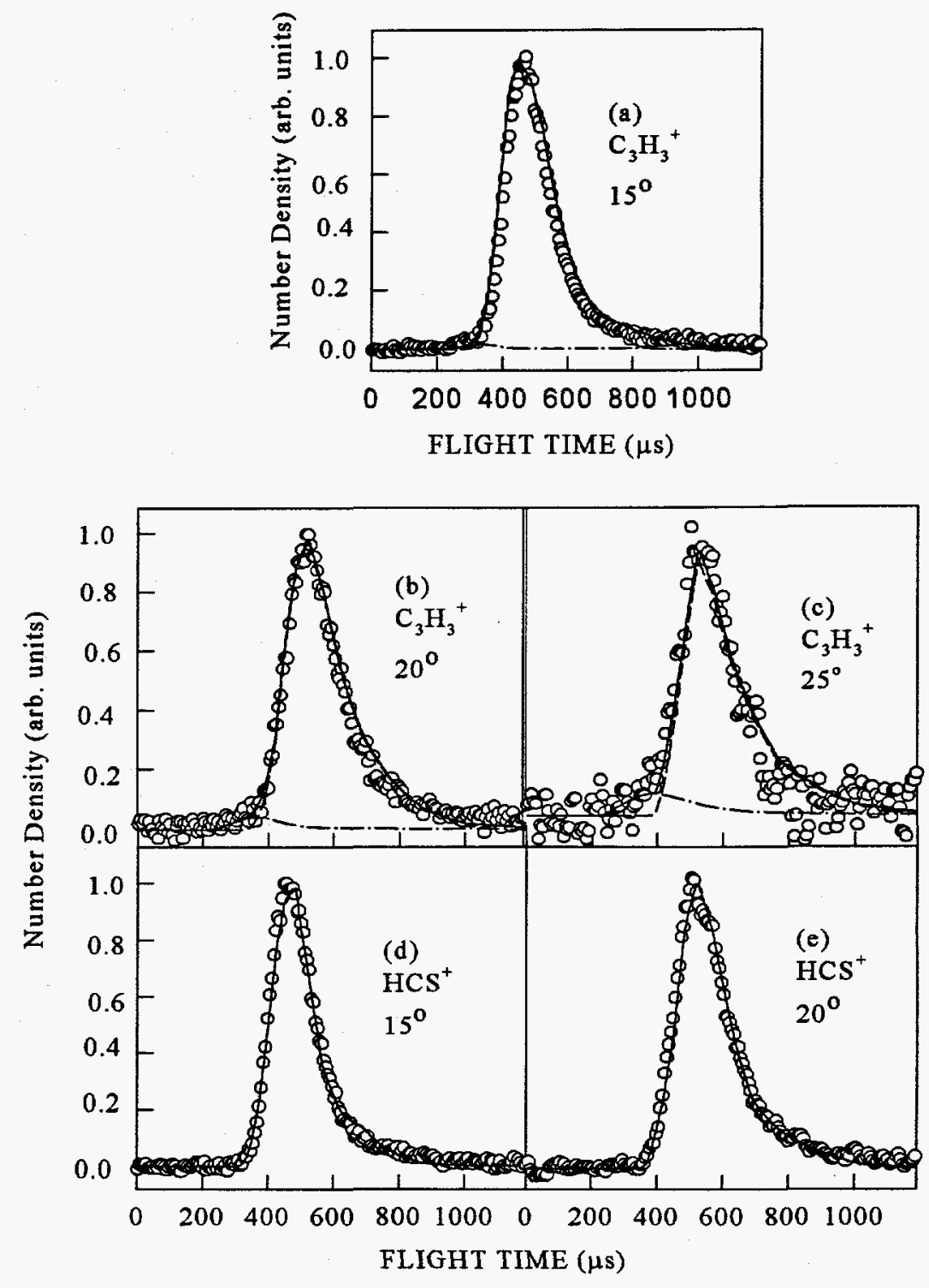

Figure 7. TOF spectra obtained for $\mathrm{C}_{3} \mathrm{H}_{3}$ and HCS at $\theta_{\mathrm{lab}}=15^{\circ}, 20^{\circ}$, and $25^{\circ}$. Circles represent the experimental data. The solid line is a best fit. Contributions are shown in fig. 7 (a), (b), and (c) for $\mathrm{C}_{3} \mathrm{H}_{3}$ (dashed line), and $\mathrm{C}_{3} \mathrm{H}_{4}$ (dot-dash line). 


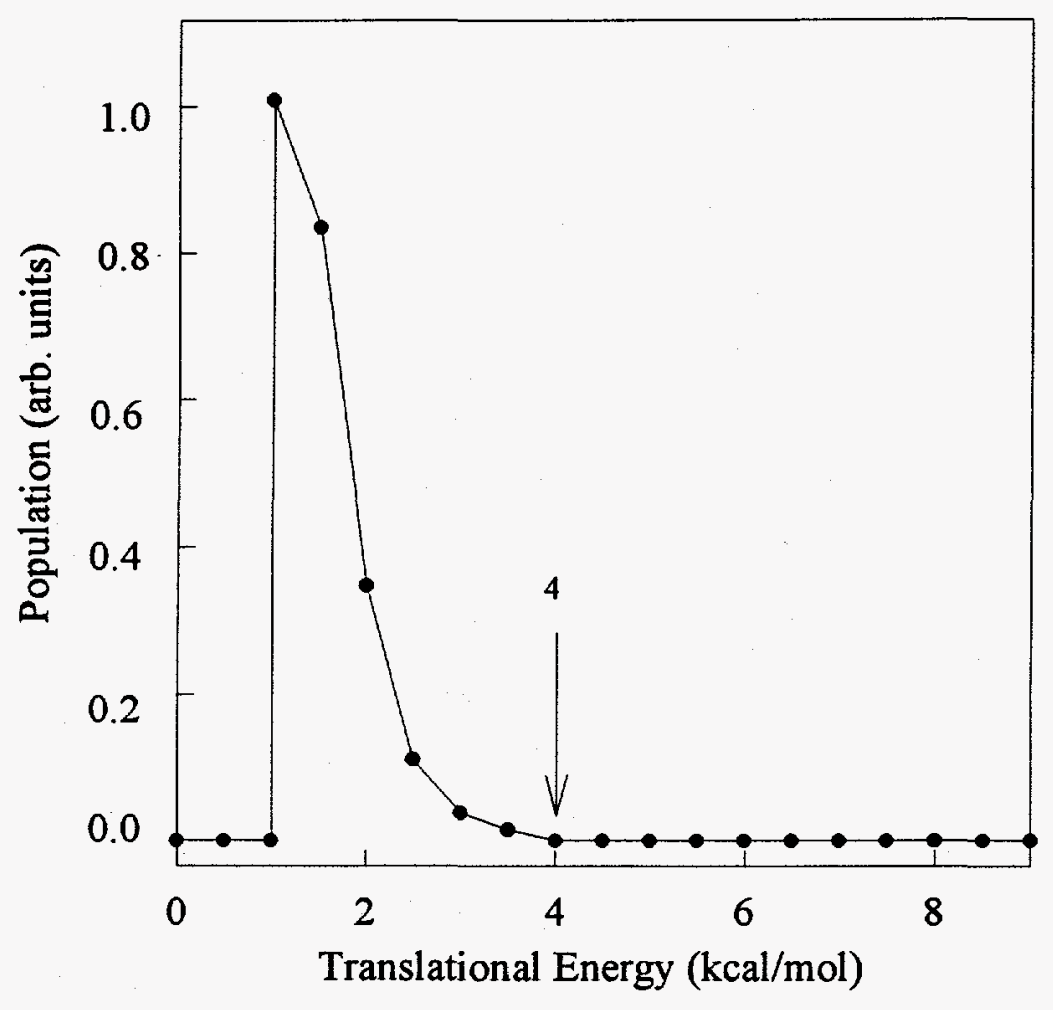

Figure 8. $E_{c . m}$ distribution $\left[P\left(E_{c . m}\right)\right]$ for process (3) derived by fitting the TOF spectra for $\mathrm{C}_{3} \mathrm{H}_{3}$ and $\mathrm{HCS}$ 
order to avoid the large noise. Therefore, it is not surprising that the big slow peak (dot-dash curve) can be fit by the $P\left(E_{c . m}\right)$ derived from HCS due to the large mass leakage. The derived $\mathbf{P}\left(\mathrm{E}_{\mathrm{c} . \mathrm{m}}\right.$ ) from the fast peak ( dashed line) is shown in (fig.10). TOF spectra for $\mathrm{C}_{3} \mathrm{H}_{4}$ only show a small fast peak (dashed curve), indicating that this is a minor process. The large slow peak ( dot-dash curve) is fit by the $\mathrm{P}\left(\mathrm{E}_{\text {c.m. }}\right)$ derived from $\mathrm{C}_{3} \mathrm{H}_{3}$. The maximum translational energy release is $\approx 30 \mathrm{kcal} / \mathrm{mol}$, and $\mathrm{P}\left(\mathrm{E}_{\mathrm{c} . \mathrm{m}}\right)$ peaks near zero. All of these observations are consistent with J. D. Myers results. ${ }^{3}$

\section{5. $\mathrm{SH}+\mathrm{C}_{4} \mathrm{H}_{3}$ Process}

TOF spectra for $\mathrm{C}_{4} \mathrm{H}_{3}$ are shown in fig. 11 (c) and fig. 11(d). The fitting shows that the contribution from $\mathrm{C}_{4} \mathrm{H}_{4}$ is small, due to mass leakage (dot-dash line). The derived $\mathrm{P}\left(\mathrm{E}_{\mathrm{c} . \mathrm{m}}\right.$ ) (fig.12) peaks at $1 \mathrm{kcal} / \mathrm{mol}$ and is expected to extend to zero. The threshold of this $\mathrm{P}\left(\mathrm{E}_{\mathrm{c.m} . \mathrm{m}}\right)$ is $\approx 12 \mathrm{kcal} / \mathrm{mol}$, indicating that process (14) occurs.

$\mathrm{C}_{4} \mathrm{H}_{4} \mathrm{~S}$ (Thiophene) $\rightarrow \mathrm{SH}+\mathrm{C}=\mathrm{CH}-\mathrm{CH}=\mathrm{CH} \quad \Delta \mathrm{H}=140.2 \mathrm{kcal} / \mathrm{mol}$

The fitting of TOF spectra for $\mathrm{SH}$ is much more complex due to the mass leakage.

The fitting shows contributions are made from SH( dashed curve), S (dot-dash curve), and HCS ( dot-dot-dash curve) due to ionization process (15):

$$
\mathrm{HCS}+\mathrm{e}^{-} \rightarrow \mathrm{S}^{+}+\mathrm{HC}+2 \mathrm{e}^{-}
$$




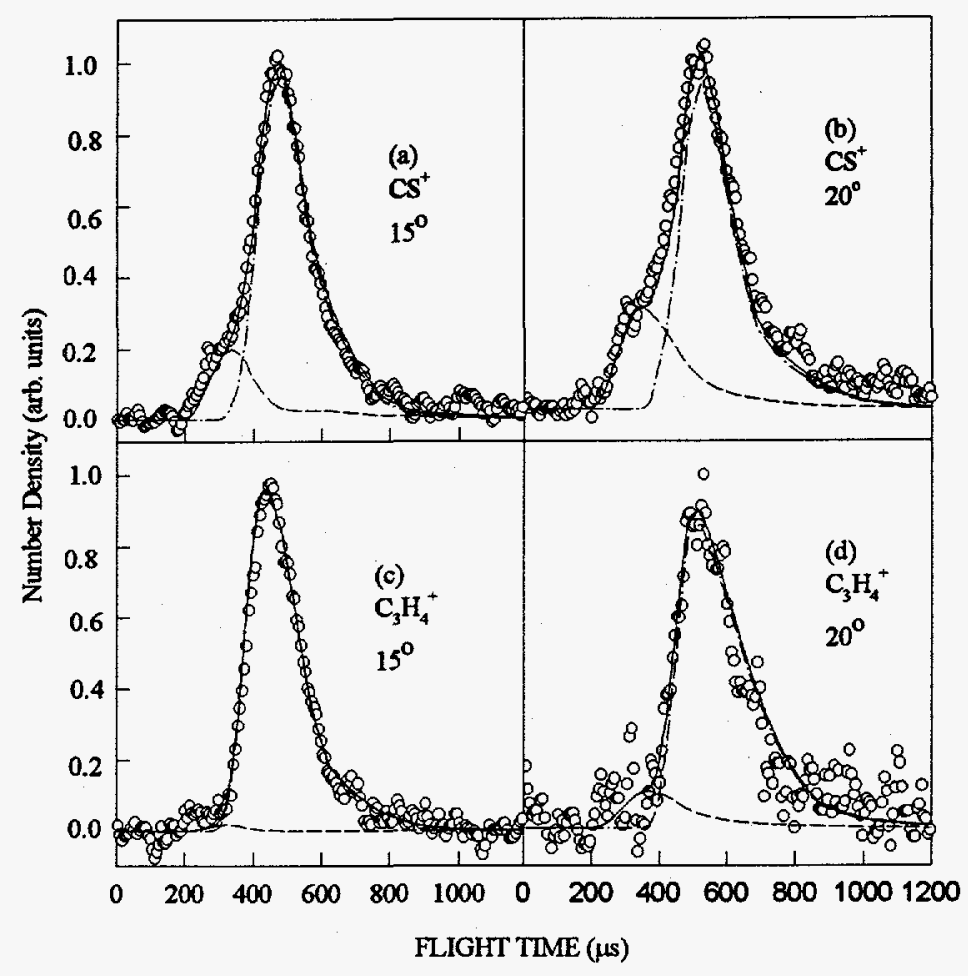

Figure 9. TOF spectra for $\mathrm{CS}$ and $\mathrm{C}_{3} \mathrm{H}_{4}$ at $\theta_{\mathrm{lab} .}=15^{\circ}$, and $20^{\circ}$. Circles represent the experimental data. The solid line is a best fit. Contributions are shown in fig. 9 (a) and (b) for CS ( dashed line), and HCS ( dot-dash line). Contributions are shown in fig. 9 (c) and (d) for $\mathrm{C}_{3} \mathrm{H}_{4}$ ( dashed line), and $\mathrm{C}_{3} \mathrm{H}_{3}$ ( dot-dash line). 


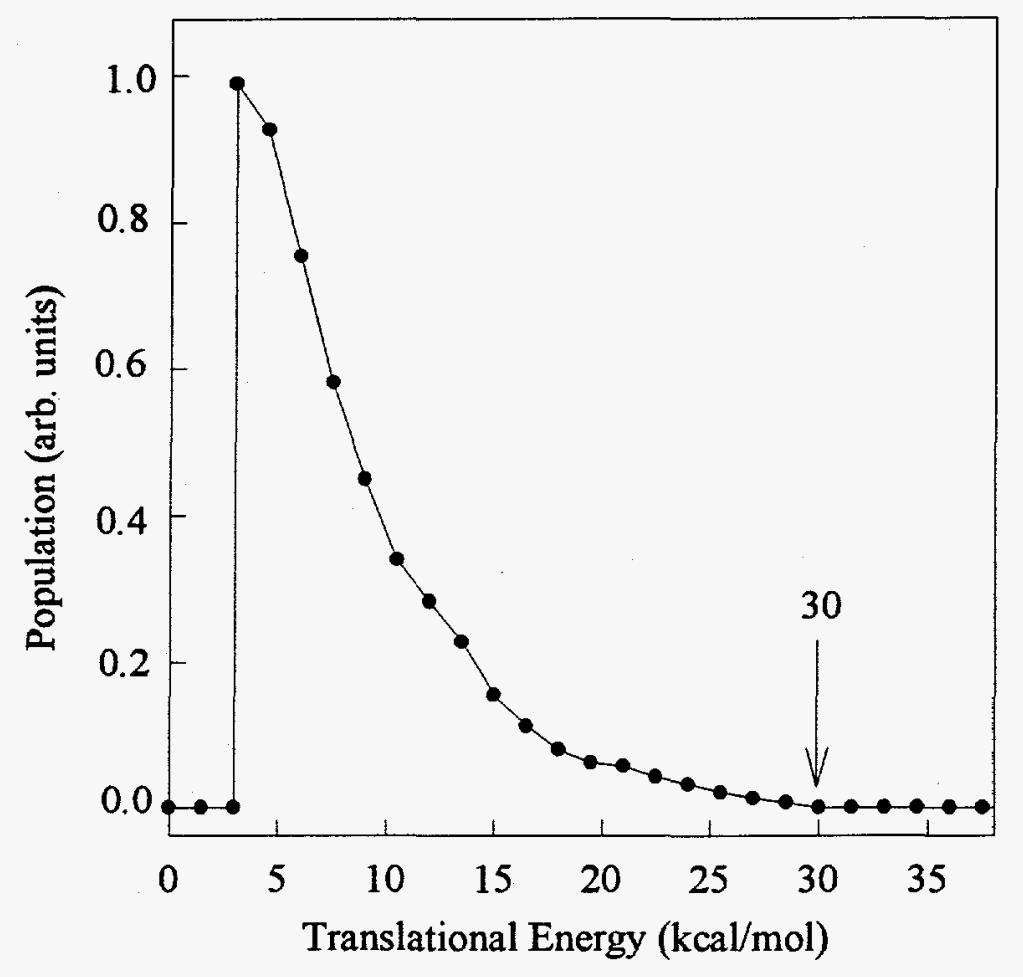

Figure 10. $E_{\text {c.m }}$ distribution $\left[P\left(E_{c . m}\right)\right]$ for process (4) derived by fitting the TOF spectra for $\mathrm{CS}$ and $\mathrm{C}_{3} \mathrm{H}_{4}$ at $\theta_{\mathrm{lab}}=15$ and $20^{\circ}$. 


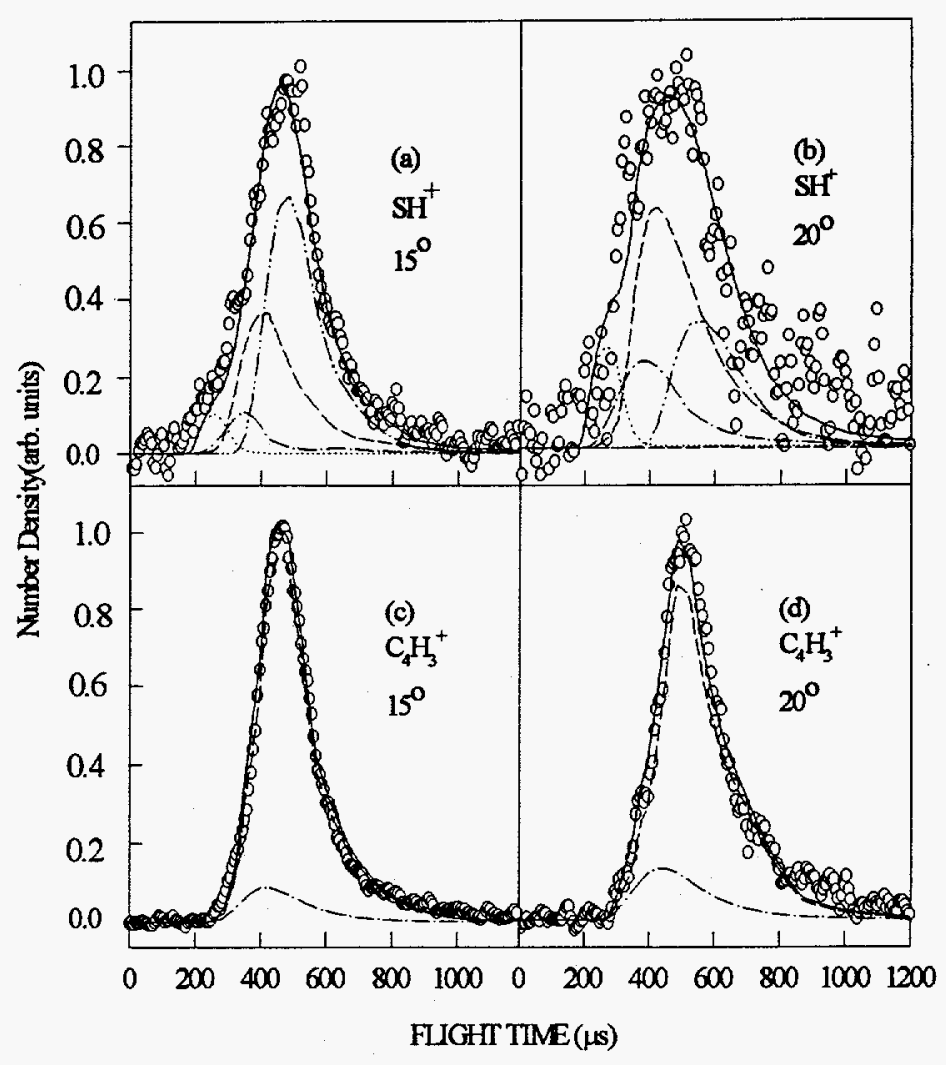

Figure 11. TOF spectra for $\mathrm{SH}$ and $\mathrm{C}_{4} \mathrm{H}_{3}$ at $\theta_{\mathrm{lab}}=15^{\circ}$ and $20^{\circ}$. Circles represent the experimental data. The solid line is a best fit. Contributions are shown in fig.11 (a) and (b) for SH (dashed line), S(dot-dash line), HCS(dot-dot-dash line), and S from process (7) (dotted line). Contributions are shown in fig. 11 (c) and (d) for $\mathrm{C}_{4} \mathrm{H}_{3}$ (dashed line), and $\mathrm{C}_{4} \mathrm{H}_{4}$ (dot-dash line). 


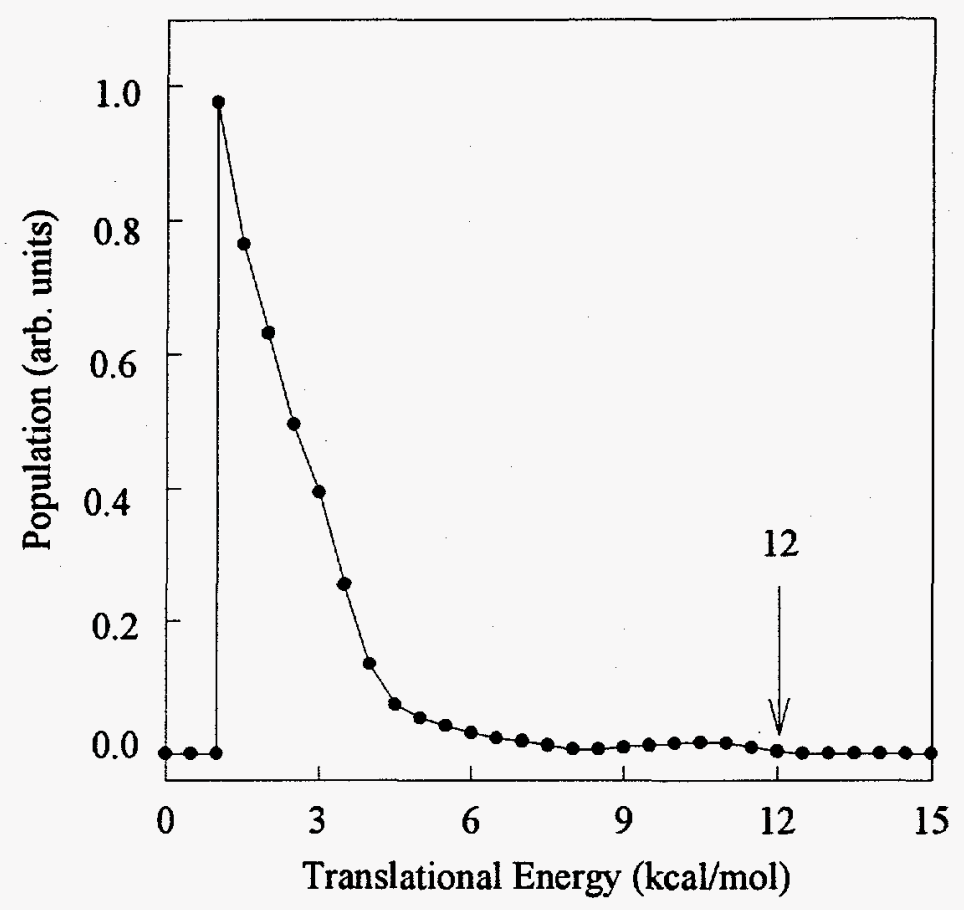

Figure 12. $\mathrm{E}_{\mathrm{c} . \mathrm{m}}$ distribution $\left[\mathrm{P}\left(\mathrm{E}_{\mathrm{c.m}}\right)\right]$ for process (5) derived by fitting the TOF spectra for $\mathrm{SH}$ and $\mathrm{C}_{3} \mathrm{H}_{4}$ at $\theta_{\mathrm{lab}}=15$ and $20^{\circ}$ 

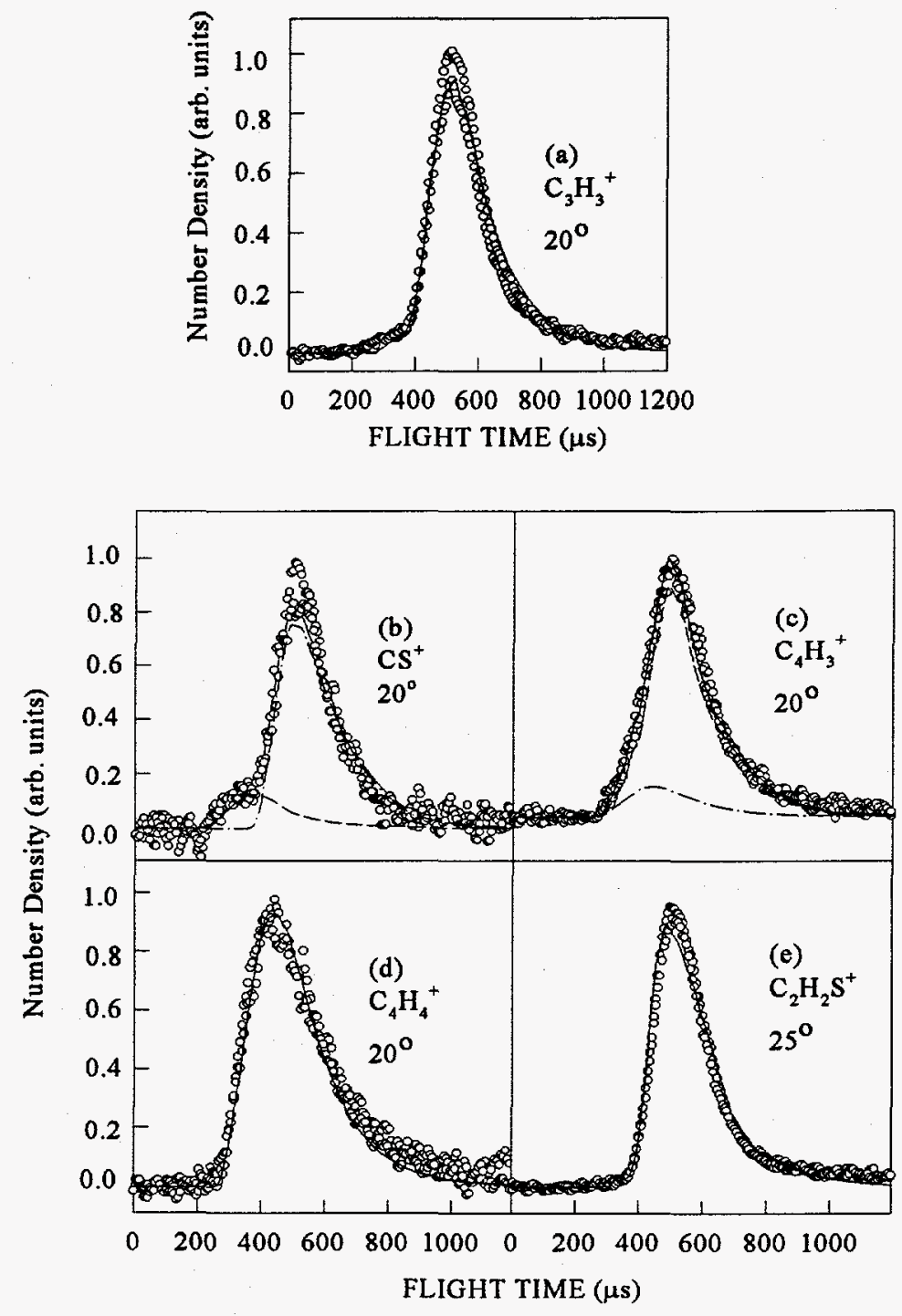

Figure 13. The TOF spectra observed at $\varepsilon=0^{\circ}$, and $90^{\circ}$ for $\mathrm{C}_{3} \mathrm{H}_{3}, \mathrm{CS}, \mathrm{C}_{4} \mathrm{H}_{3}$, and $\mathrm{C}_{4} \mathrm{H}_{4}$ at $\theta_{\text {lab. }}$. $=20^{\circ}$, and $\mathrm{C}_{2} \mathrm{H}_{2} \mathrm{~S}$ at $\theta_{\text {lab. }}=25^{\circ}$ 
The $\mathrm{S}$ from minor process $\left(\mathrm{CS}+\mathrm{C}_{3} \mathrm{H}_{4}\right)$ appears in the same position as $\mathrm{S}$ from process ( $\left.\mathrm{C}_{4} \mathrm{H}_{4}\right)+\mathrm{S}$ ) and is neglected in the fitting. A small fast peak appears in the TOF spectra for SH and cannot fit by the primary processes. It is interesting that J. D. Mayers's TOF spectra ${ }^{3}$ for SH and S also show a small fast peak that does not fit. We note that J. D. Mayers excluded the secondary dissociation (7) in the fitting. However, this small peak can be fit by the $\mathrm{P}\left(\mathrm{E}_{\mathrm{c.m}}\right)$ of the dissociation process (7) derived from TOF spectra for $\mathrm{C}_{2} \mathrm{H}_{2}$ in our experiment.

The Angular Distribution

The stepwise photodissociation mechanism for cyclic compounds is further confirmed by the measurements of the angular distribution for the above processes. The isotropy results of the above processes are expected if the stepwise photodissociation processes occur. TOF spectra for fragments (a) $\mathrm{C}_{3} \mathrm{H}_{3}$, (b) $\mathrm{CS}$, (c) $\mathrm{C}_{4} \mathrm{H}_{3}$, (d) $\mathrm{C}_{4} \mathrm{H}_{4}$, and (e) $\mathrm{C}_{2} \mathrm{H}_{2} \mathrm{~S}$ have been measured at $\varepsilon=0^{\circ}$ and $\varepsilon=90^{\circ}$ ( fig. 13 ). The intensities of TOF spectra for the five fragments remain constant, indicating that all five processes are isotropic.

\section{Conclusion}

The photodissociation of thiophene, a cyclic organic compound, reveals the different pathways that the transient biradical decays by breakage of different bonds. Five dissociation processes have been identified as follows:

$$
\begin{aligned}
& \mathrm{C}_{4} \mathrm{H}_{4} \mathrm{~S} \text { (Thiophene) } \rightarrow \mathrm{HC} \equiv \mathrm{CH}+\mathrm{C}_{2} \mathrm{H}_{2} \mathrm{~S} \\
& \mathrm{C}_{4} \mathrm{H}_{4} \mathrm{~S} \text { (Thiophene) } \rightarrow \mathrm{S}+\mathrm{C}_{4} \mathrm{H}_{4}
\end{aligned}
$$




$$
\begin{aligned}
& \mathrm{C}_{4} \mathrm{H}_{4} \mathrm{~S} \text { (Thiophene) } \rightarrow \mathrm{C}_{3} \mathrm{H}_{3}+\mathrm{HCS} \\
& \mathrm{C}_{4} \mathrm{H}_{4} \mathrm{~S} \text { (Thiophene) } \rightarrow \mathrm{CS}+\mathrm{C}_{3} \mathrm{H}_{4} \\
& \mathrm{C}_{4} \mathrm{H}_{4} \mathrm{~S} \text { (Thiophene) } \rightarrow \mathrm{SH}+\mathrm{C}_{4} \mathrm{H}_{3}
\end{aligned}
$$

The derived $\mathrm{P}\left(\mathrm{E}_{\mathrm{c.m}}\right)$ for these processes show characteristics of unimolecular decay. For process (1), two isomer products: $\bullet$ CHCHS $\bullet$ and $c-\mathrm{CH}=\mathrm{CHS}$ have been observed from TOF spectra for $\mathrm{C}_{2} \mathrm{H}_{2} \mathrm{~S}$. By observing the maximum release of translational energy, the bond energies, including bond cleavages of a primary step and a secondary step, have been determined to be $113.5 \pm 2,133.5 \pm 2$ and $138 \pm 2 \mathrm{kcal} / \mathrm{mol}$ for $c$ - $\mathrm{CH}=\mathrm{CHS}+\mathrm{HC} \equiv \mathrm{CH}$, - $\mathrm{CHCHS} \bullet+\mathrm{HC} \equiv \mathrm{CH}$ and $\mathrm{SH}+\mathrm{C}=\mathrm{CH}-\mathrm{CH}=\mathrm{CH}$, respectively, which is in agreement with the literature data. Furthermore, the isotropic angular distributions for all these processes are consistent with the fact that photodissociation processes occur via a stepwise mechanism.

\section{References}

(1) S. Braslavsky and J. Heicklen; Chemical Reviews, 77, 473 (1977).

(2) C. W. Hsu, C.-L. Liao, Z.-X. Ma, and C.Y. Ng; J. Phys. Chem. 99, 1760 (1995).

(3) Myers, J.D. Ph.D. Thesis, University of California at Berkeley (1993).

(4) H. A. Wiebe and J. Heicklen; Ca. J. Chem. 47, 2964 (1969).

(5) W.-B. Tzeng, H.-M. Yin, W.-Y. Leung, J.-Y. Luo, S. Nourbakhsh, G. D. Flesch, and C. Y. Ng, J. Chem. Phys. 88, 1658(1988).

(6) S. Nourbakhsh, C.-L. Liao, and C. Y. Ng, J. Chem. Phys. 92, 6587(1990). 
(7) T. K. Minton, G. M. Nathanson, and Y. T. Lee, J. Chem. Phys. 86, 1991(1987).

(8) E. J. Hintsa, X. Zhao, and Y. T. Lee, J. Chem. Phys. 92, 2280(1990).

(9) X. Zhao, Ph.D. thesis, University of California, Berkeley, CA, 1988.

(10) L. J. Butler, E. J. Hintsa, S. F. Shane, and Y. T. Lee, J. Chem. Phys. 86, 2051(1987).

(11) S. F. Mason, Physical Methods in Heterocyclic Chemistry, Katritzky, Academic Press, New York (1963).

(12) E. E. van Tamalen and T. H. Whitesides, J. Am. Chem. Soc., 93, 6129(1971).

(13) A. K. Nayak, S. K. Sarkar, R. S. Karve, V. Parthasarathy, K. V. S. Rama Rao, J. P. Mittal, S. L. N. G. Krishnamachari, and T. V. Venkitachalam, Appl. Phys. B 48, 437(1989). 


\title{
SCATTERING CROSS SECTIONS FOR O( $\left.{ }^{3} \mathrm{P}\right)\left[\mathrm{SO}\left(\mathrm{X},{ }^{3} \Sigma^{-}\right)\right]+\mathrm{He}[\mathrm{Ne}, \mathrm{Ar}, \mathrm{Kr}]$
}

\author{
A paper to be submitted to the Journal of Chemical Physics \\ H.-Q. Zhao and C. Y. Ng
}

\begin{abstract}
Scattering cross sections for $\mathrm{O}\left({ }^{3} \mathrm{P}\right)\left[\mathrm{SO}\left(\mathrm{X}^{3} \Sigma^{-}\right)\right]+\mathrm{He}[\mathrm{Ne}, \mathrm{Ar}, \mathrm{Kr}]$ have been measured in a photodissociation apparatus. The scattering for $\mathrm{O}\left({ }^{3} \mathrm{P}\right)+\mathrm{He}[\mathrm{Ne}, \mathrm{Ar}, \mathrm{Kr}]$ obeys the rigid sphere model inthe high velocity range. The measurements of impact parameters, $\mathrm{r}_{0}$, for the scattering of $\mathrm{O}\left({ }^{3} \mathrm{P}\right)+\mathrm{He}[\mathrm{Ne}]$ are close to the summation of van der Waals radii of the colliding particles. The measurements for $\mathrm{SO}\left(\mathrm{X}^{3} \Sigma^{-}\right)+\mathrm{He}[\mathrm{Ne}, \mathrm{Ar}, \mathrm{Kr}]$ show that the interaction potential is of the form $V(r)= \pm C_{n} / r^{n}$. Values for $C_{n}$ and $n$ were also determined.
\end{abstract}

\section{Introduction}

Measurement of elastic scattering cross sections can be used to determine the interaction potential of the colliding particles. ${ }^{12}$ Knowledge of these interactions provides information for understanding van der Waals forces and the sizes of colliding particles. Furthermore, the interactions between radicals and molecules are involved in many processes, such as UV laser action and photochemical reactions. Therefore, the knowledge of these interactions is of interest to understanding these processes.

Due to their high chemical reactivity, radicals are also involved in many reactive scattering studies. ${ }^{3,4}$ The determination of these interactions can also provide information for understanding orientation and alignment of these radicals in reactive collision. In the past years, the measurement of such interactions mainly employ thermal dissociation, microwave discharge 
or electron bombardment to produce radicals. ${ }^{5-7}$ However, due to the limitations of the method, only some of the radical states can be produced, and the experimental velocity range covers only a part of the potential energy curve. The photodissociation of molecules is another important source of radicals and can produce a pure state. Moreover, the photodissociation processes of many molecules have been studied in detail ${ }^{8-14}$. This knowledge helps us to select radicals in the desired electronic state. For example, the photodissociation processes (1) and (2) ${ }^{15,16}$

$$
\begin{aligned}
\mathrm{SO}_{2}+\mathrm{hv}(193 \mathrm{~nm}) & \rightarrow \mathrm{O}\left({ }^{3} \mathrm{P}\right)+\mathrm{SO}\left({ }^{3} \Sigma\right) \\
\mathrm{N}_{2} \mathrm{O}+\mathrm{hv}(193 \mathrm{~nm}) & \rightarrow \mathrm{O}\left({ }^{1} \mathrm{D}\right)+\mathrm{N}_{2}\left({ }^{1} \Sigma\right)
\end{aligned}
$$

can be used to study the scattering behavior of different $O$ states. In this study, we present our results using laser photodissociation to measure the scattering cross sections between $\mathrm{O}\left({ }^{3} \mathrm{P}\right)\left[\mathrm{SO}\left({ }^{3} \mathrm{~S}^{-}\right]\right.$and $\mathrm{He}[\mathrm{Ne}, \mathrm{Ar}, \mathrm{Kr})$ due to the photodissociation process (1).

\section{Experimental}

The rotatable beam source laser photofragmentation apparatus used in this study has been described in detail. ${ }^{8-14}$ The apparatus consists of three main components: an ArF or KrF excimer laser, a photodissociation chamber in which a rotatable supersonic molecular beam intersects with the laser beam, and a linearly movable ultrahigh vacuum electron ionization mass spectrometric detector.

For scattering purposes, a gas cell with a $4.45 \mathrm{~cm}$ long and $3 \mathrm{~mm}$ diameter opening was mounted at the exit of main chamber along the axis of the photodissociation and detector. In order to maintain a constant pressure throughout the experiment, a very stable leak valve (Varian model No. 951-5100) was used. Two gas lines were connected with the gas cell. One line 
connects the cylinder to the gas cell through a leak valve. The other line connects the gas cell to a baratron pressure gauge and also to a valve that leads to the main chamber. By using this design, the gas cell can be pumped down very quickly with the valve open. The gas cell pressure was maintained below $10^{-6}$ Torr with the leak valve closed, and in the $10^{-4}$ Torr range with it open. All of the rare gases used were UHP grade.

The measurement of scattering cross sections required a TOF spectrum with an attenuation due to the rare gas in the gas cell. However, the rare gas increased the background TOF signal, resulting in a large error. Therefore, a pulsed beam with lower background was used to get better results.

In this experiment, a pulsed beam of $\mathrm{SO}_{2}(20 \%$ seeded in $\mathrm{He})$ is produced by supersonic expansion through a commercial pulsed valve (General Valve, No. 9 nozzle diameter $0.5 \mathrm{~mm}$ ) at $298 \mathrm{~K}$ and a total stagnation pressure of approximately 1465 torr. The pulsed valve is operated at $50 \mathrm{~Hz}$. The seeded $\mathrm{SO}_{2}$ beam has an angular divergence of $3^{\circ}$ which is defined by the opening of the conical skimmer and the circular aperture between the differential chamber and the photodissociation chamber. The $3^{\circ}$ angular spread of the beam corresponds to a beam width of 3 $\mathrm{mm}$ in the photodissociation region. The photodissociation chambers are maintained at pressures of approximately $1 \times 10^{-8}$ torr when the leak valve is closed, and $3 \times 10^{-8}$ torr when it is open.

The laser (Questek model 2460) energy was kept constant at $70 \mathrm{~mJ}$ during the experiment, with the light focused to a roughly $5 \mathrm{~mm}^{2}$ spot size at the crossing region of the laser and molecular beams. 
The TOF spectra were taken at a flight path distance of $65.5 \mathrm{~cm}$ between the photodissociation region and the ionizer. The emission current of the ionizer was $1.60 \mathrm{~mA}$ and the ionization electron energy was $76 \mathrm{eV}$.

The TOF spectrum was recorded on a Stanford Research model SRT430 multichannel scaler. The bin widths were set to $0.32 \mathrm{~ms}$ and $0.16 \mu$ s for $\mathrm{O}\left({ }^{3} \mathrm{P}\right)$ and $\mathrm{SO}\left({ }^{3} \Sigma^{-}\right)$, respectively.

The calculation of the scattering cross section follows the general rule: ${ }^{2}$

$$
s=/ n_{k} L * \operatorname{Ln}\left(I_{0} / I\right)
$$

where $\mathrm{I}_{0}$ and $\mathrm{I}$ are the incoming and outgoing beam intensities, respectively, $\mathrm{n}_{\mathbf{k}} \mathrm{L}$ is the product of scattering gas density and length of the scattering region. Due to the gas flow of the gas cell, $\mathrm{n}_{\mathrm{k}} \mathrm{L}$ should be substituted by $\left(n_{k} L\right)_{\text {eff. }}$ The general method to calibrate this value is to use the internal standard method wherein a known scattering system in the gas pressure range is used to calibrate the value of $\left(n_{k} L\right)$. In our experiment, a second barrier with many small holes is used to introduce the rare gas into the scattering region uniformly. The gas cell exit hole is much smaller than the tube connected with the baratron, so the gas fluence is not a significant factor.

To assist the analysis of TOF data, a forward simulation method was employed ${ }^{17-19}$ The procedure involved a trial kinetic energy distribution $\mathrm{P}\left(\mathrm{E}_{\mathrm{c.m}}\right)$, which was transformed to a TOF spectrum for comparison with the experimental TOF spectrum. Here, $E_{c . m}$ was the center-of-mass kinetic energy of the photofragments. The $\mathrm{P}\left(\mathrm{E}_{\mathrm{c} . \mathrm{m}}\right)$ distribution was adjusted until satisfactory agreement between the experimental and calculated TOF data was obtained. 
The velocity distribution of the pulsed parent molecular beam, which was used in a forward simulation method, was measured after the experiments by taking the laser hole burning spectra of $\mathrm{SO}$ or $\mathrm{SO}_{2}$ at lab angle $\theta_{\mathrm{lab}}=0^{\circ}$ and using the background subtraction method. A very stable pulse generator (SRS DG535) was used to drive the experiment and the multi-channel scaler was operated in the toggle mode, which has addition and subtraction states. One of the TTL output signals of the pulse generator was used to trigger the pulsed valve controller. Another TTL output signal, delayed $450 \mu$ s from the pulsed valve firing, was divided between the trigger of the MCS and a synchronous box controlled by the toggle mode output of the MCS. Only the TTL output signal of that box was permitted to trigger the laser when the MCS was in the addition state of toggle mode. The holing burning spectrum was thus recorded. The measured speed profile of the species was then fitted to an assumed functional form: ${ }^{8}$

$$
f(v) \sim v^{2} \exp \left[-\left(v-v_{0}\right)^{2} / \alpha^{2}\right]
$$

where $V_{0}$ is the most probable speed and $\alpha$ is a measure of the width of speed profile. In this experiment, these constants were determined to be $v_{0}=9.79 \times 10^{4} \mathrm{~cm} / \mathrm{s}$ and $\alpha=0.62 \times 10^{4} \mathrm{~cm} / \mathrm{s}$, respectively. The ion drift times through the quadrupole mass filter were determined to be $4.114 \mathrm{~m}^{1 / 2} \mu \mathrm{s}$, where $\mathrm{m}$ is the ion mass. The actual flight times of photofragments were corrected for the corresponding ion drift times. 


\section{Results and Data Analysis}

\section{Scattering cross sections for $\mathbf{O}\left({ }^{3} \mathbf{P}\right)+\mathrm{He}[\mathrm{Ne}, \mathrm{Ar}, \mathrm{Kr}]$}

Scattering cross sections for $\mathrm{O}\left({ }^{3} \mathrm{P}\right)+\mathrm{He}[\mathrm{Ne}, \mathrm{Ar}, \mathrm{Kr}]$ are shown in fig. 1. Our results are in agreement with the results using a microwave discharge ${ }^{9}$, and the same rules of the scattering cross section dependence on the velocity are followed. However, due to the high velocity range in our experiment, a flat curve is observed in all of the scattering of O-He, $\mathrm{O}-\mathrm{Ne}, \mathrm{O}-\mathrm{Ar}$ and $\mathrm{O}-\mathrm{Kr}$. For the O-He system, that flat curve covers almost the entire velocity range. The fitting of the open valve TOF spectra shown in fig. 2 ( using the translational distribution of process (1) shown in fig. 3 ) are pretty good, further indicating that the scattering of $\mathrm{O}\left({ }^{3} \mathrm{P}\right)$ by $\mathrm{He}$ is uniform.

These results can be explained by the fact that in the high velocity range, the collision objects approach very close and repulsive potential energy plays an important role. Therefore, the rigid-sphere model is obeyed; ${ }^{20}$

$$
\sigma=2 \pi r_{0}^{2}
$$

where the total cross section is twice the geometrical cross section of the spheres. From Eq. 4, the value of $\mathrm{r}_{0}$ can be inferred to be $324 \mathrm{~nm}, 339 \mathrm{~nm}, 460 \mathrm{~nm}$ and $535 \mathrm{~nm}$ for O-He, O-Ne, O-Ar and $\mathrm{O}-\mathrm{Kr}$, respectively. For $\mathrm{O}-\mathrm{He}$ and $\mathrm{O}-\mathrm{Ne}$, this value is in agreement with the summation of van der Waals radii of O-He $(330 \mathrm{~nm})$ and $\mathrm{O}-\mathrm{Ne}(310 \mathrm{~nm}){ }^{21}$ respectively.

II.Scattering cross sections for $\left.\mathrm{SO}^{3} \Sigma^{-}\right)+\mathrm{He}[\mathrm{Ne}, \mathrm{Ar}, \mathrm{Kr}]$ 


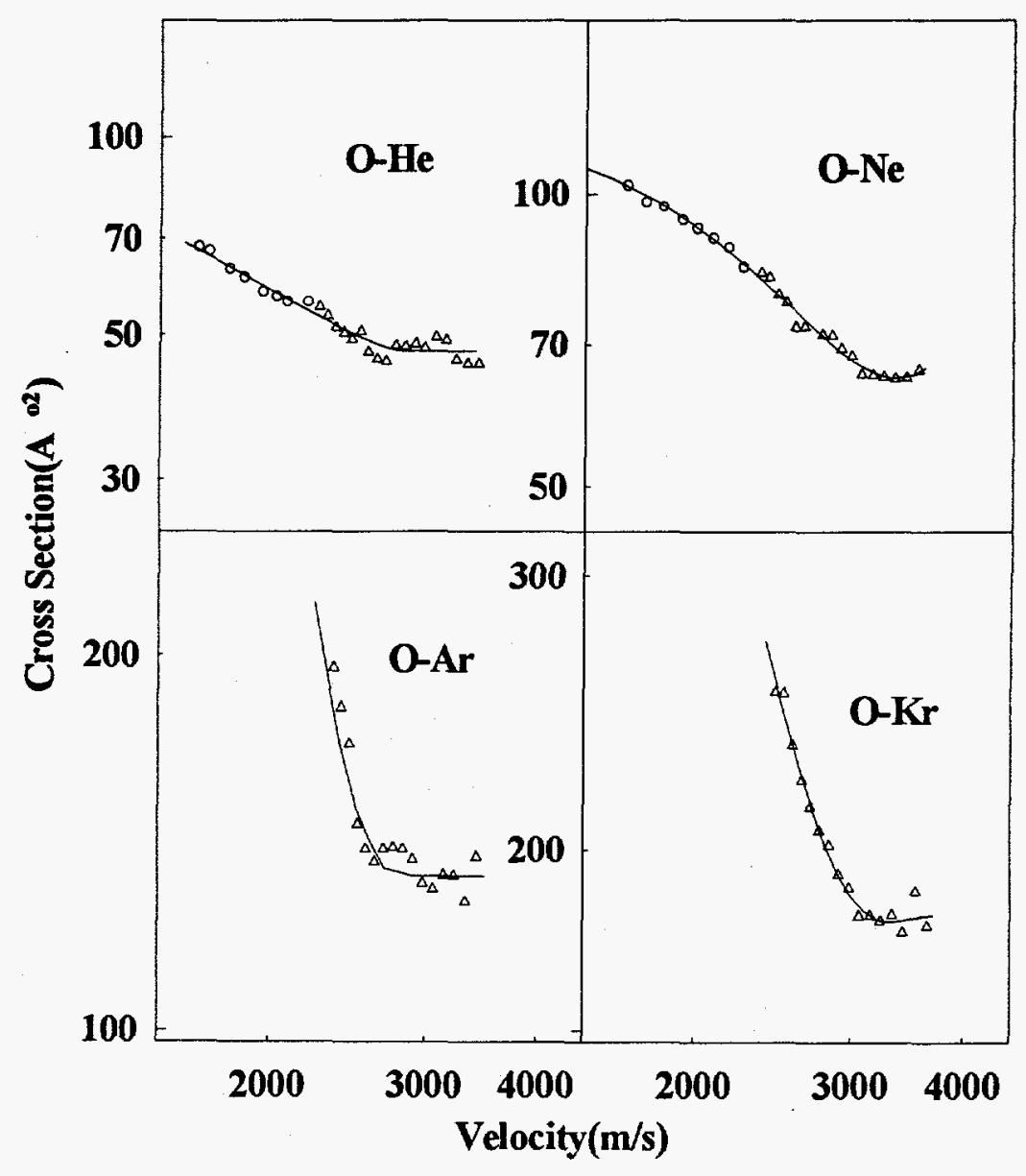

Figure 1. The scattering cross sections for $\mathrm{O}\left({ }^{3} \mathrm{P}\right)+\mathrm{He}[\mathrm{Ne}, \mathrm{Ar}, \mathrm{Kr}]$ as a function of the velocity. Circles represent the data abstracted from reference (9). 


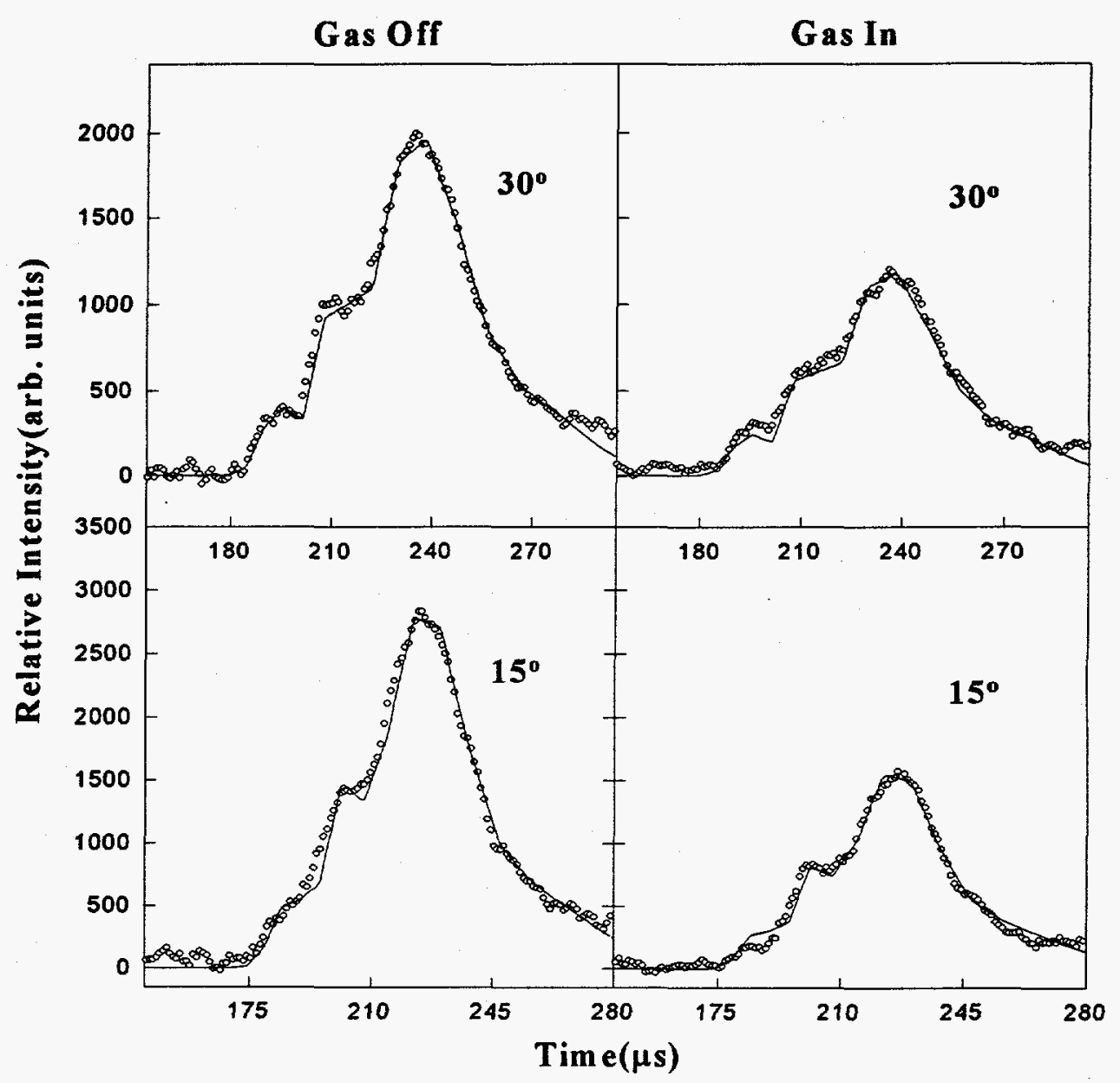

Figure 2. TOF spectra of $\mathrm{O}\left({ }^{3} \mathrm{P}\right)$ for $\mathrm{O}\left({ }^{3} \mathrm{P}\right)-\mathrm{He}$ with the leak valve closed and open. 


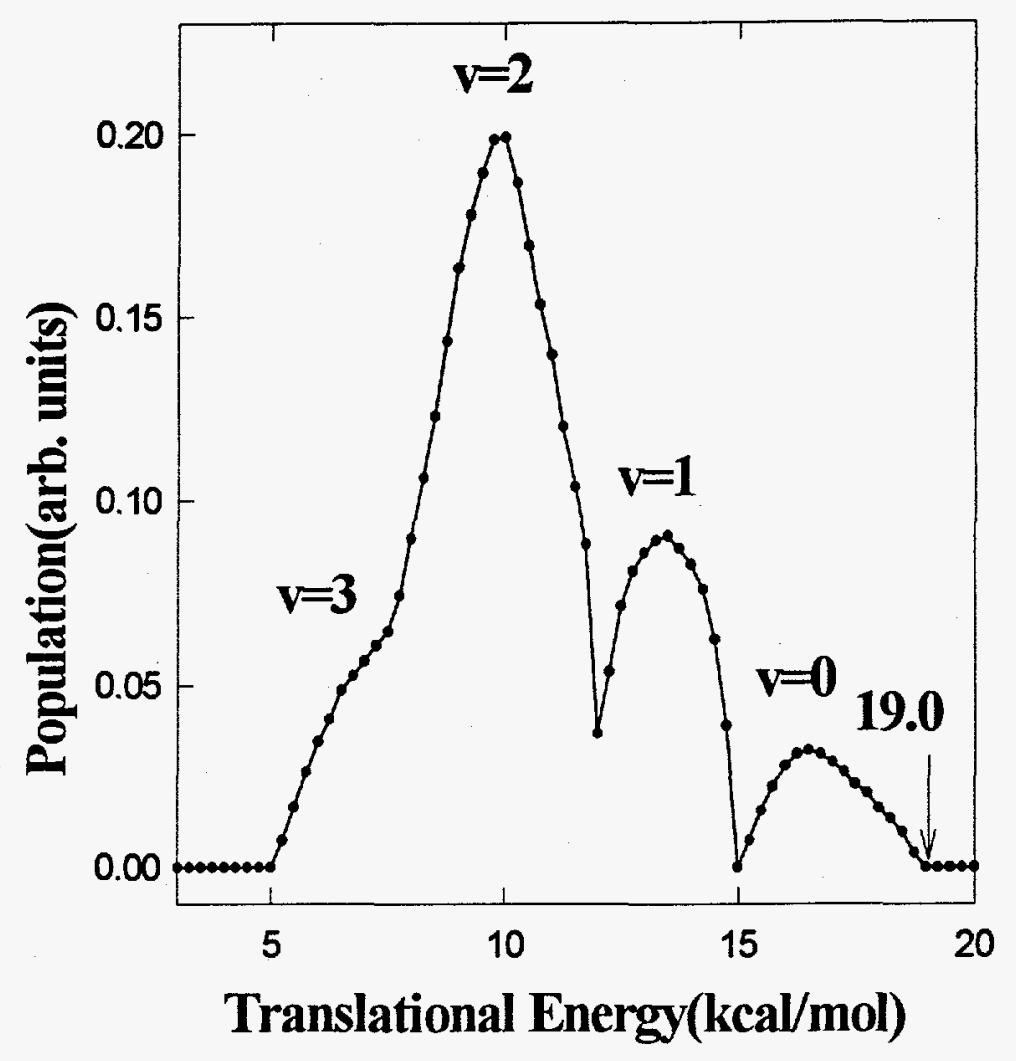

Figure 3. Translational energy of the process: $\left.\mathrm{SO}_{2}+\mathrm{hv}(193 \mathrm{~nm}) \rightarrow \mathrm{O}\left({ }^{3} \mathrm{P}\right)+\mathrm{SO}^{3}{ }^{3} \Sigma^{-}\right)$ 
Scattering cross sections for $\left.\mathrm{SO}^{3} \Sigma^{2}\right)+\mathrm{He}[\mathrm{Ne}, \mathrm{Ar}, \mathrm{Kr}]$ are shown in fig. 4. They clearly show that the $\log$ of the cross sections decreases linearly with the log of the velocity. This velocity range covers the attractive part of potential energy. However, in SO-Ar system, the repulsive part of potential energy is also observed in high velocity range. Moreover, the fitting of the TOF spectra also supports the above results. The TOF spectra (fig.5) after scattering clearly show that the SO signal is scattered more in the low velocity range $\left(\theta_{\mathrm{lbb}}=45^{\circ}\right)$ than in the high velocity range. By using the van der Waals form of potential energy:

$$
V(r)= \pm C_{n} / r^{n}
$$

the scattering cross section has the form: ${ }^{.22}$

$$
\mathrm{s}=\mathrm{F}(\mathrm{n})\left(\mathrm{C}_{\mathrm{n}} / \mathrm{hv}\right)^{2(\mathrm{n}-\mathrm{l})}
$$

where $F(n)=p^{2}\left(2 K_{n} /(n-1)\right)^{2(n-1)}\left[G(2 /(n-1) \sin (p /(n-1))]^{-1}\right.$ and $K_{n}=p^{1 / 2} G(n+1 / 2) / G(n / 2)$.

The van der Waals potential energy parameters $C_{n}$ and $r_{n}$ obtained by simulating our data (indicated by solid line of the fig.4) are given in Table 1. In the attractive portion of the potential, $\mathrm{n}$ is no more than 4 . This may due to the fact that $\mathrm{SO}$ is a polar radical. Its attractive potential is greater than that of the normal van der Waals force $(n=6)$. The repulsive part of SO-Ar has a large $n$ indicates that its repulsive potential energy rapidly increases as $r_{0}$ decreases. The interaction potential is shown in fig. 6 . 


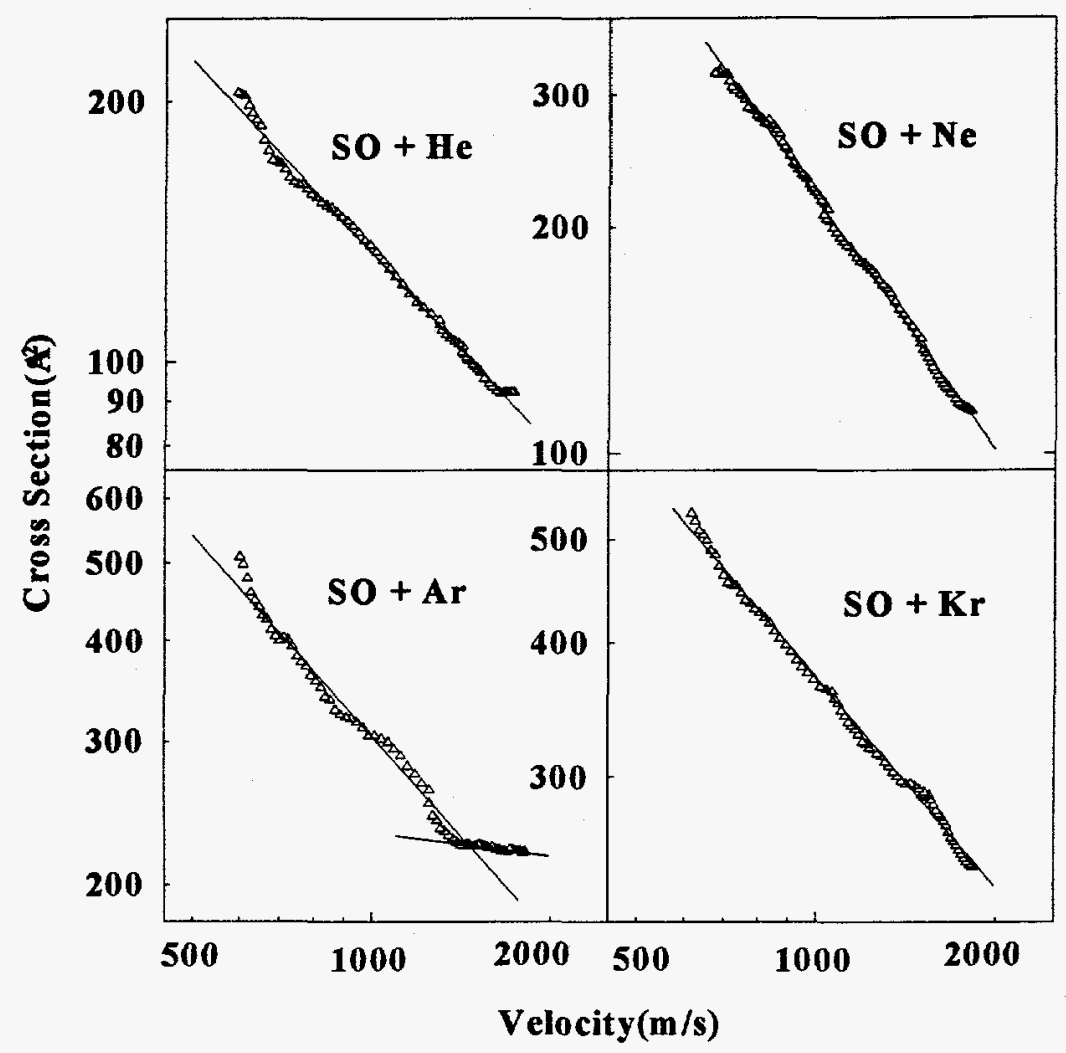

Figure 4. The scattering cross sections for $\mathrm{SO}\left({ }^{3} \mathrm{~S}\right)+\mathrm{He}[\mathrm{Ne}, \mathrm{Ar}, \mathrm{Kr}]$ as a function of the velocity. 


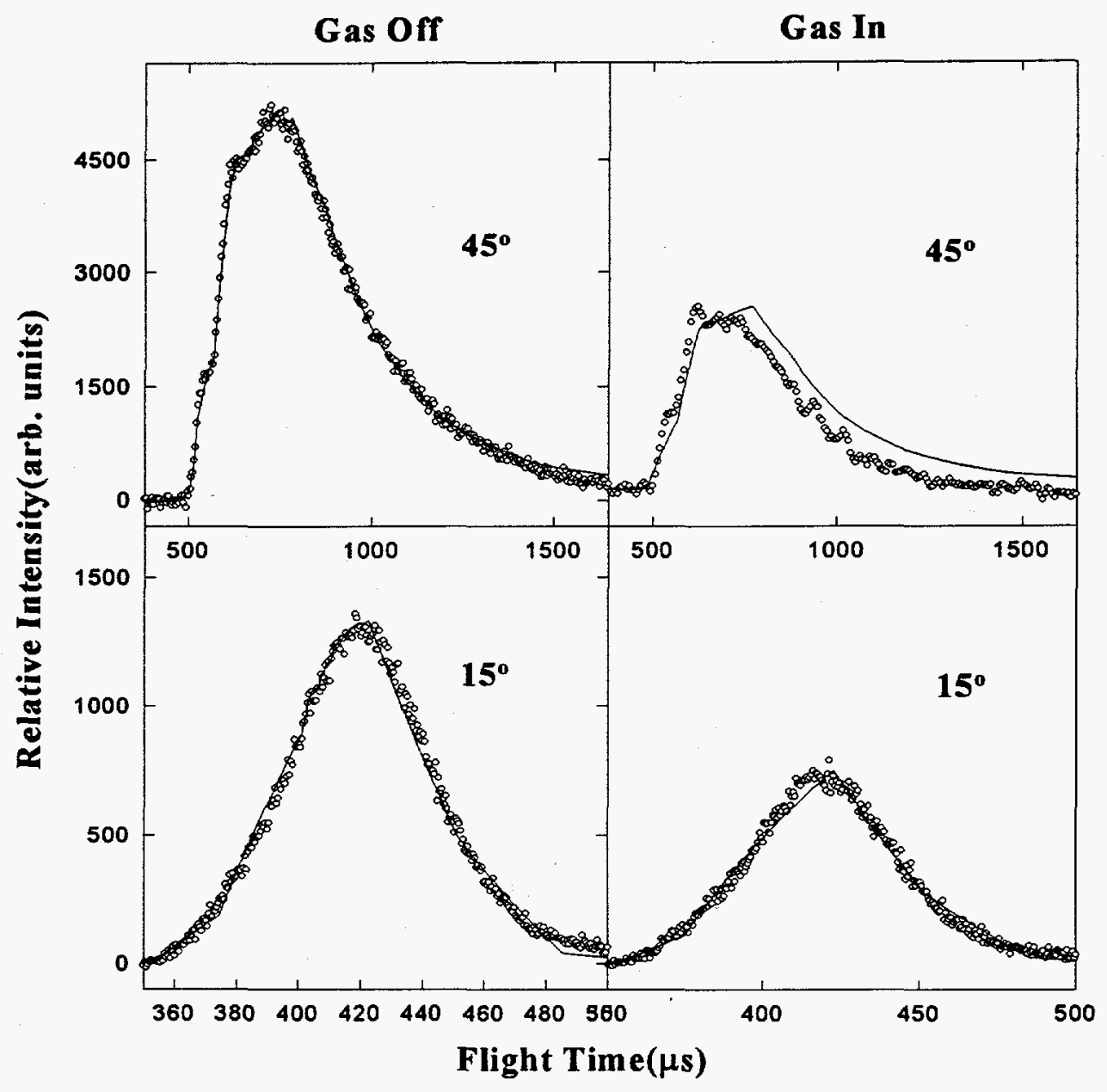

Figure 5. TOF spectra of $\left.\mathrm{SO}^{3} \Sigma^{-}\right)$for $\mathrm{SO}\left({ }^{3} \Sigma^{-}\right)$-He with leak valve closed and open. 
Table I. Potential parameters for for $\mathrm{SO}\left({ }^{3} \mathrm{~S}^{-}\right)+\mathrm{He}[\mathrm{Ne}, \mathrm{Ar}, \mathrm{Kr}]$

\begin{tabular}{|l|l|l|l|l|l|}
\hline & SO-He & SO-Ne & \multicolumn{2}{|l|}{ SO-Ar } & SO-Kr \\
\cline { 2 - 6 } & Attr. & Attr. & Attr. & Rep. & Attr. \\
\hline $\mathrm{n}$ & 3.7 & 2.8 & 3.4 & 20.8 & 4.1 \\
\hline $\mathrm{C}_{\mathrm{n}}\left(\mathrm{mevA}^{\mathrm{og}}\right)$ & 162 & 48.1 & 229 & $4.43 \mathrm{E}+16$ & 1834 \\
\hline $\mathrm{r}_{0}\left(\mathrm{~A}^{9}\right)$ Range & $3.8-5.7$ & $4.3-7.1$ & $5.9-9.0$ & & $6.3-9.2$ \\
\hline
\end{tabular}




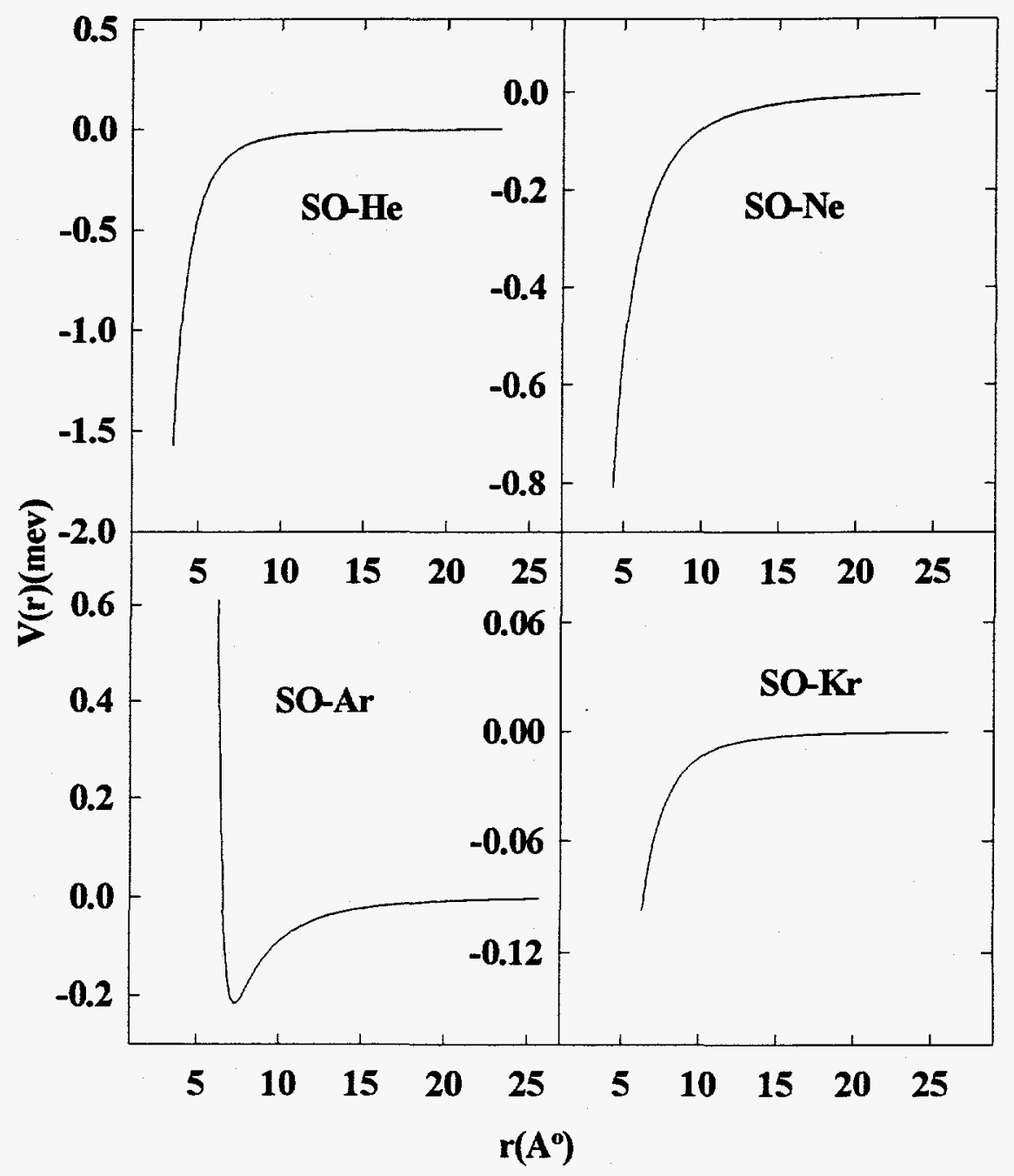

Figure 6 The interaction potential for $\left.\mathrm{SO}^{3} \Sigma^{-}\right)+\mathrm{He}[\mathrm{Ne}, \mathrm{Ar}, \mathrm{Kr}]$ at the probing distance. 


\section{Discussion}

\section{Probing Distance}

It is conventional to regard the average cross section as probing the potential at a distance of $\mathrm{r}_{0}=(\mathrm{s} / 2 \mathrm{p})^{1 / 2}$. Since the cross section is a function of velocity, a large velocity range can probe a long distance range of the interaction potential. Due to the relationship:

$$
\mathbf{V}_{\mathrm{lab}}=\mathbf{V}_{\mathrm{p}}+\mathbf{V}_{\mathrm{c} \cdot \mathrm{m}}
$$

it is evident that the lab velocity $\left(\mathrm{V}_{\mathrm{lab}}\right)$ can cover a broad range in our experiment by changing the parent velocity $\mathbf{v}_{0}$ and lab angle $\theta$, which is defined to be the angle between the seeded $\mathrm{SO}_{2}$ molecular beam and the detector axis,

Based on the energy conservation:

$h v(193)+E_{\text {int }}^{*}=D_{0}(O S-O)+E_{e}+E_{n}+E_{\tau}+E_{c . m}$

where $h v$ is the photon energy of the laser $(147.9 \mathrm{kcal} / \mathrm{mol}) ; \mathrm{E}_{\text {int }}^{*}$ is the initial internal energy of the parent $\mathrm{SO}_{2}$ molecule (assumed to be negligible due to supersonic cooling); $\mathrm{D}_{0}(\mathrm{OS}-\mathrm{O})$ is the dissociation energy for the $\mathrm{OS}-\mathrm{O}$ bond at $0 \mathrm{~K}$; and $\mathrm{E}_{\mathrm{e}}, \mathrm{E}_{\mathrm{n}}, \mathrm{E}_{\mathrm{r}}$, and $\mathrm{E}_{\mathrm{c} . \mathrm{m}}$ are the electronic, vibrational, rotational, and c.m. translational energies of the photofragments, respectively. A value of $132 \mathrm{kcal} / \mathrm{mol}$ has been given previously for the dissociation energy of the OS-O bond at 298 $\mathrm{K} .{ }^{15}$ Using this value, we have constructed a Newton diagram, shown in fig. 6 , for the formation 
of $S O$ and $O$ by process (1) using Eq. (9). Here $V_{c m}(O)$ and $V_{L a b}(O)$ represent the maximum c.m. and laboratory velocities. From the Newton diagram, the maximum $V_{c m}(O)$, which is 2 3 times $\mathrm{V}_{0}$, dominates $\mathrm{V}_{\mathrm{lbb}}(\mathrm{O})$. Therefore, the experiments have been performed over only a high velocity range for $\mathrm{O}\left({ }^{3} \mathrm{P}\right)$.

The Newton diagram for SO, which is shown in fig. 7 , is different from that for $\mathrm{O}$. It clearly shows that the beam angle has a tremendous influence on $V_{0}$ due to the small maximum $V_{c m}(S O)$. Fig. 5 shows that the TOF spectrum for $S O$ at $\theta_{\mathrm{lab}}=45^{\circ}$ covers twice the velocity range of that for $\mathrm{SO}$ at $\theta_{\mathrm{lab}}=15^{\circ}$ and goes to a slow velocity range.

It is noticed that $V_{0}$ also can be changed by changing the carrier gas. For example, in the photodissociation of $\mathrm{SO}_{2}{ }^{15}$ using $\mathrm{Ne}, \mathrm{V}_{0}$ is about 10 times smaller compared to that $\mathrm{He}$ is used. In that way, the velocity $\left(V_{l a b}\right)$ is extended to very slow velocity range, which is important for observing glory undulations.

\section{Resolution}

The resolution angle is simply given by the detector viewing angle. In our experimental setup, this angle is about one degree. This angle is limited due to the long flight distance ( gas cell center to detector distance is about $43 \mathrm{~cm}$ ) in our apparatus. In our experimental velocity range, $\vartheta$ is smaller than the limiting angle characteristic of the system. This is given by $\vartheta \sim \pi \mathrm{h} / \mu \mathrm{g}(\sigma / 2 \pi)^{-}$ ${ }^{12} .^{2}$ Since the ambient gas cell temperature is about $40{ }^{\circ} \mathrm{C}$ in our experiment. it is necessary to cool the gas cell to increase the resolution.

In summary, photodissociation processes can be used to study the interaction between radical and molecules. The radical velocity range can be extended by changing the parent molecular beam angle and carrier gas. In this study, the Scattering Cross Sections For 


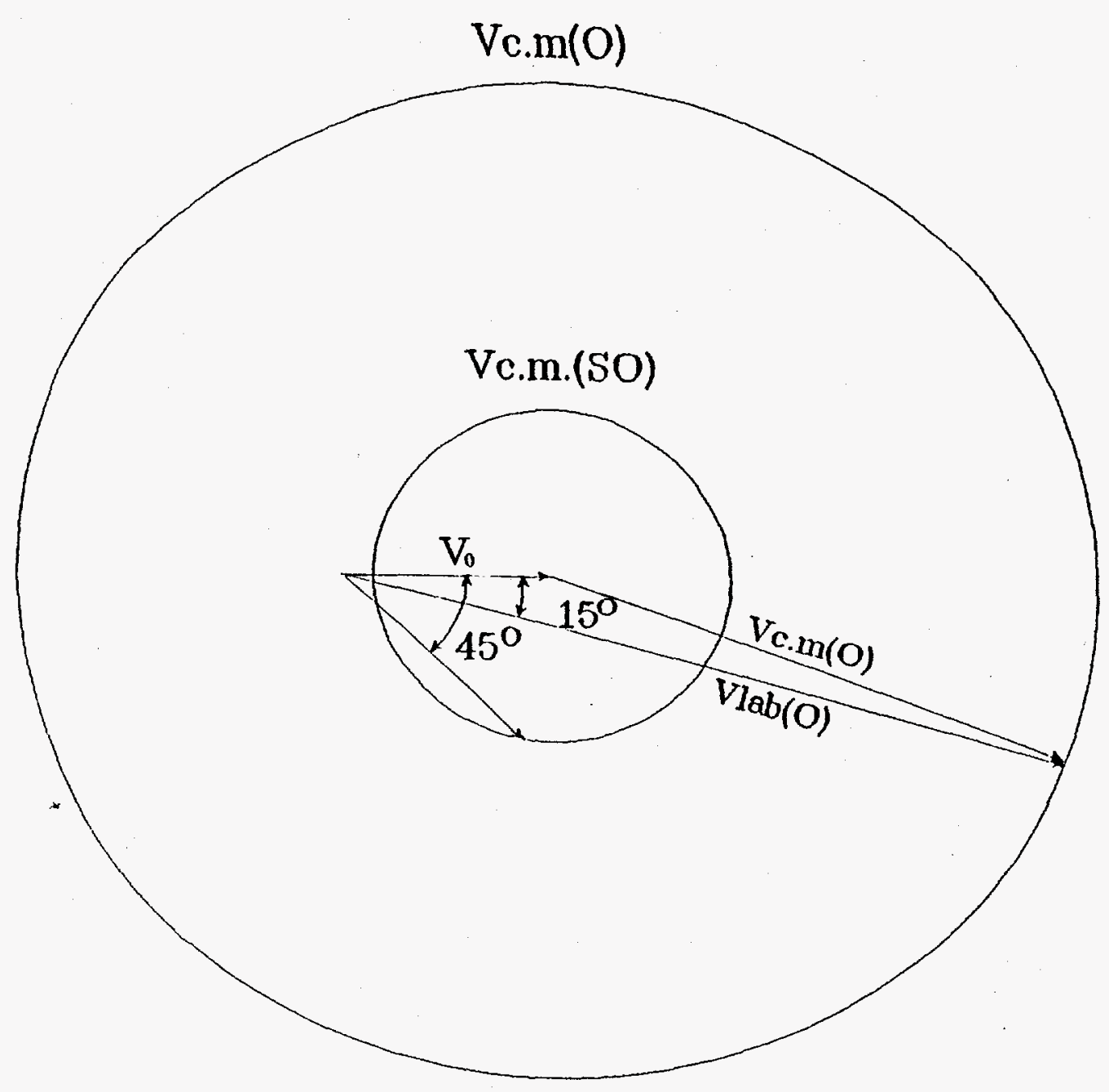

Figure 7. Kinematics for the formation of $\mathrm{SO}_{2} \rightarrow \mathrm{O}\left({ }^{3} \mathrm{P}\right)+\mathrm{SO}\left({ }^{3} \Sigma\right)$ by the $193 \mathrm{~nm}$ photodissociation of $\mathrm{SO}_{2} . \mathrm{V}_{\mathrm{p}}$ is the laboratory velocity for $\mathrm{SO}_{2} . \mathrm{V}_{\mathrm{c} . \mathrm{m}}(\mathrm{O})$ and $\mathrm{V}_{\mathrm{c} . \mathrm{m}}(\mathrm{SO})$ are the maximum c.m. velocities for $\mathrm{O}\left({ }^{3} \mathrm{P}\right)$ and $\mathrm{SO}\left({ }^{3} \Sigma^{-}\right)$, respectively. 
$\mathrm{O}\left({ }^{3} \mathrm{P}\right)\left[\mathrm{SO}\left(\mathrm{X}^{3} \Sigma^{-}\right)\right]+\mathrm{He}[\mathrm{Ne}, \mathrm{Ar}, \mathrm{Kr}]$ have been measured, and the interaction potential has been derived.

\section{Conclusion}

Scattering cross sections for $\mathrm{O}\left({ }^{3} \mathrm{P}\right)\left[\mathrm{SO}\left(\mathrm{X}^{3}{ }^{3} \Sigma^{-}\right)\right]+\mathrm{He}[\mathrm{Ne}, \mathrm{Ar}, \mathrm{Kr}]$ have been measured in photodissociation apparatus. In comparison with other methods, the scattering particles can be prepared in a pure state, but the measurement of velocity range is limited by the nature of the molecule photodissociation. The scattering for $\mathrm{O}\left({ }^{3} \mathrm{P}\right)+\mathrm{He}[\mathrm{Ne}, \mathrm{Ar}, \mathrm{Kr}]$ obeys the rigid sphere model at high velocity range. The measurement of impact parameters, $r_{0}$, for the scattering of $\mathrm{O}\left({ }^{3} \mathrm{P}\right)+\mathrm{He}[\mathrm{Ne}]$ are close to the summation of van der Waals radii of the colliding particles. The measurements for $\mathrm{SO}\left(\mathrm{X},{ }^{3} \Sigma\right)+\mathrm{He}[\mathrm{Ne}, \mathrm{Ar}, \mathrm{Kr}]$ show that the interaction potential is of the form $V(r)= \pm C_{n} / r^{n}$. Values for $C_{n}$ and $n$ are also presented.

\section{References}

(1) R. D. Levine and R. B. Berstein, Molecular reaction dynamics and chemical reactivity (Oxford, New York, 1987)

(2) G. Scoles, D. Bassi, U. Buck and D. Laine, Atomic and Molecular beam method. Vol.I (Oxford, New York, 1988)

(3) D. M. Neumark, A. M. Wodtke, G. N. Robinson, C. C. Hayden, and Y. T. Lee, J, Chem. Phys. 82, 3045(1985)

(4) D. -C Che and K. Liu, J. Chem. Phys. 103, 5164(1995).

(5) V. Aquilanti, R. Candori, and F. Pirani, J. Chem. Phys. 89, 6157(1988) 
(6) B.G.Brunetti, S. Falcinelli, E. Giaquinto, A. Sassara, M. Prieto-Mazanares and F. Vecchiocattivi, Phys. Rev. A vol. 52, (1)855.

(7) W. E. Lamb, Jr., and R. C. Retherford, Phys. Rev. 79, 549; 81, 333(1950).

(8) W. -B Tzeng, H.-M Yin, W.-Y. Leung, J.-Y. Luo, S. Nourbakhsh, G. D. Flesch, and C. Y. Ng, J. Chem. Phys. 88, 1658(1988).

(9) S. Nourbakhsh, C.-L. Liao and C. Y. Ng, J. Chem. Phys. 92, 6587(1990).

(10) S Nourbakhsh, K. Norwood, H.-M. Yin, C.-L. Liao and C. Y. Ng, J. Chem. Phys. 95, $5014(1991)$

(11) S. Nourbakhsh, K. Norwood, H.-M. Yin, C.-L. Liao, and C. Y. Ng, J. Chem. Phys. 95, 946(1991)

(12) S. Nourbakhsh, H.-M. Yin, C.-L. Liao, and C. Y. Ng, Chem. Phys. Lett. 183, 348(1991).

(13) S. Nourbakhsh, K. Norwood, G.-Z. He, and C. Y. Ng, J. Am. Chem. Soc. 113, 6311(1991).

(14) S. Nourbakhsh, H.-M. Yin, C.-L. Liao and C. Y. Ng, Chem. Phys. Lett. 190, 469(1992).

(15) P. Felder, C. S. Effenhauser, B. M. Haas and J. R. Huber, Chem. Phys. Lett. 148,417(1988).

(16) P. felder, B.-M. Haas and J. R. Huber, Chem. Phys. Lett. 186, 177(1991).

(17) E. J. Hintsa, X. Zhao, and Y. T. Lee, J. Chem. Phys. 92, 2280(1990).

18. X. Zhao, Ph.D. Thesis, University of California, Berkeley, CA(1988).

19. L. J. Butler, E. J. Hintsa, S. F. Shane, and Y. T. Lee, J. Chem. Phys. 86, 2051(1987).

20. H. S. W. Massey and C. B. O. Mohr, Proc. Roy. Soc. (LonDon) A141(1933)434.

21. L. Pauling, The nature of the chemical bond(Ithaca, New York)(1960).

22. E.A. Mason, and V. D. Maijdenberg, Physica 117A, 139. 


\section{GENERAL CONCLUSION}

Photodissociation dynamics of polyatomic molecules for $\mathrm{C}_{6} \mathrm{H}_{5} \mathrm{COCH}_{3},\left(\mathrm{CH}_{3}\right)_{2} \mathrm{SO}$, $\mathrm{HSCH}_{2} \mathrm{CH}_{2} \mathrm{SH}$, and $\mathrm{C}_{4} \mathrm{H}_{4} \mathrm{~S}$ (Thiophene) have been studied by using photofragment translational spectroscopy. The TOF spectra for $\mathrm{CH}_{3}$ and $\mathrm{C}_{6} \mathrm{H}_{5}$ resulting from photofragmentation of $\mathrm{C}_{6} \mathrm{H}_{5} \mathrm{COCH}_{3}$ show that the branching ratio of $\mathrm{C}_{6} \mathrm{H}_{5}+\mathrm{COCH}_{3}$ to $\mathrm{C}_{6} \mathrm{H}_{5} \mathrm{CO}$ $+\mathrm{CH}_{3}$ is $\approx 1$ for $193 \mathrm{~nm}$ excitation, but that ratio decreases to $\approx 0.01$ at $248 \mathrm{~nm}$ excitation, The secondary dissociation, $\mathrm{C}_{6} \mathrm{H}_{5} \mathrm{CO}^{*} \rightarrow \mathrm{C}_{6} \mathrm{H}_{5}+\mathrm{CO}$ and $\mathrm{CH}_{3} \mathrm{CO}^{*} \rightarrow \mathrm{CH}_{3}+\mathrm{CO}$, is only observed at $193 \mathrm{~nm}$ excitation. However, the minor process, $\mathrm{CH}_{3} \mathrm{COC}_{6} \mathrm{H}_{5} \rightarrow \mathrm{CH}_{3} \mathrm{C}_{6} \mathrm{H}_{5}+\mathrm{CO}$, is detected at both $193 \mathrm{~nm}$ and $248 \mathrm{~nm}$ excitation. The maximum release of translational energy for process $\mathrm{CH}_{3} \mathrm{COC}_{6} \mathrm{H}_{5} \rightarrow \mathrm{C}_{6} \mathrm{H}_{5} \mathrm{CO}+\mathrm{CH}_{3}$ at $248 \mathrm{~nm}$ indicates that the $\mathrm{C}_{6} \mathrm{H}_{5} \mathrm{CO}-\mathrm{CH}_{3}$ bond energy is $80.2 \pm$ $3 \mathrm{kcal} / \mathrm{mol}$. The product processes resulting from the $193.3 \mathrm{~nm}$ photofragmentation of $\left(\mathrm{CH}_{3}\right)_{2} \mathrm{SO}$ show that $\mathrm{CH}_{3} \mathrm{SO}, \mathrm{CH}_{3}$ and $\mathrm{SO}$ are the dominant photoproducts. The $\mathrm{E}_{\mathrm{c} \text {.m. }}$ energy distribution for photofragments of $\left(\mathrm{CH}_{3}\right)_{2} \mathrm{SO} \rightarrow \mathrm{CH}_{3}+\mathrm{CH}_{3} \mathrm{SO}$ peaks at $\mathrm{E}_{\text {c.m. }} \approx 3$ $\mathrm{kcal} / \mathrm{mol}$, indicating that $\mathrm{CH}_{3} \mathrm{SO}$ and $\mathrm{CH}_{3}$ are formed with considerable internal energies. Data analysis suggests that $\approx 53 \%$ of the $\mathrm{CH}_{3} \mathrm{SO}$ radicals initially formed by process $\left(\mathrm{CH}_{3}\right)_{2} \mathrm{SO} \rightarrow \mathrm{CH}_{3}+\mathrm{CH}_{3} \mathrm{SO}$ at $193 \mathrm{~nm}$ excitation undergo spontaneous dissociation to $\mathrm{CH}_{3}$ $+\mathrm{SO}$, with a quantum yield of $\approx 1.53$ for $\mathrm{CH}_{3}$. The product processes resulting from the 193 nm photofragmentation of $\mathrm{HSCH}_{2} \mathrm{CH}_{2} \mathrm{SH}$ have shown that the C-S scission to yield $\mathrm{SH}+$ $\mathrm{CH}_{2} \mathrm{CH}_{2} \mathrm{SH}$ constitutes the overwhelmingly dominant product process. On the basis of the $\mathrm{E}_{\mathrm{c} . \mathrm{m}}$ threshold for the $\mathrm{P}\left(\mathrm{E}_{\mathrm{c} . \mathrm{m}}\right)$ distribution of $\mathrm{HS}+\mathrm{CH}_{2} \mathrm{CH}_{2} \mathrm{SH}$, we obtain a value of $74 \pm 2$ $\mathrm{kcal} / \mathrm{mol}$ for $\mathrm{D}_{0}\left(\mathrm{HS}-\mathrm{CH}_{2} \mathrm{CH}_{2} \mathrm{SH}\right)$. The angular distribution measurements of $\mathrm{SH}$ gives $\beta=-$ 
$0.4 \pm 0.1$ for process: $\mathrm{HSCH}_{2} \mathrm{CH}_{2} \mathrm{SH} \rightarrow \mathrm{HS}+\mathrm{CH}_{2} \mathrm{CH}_{2} \mathrm{SH}$, indicating that the $\mathrm{C}-\mathrm{S}$ bond fission is fast with respect to molecular rotation. Photodissociation of thiophene, a cyclic organic compound, revealed different pathways of transient biradical decay by breakage of different bonds. Five dissociation processes have been identified as follows:

$$
\begin{aligned}
& \mathrm{C}_{4} \mathrm{H}_{4} \mathrm{~S} \text { (Thiophene) } \rightarrow \mathrm{HC} \equiv \mathrm{CH}+\mathrm{C}_{2} \mathrm{H}_{2} \mathrm{~S} \\
& \mathrm{C}_{4} \mathrm{H}_{4} \mathrm{~S} \text { (Thiophene) } \rightarrow \mathrm{S}+\mathrm{C}_{4} \mathrm{H}_{4} \\
& \mathrm{C}_{4} \mathrm{H}_{4} \mathrm{~S} \text { (Thiophene) } \rightarrow \mathrm{C}_{3} \mathrm{H}_{3}+\mathrm{HCS} \\
& \mathrm{C}_{4} \mathrm{H}_{4} \mathrm{~S} \text { (Thiophene) } \rightarrow \mathrm{CS}+\mathrm{C}_{3} \mathrm{H}_{4} \\
& \mathrm{C}_{4} \mathrm{H}_{4} \mathrm{~S} \text { (Thiophene) } \rightarrow \mathrm{SH}+\mathrm{C}_{4} \mathrm{H}_{3}
\end{aligned}
$$

The derived $\mathrm{P}\left(\mathrm{E}_{\mathrm{c} . \mathrm{m}}\right)$ for these processes shows characteristics of unimolecular decay. For process (1), two isomer products: $\bullet$ CHCHS $\bullet$ and $c$ - $\mathrm{CH}=\mathrm{CHS}$ are observed from TOF spectra for $\mathrm{C}_{2} \mathrm{H}_{2} \mathrm{~S}$. By observing the maximum release of translational energy, the bond energies, including bond cleavages of a primary step and a secondary step, have been determined to be $113.5 \pm 2,133.5 \pm 2$ and $138 \pm 2 \mathrm{kcal} / \mathrm{mol}$ for $c-\mathrm{CH}=\mathrm{CHS}+\mathrm{HC} \equiv \mathrm{CH}$, $-\mathrm{CHCHS} \bullet+\mathrm{HC} \equiv \mathrm{CH}$, and $\mathrm{SH}+\mathrm{C}=\mathrm{CH}-\mathrm{CH}=\mathrm{CH}$, respectively, which is in agreement with literature data. Furthermore, the isotropic angular distribution for all of these processes is consistent with the fact that photodissociation processes occur via a stepwise mechanism.

Scattering cross sections for $\mathrm{O}\left({ }^{3} \mathrm{P}\right)\left[\mathrm{SO}\left(\mathrm{X}^{3} \Sigma^{-}\right)\right]+\mathrm{He}[\mathrm{Ne}, \mathrm{Ar}, \mathrm{Kr}]$ have been measured in the modified photofragment translational spectroscopy apparatus. In comparison with other 
methods, the scattering particles can be prepared in a pure state, but measurement of the velocity range is limited by the nature of the molecule photodissociation.. The scattering for $\mathrm{O}\left({ }^{3} \mathrm{P}\right)+$ $\mathrm{He}[\mathrm{Ne}, \mathrm{Ar}, \mathrm{Kr}]$ obeys the rigid sphere model at high velocity range. The measurements of impact parameters, $\mathrm{r}_{0}$, for the scattering of $\mathrm{O}\left({ }^{3} \mathrm{P}\right)+\mathrm{He}[\mathrm{Ne}]$ are close to the summation of van der Waals radii of the colliding particles. The measurements for $\mathrm{SO}\left(\mathrm{X}^{3} \Sigma^{-}\right)+\mathrm{He}[\mathrm{Ne}, \mathrm{Ar}, \mathrm{Kr}]$ show that the interaction potential is of the form $V(r)= \pm C_{n} / r^{n}$. Values for $C_{n}$ and $n$ have also been determined. 